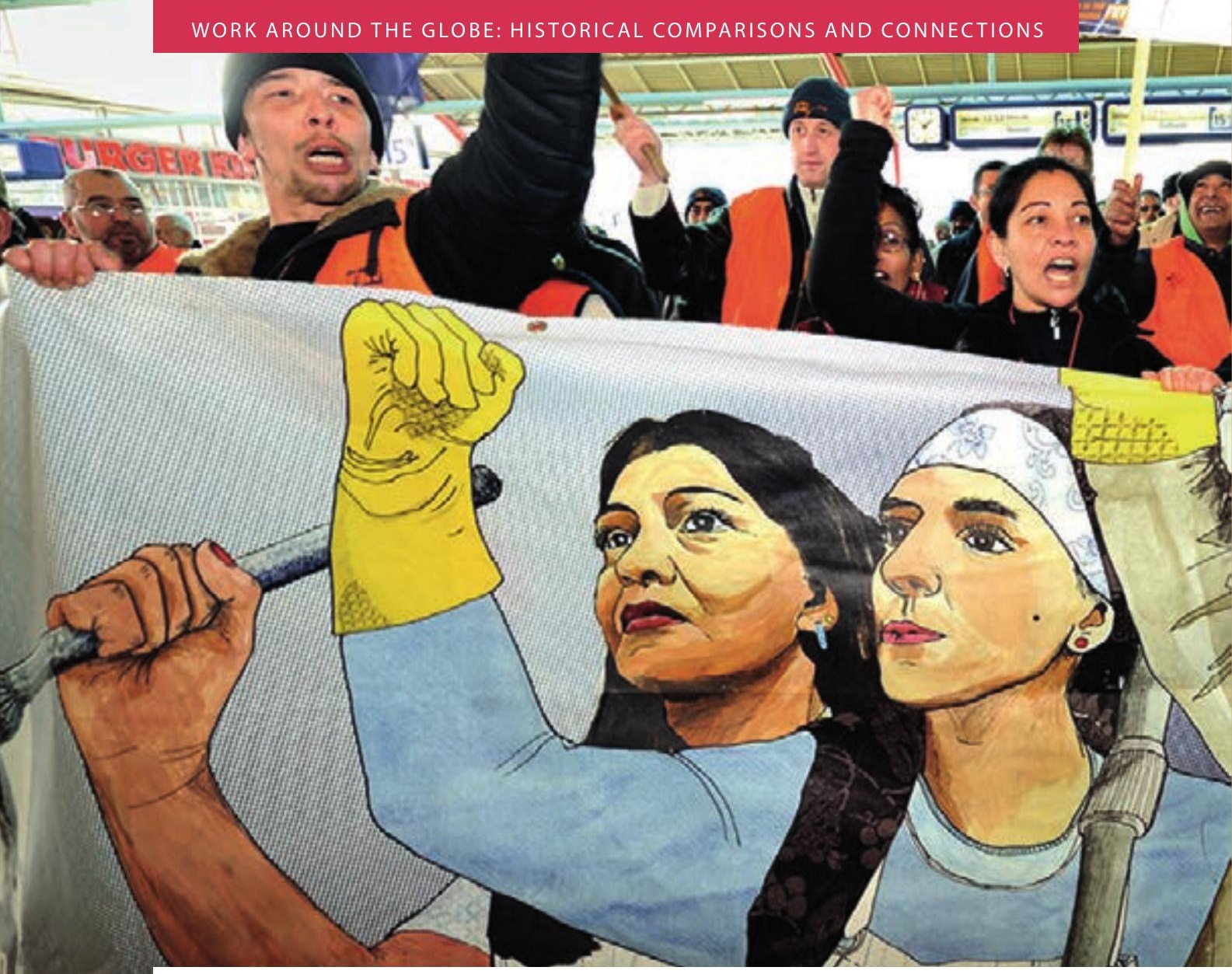

Ad Knotter

\title{
Transformations of Trade Unionism
}

Comparative and Transnational

Perspectives on Workers Organizing in Europe and the United States,

Eighteenth to Twenty-First Centuries 
Transformations of Trade Unionism 


\title{
Work Around the Globe: Historical Comparisons and Connections
}

\author{
Open Access Book Series of the International Institute \\ of Social History (IISH)
}

Most human beings work, and growing numbers are exposed to labour markets. These markets are increasingly globally competitive and cause both capital and labour to move around the world. In search of the cheapest labour, industries and service-based enterprises move from West to East and South, but also, for example, westwards from China's east coast. People move from areas with few employment opportunities to urban and industrial hubs, both between and within continents. However, labour relations have been shifting already for centuries, labour migrations go back far in time, and changing labour relations cannot be comprehended without history. Therefore, understanding these developments and their consequences in the world of work and labour relations requires sound historical research, based on the experiences of different groups of workers in different parts of the world at different moments in time, throughout human history.

The research and publications department of the International Institute of Social History (IISH) has taken on a leading role in research and publishing on the global history of labour relations. In the context of Global Labour History, three central research questions have been defined: (1) What labour relations have emerged in parallel with the rise and advance of market economies? (2) How can their incidence (and consequently the transition from one labour relation to another) be explained, and are these worldwide transitions interlinked? (3) What are the social, economic, political, and cultural consequences of their changing incidence, and how do they relate to forms of individual and collective agency among workers? These three questions are interconnected in time, but also in space. Recent comparative Global Labour History research demonstrates that shifts in one part of the globe have always been linked to shifts in other parts.

Series Editor: Leo Lucassen, International Institute of Social History, Amsterdam Editorial Board: Ulbe Bosma, Karin Hofmeester, Marcel van der Linden, International Institute of Social History, Amsterdam Executive Editor: Aad Blok, International Institute of Social History, Amsterdam 


\section{Transformations of Trade Unionism}

Comparative and Transnational Perspectives on Workers Organizing in Europe and the United States, Eighteenth to Twenty-First Centuries

Ad Knotter 
Cover illustration: March by some 400 cleaners during a sit-in at Utrecht Central Station, 16 March 2010

(C) Photograph by Rob Nelisse; used with permission

Cover design: Coördesign, Leiden

Lay-out: Crius Group, Hulshout

$\begin{array}{ll}\text { ISBN } & 9789463724715 \\ \text { e-ISBN } & 9789048544486 \text { (pdf) } \\ \text { DOI } & 10.5117 / 9789463724715 \\ \text { NUR } & 696\end{array}$

\section{(c) $(1) \Theta \Theta$}

Creative Commons License CC BY NC ND (http://creativecommons.org/licenses/by-nc-nd/3.o)

(c) Ad Knotter / Amsterdam University Press B.V., Amsterdam 2018

Some rights reserved. Without limiting the rights under copyright reserved above, any part of this book may be reproduced, stored in or introduced into a retrieval system, or transmitted, in any form or by any means (electronic, mechanical, photocopying, recording or otherwise). 


\section{Table of Contents}

$\begin{array}{lr}\text { Abbreviations } & 9\end{array}$

Introduction 11

1 An international of insolence $\quad 35$

The great anger of the cloth shearers in north-western Europe in the eighteenth century

2 Transnational cigar-makers

Cross-border labour markets, strikes, and solidarity at the time of the First International (1864-1873)

3 From artisanal associations to collective bargaining agents

Two phases of early trade unionism in Amsterdam (1864-1894)

4 Trade unions and workplace organization

Regulating labour markets in the Belgian and American flat-glass industry and in the Amsterdam diamond industry (c. 1880-1940)

5 From placement control to control of the unemployed 167 Trade unions and labour market intermediation in western Europe in the nineteenth and early twentieth centuries

6 The transnational origins of Dutch miners' unionism A case study in the nationalization of labour movements (1907-1926)

7 Justice for Janitors goes Dutch Precarious labour and trade union response in the cleaning industry (1988-2012): a transnational history

Conclusion: Past and future transformations 


\section{List of figures, tables and appendices}

\section{Figures}

Figure 1.1 Map of the territorial borders in the area between Aachen and Liège in the eighteenth century

Figure 1.2 Bronze statuette representing a cloth shearer adorning the top of the Weberbrunnen fountain in Monschau

Figure 1.3 Cloth shearers in a workshop. Engraving by J.G. van Vliet, Leiden, 1635

Figure 1.4 Cloth shearers working with a crook or mailloche in their right hands. Engraving, France, seventeenth century

Figure 1.5 Map of the centres of cloth production in Northwestern Europe and years of strike actions between 1588 and 1830

Figure 2.1 Julius Bruhns (Hamburg 1860-Offenbach 1927)

Figure 2.2 Interior of a cigar factory in Havana, Cuba, c. 1903

Figure 2.3 Friedrich Wilhelm Fritsche (Leipzig 1825-Philadelphia 1905)

Figure 3.1 Carpenters at the construction of the Paleis voor Volksvlijt (Palace of People's Industry), Amsterdam, c. 1862

Figure 3.2 Boys labour in the Senefelder printing works, Amsterdam, c. 1900

Figure 4.1 Cutting glass-cylinders in a Belgian window-glass factory

Figure 4.2 Interior of the window-glass factory Verreries du Centre in Jumet, Belgium, date unknown $\quad 140$

Figure 4.3 Banner of L'Union Verrière Belge, $1894 \quad 149$

Figure 4.4 Glass-blowers and-cutters on strike, date unknown $\quad 150$

Figure 4.5 The main operations of diamond processing: splitting, cutting, polishing, c. 1880

Figure 6.1 Postcard issued by the German miners' union Alte Verband, date unknown

Figure 6.2 Map of the sub-districts of the South-Limburg mining region and the location of the mines

Figure 6.3 Membership development of смв and АNMB, 19071930 (31 December)

Figure 6.4 By-laws of the Christelijke Mijnwerkersbond, 1914 
Figure 7.1 Film poster of Bread \& Roses, the film about Justice for Janitors (J4J) in Los Angeles by Ken Loach, produced by Rebecca O’Brien, and written by Paul Laverty (2000)

Figure 7.2 Downtown rally by Justice for Janitors in Los Angeles, 1990

Figure 7.3 Meeting of the 'Cleaners' Parliament' in the Amsterdam Town Hall, 12 December 2009

Figure 7.4 March by some 400 cleaners during a sit-in at Utrecht Central Station, 16 March 2010

Tables

Table 1.1

Reported meetings and strikes of cloth shearers in Amsterdam and Leiden, seventeenth-eighteenth centuries

Table 1.2 Number of cloth shearers in industrial centres in the Meuse-Rhine region, around 1800

Table 1.3 Shearers' strikes in Sedan and in the Meuse-Rhine borderlands in the eighteenth century

Table 3.1 Membership of the Amsterdam carpenters' unions Concordia Inter Nos (1868-1893) and Door Eendracht Verbetering (1885-1893)

Table 3.2 Place of birth of board members and militants active in unions in the building trades and construction workers in the SD League not known as union members, 1873-1894

Table 3.3 Year of birth of board members and militants active in unions in the building trades and construction workers in the sD League not known as union members, 1873-1894

Table 3.4 Year of arrival of board members and militants born outside Amsterdam active in the socialist unions in the building trades, and of construction workers in the sD League not known as union members, 1885-1894

Table 3.5 Province of birth of board members and militants born outside Amsterdam active in the socialist unions in the building trades, and of construction workers in the sD League not known as union members, 1885-1894 
Table 3.6 Membership of the Amsterdam branch of the Algemeene Nederlandsche Typografen Bond, 1866-1869 and 1889-1895

Table 3.7 Year of birth of board members of the Amsterdam branch of the Algemeene Nederlandse Typographen Bond and in the typographical societies De Nederlandsche Drukpers and Voorzorg en Genoegen (affiliated to the ANWV), before and after 1889

Table 3.8 Age structure of active members of the Social Democratic League and the ANwv before and after 1885 (percentages)

Table 6.1 Membership of the смв in 1915 (31 December) and the ANMB in 1916 (31 December), and gross monthly membership growth of the ANMB in 1913 in the subdistricts of the Limburg mining district, compared to the number of miners living there (density) in 1909 211

Table 6.2 Membership and net membership growth of the ANMB in the sub-districts of the Limburg mining district, 1 January-1 April 1917 220

Table 6.3 Membership growth of the смв (net) and the АNмв (gross) in the towns and villages in sub-districts of the Limburg mining district, 1918

Table 7.1 The five largest cleaning companies in the Netherlands, 2011

Appendices

Appendix 1.1 Regulations against shearers' collective actions

Appendix 6.1 Map of dwelling places of miners mentioned in Chapter 6

Appendix 6.2 Membership of CMB (1915) and ANMB (1916), gross monthly growth of ANMB (1913), miners living in the Limburg mining district (1909), and workmen's train fares issued in 1911

Appendix 7.1 Meetings, pickets, and manifestations in preparation and during the 2010 strike 


\section{Abbreviations}

\begin{tabular}{|c|c|}
\hline $\mathrm{ABM}$ & American Building Maintenance (United States) \\
\hline ABN AMRO & $\begin{array}{l}\text { Algemene Bank Nederland-Amsterdam Rotterdam } \\
\text { Bank (Netherlands) }\end{array}$ \\
\hline AFL & American Federation of Labor (USA) \\
\hline AMF & $\begin{array}{l}\text { Algemeen Mijnwerkers Fonds (General Miners' } \\
\text { Fund) (Netherlands) }\end{array}$ \\
\hline ANDB & $\begin{array}{l}\text { Algemeene Nederlandsche Diamantbewerkers Bond } \\
\text { (General Diamond Workers' Union) (Netherlands) }\end{array}$ \\
\hline ANMB & $\begin{array}{l}\text { Algemeene Nederlandsche Mijnwerkersbond } \\
\text { (General Dutch Miners' Union) (Netherlands) }\end{array}$ \\
\hline ANTB & $\begin{array}{l}\text { Algemeene Nederlandsche Timmerlieden Bond } \\
\text { (General Dutch Carpenters' Union) (Netherlands) }\end{array}$ \\
\hline ANTB & $\begin{array}{l}\text { Algemeene Nederlandsche Typographen Bond } \\
\text { (General Dutch Union of Typographers) (Netherlands) }\end{array}$ \\
\hline ANWV & $\begin{array}{l}\text { Algemeen Nederlands Werklieden Verbond (General } \\
\text { Dutch Workers' Union) (Netherlands) }\end{array}$ \\
\hline BARSORI & Bargaining for Social Rights (EU-funded research project) \\
\hline BARSORIS & $\begin{array}{l}\text { Bargaining for Social Rights at a Sectoral Level } \\
\text { (EU-funded research project) }\end{array}$ \\
\hline CIO & Congress of Industrial Organizations (United States) \\
\hline СМВ & $\begin{array}{l}\text { Christelijke Mijnwerkersbond (Christian Miners' } \\
\text { Union; short form of Algemeene Bond van Christe- } \\
\text { lijke Mijnwerkers in Nederland) (Netherlands) }\end{array}$ \\
\hline CMIU & Cigar Makers' International Union \\
\hline CNRS & Centre national de la recherche scientifique (France) \\
\hline CSU & Cleaning Services Uden (Netherlands) \\
\hline FNV & Federatie Nederlandse Vakbeweging \\
\hline IFSDRW & international Federation of Ship, Dock, and River Workers \\
\hline ILO & International Labour Organization \\
\hline ILU & International Labour Union \\
\hline ISS & International Service Systems \\
\hline ITF & International Transport Federation \\
\hline $\mathrm{J} 4 \mathrm{~J}$ & Justice for Janitors (United States) \\
\hline LA 300 & Local Assembly 300 (United States) \\
\hline LHMU & Liquor Hospitality and Miscellaneous Union (Australia) \\
\hline MAA & Municipal Archives Amsterdam (Netherlands) \\
\hline MEGA & Karl Marx Friedrich Engels Gesamtausgabe \\
\hline
\end{tabular}


NAS Nationaal Arbeids Secretariaat (National Secretariat of Labour) (Netherlands)

NS Nederlandse Spoorwegen (Dutch Railways) (Netherlands)

NVV Nederlandsch Verbond van Vakvereenigingen (Dutch Federation of Trade Unions) (Netherlands)

R\&D Research and Development

SDB Sociaal Democratische Bond (Social Democratic League) (Netherlands)

SDV Sociaal Democratische Vereniging (Social Democratic Union) (Netherlands)

SEIU Service Employees International Union (United States)

SFWU Service and Food Workers Union (New Zealand)

TGWU Transport \& General Workers Union (United Kingdom)

UNI Union Network International (now UNI Global Union)

UWV Uitvoeringsinstituut Werknemersverzekeringen

(Netherlands)

VU Vrije Universiteit Amsterdam (Free University

Amsterdam) (Netherlands) 


\title{
Introduction
}

\begin{abstract}
The introduction explores the main theoretical positions taken in this book. Contrary to twentieth-century neoliberal or nineteenth-century wage fund theories, it starts from the assumption that trade unions are a necessary and integral part of the functioning of labour markets in societies based on wage labour. The case studies all depart from the concept of labour market control as the basic goal of union behaviour. As trade unions are 'the necessary instrumentability' (J.S. Mill) of wage labour markets, it is to be expected that they will arise whenever such a market is formed. This does not mean that through time workers organized uniformly, or that there was a continuous evolution from one form of trade unionism to another. A central argument in this book is that the regulatory function of trade unions was linked to and to a great extent determined by the way production was organized. In the three centuries covered in this book, labour relations changed fundamentally, and this was reflected in different forms of trade unionism. The chapters highlight the varieties and transformations of trade unionism from a comparative and transnational perspective. They all start from Dutch examples, or incorporate a Dutch element, but the comparative and transnational approach connects these histories to general developments in Europe and the United States (the original heartlands of trade unionism) from the eighteenth century to the twenty-first.
\end{abstract}

Keywords: trade unionism, labour market control, labour regimes, industrial relations, transnationalism, internationalism

Born in 1952, I belong to the generation of labour historians who as university students had the privilege of participating in the great social upheaval of the late 1960 s and the early 1970s. Coinciding with the apogee or 'high tide' of

Knotter, Ad, Transformations of Trade Unionism: Comparative and Transnational Perspectives on Workers Organizing in Europe and the United States, Eighteenth to Twenty-First Centuries. Amsterdam, Amsterdam University Press, 2018 DOI: $10.5117 / 9789463724715$ INTRO 
trade unionism, ${ }^{1}$ working-class organizations seemed to be potential allies in the struggle for social justice and the politics of social change. Rank-and-file militancy boosted industrial action and drove up membership figures. ${ }^{2}$ Like so many of my generation, as a student I developed an interest in the history of trade unions as mass labour movements. While the waning of the 1960 s/1970s cycle of protest, the fall in union membership and density in many countries, and the growing ideological impact of neoliberalism may have caused trade unions to become less pre-eminent in their original heartlands in Europe and the United States, both as a social force and as an object of historical research, my interest in trade union history continued to exist and even revived when the 'transnational turn' in labour history opened new perspectives of research. ${ }^{3}$

Trade unions have historically been, and will be in the future, indispensable to protect workers against the vagaries of the so-called free market. There can be no doubt that the weakening of union density and power was one of the main causes of the steady decline of the wage share in advanced capitalist countries since the $1970 \mathrm{os} / 1980 \mathrm{~s} .{ }^{4}$ In the future, a revival of trade union militancy and mobilizing power - in whatever form or configuration - would be crucial for this tendency to be reversed. From this perspective it would be unwarranted, in my opinion, to dismiss trade unions because they are pursuing 'narrow economic interests', as opposed

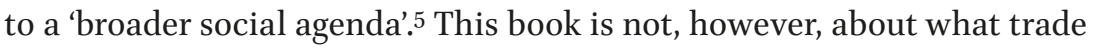
unions should or should not do, socially or politically, but about what they actually did, historically. Based on comparisons of long-term developments and focusing on transnational connections, its main contentions are that historically there have been many varieties of trade unionism, emerging independently or crucially transforming older ones, and that these varieties and transformations can be explained by specific and changing labour regimes. In short: new situations created new kinds of trade unionism.

The historical experiences of workers organizing in Europe and the United States in the nineteenth and twentieth centuries are just one among the many forms of workers' resistance resulting from the variety of labour relations in the global past, as becomes clear from the recent 'global turn'

1 Pigenet, Pasture, and Robert (eds), L'apogée des syndicalismes en Europe; Campbell, Fishman, and McIlroy (eds), The High Tide of British Trade Unionism.

2 For contemporary analyses: Crouch and Pizzorno (eds), The Resurgence of Class Conflict.

3 Cf. Fink (ed.), Workers across the Americas.

4 Bengtsson and Ryner, 'The (International) Political Economy of Falling Wage Shares'.

5 As in Gumbrell-McCormick and Hyman, Trade Unions in Western Europe, 1. 
in labour history. ${ }^{6}$ They cannot and will not be uniformly duplicated or copied from their present form in the global transformations of labour and workers' movements we are witnessing today. ${ }^{7}$ Nevertheless, in the twentieth century, trade unionism as a form of collective agency among workers became a global phenomenon, be it in very different national and political contexts. ${ }^{8}$ As of today growing numbers of workers are exposed to labour markets, so is it to be expected that new labour regimes based on wage labour will result in new varieties of trade unionism. The cases of workers organizing in the original heartlands of trade unionism in Europe and the United States, as analysed in this book, can provide a background for future prospects and transformations.

While the insight that supply and demand in the labour market have to be mediated by collective bargaining prevailed in most studies of trade unionism since Sidney and Beatrice Webb published their History of Trade Unionism in 1894 and Industrial Democracy in $1897,{ }^{9}$ hard-core neoliberals argue that regulation of labour markets in this way can only result in distortions of the 'natural' or 'equilibrium' wage, defined as the outcome of the unmediated interplay of supply and demand. Departing from a rigorous interpretation of neoclassical economic theory, they assert that 'the market' will adjust wages and employment levels to an equilibrium, which by definition has to be considered just or natural. Trade unions can enforce wage rises in excess of this competitive level only at the expense of consumers by raising prices and inflation, or of other workers by passing unemployment and low pay to less powerful sections of the wage-earning class, not at the expense of capital or profits. ${ }^{10}$

Contrary to neoliberal beliefs, however, a 'free' labour market, or indeed any market, cannot exist, and has never existed, without some form of regulation by countervailing powers. As soon as we abandon the assumption that the so-called competitive level of wages is the optimal outcome of supply and demand in the labour market, but instead accept that it can also result from an imbalance between these two, another perspective on trade

6 Cf. Hofmeester and Van der Linden (eds), Handbook Global History of Work.

7 Cf. Silver, Forces of Labor.

8 Phelan (ed.), Trade Unionism since 1945.

9 Webb and Webb, History of Trade Unionism, and idem, Industrial Democracy.

10 For the origins of anti-unionism in neoliberal thinking: Steiner, 'The Neoliberals Confront the Trade Unions'; Jackson, 'An Ideology of Class'; idem, 'Hayek, Hutt and the Trade Unions'; idem, 'Neoliberalism, Labour and Trade Unionism'. Mancur Olson later incorporated this idea into a general theory of the detrimental effects of 'distributional coalitions' (such as trade unions) and the need for 'market-augmenting governments': Olson, The Rise and Decline of Nations. 
unionism arises. Trade union pressure is needed to redress the imbalance of market power between employers and workers, to set wages above their 'competitive level' and to forge a redistribution of income between wages and company profits. The denial of an overall positive outcome of these efforts by neoliberals is reminiscent of the theory of the so-called wage fund, which dominated economic thinking about wages and trade unions until the late 186os. ${ }^{11}$ Indeed, one of the original contributors to neoliberal anti-unionist thinking, the British-South African economist W.H. Hutt, started from a kind of rehabilitation of nineteenth-century wage fund theory and a dismissal of later economists who had refuted it, including the Webbs. ${ }^{12}$

Until the late 1860s, in different formulas including Ferdinand Lassalle's 'iron law of wages', ${ }^{13}$ the wage fund theory was even held in the nascent labour movement, ${ }^{14}$ until it was discredited by the strike wave in those years. The famous address on 'Value, Price, and Profit' by Karl Marx, given before the General Council of the First International in 1865, was a refutation of the theory of the wage fund, as defended by one of its members, the Owenist carpenter John Weston. Weston argued that a general rise in the rate of wages would be of no use to the workers, and that therefore the trade unions had a harmful effect. He shared a view held by many trade unionists in this 'artisanal phase of the labour movement' (see Chapter 3) that only producer-cooperatives could increase workers' standard of living. Marx thought it was important to dispute this idea because, if it were accepted by the International, 'we should be turned into a joke both on account of the trade unions here and of the infection of strikes which now prevails on the Continent'. ${ }^{15}$ For him wage determination was 'a question of the respective powers of the combatants'. ${ }^{16}$ Trade unions were necessary to counteract the tendency of wages in an unregulated labour market to fall.

In this period of heightened union activity Marx put his faith in trade unions as the means of the formation and consolidation of class identity:

11 For an overview: Webb and Webb, Industrial Democracy, 603-617.

12 Hutt, The Theory of Collective Bargaining. Throughout this book, Hutt devotes a lot of space to discrediting W.T. Thornton, cited below (notes 22 and 23), who induced J.S. Mill to recant the wage fund theory. See also Jackson, 'Hayek, Hutt and the Trade Unions'. Interest in Hutt's argument that trade unions were inimical to working-class prosperity revived in the Thatcher years. His Theory of Collective Bargaining (originally published in 1930) was republished by the Thatcherite Institute of Economic Affairs in 1975.

13 For the popularity of Lassalle's 'iron law' in the early labour movement, see Chapters 2 and 3 in this volume.

14 Cf. Biagini, 'British Trade Unions and Popular Political Economy'.

15 Letter by Karl Marx to Friedrich Engels, 20 May 1865, cited in Marx, Value, Price and Profit, 2.

16 Ibid., 28. Cf. Donoghue, 'Marx on the Wages Fund Doctrine'. 
in their 'daily struggle against capital', unions could become 'a bastion against the power of capital' and 'schools of socialism. ${ }^{17} \mathrm{He}$ was well aware, however, of the exclusiveness of the British craft unions that had initiated the International. At the London conference of the International in 1871 he was very critical:

The Trade Unions [...] are an aristocratic minority - the poor workers cannot belong to them; the great mass of workers whom economic development is driving from the countryside into the towns every day - has long been outside the trade unions - and the most wretched mass has never belonged; the same goes for the workers born in the East End of London. ${ }^{18}$

In the early 1870 s for various reasons the British trade unions started to distance themselves from the General Council of the International. ${ }^{19}$ An example is the attitude of the London cigar-makers' union, which now tried to ally itself with other cigar-makers' unions on the continent in a separate international union (see Chapter 2).

During and after the strike wave of the 186os, the theory of the wage fund was abandoned by liberal economists as well, most famously by John Stuart Mill, who originally had been one of its staunchest defenders. His recantation in 1869, later described as 'one of the most curious episodes in the development of economic thought', ${ }^{20}$ is also one of the most debated..$^{21}$ Mill abandoned the traditional image of the labour market as a self-regulating mechanism after reading a defence of trade unionism by his friend W.T. Thornton, ${ }^{22}$ who had motivated this defence by referring to 'Labour's causes of discontent':

The upper myriads may cry Peace, but there will be no more peace for them, on the old terms, with the lower millions. Among these already widely exists, and is rapidly spreading, a profound dissatisfaction with labour's social position, and a firm determination to readjust it. ${ }^{23}$

19 Ibid., 529.

20 Ekelund, 'A Short-run Classical Model', 85.

21 Cf. Vint, Capital and Wages; Donoghue, 'Mill's Affirmation'.

22 Ibid., 96; idem, 'William Thomas Thornton and John Stuart Mill'; Mill, 'Thornton on Labour', 517-518, bluntly concluded: 'The doctrine hitherto taught by all or most economists (including myself), which denied it to be possible that trade combinations can raise wages [...] is deprived of its scientific foundation, and must be thrown aside.'

23 Thornton, On Labour, 36. 
The episode makes clear that theories of wage formation not only influence, but also reflect practices of trade unionism. ${ }^{24}$ In the preface to the 1871 edition of his Principles of Political Economy, Mill wrote 'there has been some instructive discussion on the theory of Demand and Supply, and on the influence of Strikes and Trade Unions on wages'. ${ }^{25} \mathrm{He}$ did

not hesitate to say that associations of labourers, of a nature similar to trade unions, far from being a hindrance to a free market for labour, are the necessary instrumentability of that free market; the indispensable means of enabling the sellers of labour to take due care of their own interests under a system of competition. ${ }^{26}$

Another prominent and influential opponent of the wage fund theory was the German liberal economist and social reformer Lujo Brentano, who in 1872 in a publication on British trade unionism supported the argument against the wage fund offered by Thornton. ${ }^{27}$ Like Mill, Brentano considered trade unions indispensable to arrive at regular industrial relations, a view which would later become pre-eminent in German social science. $^{28}$

This book is not about theory, however, but about the historical varieties of trade union practices exemplified by case studies over the course of three centuries. With Marx and Mill, and contrary to neoliberal or wage fund theories, it starts from the assumption that trade unionism is not an anomaly or a distortion, nor harmful, but a necessary and integral part of the functioning of labour markets in societies based on wage labour.

24 According to Donoghue, 'Mill's Affirmation', 95, 'Mill's support for trade unionism grew out of an evolving sympathy for the British Labour Movement in the 1860 s.' This is the reverse of W.H. Hutt's contention that wage bargaining in Britain developed only after John Stuart Mill and others had debunked the wage fund theory, as cited in Jaffe, Striking a Bargain, 20 and 103, note 6.

25 Donoghue, 'William Thomas Thornton and John Stuart Mill', 90.

26 Mill, Principles of Political Economy, 937.

27 Brentano, On the History and Development of Gilds, translation of Die Arbeitergilden der Gegenwart (2 vols, Leipzig 1871-1872), as referred to by Thompson, 'The Reception of Lujo Brentano's Thought'; see also Hennock, 'Lessons from England'.

28 Cf. Rudischhauser, Geregelte Verhältnisse, 257, 262-263; on the rejection of the wage fund doctrine by the German Historical School, see ibid., 217. In France, where classical political economy continued to be the dominant paradigm, this kind of theory remained en vogue, in spite of the criticisms in Britain itself: ibid., 233, 245. 


\section{Trade unions and labour market control}

From a sociological perspective, neoclassical and neoliberal economic theories can be criticized for ignoring institutionalizing tendencies in labour markets through both formal and informal social practices. ${ }^{29}$ Informal 'weak ties', social norms, group formation, and differences in skill, cultural preferences, gender, or social background cause a subdivision of the market into segments that are more or less separate. Social institutions and networks of social relations are needed to allow labour market transactions in different segments to take place. Trade unions belong to the institutionalizing forces that minimally act to regulate the labour market in their own segment, occupation, or industry, but historically they have been perceived in other roles as well, as instruments of class struggle, social control, or social dialogue, for instance. Trade union history has often been incorporated in (national) labour histories from such broader societal perspectives..$^{30}$ This collection of essays does not cover all these aspects, but concentrates on trade unions as workers' collective agencies to enforce regulation of wages and to control labour supply.

Since the defining work of Sidney and Beatrice Webb on British trade unionism, the view that unions seek to control and regulate labour markets has been widely held in various disciplines. ${ }^{31}$ This is not to deny that unions can pursue a much broader agenda, and in the twentieth century have increasingly done so, covering a wide area of social and political concerns, but their core business was and remains the protection of workers against the inherent risks and uncertainties of work relationships mediated by the market. In twentieth-century social science this view has been incorporated into a broader institutional approach of 'industrial relations', for instance in the American ('Wisconsin') Institutional School and the British so-called Oxford School, both of which were heavily influenced by the Webbs. ${ }^{32}$ In historical research the work of the Webbs, itself based on a thorough historical analysis of the British case, is still useful as a starting point. Eric Hobsbawm considered their main work, Industrial Democracy, 'the best

29 There is an extensive literature on this issue; for an overview: Streeck, 'The Sociology of Labor Markets'.

30 Cf. Hyman, Understanding European Trade Unionism.

31 Ibid., 6-17; Gahan, 'Trade Unions as Regulators'.

32 Kaufman, 'The Early Institutionalists'; Farnham, 'Beatrice and Sidney Webb'; Kaufman, 'History of the British Industrial Relations Field'. This is not to deny that the Webbs were also criticized by representatives of the Oxford School, most predominantly by Allan Flanders: see Jaffe, Striking a Bargain, 84-85, and Fox, 'Collective Bargaining, Flanders, and the Webbs'. 
book about unions ever written in our country',33 and industrial relations specialist Dave Lyddon concluded that 'for a theoretical framework, both Marxists and non-Marxists have had no choice but to look to the Webbs'.34

In the American institutionalists' view, a labour union resembles a cartel of firms in the product market in that both use their control of supply to exert market power over buyers and gain a higher price than a 'free' market would sustain..$^{35}$ In the German literature on industrial relations a trade union is considered a 'price-setting cartel of labour power' as well..$^{36}$ Even if the Webbs themselves did not invoke the term 'cartel' in this context, they certainly saw unions as price-fixing agencies which seek to modify market forces. ${ }^{37}$ In most cases labour markets tend to be unfavourable to workers, and when there is no way out ('exit') by leaving an employer and looking for a better job elsewhere, workers can only try to balance the process of wage determination by cartel-like union power ('voice'). $3^{8}$ In Industrial Democracy, Sydney and Beatrice Webb developed a typology of (historic) trade union action starting from this view. Unions try to control labour markets in basically three ways: by enforcing their own union rules on labour supply, by collectively negotiating 'common rules' with employers, and by demanding government regulation of labour standards. 39

'The device of restriction of numbers', as the Webbs call it, aimed at controlling labour supply by workers in skilled trades to maintain a privileged position and a relatively high standard of living, mainly by regulating the entry to an occupation by fixing the numbers of apprentices. By the time the Webbs were writing, this method, typically used by craft unions of skilled workers, had become obsolete because of the levelling of skills and working conditions in industrial societies. The cases of eighteenth-century cloth shearers and nineteenth-century glass-workers, described in Chapters 1 and 4 respectively, are clear examples of the effectiveness of this trade union device among skilled workers.

33 Hobsbawm, 'Trade Union Historiography', 33, cited by Lyddon, 'Industrial-Relations Theory', 136.

34 Ibid., 125; see also idem, 'History and Industrial Relations', 97-99.

35 Kaufman, 'The Early Institutionalists', 191.

36 Müller-Jentsch, Soziologie der Industriellen Beziehungen, 69.

37 Fox, 'Collective Bargaining, Flanders, and the Webbs', 159-16o.

$3^{8}$ Albert Hirschman's dichotomy of 'exit' and 'voice' has been used in a much-debated analysis of union behaviour in the United States by Freeman and Medoff, What Do Unions Do? Cf. Hirschman, Exit, Voice, and Loyalty.

39 Webb and Webb, Industrial Democracy, 704-740. 
By 'the device of the common rule', the Webbs argue, trade unions aim to negotiate a standard rate of pay and other working conditions with the employers, in order to enforce these regulations collectively. Such a collective agreement (a term the Webbs did not use) results in 'the exclusion from influence, on the contract, of all degradation of price', i.e., a lower rate of wages.$^{40}$ In this way, industries are forced to uphold a standard of work and to prevent the use of low pay by less efficient outsiders to compete. Such 'regulatory unionism' taking wages out of the competition has historically been, and still is, an important element of trade union practice. As is shown in Chapter 4 in the cases of glass and diamond workers in the nineteenth and early twentieth centuries, and in Chapter 7 for building cleaners in the late twentieth and early twenty-first centuries, it was used to force employers to regulate product markets as well, and these are just a few examples among many. The leader of the French union of textile workers, Victor Renard, for instance, argued in 1904 that collective agreements could force employers to form cartels to uphold prices and to stabilize markets. ${ }^{41}$ And in 1907 the German industrial relations pioneer Fanny Imle proposed to combine the regulation of wages in tariff agreements in the printing industry with the setting of market prices. ${ }^{42}$

Summarizing the mainly American literature on this issue, Peter Swenson calls this type of unionism 'negotiated cartelism': in sectors where competitors can enter easily, firms can turn to labour unions as an enforcement mechanism against cheaters and new entrants. ${ }^{43}$ In German this is called Schmutzkonkurrenz. ${ }^{44}$ Union power is used to stabilize competition by imposing a floor under wages paid by competing firms. Low-wage entrants to the trade are blockaded. In this way, minimum wage standards can prevent the destabilization of product markets. The union performs a function similar to that of a monopolistic supplier. As Swenson argues, in some industries - he mentions coal mining, clothing, and construction as US examples - employers had an interest in enlisting unions as the enforcers of a jointly managed cartel. ${ }^{45}$ This 'cross-class alliance' does not eliminate class conflict, however. Strikes remain the union's mechanism of enforcement on recalcitrant employers, and unions may use their power to impose

40 Ibid., 716. On debates on this issue in Germany and on the reception of the Webbs' ideas in France (by François Simiand): Rudischhauser, Geregelte Verhältnisse, 290-301.

41 Ibid., 376.

42 Cited by Stein, 'Die Schriften Fanny Imles', 117.

43 Swenson, Capitalists against Markets, 22-24.

44 Rudischhauser, Geregelte Verhältnisse, 154.

45 Swenson, Capitalists against Markets, 142-166. 
and maintain wage standards higher than the employers wish to go. But conflictual relations do not imply the absence of negiotiable alliances to regulate an industry, as the examples of the glass and diamond workers in Chapter 4, and the building cleaners in Chapter 7 , testify.

Apart from the 'Trade Union Methods of Collective Bargaining and Legal Enactment', the Webbs distinguish a third one of 'Mutual Insurance', important, but often neglected in nineteenth- and early twentieth-century trade union history. They mention out-of-work benefits as one of the crucial functions of trade union insurance. The object was to prevent unemployed union members under stress of starvation from accepting employment below standard wage rates agreed to or common in an industry, so this was another instrument to restrict and regulate labour supply..$^{46}$ The importance of out-of-work benefits for union policy is clearly established in Chapter 5 on the changing role of unions in labour intermediation in several European countries. Upholding this device even caused the abandonment of another closely related method of regulating labour supply: labour market intermediation by trade unions themselves.

The exercise of different forms of market control by trade unions, both by regulating labour supply and by collective bargaining, is a common theme in the case studies presented in this book. Each chapter is focused on specific trades or occupations to highlight the regulatory effects of trade union action in very different times and circumstances. They all depart from the concept of labour market control as the basic goal of union behaviour.

\section{Historical varieties of trade unionism and their transformations}

Through time the regulatory function of unions was linked to and to great extent determined by the way production was organized. ${ }^{47}$ How unions operated was reflective of the social and institutional contexts in which they emerged and developed. In the three centuries covered in this book labour relations changed fundamentally, and this is reflected in different forms of trade unionism. The chapters in this book are case studies of the

46 Webb and Webb, Industrial Democracy, 161-172; see on this issue also Dreyfus, et al.,'Les bases multiples du syndicalisme'.

47 In this context I deliberately avoid the concepts of 'mode of production' or 'regime of production', as the first (in the Marxian vocabulary) refers to societal formations as a whole (as in the 'feudal' or 'capitalist' mode of production), while the second is introduced in the debate on the 'varieties of capitalism' and refers to national differences: Soskice, 'Divergent Production Regimes', 101-134; Hall and Soskice, Varieties of Capitalism. 
transformations of trade unionism as a reaction to changes in production and labour regimes. As argued in Chapter 1, in the eighteenth century combinations of workers took the form of what I propose to call 'manufactural unionism', associated with the period of manufacture between independent producers and the factory age. Cloth shearers, whose frequent industrial action is the subject of this chapter, tried to establish combinations and representations to negotiate collectively with employers and to communicate with the authorities about a regulation of labour regimes. Manufactures in cloth shearing based on wage labour can be discerned already in Antwerp in the sixteenth century and in Amsterdam and Leiden in the seventeenth, as were industrial action and workers organizing in this period. The second half of the eighteenth century witnessed the apogee of this kind of 'manufactural unionism' by cloth shearers in Yorkshire and Wiltshire in England, in Sedan in northern France, and in the Verviers and Aachen region in today's Belgian-German borderlands. The case supports the argument by labour historians of the early modern period that there were 'unions before the unions'. ${ }^{8}$ Journeymen and other wage earners organized numerous strikes and built trade union-like structures to undertake collective negotiations well before the nineteenth century.

As there are few signs of a continuous evolution, I consider this kind of 'manufactural unionism', as exemplified by the cloth shearers, a separate episode in trade union history, not a kind of proto-unionism developing into unionism of a more permanent kind. In accordance with the Webbs' definition of trade unions, these 'manufactural unions' can be considered 'continuous' organizations of wage earners, but their existence contradicts the Webbs' assertion that there were no union-like structures of this kind before the nineteenth century. ${ }^{49}$ Nevertheless, in the nineteenth century a new kind of trade unionism emerged, initially not primarily in the factories developing out of manufactures, but among artisans in urban industries, such as tailors, shoemakers, cabinet-makers, and carpenters, whose formerly independent position was being undermined by middlemen, contractors, and other entrepreneurs. Labour historians distinguish an 'artisanal phase of the labour movement', when trade unions tried to restore artisan independence collectively by organizing producers' associations. ${ }^{\circ}$ Drawn into the market as wage labourers, they formed cooperative businesses to

48 As Lis and Soly argue in, 'An Irrestistible Phalanx"'; see also Rule, 'Review Essay: Proto-Unionism?'

49 Webb and Webb, History of Trade Unionism, 1.

50 Lenger, 'Beyond Exceptionalism', 1-23. 
control that market. Radicalized artisans became the standard bearers of a specific 'associational socialism' based on this solution. Starting from an international discussion and comparison of this issue in Chapter 3 , I show that such an artisanal phase can be clearly discerned in the early labour movement in Amsterdam. Trade unions as bargaining agents 'pure and simple' emerged only in the 1890 os as a reaction by a new generation of workers to changing labour regimes.

The artisanal origins of the early trade unions in the nineteenth century did not preclude them from operating as wage-bargaining agencies as well, in strikes and other forms of industrial action. A specific case is the early formation of trade unions among cigar-makers, as described in Chapter 2. This cannot be explained by a loss of artisanal status and independent position, as there was no artisan background or tradition in this trade. When cigar factories sprang up in European port cities in the first half of the nineteenth century, cigar-makers were recruited as wage labourers from the poorest strata of the population. They did not have an independent artisanal status to defend, but from an early date they realized that they had to combine to defend wages and working conditions.

Artisanal unionism of the kind described above, though originating in handicrafts, cannot be equated to the much broader English-language concept of 'craft unionism'. This refers to a model of trade unionism in which workers' organizations are based on a particular craft or trade in which they work, in contrast to 'industrial' or 'general' unions, in which all workers in the same branch or industry are organized into the same union, regardless of differences in skill. Again, the origins of craft unions were closely related to specific labour regimes. In nineteenth-century factories, the organization of the labour process often took the form of internal subcontracting by semi-independent craftsmen, who in their turn engaged auxiliary workers themselves. So, in the 1870 os in the American steel industry, a roller 'was not a supervisory worker - not a part of management, as his twentieth-century counterpart would be. He was an inside contractor, and often a prominent member of a union that regulated the terms under which work was subcontracted from the employers. ${ }^{51}$ In us engineering, inside contracting encouraged workers to become employers of other workers; a contractor took the contract at so much per unit, hired others on day rates, and pocketed the margin between his helpers' wages and the price the company had paid him..$^{2}$ In his extensive comparative study of industrial relations in German 
and American iron and steel manufacturing, Thomas Welskopp underlines the exploitive character of this form of subcontracting. ${ }^{53}$ Subcontractors were 'entrepreneurs rather than head workmen in their work team', and their relationship with the team was like a class relation 'en miniature. ${ }^{54}$

Subcontracting craft workers were the first to organize in craft unions, excluding their underlings. This kind of union emerged in the nineteenth century, but from the end of that century and in the first decades of the twentieth it was increasingly replaced by industrial unions. While these processes have been clearly established in the steel and engineering industries, especially in Britain and the United States, research on this issue in other industries is rare. In Chapter 4 I analyse this process comparatively in the Amsterdam diamond industry and in the Belgian and us window-glass industry. The importance of internal subcontracting in these industries was reflected in conflicts between different categories of workers. They often organized in different unions. However, overcoming these original divisions, a transition from 'craft' to 'industrial unionism' can be recognized in all three cases, be it in a very different way.

Mass industrial unions of workers in mining, textiles, construction, engineering, steel, automobile, shipbuilding, and other heavy industries, became dominant in the European and American trade union movement from the inter-war years, for instance in the American Congress of Industrial Organizations (CIO), but also in the French Communist Party, which (from 1936) had its main social base among mass industrial workers, like those in the mines and steel industries in the north and in the metal industries around Paris. 55 These industrial unions were at the heart of the post-war so-called Fordist class compromise, based on industrial mass production and mass consumption in industrialized capitalist countries. Under pressure of industrial mass unionism, governments and employer organizations tried to reconcile industrial interests with collective rights of predominantly male workers with permanent jobs in industry. ${ }^{6}$ During the phase of steady economic growth between the end of the Second World War and the mid1970s, forms of labour market regulation and protection of regular jobs came to dominate the industrial system in the North Atlantic industrialized countries.

54 Cited ibid., 126. See on this issue also Elbaum and Wilkinson, 'Industrial Relations and Uneven Development', 288-294.

55 Cf. Noiriel, Les ouvriers dans la société française.

56 Koch, 'Employment Standards in Transition'. 
From the mid-1970s business and governments turned against this kind of regulation and started to demand more flexibility in the labour market. To cut labour costs, employers sought to more easily adjust their workforce to supply and demand conditions by creating non-standard work arrangements, such as contracting out to subcontracting firms or self-employed workers, and temporary work on fixed time schedules. Under the impact of neoliberal labour market reforms, changes in employment relations have become structural: the so-called flexible fringe has grown substantially, and an increasing part of the labour force has to work and live under precarious conditions. From a broader historical perspective derived from Polanyi's Great Transformation, authors such as Guy Standing, formerly an economist for the International Labour Organization (ILO), and the American sociologist Arne Kalleberg analysed these developments as a process of 'recommodification' of labour after its 'decommodification' in the post-war welfare states. ${ }^{57}$ Pierre Bourdieu wrote about 'a mode of domination based on the institution of insecurity, domination through precariousness. [...] Institutionalized precariousness inside the firm of the future becomes a principle of work organization and a style of life. ${ }^{2}{ }^{8}$ Precarious work has, however, elicited new forms of resistance by different societal and union-like organizations. ${ }^{59}$

The pervasiveness of this phenomenon is illustrated by a sample of establishments collected by Kalleberg in the United States in the mid-199os: more than half of them had externalized or outsourced some of their activities. ${ }^{60}$ The cleaning industry is a paradigmatic example of this development. The symbolic value attached to its outsourcing by die-hard neoliberals can be illustrated with the forced dismissal of cleaners and school janitors by the Greek government as one of the 'reforms' demanded by the infamous 'troika' of the International Monetary Fund, the European Union, and the European Central Bank in 2012. In spite of the evidently marginal financial gains of this operation, their rehiring by the Syriza government in 2015 was one of first things the troika took issue with in its negotations with Syriza's finance minister Yanis Varoufakis. ${ }^{61}$ In Chapter 7 , I analyse new forms of

57 Standing, Work after Globalization; Kalleberg, GoodJobs, BadJobs, 24-26; cf. Polanyi, The Great Transformation. On the 'decommodification' of labour in post-war welfare states, see also Esping-Andersen, The Three Worlds of Welfare Capitalism, and Frade and Darmon, 'New Modes of Business Organization and Precarious Employment'.

$5^{8}$ Bourdieu, Firing Back, 29.

59 Lambert and Herod (eds), Neoliberal Capitalism and Precarious Work.

6 o Kalleberg, GoodJobs, BadJobs, 89.

61 Varoufakis, Adults in the Room, 151-154, 233-234, 522 note 6. 
trade union action to organize and empower precarious workers in this outsourced industry in the late twentieth and early twenty-first centuries.

\section{Comparative and transnational perspectives}

In contemporary sociological literature, the idea of 'varieties of unionism' departs not from changing labour regimes through history, but from varieties in trade union practices in the context of national 'varieties of capitalism'. ${ }^{62}$ These 'varieties' are broadly differentiated in 'liberal' (mainly in Anglo-Saxon countries) and 'coordinated' market economies (such as the Netherlands, Germany, Austria, Sweden). Class relations, as expressed in industrial relations, cannot be conceptualized only nationally, however. While in the twentieth century national institutions have clearly become important in shaping social and industrial relations, ${ }^{63}$ national labour movements have to cope with international class relations as well, as firms increasingly operate transnationally, linking production and work across borders. Under pressure of globalization, labour regimes converge. National states, both those with 'liberal' and those with 'coordinated' labour regimes, have implemented neoliberal reforms, resulting in a common neoliberal trajectory towards flexibilization of labour markets, precariatization of a growing number of workers, and a falling share of wages. ${ }^{64}$

This is not to say that nation-states have been outplayed in trade union action. They are still important in regulating labour markets and social security arrangements (as is also shown in Chapter 7), but they have rather been reconfigured as only one of the spatial dimensions trade unions have to operate in. As a result there has been a growing interest in labour internationalism and transnational trade unionism. ${ }^{65}$ The rise of global networks and transnational movements since the late twentieth century has (re)opened our eyes for transboundary developments and transnational connections in the history of labour movements as well. Rather than being a recent offspring of globalization, transnationalism appears to be an important aspect in the history of trade unionism, hidden from a view that was captured by 'methodological nationalism' (the assumption - mostly

62 Frege and Kelly (eds), Varieties of Unionism; Gumbrell-McCormick and Hyman, Trade Unions in Western Europe, 4; Hall and Soskice, Varieties of Capitalism.

63 Van der Linden, 'The National Integration of the European Working Classes'.

64 Baccaro and Howell, 'A Common Neoliberal Trajectory'.

65 Cf. Fairbrother, Hennebert, and Lévesque (eds), Transnational Trade Unionism. 
implicit - that the nation-state is the natural unit of social practices and of social research). ${ }^{66}$

Until recently, labour history could not escape 'methodological nationalism' and was mostly written within a national framework. Comparisons often started from discrete nation-states as units of comparison and from there were easily bound up with the idea of national exceptionalisms. Whatever the merits of these studies, several conceptual and theoretical contributions on the 'transnational turn' in labour history and a growing number of empirical studies showed how promising a transnational approach could be, also in making comparisons. ${ }^{67}$ The chapters in this book all start from a comparative and transnational perspective, based on two assumptions. The first is that developments in labour relations in the advanced capitalist countries (essentially western Europe and North America) followed a similar pattern and, although outcomes could be quite different, general tendencies in trade union reactions to these developments can best be studied from a comparative perspective 'beyond [national] exceptionalism'. ${ }^{68}$ This is achieved by making comparisons - not from a national perspective, but from the perspective of specific industries. A second, closely related assumption is that what at first seemed to be national developments in trade union history were in fact the result of intricate transnational connections and relations.

'Transnational' refers to the interaction between individuals, groups, and organizations across national borders, and to structures that extend beyond the nation-state. Transnational history has been focusing on border crossings and circulations, connecting people in cross-border social networks. These do not necessarily have to be worldwide, and in fact connect particular localities rather than nations. In cross-border studies the 'transnational' often dissolves into the 'translocal'. ${ }^{69}$ As the studies in this volume make clear, transnationalism in trade union history connected places rather than nations, at least before trade union internationalism was institutionalized in the cooperation of national unions in the twentieth century. Cloth shearers moved and transferred their traditions of industrial action from place to

66 Wimmer and Glick Schiller, 'Methodological Nationalism'; Chernilo, 'Methodological Nationalism'; Amelina, et al. (eds), Beyond Methodological Nationalism.

67 Van der Linden, Transnational Labour History; Hanagan, 'An Agenda for Transnational Labor History'; Kirk, MacRaild and Nolan, 'Introduction: Transnational Ideas' and 'Transnational Labour'; Fink (ed.), Workers across the Americas; McIlroy and Crouch, 'The Turn to Transnational Labor History'.

68 As is argued for in the case of the 'artisanal phase' of the labour movement by Lenger, 'Beyond Exceptionalism'.

69 French, 'Another World History Is Possible'. 
place: from Antwerp to Amsterdam, from Leiden to Sedan, and from there to Verviers; cigar-makers at the time of the First International connected Amsterdam and London, or Hamburg and New York, rather than Holland and England, or Germany and the United States; Belgian window-glass workers moved from Charleroi to Pittsburgh and localities in West Virginia, and Amsterdam diamond workers to Antwerp. Dutch and German miners met each other in Kerkrade and Kohlscheid, just across the border. The cleaners' campaigns in the late twentieth and early twenty-first centuries were based locally as well: in downtown Los Angeles and Houston, at London's Canary Wharf, and at Amsterdam Airport Schiphol.

\section{Transnationalism and trade union internationalism}

In one of the few theories of trade union internationalism, published in 1980, John Logue argued that this originally developed from concrete material self-interest grounded in the patterns of international mobility in the skilled trades prior to the First World War. Early trade unionists were receptive to the idea of internationalism because their personal experience made them feel part of an international working class. It was a rational choice to organize internationally to prevent wage cutting by migratory journeymen and to support wage demands in other countries. After the First World War internationalism declined, because unions gained strength nationally and were able to achieve on the national plane what they had previously sought to realize internationally. They supported various welfare state measures and protection of wages and working standards by restricting international labour mobility. ${ }^{70}$ This argument runs parallel to later arguments in economic history about a first globalization stretching from the nineteenth century until the First World War, followed by a period of nationalization (or 'deglobalization') in international economic relations, and a second phase of economic globalization (or 'reglobalization') in the 1990s and 2000s..$^{71}$

Logue's argument has been picked up and extended by Marcel van der Linden in reflections upon the national integration of the working classes in the late nineteenth and early twentieth centuries. ${ }^{72}$ So, well before

70 Logue, Toward a Theory, 10, 24-25, 46-49.

71 Broadberry and O'Rourke (eds), The Cambridge Economic History of Modern Europe, Vol. 2; Strikwerda, 'World War I in the History of Globalization'.

72 Van der Linden, 'The Rise and Fall of the First International'; idem, 'The National Integration of the European Working Classes'. 
'transnationalism' was coined as a concept to describe cross-border social relations, Logue and Van der Linden in fact argued that nineteenth-century trade union internationalism was based on the transnational mobility of workers and the existence of transnational labour markets. A salient example of international trade unionism based on such a transnational labour market is the International Federation of Ship, Dock, and River Workers (IFSDRW), founded in 1896 on the initiative of the British dockworkers' union, two years later to be renamed the International Transport Federation (ITF). It originated from a British attempt to coordinate strike action and organize solidarity with Rotterdam dockworkers. Its founders encouraged continental unions to join the British one to control the closely connected transnational labour markets of dockers and seamen, primarily in port cities around the North Sea. It organized members in local branches in both British and continental ports such as Hamburg, Rotterdam, and Antwerp, and supported strikes there, also by preventing strike breakers to be recruited by employers in those ports. ${ }^{73}$ During strikes in Antwerp in 1900-1901 and 1907, for instance, employers tried to import thousands of English workers to act as strike breakers. ${ }^{74}$ In the twentieth century the ITF developed into an international federation of national unions in the transport sector as a whole.

Logue's idea that trade union internationalism was a corollary of transnational labour migration is corroborated by the examples of the cigar-makers', window-glass workers', and miners' organizations described in Chapters 2 , 4, and 6. As I show in these cases, their internationalism was not (primarily) motivated by an internationalist (socialist) ideology, but was intended to regulate transnational (and in the first two cases even transatlantic) labour markets: in the early 1870s, English, Dutch, Belgian, and German cigar-makers broke away from the First International to establish their own international cigar-makers' union (Chapter 2); in the 1880 os Belgian, English, and American window-glass workers organized internationally in the Us-based Knights of Labor to control migration between the centres of window-glass making in these countries (Chapter 4); and, in spite of its anti-socialist and anti-internationalist ideology, the Dutch Christian Miners' Union became a branch of the German Christliche Gewerkschaft for pragmatic reasons, as before the First World War Dutch and German mining labour markets were fully integrated (Chapter 6). Its transnational

73 Simon, Die Internationale Transportarbeiter-Föderation, 85-92; Koch-Baumgarten, Gewerkschaftsinternationalismus, 48-53.

74 Vanfraechem, Een sfeer om haring te braden, 32 and 50. 
orientation supports Logue's argument that trade union internationalism was primarily based on practical considerations, not on ideology.

The post-First World War 'national turn', as described by Logue and Van der Linden, is exemplified by the development of the Dutch Christian Miners' Union as well. After the First World War it severed its connections with the German union and reoriented towards the Dutch state and mining district, even to the extent of campaigning against cross-border labour migration by German miners. National institutions continue to be important in trade union action even today. In Chapter 7 on the late twentieth- and early twenty-first-century 'Justice for Janitors' campaigns, the tension between transnational trade unionism and the national regulation of labour markets is a central theme. The case is illustrative of the limited value of so-called International Framework Agreements, as propagated by the International Labour Organization, ${ }^{75}$ which were concluded for cleaners/janitors by the international union of service workers, UNI Global Union.

After the First World War trade union internationalism primarily consisted of cooperation of national unions and federations, institutionalized in international federations of which the social democratic International Federation of Trade Unions (the so-called Amsterdam International, established in 1919) was the most important.$^{76}$ The communist Red International (or Profintern, 1921) and the International Federation of Christian Trade Unions (1920) were federations of national unions as well.77 This kind of internationalism presupposed workers organizing on a national basis and differed fundamentally from the earlier international unionism originating from cross-border mobility and social connections of the workers themselves. After the Second World War, the emergence of welfare states as part of the 'Fordist class compromise' based on the power of mass industrial unionism reinforced the national orientation of trade unions. Although there can be no doubt that there was intensive international exchange of ideas about welfare arrangements (as is attested in Chapter ${ }_{5}$, for example, in the case of labour market intermediation), this resulted in a strengthening of national labour market institutions, thereby effectivily hindering transnational mobility on which pre-welfare state international unionism had been based. This co-construction of state welfare and national trade unionism came under strain from the late 1960 s because of mass migration of both labour and

75 Cf. Fichter and McCallum, 'Implementing Global Framework Agreements'.

77 Cf. Tosstorff, The Red International of Labour Unions; Pasture, Histoire du syndicalisme chrétien international. 
capital, a development which lies outside the scope of my research. However interesting a comparative study of mass industrial unionism and its demise in the twentieth century would have been, these developments fall outside the cases I present in this book, focused on transnational connections from a social perspective.

\section{A social interpretation of trade unionism}

Many trade union histories tend to be written from an institutional perspective: they analyse membership figures, organizational structures, splits and/or mergers, leadership changes, participatory practices and bargaining results. Other histories concentrate on unions as social movements in strikes and other repertoires of industrial action. There is nothing wrong with that, but in the chapters of this volume I intend to go beyond these kind of institutional and events-based histories and look for social circumstances and conditions to explain changes in union structures and strategies. Transformations of trade unionism will be related to specific social developments. Adding to their comparative and transnational perspectives, the case studies in this volume are illustrative of a social interpretation of trade unionism. Key variables are the social base and composition of union membership, labour market segmentation, varieties of skill, workplace organization and the labour process, generational change, transnational migration, and cross-border social relations. As unions were a predominantly male domain and as it was only in the twentieth century that women started to organize, hesitantly, as industrial workers (which does not mean that they were absent in industrial or other actions), ${ }^{78}$ most of these studies concern male workers only. Women became important, however, and even leaders, in the transnational 'Justice for Janitors' campaigns in the late twentieth and early twenty-first centuries (as described in Chapter 7), a clear sign that female trade unionism - especially in the service sector - is on the rise and one of the new transformations we can expect in the future. ${ }^{79}$

78 In 2015 Silke Neunsinger (Stockholm) and Susan Zimmermann (Budapest) started a project on 'Women and Trade Unions in Europe, 19th to 21st centuries', but as of mid-2018 there have been no publications. See http://history.ceu.edu/women-and-trade-unions-europe-19th-21st-centuries (accessed 14 September 2017). For Britain see Boston, Women Workers and the Trade Unions.

79 On the situation in the United States: Milkman, 'Two Worlds of Unionism'. 


\section{On the origins of this volume: transnationalizing Dutch trade union history}

Just like in other countries, until recently Dutch labour history suffered from 'methodological nationalism', and, as it was almost exclusively written in Dutch, it was virtually unknown to an international readership (with some exceptions). All chapters in this book incorporate a Dutch element from a comparative or transnational perspective: Leiden cloth shearers in the seventeenth and eighteenth centuries figure next to Amsterdam cigar-makers, diamond workers, carpenters, and typographers in the nineteenth, Limburg miners in the early twentieth, and Dutch cleaners in the twenty-first century. In this way the book offers an opportunity to get acquainted with aspects of Dutch labour history for readers who are not familiar with the Dutch language. ${ }^{80}$

At the start of my research, my perspective on trade unionism was heavily influenced by the work of my thesis supervisor Theo van Tijn (1927-1992), a professor of social and economic history at Utrecht University between 1967 and 1992. Originally an urban historian of nineteenth-century Amsterdam, he turned to trade union history to contribute to ongoing debates on this topic in the Netherlands in the 1970s. He defined a trade union as 'a sales cartel of labour power, ${ }^{81}$ without any reference, however, to the research tradition of the Webbs and the institutionalist school in industrial relations. ${ }^{82}$ Chapter 3 in this volume on the early labour movement in Amsterdam was originally written as a paper on the occasion of his retirement (published in 1993) ${ }^{83}$ For the translation and publication in this volume it has been thoroughly revised and updated.

Van Tijn's research in trade union history began with a study of the Amsterdam diamond workers' union, the Algemeene Nederlandsche Diamantbewerkers Bond (ANDB, established in 1894), ${ }^{84}$ one of the most successful and influential unions in Dutch trade union history. When in 2010 I learned about industrial relations in the Belgian window-glass industry through the doctoral dissertation of Widukind De Ridder at Brussels Free University, ${ }^{85}$ I was struck by several similarities with union practices in the

80 Chapters originally published in Dutch are translated by myself, as are quotations in Dutch, French, and German.

81 Van Tijn, 'A Contribution to the Scientific Study'.

82 See on this issue Schrover, Nijhof, and Kruisinga, 'Marx, markt, macht'.

83 Knotter, 'Van "defensieve standsreflex".

84 Van Tijn, 'De Algemeene Nederlandsche Diamantbewerkersbond'.

85 De Ridder, 'Loonsystemen'. 
Amsterdam diamond industry, as described by Van Tijn, and I decided to study these cases comparatively. Because of recent work of Ken Fones-Wolf on American window-glass workers, it became possible to include these in the comparison as well, and also to add a transnational element, as there was a lively migratory exchange of Belgian glass-workers across the Atlantic. The resulting article in Dutch was later thoroughly reworked for English-language publication in Labor History and is reprinted here as Chapter $4 .{ }^{86}$

In the meantime, Sigrid Wadauer at Vienna University had found out that I had a special interest in labour market history, and in 2009 she asked me to contribute to a workshop on labour intermediation organized for her research project 'The Production of Work'. ${ }^{87}$ Through this invitation, my interest in this topic, dormant since I had finished my doctoral dissertation on the Amsterdam labour market in the nineteenth century in $1991,{ }^{88}$ revived, and I was able to present a paper on the changing role of trade unions in labour market intermediation in western Europe in the nineteenth and early twentieth centuries. In 2015 a volume, mainly based on the papers of this workshop, was published. Chapter 4 is a reprint of my contribution to this volume. ${ }^{89}$

In the research for my dissertation I had encountered both the migratory behaviour and the early trade unionism of Amsterdam cigar-makers, and when Marion Fontaine, secretary of the French Société d'études jaurésiennes, asked me to contribute to a conference organized by this society on the history of both the First and the Second International, $9^{\circ}$ I decided to expand on this research, and to relate the transnational migratory connections of the cigar-makers to their internationalism. The paper, which was also discussed at an another Parisian conference commemorating the First International, organized by Fabrice Bensimon, ${ }^{91}$ was published

86 Knotter, 'De Amerikaanse en Belgische vensterglasindustrie'; idem, 'Trade Unions and Workplace Organization'.

87 See http://pow.univie.ac.at/, 'The Production of Work: Welfare, Labour-Market and the Disputed Boundaries of Labour (1880-1938)‘ (2008-2013).

88 Knotter, Economische transformatie.

89 Wadauer, Buchner, and Mejstrik (eds), The History of Labour Intermediation, 117-150. A shortened version appeared in French: 'Du contrôle des services de placements'.

90 '1914, l'Internationale et les internationalismes face à la guerre', Paris, 24-25 March 2014, http://www.jaures.info/news/index.php?val=191_colloque+international+\%22+1914+internati onale+internationalismes+face+guerre $\% 22$.

91 'Il y a 150 ans, l'Association Internationale des Travailleurs', Paris 19-20 June 2014: https:// ait1864-2014.sciencesconf.org/. See also Bensimon, Deluermoz, and Moisand (eds), 'Arise Ye Wretched of the Earth'. 
in the International Review of Social History in 2014 and is reprinted in this volume as Chapter $2 .^{92}$

Then Marcel van der Linden suggested that I assemble these studies for submission as a volume, and that triggered me to look for more opportunities to study transnational aspects of trade union history. Chapters 1 and 6 are spin-offs of my research in the borderlands around Maastricht, where since 1998 I have held a professorship in comparative regional history and directed a research programme in 'historical border studies'. One of the projects was on cross-border mining labour markets in the Dutch-Belgian-German borderlands, ${ }^{93}$ and when it appeared that the early development of miners' trade unionism was closely related to the development of these labour markets, I decided to study this relationship more closely (Chapter 6). Doing research on cross-border connections in the textile industry in this area in the eighteenth century, I found out about the international connections of the militant cloth shearers in the borderlands around Aachen and Verviers, just to the east and south of Maastricht. ${ }^{94}$ The search for the international background of their militancy brought me to textile industries all over Northwestern Europe in the seventeenth and eighteenth centuries (Chapter 1).

International students in my Maastricht Faculty of Arts and Social Sciences appeared to be interested in debates on precariousness, and what to do about it, and I decided to organize a seminar on the cleaners' strikes in the Netherlands between 2010 and 2014, which were clearly copied from the campaign 'Justice for Janitors' from the late 1980 s in the United States. The resulting research paper was published in the International Review of Social History in 2017 and is reprinted here as Chapter $7 \cdot{ }^{95}$

92 International Review of Social History 59(3) (2014), 409-422. An abridged and translated version appeared in the proceedings of the Jaurès-conference: Knotter, 'Les ouvriers du cigare à l'échelle transnationale'.

93 Knotter, 'Labour Migrants'; idem, 'Changing Border Regimes'.

94 Idem, 'Land van heel veel grenzen'. A German version appeared as idem, 'Land der vielen Grenzen'. A portion was published in French 'Pays sans frontière?'

95 International Review of Social History 62(1) (2017), 1-35. 



\title{
$1 \quad$ An international of insolence
}

\author{
The great anger of the cloth shearers in north-western \\ Europe in the eighteenth century
}

\begin{abstract}
Discussing journeymen's associations 'before the unions', Rina Lis and Hugo Soly argued against a purely symbolic interpretation of collective actions by pre-industrial artisans in defence of custom and honour, supposedly in contrast to industrial action by nineteenth-century trade unions. Journeymen often formed associations that operated like trade unions and were able to develop repertoires and negotiating techniques aimed at controlling labour supply and regulating the labour market. One of the more salient examples is the cloth shearers, who were in the forefront of industrial action in the seventeenth and eighteenth centuries everywhere in western Europe. In this chapter, I first give an overview of their transnational connections and actions in several European countries. Then I focus on the proto-industrial textile region between Aachen and Liège and on the way the territorial fragmentation of these borderlands impacted upon the agitation of the shearers over the control of their labour market in the eighteenth century. My conclusion is that the cloth shearers exhibited a specific variety of 'manufactural unionism', associated with the period of manufacture between independent artisans and the factory age.
\end{abstract}

Keywords: journeymen's associations, manufactural unionism, cloth shearers, textile industry, borderlands, Germany, Aachen, Verviers

Knotter, Ad, Transformations of Trade Unionism: Comparative and Transnational Perspectives on Workers Organizing in Europe and the United States, Eighteenth to Twenty-First Centuries. Amsterdam, Amsterdam University Press, 2018 DOI: 10.5117/9789463724715_CHO1 
Si une internationale ouvrière se forma, un jour avant 1864 , ce fut bien une internationale de l'insolence, celles des tondeurs des draps. ${ }^{1}$

In the eighteenth century various industrial centres in the textile region between Liège, Aachen, and Maastricht were competing, across territorial borders, over the labour force in the countryside in a complex network of relations between employers and workers. ${ }^{2}$ The main industrial centres were: Aachen (Aix-la-Chapelle), with adjacent independent Burtscheid (Borcette); Verviers, with smaller centres Hodimont and Dison nearby; Eupen; and Monschau (Montjoie). ${ }^{3}$ They competed over the labour supply, primarily in the territory of the duchy of Limburg, situated between Verviers, Aachen, and Monschau. The duchy of Limburg was part of the Austrian Netherlands (governed from Brussels). Only the textile centres of Hodimont, Dison, and Eupen belonged to Limburg. Verviers was located in the marquisette of Franchimont, which was part of the prince-bishopric of Liège. Monschau was in the duchy of Jülich; Aachen was a free imperial city; Burtscheid was governed by the local abbey. ${ }^{4}$ Around and in between these larger centres were many small rural villages occupied by peasant weavers and spinners, ${ }^{5}$ and also by cloth shearers: between the textile centres genuine shearers' villages had emerged from which workers regularly commuted to the towns where their workshops were located. ${ }^{6}$

What was the effect of these territorial divisions on the labour relations in the textile industry in this area? In an influential interpretation, the Liège historian and liberal politician Jean Lejeune (1914-1979) called this a pays sans frontière, a land without borders, and he referred to the eighteenth-century textile industries as an example: 'in the end mutual interests [in the textile industry] were intertwined to such an extent that they couldn't be separated'. In support of his argument he cites a statement of the Limburg Estates in 1764 (21 March), that, according to him, could testify to the integration of labour markets in this textile region as a whole:

that it would be very difficult to make regulations [for the workers in Limburg] without the cooperation of those of Liège, Jülich, Aachen, and

1 Gayot, Draps de Sedan, 217.

2 Dechesne, Industrie drapière, 37.

3 The distances are: Aachen-Verviers: c. 40 km; Verviers-Eupen: c. 16 km; Eupen-Monschau:

c. $25 \mathrm{~km}$; Aachen-Eupen: c. $20 \mathrm{~km}$.

4 Minke, 'Die politische Verhältnisse zwischen Maas und Rhein'.

5 Engels, Die Zollgrenze in der Eifel, 30.

6 Syré, 'Ein Wirtschaftsraum bleibt erhalten!' 
Figure 1.1 Map of the territorial borders in the area between Aachen and Liège in the eighteenth century

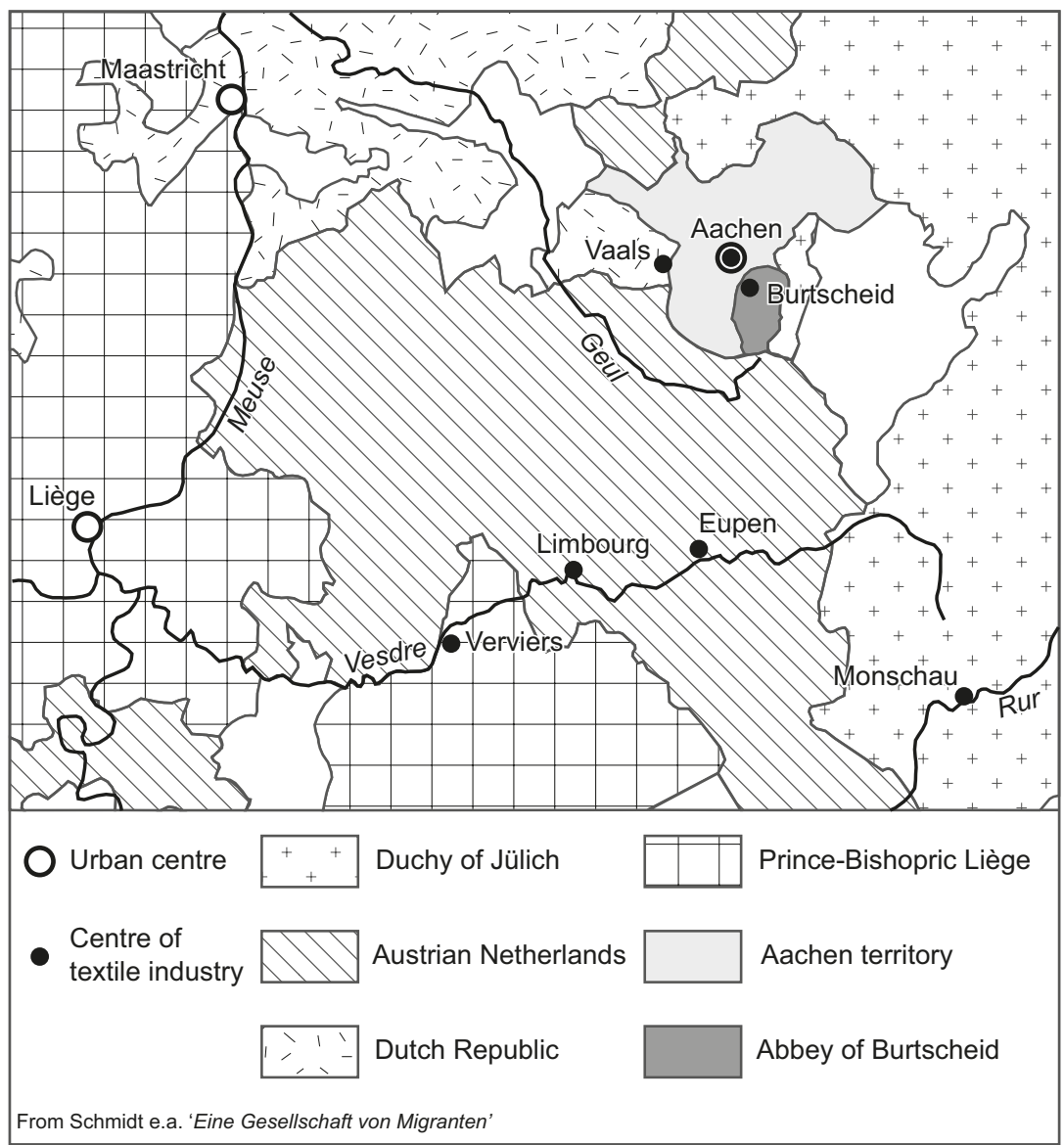

Burtscheid to introduce a uniform ruling everywhere that would not privilege one territory over another. ${ }^{7}$

On closer look, however, this statement in fact falsifies Lejeune's proposition of a land without borders, as the Limburg authorities argued that territorial divisions were so important that it would not be possible to regulate labour relations for all territories together. A request for a general ruling was made by representatives of striking cloth shearers in Limburg (Eupen and Hodimont), who wanted to regulate their labour market and 
to end the arbitrariness of the employers in setting wages and conditions of employment. The shearers wanted to control labour supply by limiting the employment of 'foreigners' and apprentices; to fix wages and the exchange rate of circulating money these were paid in; an obligatory relief fund; and the appointment of factory inspectors on these issues by the government. ${ }^{8}$

Asked for advice by the Estates on this request, the Limburg employers spoke out against such a regulation: they claimed a right as employers to act on the labour market as they pleased, to have free choice of workers and the ability to adapt wage levels to the market, arguing that regulation of the labour market as demanded by the shearers would only harm their competitiveness vis à vis cloth merchants in surrounding territories. The Estates agreed: because it would not be possible to coordinate these regulations across borders, regulation of labour in Limburg alone would privilege competitors in other textile centres in the area and harm employers in the Limburg region. Their statement was a final reaction to a number of complaints and requests by shearers from Eupen addressed to the authorities to limit the number of apprentices according to custom, and also for a wage rise, partly under threat of a strike. ${ }^{9}$

In this period shearers were agitating for labour market regulation in strike actions in several locations in the Aachen-Verviers region: in Verviers and Hodimont (1759), in Aachen (1760), in Monschau (1762 and 1763), and in Burtscheid (1765). The agitation can be considered a culmination of what the French historian Gérard Gayot (1941-2009) in his history of the woollen industry in Sedan, not too far away in northern France, has called la grande colère des tondeurs ('the great anger of the cloth shearers') in the eighteenth century. ${ }^{10}$ The strikes around 1760 had been preceded by ones in Sedan in 1712, 1748, and 1750, in Eupen in 1721 and 1722, and in Verviers and Monschau in 1742-1743, and were later followed by strikes in Verviers and Ensival in 1781 and 1789 , and in Eupen and again Monschau in 1797-1798 (see Table 1.3). ${ }^{11}$ In this chapter I will focus on the agitation of the shearers in the proto-industrial textile region between Aachen and Liège in the eighteenth century and on the way the territorial fragmentation of these borderlands impacted upon their struggles over control of the labour market.

8 Dechesne, Industrie drapière, 214.

9 Ibid., 217; Henkel, 'Taglohn, Tradition und Revolution', 55-57.

10 Gayot, Draps de Sedan, 19o. The distance between Sedan and Verviers is c. $160 \mathrm{~km}$.

11 Ibid., 189-190; idem, 'La longue insolence'; Barkhausen, Die Tuchindustrie, 81, 96; Fairon, 'La question ouvrière', 45; idem, 'Les industries du Pays de Verviers', 38 ; Hermanns, 'Die Tuchscherer', 154-161; Henkel, 'Taglohn, Tradition und Revolution', 49-53; Minke, 'Arbeiterunruhen'. 
Figure 1.2 Bronze statuette representing a cloth shearer adorning the top of the Weberbrunnen fountain in Monschau

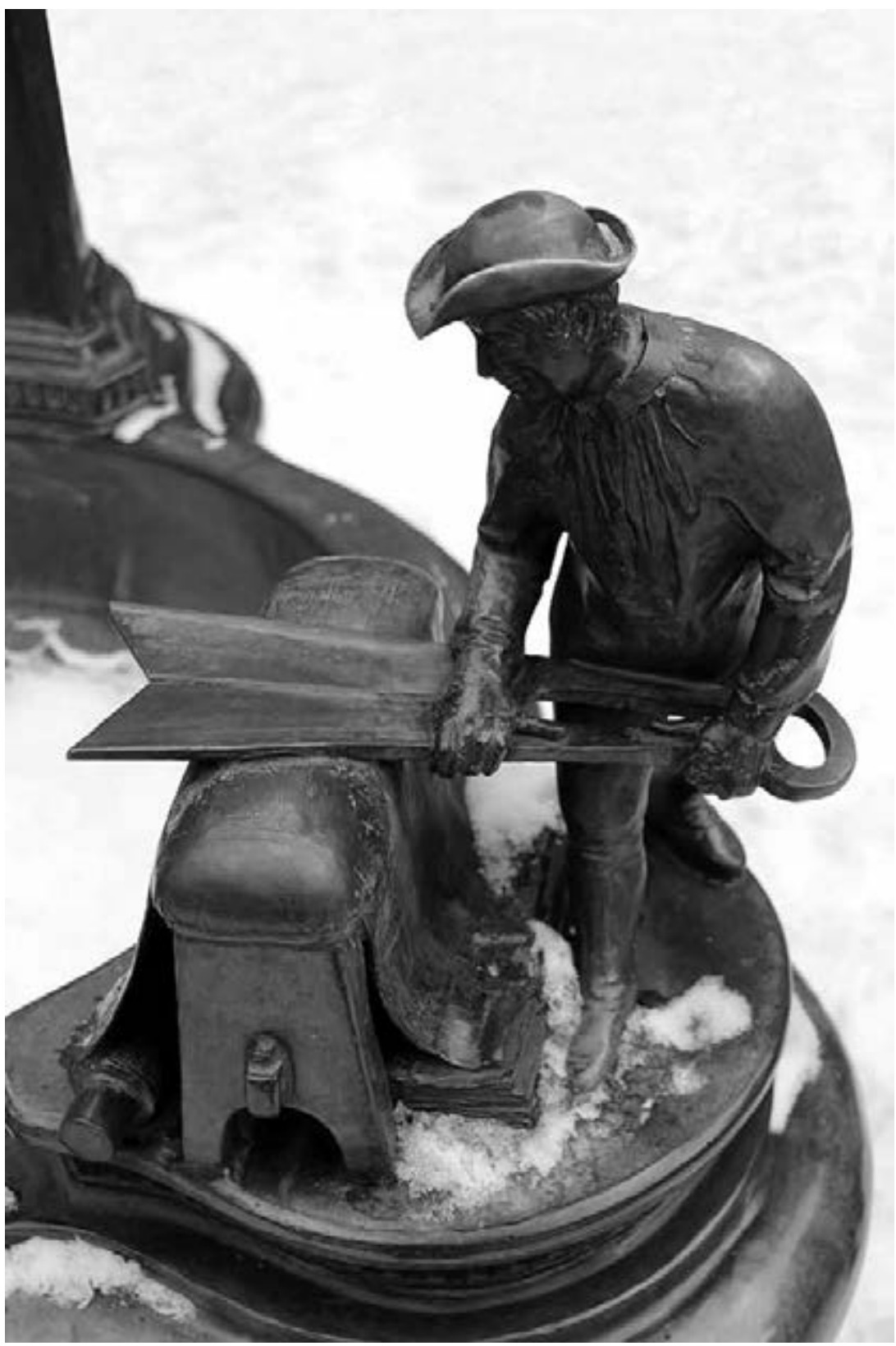

Sculptor Bonifatius Stirnberg. Available at https://tinyurl.com/y953gm5f 
The militancy of the shearers was facilitated by their migratory behaviour between the centres of textile production in the whole of north-western Europe. Gayot wrote about 'the circular migration of skilled workers in the triangle formed by [the Dutch textile town of] Leiden, Aachen, and Sedan', that 'created a favourable climate for the exchange and harmonization of professional customs. [The shearers shared] a common language, methods of work, and a common social behaviour in industrial action. ${ }^{12}$ And elsewhere: 'the art of industrial action was the best shared vice and virtue in the world of labour in the European draperies. If a workers' international was formed, sometime before 1864 [i.e. the founding of the First International], it was an international of insolence, that of the cloth shearers. ${ }^{\prime 3}$

The Sedan draperies were set up by the French state in 1646 to create an industry façon d'Hollande. To establish such an industry, Sedan recruited shearers from Leiden, and these not only brought the techniques and customs of the trade, but also the repertoires and rituals of collective action. A strike in Sedan was called cloque, possibly from the Dutch word klok ('clock' or 'bell' in English). ${ }^{14}$ Germany and England were mentioned as places of origin as well. From the late seventeenth century shearers regularly migrated between Sedan and the Liège and Aachen regions, especially between Sedan and Verviers. ${ }^{15}$ By working together in different locations, migrants easily became familiar with action repertoires and rituals. Shearers were also 'imported' into Burtscheid, Eupen, and Monschau, when in the late seventeenth and early eighteenth centuries a fine cloth industry was set up there. From 1680 clothiers in Eupen recruited shearers from France, Holland, Saxony, and other parts of Germany. In 1723 their number had grown to around 400, mainly from the Aachen and Liège regions, but also from France (Sedan) and Holland (Leiden)..$^{16}$ It is hard to understand the grand colère des tondeurs in the Aachen-Verviers region in the eighteenth century without taking these transnational connections into account.

12 Gayot, Draps de Sedan, 197.

13 Ibid., 217. See also idem, 'La longue insolence', 130-131.

14 Gayot, Draps de Sedan, 218; in Eupen the term 'clocke' was used for the hourly pause the shearers were allowed, signalled by a clock: Henkel, 'Taglohn, Tradition und Revolution', 51.

15 Gayot, Draps de Sedan, 216-217. Between 1738 and 1748, 14 per cent of males marrying in Sedan had been born in Verviers and the Limburg region: ibid., 195.

16 Hermanns, 'Die Tuchscherer', 150-153; Henkel, 'Taglohn, Tradition und Revolution', 49; Schmidt, 'Burtscheid um 180o', 72. 


\section{Proto-unionism?}

Everywhere in north-western Europe cloth shearers were among the most militant of textile and other early industrial workers. In England they were known as shearmen or croppers, and were sometimes referred to as cloth workers. In Yorkshire their tradition of militancy culminated in the notorious Luddism, or machine breaking, at the beginning of the nineteenth century (1811-1812). ${ }^{17}$ The introduction of shearing machines caused the same kind of rebellion in Eupen in 1821 and in Verviers in 1819 and $1830,{ }^{18}$ and also played a role in subsequent social unrest in Aachen in $1830 .{ }^{19}$

Shearers were responsible for finishing a piece of woollen cloth after it had been fulled by cutting off the rough surface to leave it smooth and even. Large hand shears were used over a bench, with one blade laid down and the other being pushed by the shearer. Shearing was done in workshops, sometimes owned by small masters who subcontracted the work, but increasingly concentrated and owned by the clothiers themselves. The work required not only great skill, but also considerable muscle power. Because of their skill and its importance for the quality of the finished cloth, they were considered the 'most needed workers' in the woollen industry. ${ }^{20}$

The shearing industry is a typical example of what Marx called a 'manufacture': although concentrated, the production process was based on skill as a 'property' of the workers themselves, and 'capital had continually to wrestle with the insubordination of the workers'. ${ }^{21}$ Through combinations skilled workers were able to face the employer with effective tactics of industrial action and to exert a degree of control over the labour process and the labour market. To control labour supply, restriction of entry to the trade by regulation of apprenticeship was crucial. As John Rule remarked, in the 'manufacturing period' unions of skilled workers struggled to preserve and control apprenticeship as a functional equivalent of the modern 'closed shop', and collective action increasingly became a means of restricting entry. ${ }^{22}$

17 Randall, Before the Luddites; see also Thompson, The Making of the English Working Class, 569-579.

18 Henkel and Taubert, Maschinenstürmer, 31-140; Jarrige, Au temps des 'tueuses de bras', 67-70.

19 Althammer, Herrschaft, 177-202.

20 Cf. Gayot, 'Les “ouvriers les plus nécessaires”'; cf. Randall, Before the Luddites, 112: 'The value of the finished cloth depended much on the quality of the cloth dresser's work. [...] It was this vital role in the woollen industry which gave the cloth dressers their privileged status and strong bargaining position.'

21 Cited by Rule, 'The Property of Skill', 99.

Ibid., 101. 
In the West Country of England, before the advent of the deskilling shearing frames, the shearmen were noted as a closely knit craft group keeping a tight restriction on entry. Journeymen refused to work with those whom they did not regard as 'regular'. ${ }^{23}$ 'From time immemorial [they have] rendered their craft a species of monopoly by limiting the number of apprentices', noted an observer in $1799 .{ }^{24}$ Shearers were organized on a local basis from at least the 1740 s. In 1769 a county-wide federation in Wiltshire and Somerset was involved in a dispute over apprentices and wages, and other industrial conflicts in the West Country are recorded in 1787,1788 , and 1791. From 1796 they united under the name of 'Brief Institution', centred in Leeds (Yorkshire), to enforce apprenticeship regulations and oppose the introduction of finishing machines. The 'Brief Institution' effectively linked the cloth shearers in Yorkshire and the West of England in one federative union. Representatives of various local workshops formed local committees, who in their turn nominated delegates to form a Central Committee. In 1802 it organized strikes and disturbances known as the Wiltshire Outrages. ${ }^{25}$

The mobility of the shearers enabled the customs and traditions of collective action to spread widely around Europe. According to Gayot, this concerned a 'professional heritage transmitted by travelling journeymen of the old west European draperies in the course of the seventeenth century'. He asserts that 'the English cloth workers kept following customs that they had established together with their Dutch comrades.. ${ }^{26}$ One of these customs was the declaration of workshops and workers to be 'foul' when customary regulations of labour were ignored. In Holland the Dutch word vuil was used, ${ }^{27}$ in French-speaking Sedan and Verviers this was called sale, or (in Verviers) pourrie, in German-speaking Eupen and Monschau faul, ${ }^{28}$ all with the same meaning of 'foul' or 'dirty'. ${ }^{29}$ The declaration of a workshop or a worker to be 'foul' was accompanied by ritual acts that the shearers experienced as compulsory. Both in seventeenth-century Holland and in eighteenth-century Sedan and the Aachen-Verviers region, a worker could

Ibid., 100.

24 Cited by Randall, Before the Luddites, 115 .

25 Ibid., 116-118 and 131-147; idem, 'The Shearmen'.

26 Gayot, Draps de Sedan, 216-217.

27 Dekker, 'Arbeidsconflicten in de Leidse textielindustrie', 73-74.

28 Gayot, Draps de Sedan, 214-218; Henkel, 'Taglohn, Tradition und Revolution', 50; Hermanns, 'Die Tuchscherer', 153 .

29 For workers being declared 'foul' in England: Rule, 'The Property of Skill', 112. According to anthropologist Mary Douglas, who analysed 'pollution rules' in her classical study Purity and Danger, what is regarded as 'dirt' in a given society is any matter considered out of place. 
'clean' himself from being declared 'foul' by buying his mates an amount of beer for a fixed price (called fricasse in Sedan). For the shearers, these customs and rituals had proven their effectiveness in industrial action, and they imposed them everywhere they went, but, according to Gayot, in doing so they also developed less secretive, less folkloristic strategies directed at the authorities to ask for arbitration and to enforce regulations. The attempt in 1764, mentioned above, to involve the Limburg authorities in their struggle for labour market control is a clear example.

For Gayot this was a sign that traditional repertoires of public agitation, such as negotiation by riot, were being replaced by trade union-like actions, in anticipation of union practices in the nineteenth century..$^{30}$ That shearers' strikes responded to rising labour demand, not to food crises, is a proof of this 'modernity'. ${ }^{11}$ As will be shown below, however, the shearers' strikes in the eighteenth century continued a tradition dating back to at least the seventeenth century, based on the concentration of skilled wage labour in 'manufactures' in Dutch cities such as Leiden and Amsterdam, and earlier still in Antwerp. Already in 1350, the mayor and aldermen of the City of London described this kind of behaviour by shearmen in an ordinance:

whereas heretofore if there was any dispute between a master in the said trade and his man, such man has been wont to go to all the men within the City of the same trade; and then, by covin and conspiracy between them made, they would order that no one among them should work, or serve his own master, until the said master and his servant, or man, had come to an agreement; by reason whereof the masters in the said trade have been in great trouble, and the people left unserved..$^{2}$

Historians of pre-modern labour John Rule and Rina Lis and Hugo Soly argued against a purely symbolic interpretation of collective actions by pre-industrial artisans in defence of custom and honour, in contrast to industrial action by nineteenth-century trade unions. Journeymen often formed associations operating like trade unions and were able to develop repertoires like strikes and negotiating techniques aimed at controlling labour supply and regulating labour markets. They found effective workers'

30 Gayot, Draps de Sedan, 218-220. The concept of 'negotiation by riot' was first used by Eric Hobsbawm and later developed by Rudé, The Crowd in History.

31 Gayot, Draps de Sedan, 220; idem, 'La longue insolence', 129-130.

32 Riley (ed.), 'Memorials: 1350'; British History Online, http://www.british-history.ac.uk/ no-series/memorials-london-life/pp247-265 (accessed 31 October 2016). 
coalitions at least half a millennium prior to the Industrial Revolution. ${ }^{33}$ Artisan journeymen were not only engaged in conflicts over customary practices and moral rights, but also made use of market conditions to settle wages. Nor can their insolence and ritual behaviour be separated from their attempts to get a grip on their working conditions. ${ }^{34}$

Debates on the continuity or discontinuity between 'pre-modern' journeymen's and 'modern' industrial trade union actions have a long history, in both British and German labour history. ${ }^{35}$ The discontinuity thesis owes a lot to the work of Sydney and Beatrice Webb, who defined trade unions as permanent and continuous organizations, and could not find many of these before the advent of the industrial era. Later and more recent research has taken a broader and more inclusive view of industrial action, but there is no agreement as to what extent there was continuity (apparently Lis and Soly's opinion), a fundamental break between an artisan pre-industrial 'moral economy' and the labour market rationality of industrial unions, or a development from crowd action and sporadic strike behaviour to more organized forms in a kind of 'proto-unionism' (as perhaps Gayot's position could be described). In my conclusion I will try to interpret my research on the struggles of the cloth shearers also from the perspective of this debate.

\section{Before the grande colère des tondeurs: cloth shearers' strikes in the Netherlands}

Preceding the grande colère des tondeurs in Sedan and in the Verviers-Aachen region, there had been a long tradition of industrial action by cloth shearers in the cities of Holland in the seventeenth century, brought to light by the Dutch historian Rudolf Dekker (see Table 1.1). ${ }^{36}$ In seventeenth-century Holland the two main centres of cloth finishing were Leiden and Amsterdam. While finishing in Leiden was part of the city being one of Europe's most important centres of cloth production, in Amsterdam cloth shearing was attached to the trade in woollen cloth by Amsterdam merchants, called a trafiek in Dutch. ${ }^{37}$ The industry had been established there, or had at least

Lis and Soly, '“An Irresistable Phalanx"'; Rule, 'Review Essay: Proto-Unionism?'

4 Cf. Truant, 'Independent and Insolent'.

35 Cf. Reith, 'Arbeitsmarkt und Gesellenstreik', 177-179; Rule, 'The Formative Years'.

36 Dekker, 'Arbeidsconflicten in de Leidse textielindustrie'; idem, “'Getrouwe broederschap”; idem, 'Labour Conflicts'.

37 According to Ormrod, The Rise of Commercial Empires, 16, there is no exact equivalent for this word in English: trafieken are processing industries based on the 'traffic' and storing of 
experienced an enormous boost, by Antwerp merchants who had moved to Amsterdam after the closure of the Scheldt river by the Dutch Republic in 1585 , and who had taken the industry and its workers with them. ${ }^{38}$

In the sixteenth century, cloth shearing had been an important industry in Antwerp, based on the import of English cloth. ${ }^{39}$ There had been a regular immigration of shearers to Antwerp from Germany, from the textile towns of Aachen and Cologne among others, where cloth manufacturing was declining in this period, precisely as a consequence of the expansion of the finishing industry in Antwerp based on the import of raw English cloth. ${ }^{40}$ English merchants were the biggest employers in the Antwerp cloth-shearing business. In 1565 they decided to take their raw cloth elsewhere to be sheared, and many Antwerp-based cloth shearers followed them to German cities such as Hamburg, ${ }^{41}$ where English merchants had taken skilled Antwerp shearers already in $1530 .{ }^{42}$ After 1585 Antwerp cloth merchants migrated to Hamburg as well, ${ }^{43}$ so cloth shearing as a port industry moved with the migration of Antwerp cloth merchants to both Amsterdam and Hamburg. In the seventeenth century migration circuits of cloth shearers can be found connecting Amsterdam with Hamburg, and also with the Aachen region. ${ }^{44}$ Leiden became a destination for shearers from Hamburg (and other German port cities) as well. ${ }^{45}$

In the sixteenth century, cloth shearing in Antwerp had developed into an industry based on wage labour in relatively large workshops. ${ }^{46}$ Just like in Amsterdam in the seventeenth century at the Oude Brug (Old Bridge), ${ }^{47}$ there was a regular meeting place for shearers in Antwerp at the Wijngaardbrug (Vineyard Bridge), which functioned as a labour exchange for wage labourers in

goods for the Dutch staple market in the seventeenth and eighteenth centuries.

38 Thijs, Van 'werkwinkel' tot 'fabriek', 172: the number of shearers in Antwerp declined from 1,60o in 1564 to 240 or 260 in 1600; Kaptein, De Hollandse textielnijverheid, 190-191; Gelderblom, Zuid-Nederlandse kooplieden, 64-65.

39 Desmedt, De Engelse natie te Antwerpen, I, 83-84, II, 356; Thijs, Van 'werkwinkel' tot 'fabriek', 62-73.

40 Harreld, High Germans in the Low Countries, 66-67. On the exchange of shearers between Cologne and Antwerp: Thijs, Van 'werkwinkel' tot 'fabriek', 67; on the migration of cloth shearers to Antwerp in general: ibid., 308-313.

41 De Meester, 'To Kill Two Birds with One Stone', 105; Thijs, Van 'werkwinkel' tot 'fabriek', 69.

42 Kleßmann, Geschichte der Stadt Hamburg, 110.

43 Asaert, 1585. De val van Antwerpen, 81-133.

44 Knotter and Van Zanden, 'Immigratie en arbeidsmarkt', 423. On migration of cloth shearers to Amsterdam also: Kuijpers, Migrantenstad, 257-278.

45 Lucassen and De Vries, 'The Rise and Fall', 34.

46 Scholliers, 'Vrije en onvrije arbeiders', 286-287; Thijs, Van 'werkwinkel' tot 'fabriek', 219-223.

47 Knotter and Van Zanden, 'Immigratie en arbeidsmarkt', 411; Dekker, 'Getrouwe broederschap"', 7 . 
Figure 1.3 Cloth shearers in a workshop. Engraving by J.G. van Vliet, Leiden, 1635

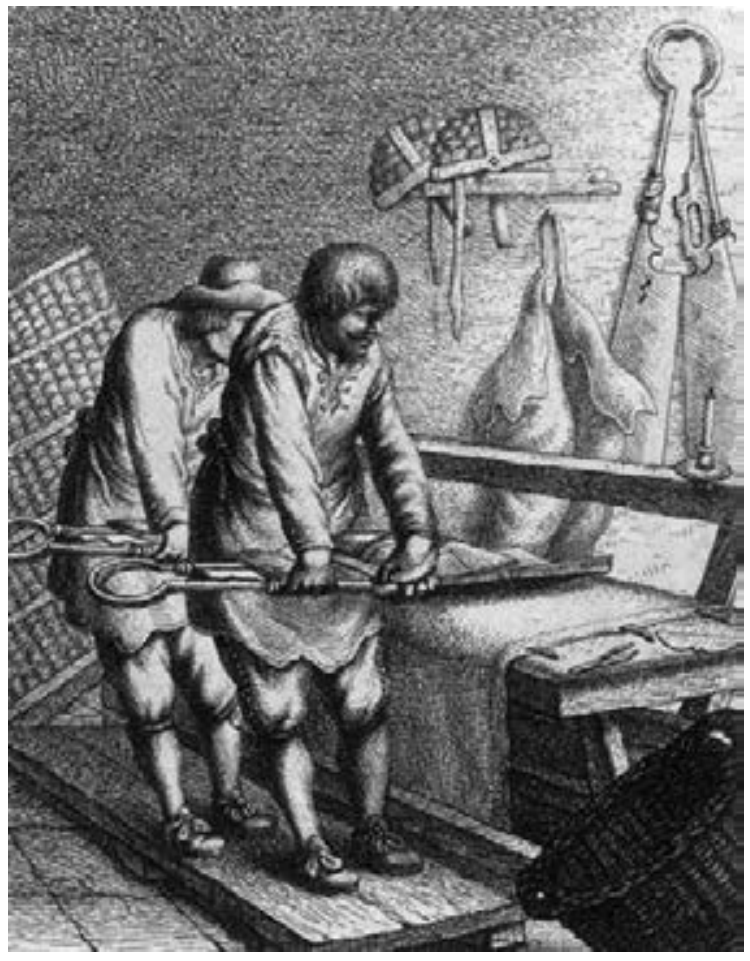

Collection Rijksmuseum Amsterdam

the shearing industry. ${ }^{48}$ Meetings (called 'courts') were held at this place, and strikes were organized from there, for instance in $155^{8}, 1565$, and $1573 / 74$, when the Antwerp shearers used a temporary rise in imports of English cloth to raise their demands for higher wages. ${ }^{49}$ After this last date actions subsided, however, because, according to historian Etienne Scholliers 'the most active elements in the proletariat, especially the Protestants, had moved to the North'. ${ }^{\circ}$

It can hardly be a coincidence that the first complaints about a cloth shearers' 'monopoly' in Amsterdam date from 1591 (Table 1.1), a few years after the migration of the cloth-finishing business from Antwerp..$^{11}$ In 1607 the Amsterdam authorities prohibited meetings, called 'courts' as in Antwerp, of

48 Scholliers, 'Vrije en onvrije arbeiders', 289; see also Thijs, Van 'werkwinkel' tot 'fabriek', 398-414.

49 Ibid., 69; Scholliers, 'Vrije en onvrije arbeiders', 313-315.

50 Ibid., 314 .

51 Dekker, “'Getrouwe broederschap"', 5. Research in the Amsterdam judicial archives from 1578 revealed no collective actions before 1591 . 
Table 1.1 Reported meetings and strikes of cloth shearers in Amsterdam and Leiden, seventeenth-eighteenth centuries

\begin{tabular}{|c|c|c|c|c|}
\hline \multirow[b]{2}{*}{ Year } & \multicolumn{2}{|c|}{ Amsterdam } & \multicolumn{2}{|c|}{ Leiden } \\
\hline & ‘Court' meeting & Strike & ‘Court' meeting & Strike \\
\hline 1591 & & 'monopoly' & & \\
\hline $1607 / 08$ & $x$ & $x^{*}$ & & \\
\hline 1616 & $x$ & & & \\
\hline 1618 & $x$ & & & \\
\hline 1626 & $x$ & & & \\
\hline 1628 & $x$ & $x$ & & \\
\hline 1631 & $x$ & & & \\
\hline 1636 & & $x$ & & $x$ \\
\hline 1637 & & & $x$ & \\
\hline 1638 & $x$ & $x$ & & $x$ \\
\hline 1643 & & & $x$ & $x^{*}$ \\
\hline 1648 & & & & $x$ \\
\hline 1661 & $x$ & & & $x$ \\
\hline 1682 & $x$ & & & \\
\hline 1691 & $x$ & $x$ & & \\
\hline 1692 & $x$ & & & \\
\hline 1700 & $x$ & & $x$ & $x$ \\
\hline 1701 & & & & $x$ \\
\hline 1710 & & $?$ & & \\
\hline 1716 & & & $x$ & \\
\hline 1717 & & & & $x$ \\
\hline 1718 & & & $x$ & $x$ \\
\hline 1724 & $x$ & & & \\
\hline 1732 & & & $x$ & \\
\hline 1737 & $x$ & & & \\
\hline 1741 & & & $x$ & $x$ \\
\hline 1744 & & $x$ & $\mathrm{x}$ & $x$ \\
\hline 1765 & $x$ & $x$ & & \\
\hline 1769 & & & & $x$ \\
\hline
\end{tabular}

* By way of a walk-out from the city.

Sources: Dekker, 'Arbeidsconflicten'; idem, '“Getrouwe broederschap"'; idem, 'Labour conflicts'

shearers, who then walked out of the city to put pressure on the employers. After that date, this kind of 'court' was regularly forbidden, but to no avail. Decisions to strike were made at these meetings, for instance in 1628 when demand for finished cloth was high..$^{2}$ Actions were also coordinated between 
different cities in Holland, especially in 1636-1639, when strikes broke out in both Amsterdam and Leiden, and also in the smaller textile centres of Haarlem, Hoorn, Gouda, and Rotterdam. ${ }^{53}$

After these years, the frequency of strikes in Leiden became much higher than in Amsterdam with clusters in the 1640s, 1700/01, 1717/18, and the 1740 s. In 1700/01 the strikes were about higher wages and were coordinated with a weavers' strike. In May 1701 several meetings were held of some 1,500 to 1,60o strikers (both shearers and weavers), but thereafter the strike passed off without clear results. ${ }^{4}$

In 1716-1718 the Leiden shearers took issue with the introduction of a new shearing device called $k r u k$, imported from England. Working with a kruk was lighter and easier, but the shearers feared that the trade would become accessible for less skilled workers. 'Courts' were held, a general strike broke out, and there was rioting around the house of the employer who had introduced this English device. The shearers succeeded in a boycott against workshops using the kruk. ${ }^{5}$ Called 'crook' in English and mailloche in French, the kruk was a simple wooden lever to ease the heavy manual art of shearing. ${ }^{6}$ Invented in England at the end of the seventeenth century, and being opposed there by shearers as well, it seems to have moved to the continent via Leiden, but it was not universally applied. Just as in Leiden, shearers in Sedan and the Aachen region preferred to stick to the old method to preserve the restricted entry to the trade. As was reported in Sedan:

[The old method], although more laborious and awkward, had been adopted for a long time by the workers only to cause repugnance with apprentices and to prevent a large number [of them]; only finding very few [apprentices], work was abundant, and they could force their law upon the fabricants. ${ }^{57}$

The Leiden strikes of 1741 were again coordinated with Amsterdam and were part of a campaign against the import of cloth that had been partly finished outside Holland, mainly in the Aachen-Verviers region. As the job of shearing was very much reduced in this way, the shearers demanded the

53 Ibid., 15. To combat these coordinated strikes the employers in these cities came together and established an inter-urban employers' union, the so-called droogscheerderssynode: Posthumus (ed.), Bescheiden betreffende de provinciale organisatie.

54 Dekker, 'Arbeidsconflicten in de Leidse textielindustrie', 76.

55 Ibid., 76-77, 80-81.

56 Jarrige, 'Les tondeurs européens', 282-284.

57 Cited ibid., 283. See also Gayot, Draps de Sedan, 126. 
prohibition of the import of finished cloth from the city government. This was the last great strike in Leiden (in 1769 there was one in one workshop only), and a sign that the Leiden industry was in decline. The decline was a consequence of the relocation of production by the Leiden clothiers, partly to the area between Verviers and Aachen. In the second half of the seventeenth century and the first half of the eighteenth, Leiden cloth merchants had moved spinning and weaving increasingly to the Verviers countryside, but at first they continued the finishing of the cloth in Leiden itself..$^{8}$ The strike of the Leiden shearers against the import of semi-finished cloth in 1741 is a clear sign that shearing in the Aachen-Verviers area had developed rapidly, also because clothiers from the area had started to produce fine cloth themselves.

\section{Shearers' strikes and 'manufactural' unionism between the Rhine and the Meuse}

There, across the borders from Verviers to Monschau, from Sedan to Aachen, a particular class of skilled workers was formed, concentrated in large cloth manufactures, 'aggregations of the most dangerous people'. 59

Aachen had been a centre of textile production since medieval times, thanks to its location as a staple town on the trade route between Flanders and Brabant in the west and the Rhineland economic centre of Cologne in the east. ${ }^{60}$ In the sixteenth and seventeenth centuries many Aachen cloth merchants converted to Protestantism. Under pressure of the Catholic authorities in the town, but, as stated by themselves, also to circumvent the restrictions of the guild system in Aachen, Protestant cloth merchants relocated their industrial activities to smaller places in the countryside outside the jurisdiction of Aachen, to Düren, Burtscheid, Eupen, Monschau, Vaals, and their surroundings, where they developed a rural industry. Just like Verviers in the Liège region, these places lacked guild regulations. This enabled cloth merchants to expand production by mobilizing a flexible workforce at the lowest possible cost. In a text dated 1788 , published

$5^{8}$ Posthumus, 'De industrieele concurrentie'. As a consequence, in the seventeenth century very few shearers migrated to Leiden from this area: Lucassen and De Vries, 'The Rise and Fall', 34.

59 Gayot, 'La longue insolence', 130.

60 For the Aachen textile industry: Kisch, 'Das Erbe des Mittelalters'; Ebeling, 'Entstehungs- und Existenzbedingungen'; Ebeling and Schmidt, 'Zunftige Handwerkswirtschaft'. 
anonymously but written by the large Aachen cloth manufacturer Von Clermont, this was mentioned as a great advantage:

\begin{abstract}
All around [Aachen] in Burtscheid, Monschau, Verviers, Vaals, and the whole of industrious Limburg, freedom rules; the cloth merchant [...] can develop his industry freely and choose his workers and their numbers as he likes. The free imperial city [of Aachen], by contrast, is governed by a very harmful compulsory guild system. ${ }^{61}$
\end{abstract}

From the early 1700s Aachen entrepreneurs, including the Clermonts, employed spinners and weavers in the Dutch Republic's enclave around Vaals, close to Aachen. ${ }^{62}$ In 1761 Von Clermont moved his company across the border to Vaals, to circumvent the Aachen regulations. In his 1788 text he explicitly mentioned the advantages of employing workers outside the city without restrictions, also as a means to deter and improve the behaviour of 'bad elements' in the city itself. ${ }^{63}$

Although whether the guilds had a negative impact on the development of urban industries like those in Aachen can be questioned, if only because their rules were flexibly adapted and circumvented, ${ }^{64}$ merchant-entrepreneurs used the regulations imposed by the guilds as a pretext to relocate production to the countryside. In the new centres of textile industry between Liège and Aachen they were free to employ labour according to their needs. In this way they could expand more easily and adapt their labour force to changing demands and the fluctuations of the trade. The unrestricted freedom to employ workers at will had been one of the main reasons for the Leiden merchants to turn to the Verviers region for spinning and weaving as well. ${ }^{65}$ 'Absolute freedom of manufacturing, this is, in my view, during the old regime, the main characteristic of the Verviers industry', wrote the historian of the Verviers cloth industry, Pierre Lebrun. ${ }^{66}$ The reverse of this condition was that textile workers in this area were completely unprotected against the vagaries of the market. No wonder that in these new textile

61 Freymüthigen Betrachtungen eines Weltbürgers zum Wohl von Aachen bey Gelegenheit der bevorstehenden Konstitutions-Verbesserung dieser Stadt (1788), cited by Dahmen, Das Aachener Tuchgewerbe, 86.

62 Hovens, 'De komst van lakenfabrikant Johann Arnold Clermont'.

63 Cited by Ebeling and Schmidt, 'Zünftige Handwerkswirtschaft', 333-334.

64 Ebeling, 'Entstehungs- und Existenzbedingungen', 111-114, criticizing Kisch, 'Das Erbe des Mittelalters'.

65 Posthumus, 'De industrieele concurrentie', 371.

66 Lebrun, Industrie de la laine, 102. 
Figure 1.4 Cloth shearers working with a crook or mailloche in their right hands. Engraving, France, seventeenth century

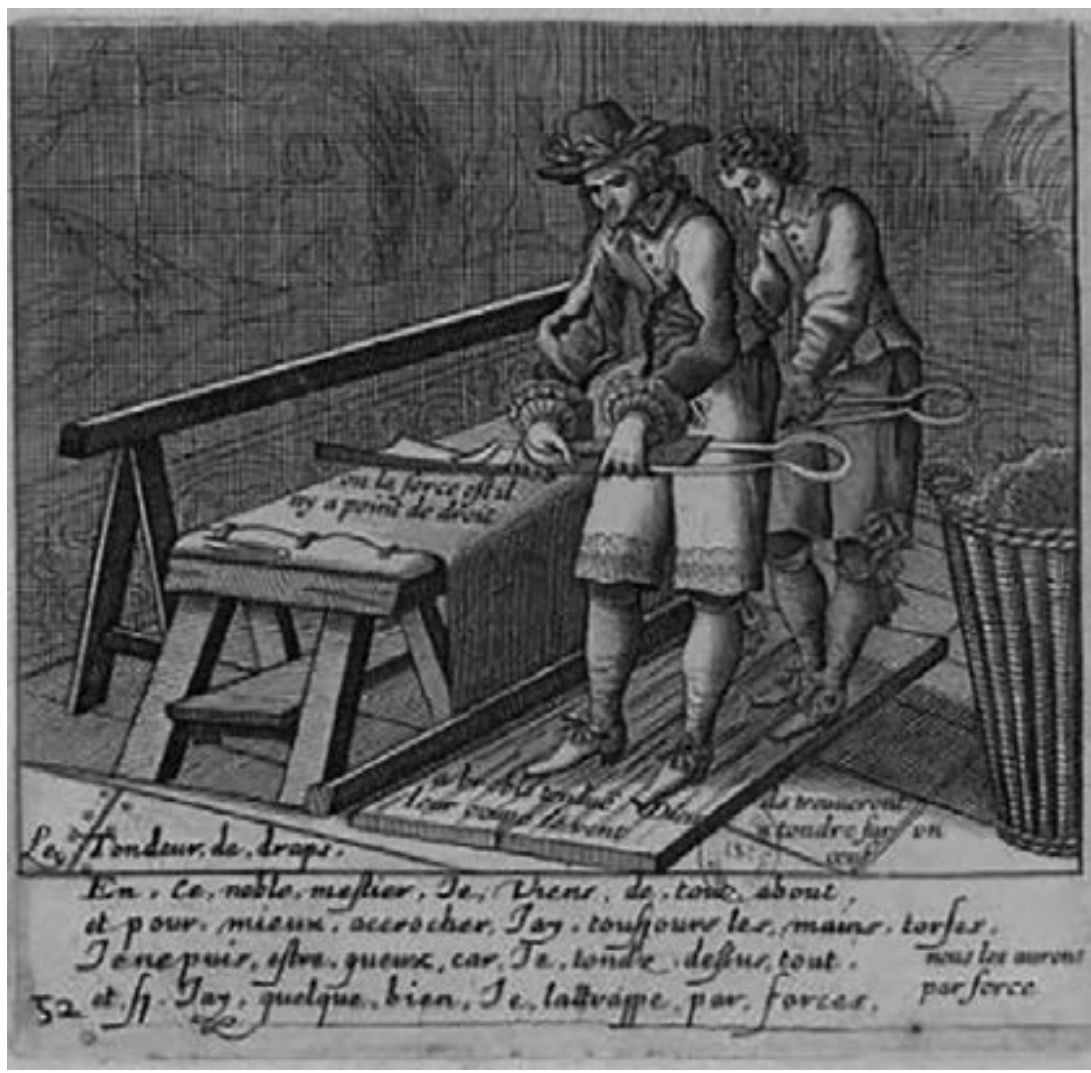

Bibliothèque National de France: Collection Michel Hennin. Estampes relatives à I'Histoire de France. Tome 42, Pièces 3734-3885, 1656-1657. Used with permission

centres control of the labour market became the main issue in a series of industrial conflicts by weavers, ${ }^{6} 7$ but predominantly by cloth shearers.

Like everywhere in north-western Europe cloth shearers were the most militant among the textile workers. They did not work in the countryside, but in centralized buildings in the centres of textile manufacturing in the

67 On several occasions local weavers in Verviers (1739, 1741, 1789), Aachen/Burtscheid (1757), and Monschau (1774) agitated against work being awarded to rural weavers in Limburg and Vaals. Verviers: Fairon, 'La question ouvrière', 43-44; idem, 'Les industries du Pays de Verviers', 36-37; Lebrun, Industrie de la laine, 218, 258-259. Aachen/Burtscheid: Hovens, 'De komst van lakenfabrikant Johann Arnold Clermont', 234-238. Monschau: Barkhausen, Die Tuchindustrie, 98-102; Henkel and Taubert, Maschinenstürmer, 92-96. 
Table 1.2 Number of cloth shearers in industrial centres in the Meuse-Rhine region, around 1800

\begin{tabular}{lc}
\hline Town & Number of shearers \\
\hline Aachen & 698 \\
Burtscheid & 205 \\
Monschau & 317 \\
Imgenbroich & 83 \\
Eupen & 489 \\
Verviers & 700 \\
Sedan & 800 \\
Total & 3,292 \\
\hline
\end{tabular}

Source: Gayot, 'Les "ouvriers les plus nécessaires"', 215

region, often attached to the homes of merchants, who could then supervise this crucial process in cloth production themselves. ${ }^{68}$ Table 1.2 gives an overview of the number of shearers employed in the different textile centres in the Meuse-Rhine region around 1800.

In the literature on the cloth industry in this area, including Sedan, I counted 28 shearers' strikes in the eighteenth century (see Table 1.3). That industrial conflict and workers' insolence were quite normal can be deduced from the many and surprisingly similar formulations of regulations against them (see Appendix 1.1). These regulations show that the peculiar repertoires of collective action by cloth shearers described by Dekker for the Dutch cases could be found here as well: the instigators moved from workshop to workshop, declaring shops or workers who would not join 'foul' (sale, pourrie, faul, schmutzig), slandering and abusing them (schimpfen, schelten, schmähen), under threat of having to pay for or provide a fricasse, Saufpott, or etlichen Tonnen Bier. We can also note the fear of the authorities of workers assembling: they all rule against tenir assemblées; zu versammeln oder zusammenzurotten; de s'assembler ou attrouper; unzulässige Zusamenkombsten zu halten; zu Zusammenkünften sich aneinanderschließen.

From different reports on the strikes it appears that the shearers' repertoires of contention were very much alike: they roamed through town to urge fellow workers to stop working by using ritual words of abuse, and sometimes

68 Some of these can still be admired as tourist attractions, like Das Rote Haus in Monschau of cloth merchant Scheibler: Mangold, 'Aufstieg und Niedergang der Tuchindustrie'. Arguments by Scheibler in favour of the concentration of shearing in his own premises against subcontracting to small masters can be found in Barkhausen, Die Tuchindustrie, 113-117. 
Table 1.3 Shearers' strikes in Sedan and in the Meuse-Rhine borderlands in the eighteenth century

\begin{tabular}{|c|c|c|c|c|c|c|}
\hline Year & Sedan & Aachen & Eupen & Monschau & Verviers & Burtscheid \\
\hline 1700 & & $x$ & & & & \\
\hline 1705 & & $x$ & & & & \\
\hline 1712 & $x$ & & & & & \\
\hline 1713 & $x$ & & & & & \\
\hline 1715 & & & $x$ & & & \\
\hline 1721 & & & $x$ & & & \\
\hline 1722 & & & $x$ & & & \\
\hline 1729 & $x$ & & & & & \\
\hline 1738 & $x$ & & & & & \\
\hline 1742 & & & & $x$ & $x^{*}$ & \\
\hline 1743 & & & & & $x$ & \\
\hline 1747 & & $x$ & & & & \\
\hline 1748 & $x$ & & & & & \\
\hline 1750 & $x$ & & & & & \\
\hline 1753 & & $x$ & & & & \\
\hline 1757 & & & & & $x^{*}$ & $x$ \\
\hline 1759 & & $x$ & & & $x$ & \\
\hline 1761 & & & $x$ & & & \\
\hline 1762 & & & & $x$ & & \\
\hline 1763 & & & & $x$ & & \\
\hline 1765 & & $x$ & & & & $x$ \\
\hline 1781 & & & & & $x$ & \\
\hline 1797 & & & & $x$ & & \\
\hline 1798 & & & $x$ & & & \\
\hline
\end{tabular}

* Hodimont

Sources: Kermann, Die Manufakturen im Rheinland, 122; Ebeling and Schmidt, 'Zünftige Handwerkswirtschaft', 331-333; Gayot, 'La longue insolence', 114-116; Gayot, Draps de Sedan, 210214; Dechesne, L'avènement du régime syndical, 52-53, 59-60; Hermanns, 'Die Tuchscherer', 154, 164-167; Henkel, 'Taglohn, Tradition und Revolution', 51-55; Fairon, 'La question ouvrière', 45-47; Barkhausen, Die Tuchindustrie, 80-85, 151-153; Lebrun, L'industrie de la laine, 259-260; Beiträge und Material, 88, 258-259, 325; Dechesne, Industrie drapière, 209; Kisch, 'Das Erbe des Mittelalters', 286-287; Reith, Lohn und Leistung, 152-153; Schmidt, 'Burtscheid um 1800', 85; Schnock, 'Über gewerbliche Verhältnisse', 38-40; Minke, 'Arbeiterunruhen', 107-109

also violence, held assemblies inside or outside town, chose representatives to negotiate with employers and/or authorities, and sometimes sent requests or petitions to the authorities. There are also instances of organizing a kind of trade union. The most remarkable example is the Confraternité entre les tondeurs de la ville de Verviers, d'Ensival pays de Liège, du faubourg de Hodimont et de Francomont (Brotherhood between the cloth shearers of the city of Verviers, of Ensival [in] the country of Liège, of the suburb of 
Hodimont and of Francomont), established during the great strike of the Verviers shearers in 1759 (see below), with a kind of strike fund, a caisse de la mutualité établie par le corps de metier ('a mutual fund established by the body of craftsmen'). ${ }^{69} \mathrm{~A}$ fund (Cassam) was also mentioned in an Aachen resolution of 1746 (cited in Appendix 1.1), the formation of a corps or confrairie was prohibited in Sedan in 1748, and the Burtscheid decree of 1767 forbade das Aufstellen von Statuten (drawing up a constitution).

For the employers and authorities the issue was clear: they wanted absolute freedom to hire whomever they wanted, under conditions they decided themselves. The Eupen Ordonnantie weghens de Droogscherersgasten in 1724 stated that no locally based shearer was allowed to refuse cooperation with incoming people. The charter of the employers' Feine Gewandschaft in Monschau in 1742 was most explicit. They decided among themselves that they would employ

all and every journeymen, apprentices or women, whoever would serve them, just like in Verviers and elsewhere, as is common in our duchy of Jülich and Berg where there are no guilds, wherever the workers may come from, from east or west, from south or north, from clean or foul workshops, or how these may be called elsewhere..$^{0}$

The shearers, by contrast, wanted to control the number and conditions of employment of fellow workers, both incoming migrants and apprentices. In nine of 28 cases they protested against an enlargement of the number of apprentices by the employers circumventing customary regulations, in eight against the employment of unqualified outsiders, sometimes specifically identified as 'Protestants' or 'foreigners'. The strikers clearly wanted to have a say in the appointment and qualifications of new workers to control labour supply. In other cases strikes concerned wage levels or working time. Below, I have selected some of the most significant industrial conflicts as examples.

\section{Sedan 1748-1750}

In Sedan there had been difficultés et différends between clothiers and shearers, sometimes resulting in petites cabales or mutineries, since at least

69 Lebrun, Industrie de la laine, 261; Dechesne, Industrie drapière, 209-212. According to Fairon, 'La question ouvrière', 47, this was 'the oldest trade union established in our region'.

70 Henkel and Taubert, Maschinenstürmer, 88; Barkhausen, Die Tuchindustrie, 81-82. 
Figure 1.5 Map of the centres of cloth production in Northwestern Europe and years of strike actions between 1588 and 1830

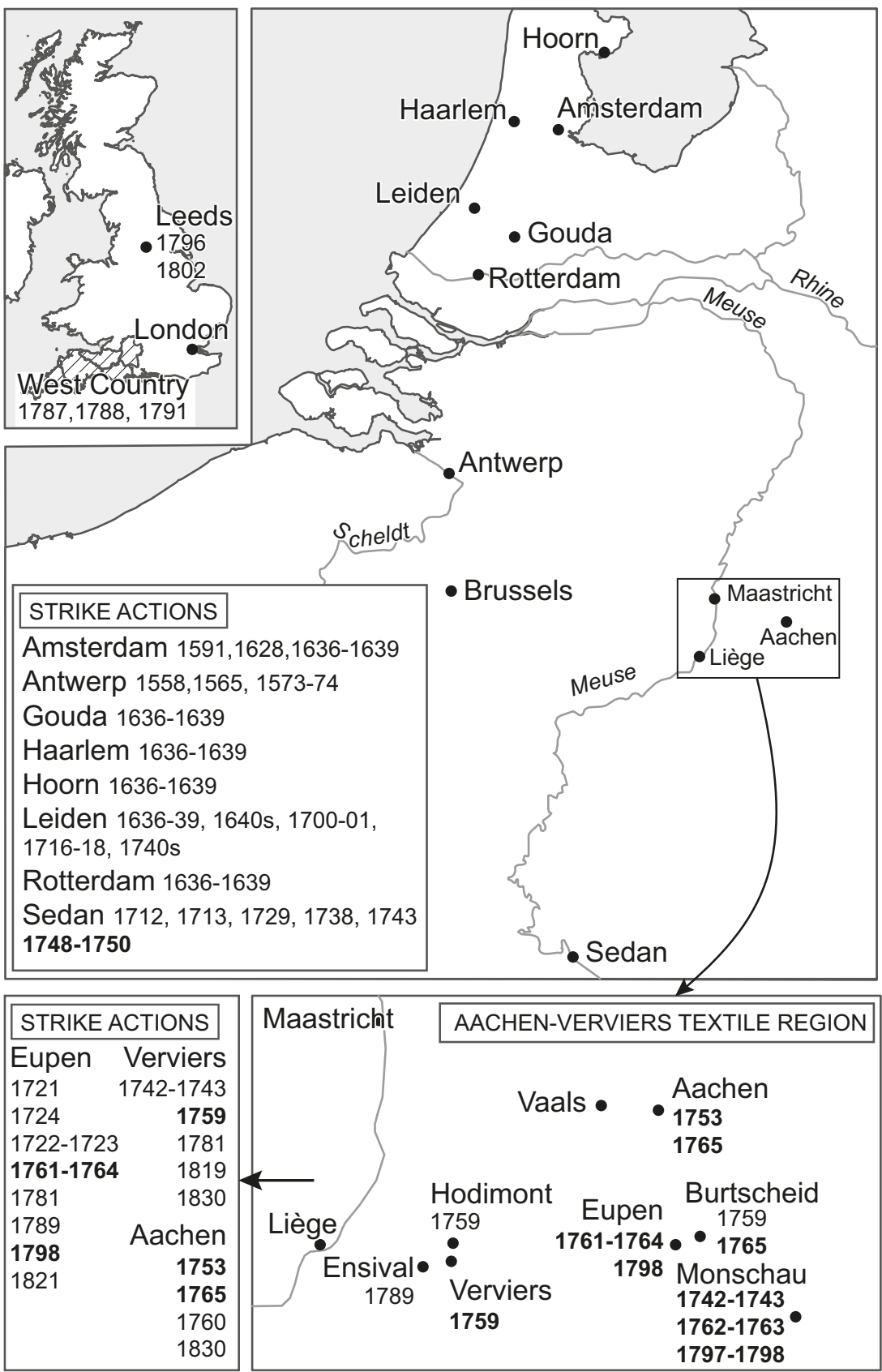


$1698 .^{71}$ In that year a government ordonnance had regulated the number of apprentices in a way that suited both masters and journeymen, but at the time shearing was still predominantly subcontracted by small masters. The growth of the industry and the concentration of shearing in larger workshops created a need for more recruits; therefore the employers wanted to employ more apprentices than allowed. They met with fierce resistance by the shearers. Conflicts over wages and working time arose as well. Gérard Gayot reported about cabales in 1712 (a strike by 400 over wages), in 1713 (over the number of apprentices), in 1729 (over wage deductions by an employer), and in 1738 (over the employment of unqualified workers). When in 1743 a new regulation was issued permitting employers to use as many apprentices as they wanted, there was no strike, but a large number of Sedan shearers 'walked out' to Verviers, where their arrival at first met with opposition by local shearers until it was ruled that only apprenticed shearers from abroad were allowed to work in the Verviers workshops. ${ }^{72}$

These were only harbingers of the grande colère des tondeurs in Sedan in 1748 and $175^{\circ}$. The 1748 strike was directed against the large employers wanting to involve the shearers in tasks other than shearing and lasted 24 days (from 14 October to 6 November). After this strike orders were issued by the Conseil d'État du Roi prohibiting workers from organizing in a corps or confrairie or from obstructing the freedom of the employers choosing their workers freely - skilled craftsmen or others, French or foreign - in the numbers they deemed necessary. ${ }^{73}$ This enabled the employers to recruit at will, and to prevent this happening the shearers staged another strike from 1 August $175^{\circ}$ onwards. Employers' agents were sent to Verviers to recruit strike breakers there, but they only partly succeeded, as the strikers sent agents as well to prevent them coming. ${ }^{74}$ The strike lasted forty-three days, until 14 September 1750, when the leaders were arrested and banned or fined.

This was not the end of workers' organizing in Sedan, however. A 1803 report described the Sedan shearers as, 'without doubt an aggregation of the most dangerous men':

Although divided in 26 or 30 'factories' [fabriques], these men form a most effective coalition. In each workshop they choose a speaker [orateur] charged with local affairs at the workshop, and, acting as a representative 
[commissaire] of this workshop from the moment when action by the coalition is needed [...], it [the coalition] acts with great precision, escaping government supervision. Recently, the shearers demanded a pay rise [...] which was accorded. Since 1788, and to perpetuate their vexatious influence, they have not permitted the manufacturers to place an apprentice, and to the extent of natural deaths among them, for fifteen years the number of cloth shearers has fallen. [...] From the moment when a manufacturer tries to train an apprentice they have not approved, all the cloth shearers make what they call a cloque [...] and stop work. They receive from the other workers enough money to survive until the refractory manufacturer voluntarily agrees to remove the apprentice they did not wish to accept. ${ }^{75}$

\section{Verviers 1759}

Already in 1724 the Verviers shearers had founded a bourse for mutual assistance, which is said to have functioned as the principal centre of workers' resistance in the region during the eighteenth century. ${ }^{76}$ The Confraternité entre les tondeurs mentioned earlier, established during the strike of 1759 , was presented by its founders as a rénovation of this bourse ${ }^{77}$ Like elsewhere, shearers in Verviers tried to gain control over the employment of apprentices and foreigners. Shearers from the Liège territory and those from the duchy of Limburg were not allowed to work in each other's workshops unless there was a shortage of labour. As a consequence, even the shearers of Verviers (in Liège) and Hodimont (in Limburg), separated by the border river Vesdre at a distance of only five kilometres, mutually excluded each other.$^{7}$ However, in 1743 those from Verviers and Hodimont together turned against newly arrived immigrants, primarily from Sedan (see above).$^{79}$ The Confraternité entre les tondeurs encompassed shearers from Hodimont, and the Eupen shearers were invited to join as well.

When a decree issued from Brussels in 1743 prescribed a limitation of apprentices and a minimum duration of their training in the duchy of Limburg (therefore in Eupen and Hodimont), the Verviers shearers tried to

75 Mourgue, Rapport au Ministre de l'Intérieur; my citation combines quotations by Gayot, Draps de Sedan, 423, and Horn, The Path Not Taken, 208.

76 Dechesne, L'avènement du régime syndical, 52.

77 Ibid., 60 .

78 Notices historiques sur le pays de Liège, 128 (a digitized version can be consulted on Google books).

79 Dechesne, L'avènement du régime syndical, 52-53; Lebrun, Industrie de la laine, 259-262. 
enforce this as well, but the Verviers manufacturers and authorities kept stubbornly refusing their demands on this issue; a minimum wage of 20 sols a day was prescribed, however. ${ }^{80}$

The 1759 strike in Verviers, the longest in the region as a whole, was not primarily about employment control, but about wages, more specifically about the exchange rate of the money these were paid in. ${ }^{81}$ As the Verviers merchants sold most of their cloth at annual fairs in Germany, a lot of German money was circulating in Verviers. Wages were paid in German currency, not according to the official Liège exchange rate, but to the current German rate, which was about 20 per cent higher. Money was abundant in Liège, and therefore cheaper, because of the many trade relations with prosperous Holland via the river Meuse. ${ }^{82}$ As a consequence, after exchange of their wages in local Liège currency, workers had only eighteen instead of the prescribed twenty sols to spend in the local market. This was highly profitable for the cloth merchants, who were even said to deliberately exchange 'good' for 'bad' money in Aachen to pay the wages. ${ }^{83}$ The argument of the Verviers merchants against using the official exchange rate was that cloth manufacturers in other textile centres outside the Liège region (Eupen, Aachen, Burtscheid, Monschau), where German money was regularly used and workers were paid at the German rate, would gain a competitive advantage on the common German sales market.

The strike was launched when business was booming, so at an appropriate moment to put pressure on the employers. The shearers demanded pay at the official Liège exchange rate, and also a regulation of apprenticeship. On the morning of 26 June 1759 ,

a great number [of workers], led by delegates Jean Leclerc, Simon Thiry, Jean-Joseph Lafontaine, and Léonard de Ponton, assembled at the Market place and swore that work would not be resumed until justice was done. Then the mutineers disbanded into several groups, circulating through all of the town, shouting and wreaking havoc, and spreading alarm everywhere by menacing and ranting. They invaded the workshops, forcing everybody to stop working and join them, under threat of being mistreated [and also by destroying the shearers' tools]. ${ }^{84}$

80 Ibid.; Fairon, 'La question ouvrière', 45; Notices historiques sur le pays de Liège, 129-130.

81 There is a detailed account of the strike ibid., 124-147: chs. CCLXV-CCLXXI; see also Dechesne, L'avènement du régime syndical, 46-47.

82 Haesenne-Peremans, La pauvreté dans la région liégeoise, 321-322 and 264.

83 Ibid., 26o; Janssens, Het geldwezen der Oostenrijkse Nederlanden, 189-19o.

84 Notices historiques sur le pays de Liège, 131. 
During the strike, petitions, notes, memoranda were exchanged with the prince-bishop in Liège, whose interventions were to no avail, however. A large meeting on 3 July decided to continue the strike, and now the Verviers weavers became involved too, bringing the whole industry to a standstill. Strikers continued to roam the streets and were again reported to have destroyed the strike breakers' shears to prevent them from working. The strike ended on 3 September 1759, so after nine weeks, with a compromise, which forced the employers to pay wages at the official exchange rate, but did not interfere in their freedom to employ and train apprentices. The shearers continued agitating against this freedom in the Confraternité entre les tondeurs, which, in spite of being regularly prohibited by the authorities, seems to have existed until at least $1781 .{ }^{85}$

\section{Monschau 1742-1743, 1762-1763, 1797}

The production of fine cloth in Monschau was initiated in the 1730 s by the Protestant merchant Johann Heinrich Scheibler, and in the following years the industry started to expand, also as a consequence of several of his relatives setting up new firms. Spinners and weavers could be found in Monschau and surroundings, because an industry of coarse cloth existed there already, but this kind of cloth did not require finishing by shearing. For the production of fine cloth shearers had to be attracted from outside the region. They brought the customs and traditions of the trade with them, and started to demand limits on the number of apprentices and the recruitment of new workers, to gain influence on wage levels, and to call for the exclusive employment of skilled shearers. The clothiers fiercely opposed these demands: to enable the industry to grow they wanted to employ as many apprentices and workers as they liked. In 1742 they united in a society called Feine Gewandschaft, which issued the charter cited in Appendix 1.1 against all intrusions into their freedom of hiring people. In the following year industrial conflicts arose over this issue on several occasions, until on 17 March 1743 the workers gave in, and a contract was signed by fifty-six shearers as representatives of the shearers' body as a whole (only twenty-one could write their signature themselves).

Twenty years later the issue of labour market control was reason for yet another conflict. The industrialists had recruited (mainly Protestant) shearers and their families from inland Germany, to the extent that two-thirds of the labour force consisted of migrants. In 1762 a strike was organized (in which 
migrants also participated) in several workshops demanding a restriction of the number of apprentices at each shop, priority employment of shearers from Monschau itself, and a wage rise of 10 per cent. In December the conflict culminated in a general strike and riots against newly arrived Protestant migrants, which could be suppressed only by the central government sending in the military. Social and religious motives went hand in hand here, as the striking shearers were supported against the large Protestant manufacturers of fine cloth by the smaller Catholic merchants selling coarse cloth, who dominated the Monschau town government. In the end, in 1763, the strikers achieved a wage rise, but were not able to enforce employment control. ${ }^{86}$

In 1797 the number of apprentices again became the reason for a strike, which was also coordinated with Aachen, and with the smaller textile centres of Düren, Imgenbroich, and Stolberg. The strikers tried to involve their Eupen colleagues as well, but the latter preferred to stand for their demands on their own (see below). ${ }^{87}$

\section{Aachen 1753 and 1765}

In the eighteenth century, guild regulations in Aachen limiting the number of journeymen per master did not prevent cloth merchants from concentrating shearers in large workshops ${ }^{88}$ In 1746 their insolence apparently had become a nuisance, as the authorities issued a decree prohibiting all forms of industrial action (see Appendix 1.1). This did not prevent a strike, however, which had demands that we do not know. In 1753 a conflict arose over workers being allowed by the city magistrate to work in a large new workshop set up by the cloth merchant Heupgen, which was then declared faul. Precisely when production for the Frankfurt and Leipzig fairs was busiest, a strike was called. An eyewitness wrote:

On the 12th of March they take a drum and go with it through the city to Burtscheid and involve fellow workers there too, and then return to the city and make a great revolt with their drum and cries, mingling with all kind of riffraff, namely woollen weavers and needle makers, spinners and all sorts of wild people. ${ }^{89}$

86 Barkhausen, Die Tuchindustrie, 86-96; Henkel and Taubert, Maschinenstürmer, 88-92; Kisch, 'Das Erbe des Mittelalters', 285-288.

87 Barkhausen, Die Tuchindustrie, 151-153; Minke, 'Arbeiterunruhen', 109-111.

88 Kermann, Die Manufakturen im Rheinland, 118-13o.

89 Beiträge und Material, 198. 
After ten days, the city magistrate gave in. The striking shearers 'are happy, come full of joy together, take musicians with them and go around the city and make merry the whole night. [...] The next day all returned to work again.90 In 1759 a strike was reported in the form of a collective walk-out from the city to pick up work in Burtscheid, ${ }^{91}$ and another in June 1765 about a wage rise, $9^{22}$ perhaps infected by industrial unrest in nearby Burtscheid in that same year.

\section{Burtscheid 1765}

Burtscheid, situated right at the walls of Aachen (it is now incorporated in the city), had a different (industrial) regime, but the industries in both places were in fact closely related. Aachen had not been able to prevent the relocation of part of its woollen industry to Burtscheid. Centralized shearers' workshops had been established there at least since the end of the seventeenth century, ${ }^{93}$ partly by Protestants fleeing the strict Catholic regime in Aachen. As elsewhere, religious conflict easily mixed with the aim of controlling the labour market, as in the case of shearers protesting against a workshop established in Burtscheid by the Aachen protestant Wilhelm Ludwig in 1765 . On the 11th of January 1765 shearers from Aachen and Burtscheid assembled and raided Ludwig's house and workshop, smashing and destroying all that was inside: 'slashed the table, shears, bank, panels of the said master all in pieces and threw all of it out of the window, and were very insolent'. ${ }^{94}$ Apparently a strike was called: non-strikers were threatened with 'having their arms and legs broken', and strikers were promised financial support, ${ }^{95}$ although it remains unclear where this money came from. The insolence went on until 1767 and was subdued only by calling in military assistance and arresting the ringleaders. A decree to prevent further unrest was issued by Das Burtscheider Gericht in April 1767 (cited in Appendix 1.1), and somewhat later the employers were officially allowed to recruit journeymen from wherever they wanted: 'from Breslau, Danzig, Verviers, Monschau, Maastricht and other places' ${ }^{\prime 6}$

90 Ibid., 199 .

91 Mentioned in Reith, Grießinger, and Eggers, Streikbewegungen deutscher Handwerksgesellen, 160-161.

92 Ibid., 182-183; Beiträge und Material, 326-327; Reith, Lohn und Leistung, 152-153.

93 Kermann, Die Manufakturen im Rheinland, 132; Schmidt, 'Burtscheid um 180o', 25.

94 Schnock, 'Über gewerbliche Verhältnisse', 38 ; Beiträge und Material, 325. See also Schmidt, 'Burtscheid um 1800', 25-26.

95 Schnock, 'Über gewerbliche Verhältnisse', 39.

96 Ibid., 40. 
Meanwhile Wilhelm Ludwig, who had been the cause of all this trouble, had moved across the border to Vaals, where he finally was able to establish his workshop. On 29 August 1765 he obtained a decree from the judicial authorities in Vaals, corroborating an Ordnung und Einrichtung für die Knechte welche aufdem Winkel von Meister Hermann Wilhelm Ludwigs in Vaals arbeiten gedenken (Regulation and Design for the Journeymen who Intend to Work at the Workshop of Master Hermann Wilhelm Ludwig in Vaals). It ordained (among other things) that the decision about who was allowed to be employed 'must only depend on the opinion of the master, but in no way on the judgement of the journeymen already present in the workshop, who would not ever want to work with any other workman whatsoever from any country whatsoever'. ${ }^{97}$ A similar regulation was issued two years later for the manufacture of Von Clermont in Vaals. ${ }^{98}$

\section{Eupen $1761-1764$ and 1798}

In Eupen, industrial conflict was just as endemic as in other places; collective action was reported there already in 1722-1723, followed by an official decree against it in 1724 (see Appendix 1.1). A norm of two apprentices at each workshop seems to have been applied. ${ }^{99}$ When in October 1761 a third apprentice was appointed in two workshops, shearers entered these shops and in a loud voice forbade those present to continue working. Shearers organized underground meetings and established a fund with the aim of starting legal action. Between 1762 and 1764 unrest continued. In 1764, in a petition to the Limburg authorities the Eupen shearers complained about arbitrary wage payment and unfavourable exchange rates (as in Verviers), and requested new government regulation on labour supply, a wage rise, and inspection by the authorities to control its observance. ${ }^{100}$ The negative answer by the Limburg authorities has already been cited in the introduction: such a regulation would in their view give a competitive advantage to merchants in other textile centres in the region not subjected to the Limburg laws.

From 1724, the Eupen shearers habitually chose six representatives (voorstaenders) from each workshop to negotiate collectively with the

97 Regionaal Historisch Centrum Limburg (RHCL), arch. Landen van Overmaas (01.075), inv. nr. 9446: Civile Rolle der Hoofdbanken Holset, Vaals en Vijlen, 1755-1769, 29 August 1765.

98 Ibid., 15 January 1767.

99 Henkel, 'Taglohn, Tradition und Revolution', 50-53.

100 Ibid., 55-56; Dechesne, Industrie drapière, 213-214; Hermanns, 'Die Tuchscherer', 160. 
employers. ${ }^{101} \mathrm{~A}$ 'corporation' is mentioned as well. ${ }^{102}$ There is proof of legal action and petitioning on behalf of the shearers in the early 1760 , less of open labour unrest. In 1790 a kind of collective contract was signed without industrial action. ${ }^{103}$ In 1798 , however, the issue of a third apprentice did become reason to strike. On 9January, shearers walked out of at least sixteen workshops where a third apprentice had been taken on, obliging co-workers in other workshops to join:

they flutter from one pub to another, getting drunk and cursing the manufacturers. Dissatisfied, they entered several workshops this morning, and demanded that various other shearers still working follow their example; others have gone to the imperial forest to steal wood. ${ }^{104}$

The number of strikers amounted to 90o. On 13 February the strike ended with a negotiated compromise on a wage rise, the acceptance of three apprentices per workshop, and the establishment of a sick fund..$^{105}$

\section{Conclusion}

In his monumental study of strike movements by German journeymen in the eighteenth century, Andreas Grießinger concluded that their strikes were 'determined' by an 'accumulation of symbolic capital of honour', which enabled them to interact and unite effectively and to control production as producers. This 'symbolic capital' became obsolete and control was lost when labour became involved and was recruited in a 'free labour market'. ${ }^{106}$ The cloth shearers' strikes in north-western Europe in the eighteenth century do not fit into this mould. While using dishonouring language in declaring workers or workshops 'foul', ${ }^{107}$ these strikes were not in defence of 'honour',

101 Henkel, 'Taglohn, Tradition und Revolution', 53. In 1798 we know their names from two different sources, as they were summoned as strike leaders: Michel Claassen (Michel Joseph Clesgens), Heinrich Breul (Heindrich Brüll), Thomas Beck (Thomas Beek), Hene Emons (Stephan Emonds), N. Momber (Nikolaus Momber), Adam Wittekent (Adam Wittekind): Hermanns, 'Die Tuchscherer', 164; Minke, 'Arbeiterunruhen', 110.

102 Ibid., 115.

103 Henkel, 'Taglohn, Tradition und Revolution', is devoted to the 1790 collective agreement.

104 Cited by Minke, 'Arbeiterunruhen', 107; see also Hermanns, 'Die Tuchscherer', 164.

105 Minke, 'Arbeiterunruhen', 118-119.

106 Grießinger, Das symbolische Kapital der Ehre, 455-456. For a comparable emphasis on honour to define artisan attitudes: Farr, Artisans in Europe.

107 Ibid., 199. 
but predominantly of 'skill' (as defined through apprenticeship). They were aimed at controlling the labour market to protect this skill, precisely in situations where labour market control was lacking as a result of deliberate policies by employers and local authorities. I tend to follow John Rule here, who argued that the most significant of values and assumptions which underlay the consciousness of eighteenth-century skilled workers was their sense of possessing a 'property of skill', which entitled its holders to dignity and respect, both from fellow workers and employers. The notion of 'honour' can be applied only if it is understood as a manifestation of this sense. ${ }^{108}$ To cite Rule:

the conflict was not simply between moral rights and market determination. These wage-earners accepted that bargaining was one of the processes that determined what they were paid for selling their particular labour power, but they did not accept that it should take place in an open, unregulated labour market. ${ }^{109}$

Cloth shearers' strikes became regular manifestations of insolence when shearing by small subcontracting masters was replaced by workshops employing relatively large numbers of waged workers. The form and content of industrial action by the shearers were perfectly congruent with the 'period of manufacture', situated by Marx between independent handicraft production and the age of 'machino-facture' after industrialization. ${ }^{110}$ I see no linear continuity in strike behaviour by the shearers with nineteenthcentury industrial unionism, nor a linear development from pre-industrial 'proto-unionism' to modern forms of organizing, but a particular kind of 'manufactural unionism', as a variety of its own, attached to this period of manufacture. The characteristics of this variety are given by John Rule in his studies on eighteenth-century British trade unionism in defence of skill as a collective property of the manufacturing workers. For these workers, regulation of apprenticeship was crucial, to define or defend skill and to control labour supply as a means of upholding wages. To achieve that goal they also agitated against the employment of 'foreigners' and 'outsiders', as migratory behaviour of shearers was a defining characteristic of the trade.

108 Rule, 'The Property of Skill', 104, 108. It is important to note here that 'skill' is not an attribute that can be measured objectively, but could be defined only through (the protection of) apprenticeship.

109 Idem, 'Review Essay: Proto-Unionism?', 144.

110 Idem, 'The Formative Years', 3. 
Perfectly aware of their collective power, they used market opportunities to put pressure on the employers to enforce wage rises and other improvements.

In the cases studied, subcontracting by small master shearers, employing only one or two helpers or apprentices, had become obsolete. In some cases shearing had developed into a workshop industry with several dozen workers per workshop, while in others it had been like this from the beginning. As long as labour depended on manual skill and there were no shearing machines involved, there were few reasons to further centralize labour in factories. In each textile centre there were several workshops operating: in Eupen, for instance, at least sixteen workshops were mentioned, and in Sedan as many as twenty-six to thirty (see above). To effectively organize strikes, the organizers had to involve workers in all of these workshops. As a consequence, strikes inevitably took on a public character, with general meetings in market squares, pubs, or open fields outside town, and strikers roaming through town and entering workshops to incite fellow workers, in extreme cases even to the extent of destroying their tools. Elite observers and authorities considered these public actions 'riots', and, following their judgement, we may be tempted to call the shearers' action repertoire a kind of 'collective bargaining by riot', but that is only part of the story.

Eric Hobsbawm, who coined the term in his $195^{2}$ pioneering essay on 'The Machine Breakers', explicitly referred to the so-called Wiltshire Outrages of 1802 by shearers in the West Country of England, ${ }^{111}$ but Adrian Randall later showed that these outrages were a result of effective trade union organization in the so-called Brief Institution. The outrages were in fact a culmination of more regular industrial organizing and action. They were preceded by several contests over apprenticeship, of which a strike in September 1802 at the large Leeds woollen manufacture of Benjamin Gott was the most significant. It turned into a general showdown with the Leeds merchants, which could be sustained by the shearmen thanks to their strike fund, and ended on 18 January 1803 with a clear victory for the workers. Woollen workers were in general concerned to act within legal channels, and violence ensued only after other methods of industrial pressure and negotiation had failed. ${ }^{112}$

In the textile towns of Leiden, Sedan, and those in the Aachen-Verviers region as well, industrial relations were more regulated and institutionalized than the phrase 'negotiating by riot' would suggest. The frequent and well-organized strikes, although expressions of a 'great anger', were more

111 Hobsbawm, 'The Machine Breakers', repr. in Labouring Men, 7.

112 Randall, Before the Luddites, 147; idem, 'The Shearmen', 284, 292. For a detailed account: Hammond and Hammond, The Skilled Labourer, 167-19o. 
important as instruments of collective bargaining than uncontrolled rioting. There are also many indications of workers trying to establish permanent combinations and representations, by which they were able to negotiate with the employers, to conclude collective agreements, and to petition and communicate with the authorities about the regulation of labour regimes in different industrial centres.

In spite of the migratory movements of the shearers and the transnational transfer of their action repertoires, they did not form transnational combinations transcending the territorial fragmentation in the area between the Meuse and the Rhine. Invitations to the Eupen shearers by the Verviers Confraternité des tondeurs in 1759 and by the Monschau strikers in 1797 to join were declined. The main reason is that the employers and the authorities, addressed by the shearers to regulate their labour, used the territorial divisions to their advantage, both in the competition with cloth merchants in adjacent centres, and in their struggle with the workers. ${ }^{113}$ The authorities were not prepared or able to issue transnational labour regulations, and the shearers were not able to enforce these. Their internationalism was one of 'insolence', not of 'association'. We have to wait until 1864 for such an international association to be formed: the International Workingmen's Association, also known as the First International.

\section{Appendix 1.1 Regulations against shearers' collective actions}

In Sedan, the Conseil du Commerce ordained in August 1720:

il [est] fait deffense à tous compagnons tondeurs, et autres ouvriers de convoquer ni tenir aucunes assemblées [...], d'exiger aucun tribut sous le nom de 'fricasses' et de crier 'cloex' pour faire cesser le travail, ni déclarer sales aucunes boutiques en général, ni les compagnons en particulier. ${ }^{114}$

In Eupen, an Ordonnantie weghens de Droogscherersgasten, 16 February 1724, prescribed:

es ist allen Scherern und Meisterknechten auf das strengste verboten sich offen oder heimlich in Eupen oder außerhalb zu versammeln oder zusammenzurotten, oder Verbindung mit anderen Schererwinkeln aufzunehemen, [...] einen Winkel faul zu machen, noch jemand eine 
Strafe aufzuerlegen der im Falle eines Streiks auf einem odern andern Winkel gearbeitet hat. ${ }^{115}$

In Monschau, the charter of the society of fine cloth merchants (Feine Gewandschaft), issued 30 March 1742, stated:

sollen keine Knechte hieselbst auf einem eintzigen winckel sich unterstehen [...] knechte und winkels, mit dem lesterworte fauhl oder winckelfauhl auszuwerffen oder auff eine einzige art und weise, solche mit dem Sauffpott und neuen erlernen des handtwercks zu vexiren, zu beschweren und abzustraffen gesinnen, sondern es sollen hieselbst freie und reine winckel seyn, wo alle frey zugelassen werden. ${ }^{116}$

For Hodimont, in a decree by the Brussels authorities, 18 October 1743,

Qu'il est rigoureusement défendu aux garçons et maîtres tondeurs de décrier aucune boutique ou de déclarer aucune sale ou pourrie (comme ils disent), comme aussi de s'attrouper ou s'assembler soit en public, soit en cachette, dans Hodimont ou ailleurs, pour former aucun complot, à peine d'être tenus pour séditieux. ${ }^{117}$

In Aachen, Bürgemeistere, Scheffen und Rath (the mayor, aldermen, and council) prohibited by resolution of 7 October 1746

unzulässige Zusamenkombsten [zu] halten, [...] sich Vorsteher unter ihnen zu erwehlen, ihrem Beliebten nach Schlüsse und Satzungen zu machen, denen Meisteren [...] die Arbeit zu verbieten, deren Winckelen zu schliessen und ihre Mitgasten zu dem Ende unter angemasster Bestraffung von etlichen Tonnen Bier auffutreiben, auch eine eygene Cassam auffzurichten. ${ }^{118}$

In Vaals, on the observation in 1765 by the Hoofdbank Holset-Vaals-Vijlen that

Mißbräuche und Unerlaubtheiten unter die Lakenbereijders of Droogscheerdersgasten eingeschlichen sind, weil einige eigenmächtig ohne

115 Hermanns, 'Die Tuchscherer', 156; see also Henkel, 'Taglohn, Tradition und Revolution', 50-53.

116 Henkel and Taubert, Maschinenstürmer, 88; Barkhausen, Die Tuchindustrie, 81-82.

117 Gayot, 'Les “ouvriers les plus nécessaires”', 225; Dechesne, L'avènement du régime syndical, 53. This is the same decree as the one for Eupen in 1724 (ibid., 55).

118 Beiträge und Material, 87. See also Kisch, 'Das Erbe des Mittelalters', 305; Ebeling and Schmidt, 'Zünftige Handwerkswirtschaft', 331. 
Grund ihre Winkels verlassen um andere Gäste oder Knechte, die ruhig in ihren Geschäften arbeiten, Furcht anzujagen oder verbieten, mit ihrem Geschäft fortzufahren, zu manchen Zusammenkünften sich aneinanderschließen, einige Personen oder ganze Geschäfte für schmutzig und ungeschickt erklären,

it was ruled that there should come an end to

dem sogenannten Schimpfen, dem Verlassen und Abspringen von der Arbeit, allen Zusammenschwörungen und Beschmutzen und im allgemeinen allen aufständigen Unternehmungen. ${ }^{119}$

And a decree by das Burtscheider Gericht, April 1767, stated:

den Tuchmachern und Scherern [wird] alle Versammlungen, das Aufstellen von Statuten, das schelten, schmähen, auf- und umtreiben vor den Werkstätten, sogenanntes faulmachen und verwerfen, und alle Eigenmächtigkeit verboten. ${ }^{120}$ 


\title{
2 Transnational cigar-makers
}

\author{
Cross-border labour markets, strikes, and solidarity at the \\ time of the First International (1864-1873)*
}

\begin{abstract}
Several authors have argued that one of the main goals of the International Working Men's Association was to control transnational labour markets. In the eyes of trade unionists, especially in Britain, uncontrolled crossborder migratory movements threatened to undermine wage standards and working conditions. Their solution was to organize internationally, both to prevent strike breaking and wage cutting by workers from abroad, and to support unions elsewhere to raise wage standards in their home countries. Cigar-makers operated in a cross-border labour market and were very prominent in the First International. In this chapter I describe the connections between German, British, Dutch, Belgian, and American cigar-makers as migratory workers, and their actions to stimulate, support, and coordinate trade unions internationally. I argue that the international cooperation of cigar-makers was primarily motivated by a wish to regulate their cross-border labour market, not so much by an abstract ideal of international solidarity.
\end{abstract}

Keywords: International Working Men's Association, First International, cigar-makers, transnational labour markets, international solidarity

* Reprinted from Ad Knotter, 'Transnational Cigar-Makers: Cross-Border Labour Markets, Strikes, and Solidarity at the Time of the First International (1864-1873)', International Review of Social History 59(3) (2014), 409-422. I thank the Société d'études jaurèsiennes, particularly its secretary Marion Fontaine, for inviting me to write this paper for their conference '1914, l'Internationale et les internationalismes face à la guerre' (Paris, 24-25 March 2014), where it was first presented. I profited from some suggestions by the French expert in this field, Michel Cordillot.

Knotter, Ad, Transformations of Trade Unionism: Comparative and Transnational Perspectives on Workers Organizing in Europe and the United States, Eighteenth to Twenty-First Centuries. Amsterdam, Amsterdam University Press, 2018 DOI: $10.5117 / 9789463724715 \_$CHO2 
In one of his many pleas for a transnational labour history, Marcel van der Linden argued that the International Working Men's Association, later to be known as the First International, should not be considered a form of cooperation of representatives of different nations. ${ }^{1}$ According to Van der Linden, this view reflected a later stage of internationalism, which emerged in the 1890 s and which he called 'national internationalism'. This kind of internationalism developed in the period of the national integration of European working classes between 1871 and 1914. In his view, the internationalism at the time of the First International would better be analysed as 'sub-national'. Because national trade unions and other working-class organizations hardly existed, it organized international solidarity between local organizations in different countries. ${ }^{2}$

In this chapter, I want to elaborate on this argument by emphasizing that the kind of 'sub-national' internationalism described by Van der Linden reflected a transnational, cross-border organization of the labour market, preceding the national integration of working classes and labour markets. This relationship was observed already in the 1960 s by the eminent Belgian historian of the First International, Jan Dhondt:

One knows very well how much the workers in this period had a travelling existence. Hungarian labourers were not rare in London; Belgian labourers counted for tens of thousands in France, and, concerning the German labourers, they could be met in almost every country. The International of revolutionary radicals was thus doubled by an International of the workers themselves, stretching across the world, far from their country of origin. ${ }^{3}$

Cigar-makers, whose migratory behaviour and early involvement in radical politics are well known, both operated on a transnational cross-border labour market and were very prominent in the First International. They are, in fact, a perfect illustration of the relationship between the existence of a transnational labour market and workers' internationalism. As far as the cigar-makers' history, including their relationship with the First International, has been written, however, it has been done predominantly in a national context (cf. the literature in the notes). In this chapter I want

1 Van der Linden, 'Transnationale Arbeitergeschichte', 267; see also idem, Workers of the World, 5 .

2 Idem, 'The National Integration of European Working Classes'; repr. in idem, Transnational Labour History; idem, Workers of the World, 268-270 and 272.

3 Jan Dhondt, 'Rapport de synthèse', 469. 
to show that the history of this relationship can best be written from a transnational or 'entangled' cross-border perspective. ${ }^{4}$ If we follow Van der Linden, the international character and aim of the First International cannot primarily be understood in its current meaning, referring to relationships between nation-states or national institutions, but in the sense of what today is called transnational, connecting people in cross-border social networks. 'Transnational' has a much broader meaning than 'international', as it refers to the interaction between individuals, groups, and organizations across national borders, and to structures that extend beyond the nation-state.

In recent years the concept of histoire croisée has gained some popularity in transnational history, mainly in the context of the study of the crossnational transfer of ideas and cultural practices. ${ }^{5}$ As far as this kind of 'entangled history' tries to overcome enclosed national approaches and opens our minds to the transnational exchange of ideas and inter-connectedness of social events, it can be helpful to orient transnational studies, but in this case I want to go beyond the transfer of ideas, and look for the cross-border social relations behind this transfer, i.e., the transnational labour market for cigar-makers, which shaped their world-view, and also their actions to cooperate internationally.

Already long before the 'transnational turn' entered the debate, several authors have argued that the main goal of the International Working Men's Association was to control transnational labour markets by organizing cross-border solidarity. Daisy Devreese, a student of Dhondt, wrote: '[T] he [International Working Men's Association] was of value as an instrument in daily life because it aimed at acting as a regulator, on an international scale, of the supply of labour. ${ }^{6}$ The International considered itself particularly useful in the case of strikes, as stated at the Geneva Congress of 1866: 'To counteract the intrigues of capitalists always ready, in cases of strikes and lock-outs, to misuse the foreign workman as a tool against the native workman, is one of the particular functions which our Society has hitherto performed with success.' 7

Precisely this issue had been brought up by the English trade unionists who took the initiative to establish an 'International'. In their address 'To

4 The literature on the so-called transnational turn in the writing of history is abundant. See, for instance, in the field of labour history, Fink (ed.), Workers across the Americas.

5 The classical text is Werner and Zimmermann, 'Histoire croisée'; or the English version 'Beyond Comparison'.

6 Devreese, 'An Inquiry into the Causes and Nature of Organization', 285; see also idem, 'L'Association Internationale des Travailleurs', 20-21.

7 Cited ibid., 20, and Devreese 'An Inquiry into the Causes and Nature of Organization', 285. 
the Workmen of France from the Working Men of England' (December 1863) they had argued:

A fraternity of peoples is highly necessary for the cause of labour, for we find that whenever we attempt to better our social condition by reducing the hours of toil, or by raising the price of labour, our employers threaten us with bringing over Frenchmen, Germans, Belgians, and others to do our work at a reduced rate of wages. ${ }^{8}$

This was of particular concern to the British trade unionists whose relatively high wages were threatened by less well-off immigrants from other European countries. In the 1850 s and early 1860 os, strike breakers were increasingly recruited by employers from abroad, as, for example, in strikes of gas stokers, bakers, cigar-makers, tailors, and pianoforte-makers in London. During the great London builders' strike in 1861, the employers threatened to import foreign workers en masse. The union had tried to prevent this by writing to working men's associations abroad, but to no avail. ${ }^{9}$ For the London Trades Council, formed in that same year, this failure to prevent the import of strike breakers was the main reason for seeking contact with representatives of the French workers, which led to the establishment of the International in 1864. This explains the content of their address, cited above. ${ }^{10}$

Two years later, in 1866, during a major tailors' strike in London, it became clear how effective the International could be in organizing international solidarity. It helped to prevent the recruitment of strike breakers in Belgium, France, Switzerland, and Germany (Hamburg and Berlin), and the Paris tailors sent financial help. As a result, the masters quickly gave in. 'Nothing had struck greater consternation into the camp of the employers than the fact that they could not obtain men from the Continent by the prompt action taken by the association', concluded the London tailors' union. ${ }^{11}$ A tailors' strike in Edinburgh in that same year was reason to issue another warning to

8 Cited by Van der Linden, 'The Rise and Fall of the First International', 331; repr. in Van der Linden, Transnational Labour History; see also idem, 'Pourquoi le déclin de la Première Internationale était-il inéluctable?', 128.

9 Prothero, Radical Artisans, 116; on the importance of the London builders' strike, see also Collins, 'The International and the British Labour Movement', 24-27.

10 Cf. Knudsen, 'The Strike History', 307. The address was written by George Odger, Secretary of the London Trades Council, later to become the first (and only) president of the International. Looking back (in The Times, 29 June 1871) after his resignation as a member, he declared that the International had been formed to promote 'peace and the raising of continental wages to British levels' (my italics); cited by Collins and Abramsky, Karl Marx and the British Labour Movement, 214. 11 Cited by Eisenberg, Deutsche und englische Gewerkschaften, 172. 
the German tailors, ${ }^{12}$ which also reached Denmark. The Danish Folkebladet informed its readers of the strikes in Britain and issued a warning that British employers were trying to find workers in Copenhagen, Stockholm, and Kristiana (now Oslo), because they were prevented from doing so by effective labour organizations (i.e., the International) in France, Belgium, Germany, and Switzerland. ${ }^{13}$

In 1867 it was the Paris tailors' turn to strike, and the London tailors' to refuse any work being done in London for Paris firms. ${ }^{14} \mathrm{~A}$ Paris victory was followed by a new London tailors' strike, and they now received help from tailors in Paris and other French cities, while the International raised funds on the continent and in the United States. ${ }^{15}$ At the request of the International, for instance, money was sent by Berlin tailors, cigar-makers, and carpenters. ${ }^{16}$

The successes of the International in the tailors' struggles played a decisive role in advancing its popularity and prestige in the trade union movement, both in Britain and internationally. ${ }^{17}$ The British and French examples were followed by tailors in Brussels, who in April 1867 also staged a strike and joined the International in June of that same year. ${ }^{18}$ They made a huge impression in Germany too. In October 1867 an Allgemeine Deutsche Schneiderverein was formed under the influence of German members of the International, more specifically its Cologne and Berlin sections, which were in close contact with leading internationalists in London. ${ }^{19}$ At that time there were many German tailors in London, some of whom were members of the General Council, such as Johann Georg Eccarius (then a close friend of Karl Marx), Albert F. Haufe, and Friedrich Leßner. They held meetings for

12 'Warnung des Korrespondierenden Sekretärs des Generalrats für Deutschland Karl Marx an die deutschen Schneidergesellen 4. Mai 1866', repr. in Institut für Marxismus-Leninismus beim ZK der SED, Die Internationale in Deutschland, 117-118, and 720, n. 118.

13 Lahme, 'Zur Vorgeschichte der dänischen IAA-Sektion', 56-57; the original text in Danish is on p. 7o. On the attempts to recruit strike breakers in Denmark, see also Collins and Abramsky, Karl Marx and the British Labour Movement, 72; on the international tailors' strike wave in general, see ibid., 83-84.

14 See also Cordillot, 'La section Française de l'Internationale, 45-46.

15 Knudsen, 'The Strike History', 310-311; Prothero, Radical Artisans, 116-117.

16 Engelberg and Dlubek, 'Le mouvement ouvrier allemand', 182; see also Engelhardt, 'Nur vereinigt sind wir stark', 346, n. 59 .

17 'The 1866 tailors' strike established the International as a force in the labour movement': Collins and Abramsky, Karl Marx and the British Labour Movement, 288.

18 Devreese, 'Ambachten, arbeidsmarkt en arbeidersbeweging', 133-134.

19 Cf. Engelhardt, 'Nurvereinigt sind wir stark', 353-356. The German tailors were also inspired by the example set by the cigar-makers, who had established a national union two years earlier (1865): ibid., 356-359. 
the German-speaking tailors in London in support of the strike and tried to organize solidarity on the continent. ${ }^{20}$

Because of its ability to mobilize international support, the International was very effective for the British trade union movement, as it reported in 1867:

It used to be a standard threat with British capitalists, not only in London, but also in the provinces, when their workmen would not tamely submit to their arbitrary dictation, that they would supplant them by an importation of foreigners. The possibility of such importations taking place was in most cases sufficient to deter the British workmen from insisting on their demands [...]. The action taken by the Council had had the effect of putting a stop to these threats. ${ }^{21}$

In an overview of the actions of the International in Britain, historian Henry Collins even concluded that:

the public significance of the International to the British labour movement was [...] limited to its function as an international trade union liaison committee whose assistance could be secured during strikes by unions which affiliated and even - as in the case of the Engineers during the Nine-Hour movement of 1871 - by those which did not. ${ }^{22}$

The International assisted not just British workers, however. It organized support for workers on strike everywhere, by calling on fellow workers in other countries to prevent the employment of strike breakers and by helping to provide money for the strikers. ${ }^{23}$ It was, for instance, very active in supporting strikes in France, both in Paris and in the provinces. ${ }^{24}$ The importance of the international strike wave in the 1860 s and early $1870 \mathrm{~s}$ for the implantation and development of the International can hardly be overstated. It had the effect that the ideas of Karl Marx on the economic

20 Eisenberg, Deutsche und englische Gewerkschaften, 170-176. The president of the tailors' union, Heinrich Schob, joined the International in 1867: Engelberg and Dlubek, 'Le mouvement ouvrier allemand', 182 .

21 Cited by Knudsen, 'The Strike History', 310.

22 Collins, 'The International and the British Labour Movement', 38 and 27: '[T]he most important single motive impelling trade unions to affiliate was the desire to prevent strike-breaking through the introduction of European labour.'

23 Cf. Devreese, 'An Inquiry into the Causes and Nature of Organization', 286 (n. 14 lists strikes supported by the International).

24 Several examples appear in Archer, The First International in France, 414. 
struggle as a crucial element in the development of the labour movement won the day, against the (at that time still influential) opinions of Proudhon in France and Lassalle in Germany that strikes made no sense. ${ }^{25}$

The role of the General Council in mobilizing international support in trade disputes was part of the argument of the 'Marxist' Friedrich A. Sorge in support of a centralized organization at the Hague Congress of the International in 1872. Against the assertion of the 'Bakunist' James Guillaume that the General Council was of no use in strikes, he pointed to the strike of the bronze workers in Paris in 1867, which had achieved victory thanks to financial aid organized by the General Council, to the strike of the Newcastle engineers in 1871, which the General Council had helped to succeed by preventing foreign, especially Belgian, engineers being recruited as strike breakers, and to the strike of the New York Singer sewing-machine workers in 1872, demanding an eight-hour working day, who had appealed to the General Council to help forestall the importation of European workers. ${ }^{26}$

In the same vein he could have mentioned the Antwerp cigar-makers' strike of 1871. During the meeting of the General Council on 13 June 1871, James Cohn, delegate of the London Cigar-Makers' Mutual Association, reported on the action in support of the Belgian cigar-makers who had been locked out by their employers. The report deserves to be cited at length, because it testifies the international character of the cigar-makers' labour market and struggle:

Citizen Cohn then gave in a report of the Cigar makers' Lockout in Belgium. The London Cigar makers had sent over some delegates, who

25 On the French case: Knudsen, 'The Strike History', 313-314; Cordillot, 'La section française de l'Internationale', 50-54. The ideas of Karl Marx on the importance of wage struggles were expounded in a paper read before the General Council in May and June 1865, published in 1898 as Value, Price and Profit, and became the foundation of a resolution on trade unions and strikes at the Geneva Congress in 1866: Collins and Abramsky, Karl Marx and the British Labour Movement, 104-105 and 116-118.

26 Institute of Marxism-Leninism of the CC, CPSU, Documents of the First International: The Hague Congress of the First International September 2-7, 1872. Minutes and Documents, 67 and 696; idem, Reports and Letters, 85 and 230. On the role of the International in the 1867 Paris bronze workers' strike, see Archer, The First International in France, 82-83, and Cordillot, 'La section française de l'Internationale', 37-43; on its role in the 1871 Newcastle engineers' strike: Allen, et al., The North-East Engineers' Strikes, 135 and 148; and Karl Marx Friedrich Engels Gesamtausgabe (hereafter, MEGA), I. Abteilung: Werke, Artikel, Entwürfe, Bd. 22, März bis November 1871 (Berlin, 1978), Text, 589-591 (Meeting of the General Council 8 August 1871), and 596 (Meeting 22 August 1871). The Singer sewing-machine workers' strike was part of a massive strike movement in New York in 1872, which was lost. The loss hastened the disintegration of the already divided International in New York: Montgomery, Beyond Equality, 328-335. 
stayed there fifteen days, and thoroughly investigated the state of affairs. The masters had obtained 30 men of Holland, but everyone had been sent back again. They had also obtained 25 girls from Metz and Strasbourg, but sixteen of them had also left, so that after seven weeks, the masters had only obtained nine hands. Not one of the men locked out had offered to go in, and the masters were as near as beaten as could be. [...] The Cigar makers of Hamburg had warmly espoused the cause and found work for 30 of the men locked out. The following sums had already been sent to Belgium from England [there follows an account of donations by several trade unions, among others by the London Cigar Makers, Dutch Cigar Makers, and Belgian Cigar Makers in London]. ${ }^{27}$

\section{Political cigar-makers}

The movement found its strongest support among the cigar-makers, who over the course of many years formed the driving force and the leadership of the social democratic party in my home town..$^{28}$

One cannot sustain that all social democrats are cigar-makers, but the claim that all cigar-makers are social democrats is almost true. ${ }^{29}$

Writing about 'political shoemakers', Eric Hobsbawm and Joan Scott related the proverbial radicalism of shoemakers, apart from their independence and poverty, to 'the semi-routinized nature of much of their work, which could readily be combined with thinking, watching and conversation'. As Hobsbawm and Scott remarked, shoemakers shared this characteristic with other crafts, like tailoring and cigar-making, which were also well represented in radical movements in the nineteenth century. Also, the working environment was relatively quiet. Like shoemakers, cigar-makers were known to appoint a 'reader': one of the men reading newspapers or

27 MEGA, I. Abt., Bd. 22, Text, 563 . Cohn was born in Kiel (then in Denmark) in 1829 as Jesaias Michael Cohn. He had probably moved to England in 1846, lived in Bristol and Liverpool, and after 1853 in London. He died in London in 1884 . Information kindly provided by Jan Ingemann Sørensen (Copenhagen, 16 August 2016). See also Sørensen, 'De Danske socialister og Første Internationale', 41-43.

28 Bruhns, 'Es klingt im Sturm ein altes Lied!', 12, cited by Möller, 'Zigarrenheimarbeiter in Altona-Ottensen', 86-87.

29 Der arme Teufel [Detroit] 11 September 1886, cited by Rößler, “Amerika, du hast es besser”', 88. 
Figure 2.1 Julius Bruhns (Hamburg 1860-Offenbach 1927). Like several other German cigar-makers, Bruhns became a prominent social democrat. In 1921 he wrote his memoirs Es klingt im Sturm ein altes Lied (http:// library.fes.de/pdf-files/netzquelle/a-58090.pdf)

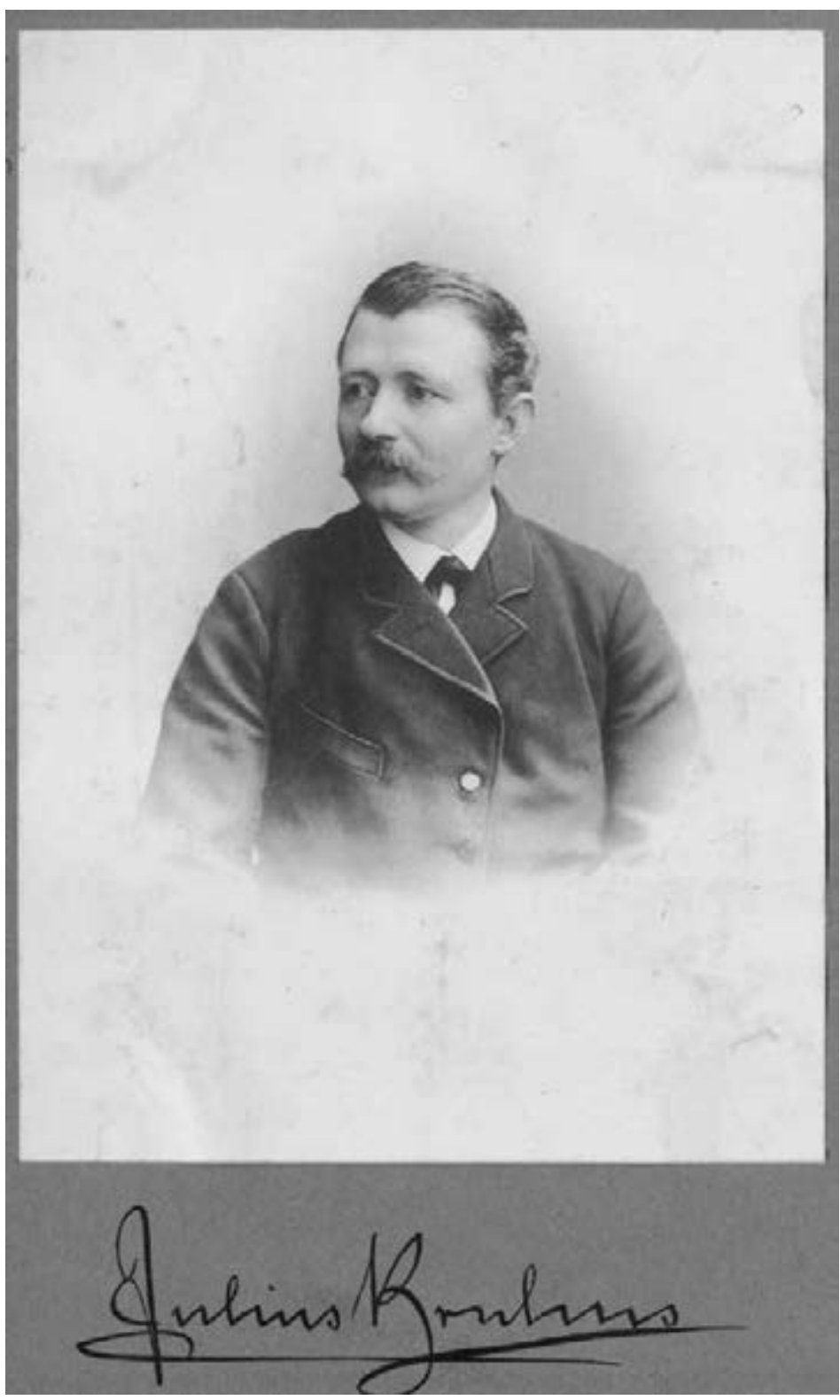

Collection iish 
books out loud. ${ }^{30}$ According to an American observer 'cigar-makers perceived themselves as a "race of philosophers", and loved to debate politics, the labor movement, current events, and life generally'. ${ }^{31}$ Likewise, in Cuba: 'The cigar maker [...] loves discussions and this can be explained in terms of the way he works and his wide knowledge. There are daily debates in and out of work and there are times when they gain such impetus that the whole gallery takes part.'32 The German socialist cigar-maker Julius Bruhns (1860-1927) wrote in his memoirs: 'The whole day there were political debates [...] and the foundations for the abilities of many competent social democratic leaders had been laid during these vehement discussions about socialist goals and theories with colleagues in cigar-makers' workshops. 33

Samuel Gompers, later to become one of the United States' most influential trade union leaders, started working in a New York cigar factory in the 1860 s and remembered political discussions, singing, and reading by one of the workers, who would be paid by his colleagues to read aloud while the others worked. In fact, Gompers acted as a reader himself.. ${ }^{34}$ The custom of employing a reader in cigar factories had originated in 1865 in Cuba - where cigar-making and the reading habit were associated with political radicalism as well - and had spread from there to Spanish-speaking workshops in the United States, ${ }^{35}$ but it was also well known in cigar factories in Germany. Perhaps it was imported there from Cuba by sailors arriving in the German port cities of Bremen and Hamburg, but this is hard to prove. In the 186os 'reading', especially of political writings, became widespread in German

30 Hobsbawm and Scott, 'Political Shoemakers', 28. The idea that shoemakers, tailors, and cigar-makers in particular had a philosophical approach because of their quiet working conditions can already be found in Uhen, Gruppenbewußtsein und informelle Gruppenbildung, 49. On the appointment of a reader by German tailors (without further reference), see Eisenberg, Deutsche und englische Gewerkschaften, 171. The appointment of a reader occurred not just in artisan trades; on the reading of 'an English Chartist newspaper undertaken by one of their comrades who is paid by them to do this' in a British linen factory in Landerneau (Brittany, France) in 1849, see Bensimon, 'British Workers in France', 177.

31 A.M. Simons, 'A Label and Lives - The Story of the Cigar Makers', Pearson's Magazine, January 1917, 70, cited by Cooper, Once a Cigar Maker, 66.

32 García Galló, El tabaquero cubana, cited and translated by Stubbs, Tobacco on the Periphery, 88.

33 Bruhns, 'Es klingt im Sturm ein altes Lied!', 13-14, cited by Möller, 'Zigarrenheimarbeiter in Altona-Ottensen', 86-87.

34 Gompers, Seventy Years of Life and Labor, I, 34-35,44 and 68-69, cited by Schneider, Trade Unions and Community, 56.

35 Cooper, Once a Cigar Maker, 17 and 66; on 'readers' in the Americas, see Tinajero, El Lector; Daniel, 'Rolling for the Revolution'; Maatta, 'El Lector's Canon'. On the origin of readers in Cuban workshops, see also Stubbs, Tobacco on the Periphery, 98-99, and Casanovas, Bread, or Bullets!, 83-91 and 112-113. 
Figure 2.2 Interior of a cigar factory in Havana, Cuba, c. 1903. This postcard shows a lector reading a newspaper to entertain his co-workers. The habit of 'reading' originated in Cuba around 1865 and became widespread in Germany as well.

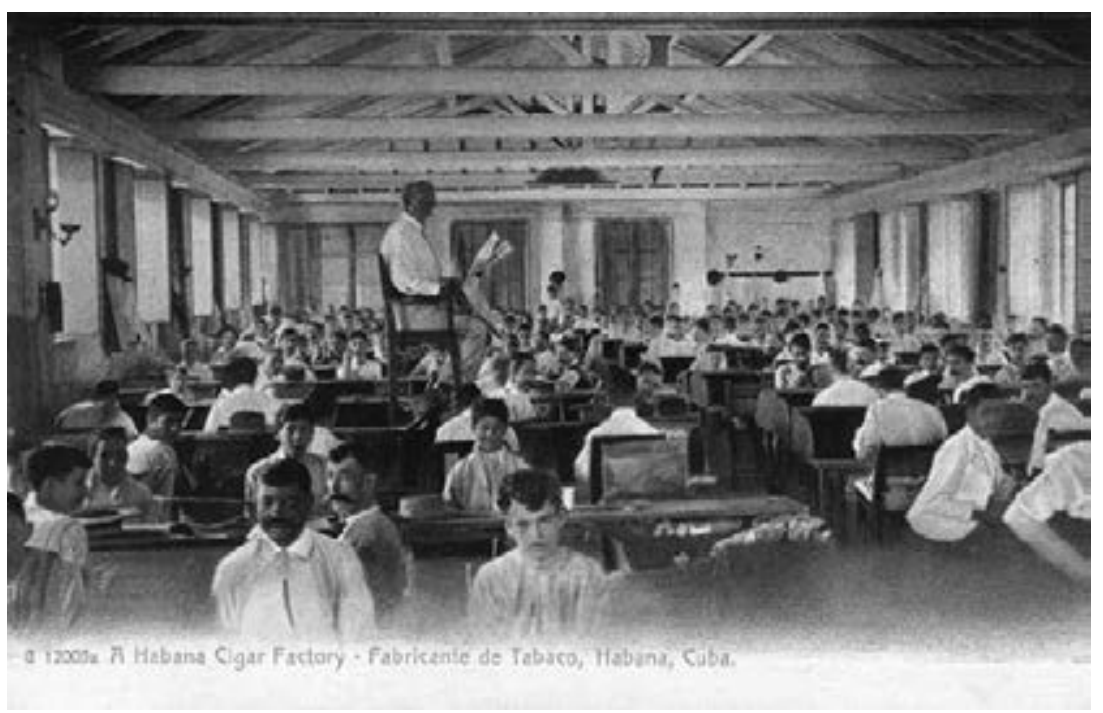

Mary Evans Picture Library. Used with Permission

cigar-makers' workshops and was sometimes deliberately used by socialist agitators. ${ }^{36}$ German immigrants being very prominent in New York cigarmaking, ${ }^{37}$ Samuel Gompers's experiences with 'reading' were most likely related to this German tradition.

Although the idea of a straightforward relationship between working conditions, intellectual attitudes, and early trade unionism in the cases of tailors, shoemakers, and cigar-makers has been subject of debate, ${ }^{38}$ the important role of cigar-makers in the German socialist movement has since long been recognized by German labour historians. ${ }^{39}$ Their prominence

36 Möller, 'Zigarrenheimarbeiter in Altona-Ottensen', 84-9o; a glimpse of this practice is revealed in October 1872 when 28 cigar-makers in a Berlin factory went on strike 'because the reading of the Neue Social-Demokrat, which until then had been tolerated, had suddenly been forbidden by the foreman': Machtan, Streiks und Aussperrungen, 258.

37 Schneider, Trade Unions and Community, 55. Cuban cigar-makers in New York were also active in the International: Casanovas, Bread, or Bullets!, 113.

38 Cf. Engelhardt, 'Nur vereinigt sind wir stark', 370-371.

39 Zwahr, Zur Konstituierung des Proletariats als Klasse; Schröder, 'Arbeit und Organisationsverhalten der Zigarrenarbeiter', 208-210 (orig. in idem, Arbeitergeschichte und Arbeiterbewegung); 
can be illustrated by the fact that with a total number of 123 they were the largest single occupational group among the socialists expelled from Germany in the period of the anti-socialist laws (1878-1890), which is 15.5 per cent; the second-largest group were 90 carpenters (11.5 per cent). It is noteworthy that 104 of these 123 cigar-makers came from Hamburg (and the bordering towns of Altona and Ottensen); the others came from Berlin and Leipzig. ${ }^{40}$ In Leipzig, Hartmut Zwahr found out that cigar-makers were a majority (12) among a group of workers (21) arrested during the May 1848 revolt in Saxony. ${ }^{41}$

One of them was Friedrich Wilhelm Fritzsche (1825-1905), who in 1865 became founder and president of the German cigar-makers' union, the oldest national trade union in Germany. Although a follower of Lassalle, in ${ }_{1867}$ he adhered to the Berlin section of the International Working Men's Association, and established connections with the German-language section led by Johann Philipp Becker in Geneva. In 1869 he was co-founder of the Eisenacher Sozialdemokratische Arbeiterpartei (led by Wilhelm Liebknecht and August Bebel), but he left that party again in $1872 .{ }^{42}$ A contemporary wrote about Fritzsche in his memoirs: 'The Leipzig cigar-worker Fritzsche distinguished himself by his tall stature, his somewhat pressed nose, and an impressive democrats' beard [Demokratenbart] [...]. I can still see the impressive figure of this old Dresden barricade fighter, with his long grey hair, and can still hear his rousing voice.' Through his 'not yet out-of-date suave tone of speaking', he had 'considerable influence among working people'. 43

Cigar-makers were very prominent in the local branches of the First International in cities such as Amsterdam, Antwerp, London, and New York. The last case can be exemplified by the life story of Samuel Gompers.

Burgdorf, Blauer Dunst und rote Fahnen, 182-184; Möller, 'Zigarrenheimarbeiter in AltonaOttensen'. See also Welskopp, Das Banner der Brüderlichkeit, 93 and 266. On the impact of political German cigar-makers in the United States, see Schneider, Trade Unions and Community. 40 See Thümmler, Sozialistengesetz $\$ 28,73-74$ and 153-159; see also Möller, 'Zigarrenheimarbeiter in Altona-Ottensen', 94; Rößler, “'Amerika, du hast es besser”', 99. On the overrepresentation of cigar-makers among socialist candidates and members of the German Reichstag, see Schröder, 'Arbeit und Organisationsverhalten der Zigarrenarbeiter', 248.

41 Zwahr, Zur Konstituierung des Proletariats, 282-283 and 291; there were 300 cigar-makers among the refugees who were expelled from Germany after the 1848 revolution: Schröder, 'Arbeit und Organisationsverhalten der Zigarrenarbeiter', 248, n. 123.

42 Buschak, 'Einleitung'. Cf. the detailed account on Fritzsche in Engelberg, 'Nur vereinigt sind wir stark', 269-271, n. 19; on his contacts with the International: ibid., 300, n. 178; on his relationship with Liebknecht and Bebel: ibid., 416 and 596, n. 7; see also Zwahr, Zur Konstituierung des Proletariats, 165,314 , and 318.

43 Cited by Welskopp, Der Banner der Brüderlichkeit, 410. 
Figure 2.3 Friedrich Wilhelm Fritsche (Leipzig 1825-Philadelphia 1905). After an adventurous life, Fritsche settled in Leipzig as a cigar-maker. He was the founder of the German national cigar-makers' union in 1865 and participated in attempts to establish an international union in the early 1870 s. In the 1880 os he moved to the usA.

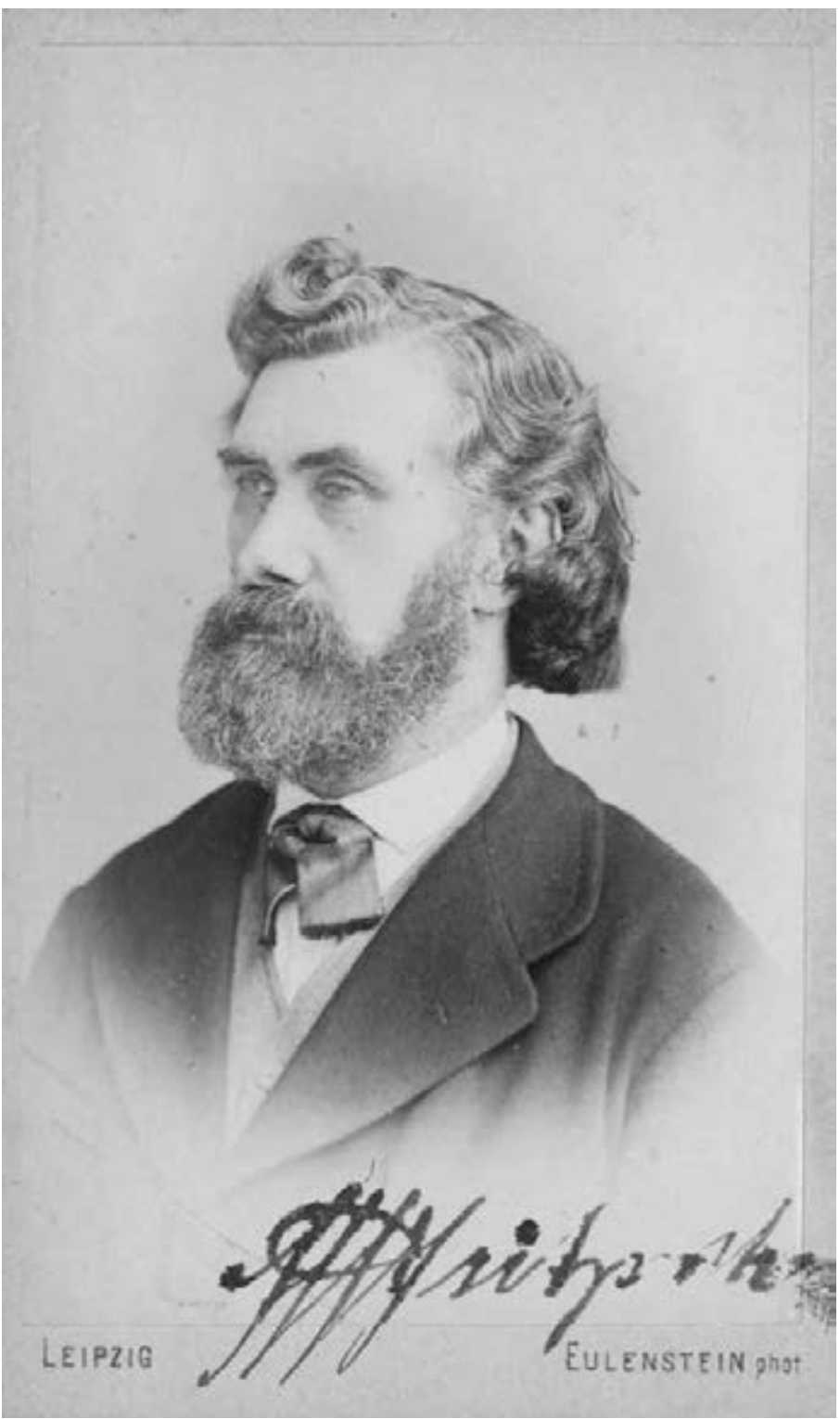

Photograph: Eulenstein, 1869. Collection iish 
As a long-time president of the American Federation of Labor (1886-1924) he stood for an apolitical and anti-socialist kind of business unionism, but in his early years he had been connected to the New York branch of the First International, and had cooperated closely with one of its leading figures, Adolph Strasser, a German-Hungarian immigrant and co-organizer of the Journeymen Cigar Makers' International Union (CMIU) in New York. ${ }^{44}$ In 1873, three of the six members of the North American Federal Council of the International in New York were cigar workers (the Germans Karl Bertrand and Fred Bolte, and the Swede Ferdinand Laurel). ${ }^{45}$

\section{Travelling}

Cigar-makers were a travelling lot, both nationally and internationally. 'The cigar-maker is a wanderer', wrote an American observer. ${ }^{46}$ Geographic mobility created a sense of solidarity, independence, and community among cigar-makers, and was utilized to maintain workplace control. In Patricia Cooper's words: 'Cigar makers regarded their travelling as an assertion of their independence [and] their freedom to control their own time. ${ }^{47}$

In Europe, wandering was, of course, a well-known custom in other crafts also, but in cigar-making, being a recently established trade, it had not developed from an artisan tradition. ${ }^{48}$ Travelling was a device to regulate the labour market and was therefore supported by trade unions, mainly through the instrument of travelling benefits. They could use it in some measure to regulate the size and distribution of the labour force. Travel benefits put the individual unionist in a position where he was not compelled to take work at any price and undercut wages since he was able to tramp on in search of a better job. ${ }^{49}$ In 1865 the newly established German cigar-makers'

44 Schneider, Trade Unions and Community, 45, 56, 66-67, and 233; see also Perrier, 'De l'Internationale à "syndicalisme pur et simple”'; and Gerth, 'The Retreat from Ideology'. Internationalism, not only among the various nationalities in New York, but also across the Atlantic, was still much alive in 1876 , when Strasser 'called upon his fellow unionists to join hands with the English in their struggle for daily bread', and even aspired 'to unite all the trade and labor unions in both hemispheres into one International Brotherhood': cited in Yearley, Britons in American Labor, 60 .

45 Bernstein, The First International in America, 162; Perrier, 'Idées et movement socialistes aux États-Unis', 303.

46 Simons, 'A Label and Lives', cited by Cooper, Once a Cigar Maker, 75 .

47 Cooper, 'The “Traveling Fraternity"', 127.

48 Cf. Rößler, 'Traveling Workers', 129.

49 Ibid., 133-135; Cooper, Once a Cigar Maker, 88. 
union decided to raise travelling benefits 'to enable the departure of the unemployed, so that they would not cause downward pressure on wages'. $5^{0}$ Before, every local society had had its own travelling fund..$^{1}$

From the 186os onwards German cigar-makers extended their travels and made the trip across the Atlantic in large numbers, where for a while they became the most important ethnic group in the booming cigar-making industry, especially in New York. $5^{2}$ In general, cigar-makers from different countries were highly mobile between the various centres of cigar-making on both sides of the Atlantic. Thomas M. Dolan, a union organizer in Cincinnati and Detroit, 'never forgot the lessons [...] learned in unionism as a Liverpool cigar-maker'.53 The German trade union leader Fritzsche (mentioned above) had started his working life travelling through Germany, Switzerland, France, and Italy. In Switzerland he had cooperated with refugee Johann Philipp Becker, later to become the representative of the First International for the German-speaking countries. ${ }^{44}$ After the forced dissolution of the German cigar-makers' union under the anti-socialist laws, he departed for the USA in 1881 and stayed there after a successful agitation trip. 55

Cigar-makers from Hamburg went to Sweden and Denmark. Hamburg cigar-makers brought Lassallean ideas into the Copenhagen tobacco workers' union Enigheden (Unity), for instance. ${ }^{56}$ Hamburg in its turn attracted cigar-makers from other parts of Germany, Belgium, the Netherlands, and Scandinavia. ${ }^{57}$ Among the seventeen foreign-born socialists expelled from Hamburg because of the anti-socialist laws in $188_{3}$, there were eleven from Denmark, of whom at least eight were cigar-makers. ${ }^{8}$ In the Netherlands, their mobility was noted as well. An 1869 report stated: 'It is said that they are a wandering personnel, roaming around the country, and that they all

50 Cited by Buschak, Von Menschen, die wie Menschen leben wollen, 523 .

51 Frisch, Die Organisationsbestrebungen, 29-30; Bürger, Die Hamburger Gewerkschaften, 12.

$5^{2}$ Rößler, 'Traveling Workers', 145; see also idem, '“Amerika, du hast es besser"'. Schneider, Trade Unions and Community, 55, even describes the 'budding New York cigar industry' as 'an extension of the German cigar industry'.

53 Cited in Yearley, Britons in American Labor, 150.

54 Zwahr, Zur Konstituierung des Proletariats, 253; on John Philipp Becker, see Devreese, “'Ein seltener Mann"'.

55 Schröder, 'Arbeit und Organisationsverhalten der Zigarrenarbeiter', 249; his departure to the United States was related to (false) accusations of fraud with trade union money: Klüss, Die älteste deutsche Gewerkschaft, 50-51. On other socialist cigar-makers departing for America because of the anti-socialist laws (especially from Hamburg): Thümmler, Sozialistengesetz $\S 28$, 147-150, and Rößler, “'Amerika, du hast es besser”', 101ff.

56 Lahme, 'Der Deutsche Social-Demokratische Arbeiterverein', 248-250.

57 Rößler, “'Amerika, du hast es besser”', 89-9o and 96.

$5^{8}$ Thümmler, Sozialistengesetz $\S 28,64$ and 139-145. 
know each other. ${ }^{59}$ Especially among the many Jewish cigar-makers in Amsterdam it was very common to work in London for a longer or shorter period. Many of them lived half-time in London, half-time in Amsterdam. ${ }^{60}$

While migration within Europe was often circular, migration to the United States seems to have been mostly permanent. Again, the life story of Samuel Gompers can serve as an example: his family originated from Amsterdam, where cigar-making was a trade of poor Jews. In the 1840 os the family had moved to London, like many other Jewish cigar-makers from Amsterdam, who had formed a closed Dutch community on the so-called Trenter Grounds along Trenter Street near Spitalfields in London's East End. At that time, cigar-making in London had the reputation of being a Dutch-Jewish trade. ${ }^{61}$ Samuel had been born in London in $185^{\circ}$ and apprenticed to a cigar-maker at a very young age, but in 1863 the family decided to move to New York, where several friends and relatives had already moved. As a member of the London Cigar Makers' Society, Gompers senior could benefit from an allowance from an emigration fund, established by the Society to provide for the passage to the United States. It was part of a larger scheme of cooperation between the English and American cigar-makers' unions to regulate migration. ${ }^{62}$ In the 186os more Jewish cigar-makers of Dutch descent had moved to New York: between 1860 and 1870 their proportion among employed Dutch Jews there had risen from 7 to 25 per cent. ${ }^{63}$ But once in New York, the young Samuel worked with immigrants from Hamburg and Sweden too. ${ }^{64}$

\section{Cross-border connections around the North Sea before the International}

Cigar-making had originated in Cuba and in the eighteenth century had moved to Europe, at first to port cities as an offspring of the overseas trade

59 Cited in Knotter, Economische transformatie, 188.

60 Ibid.

61 Alderman, Modern British Jewry, 9.

62 Yearley, Britons in American Labor, 57: 'American cigar-makers over a period of decades conducted heavy and extremely important correspondence with their brethren in England. Full advantage was taken of these channels of communication to interdict immigration of "unfair men" and to assist skilled men bound for American markets to make their transition with greater ease.' These contacts were established 'long before the Civil War' (ibid., 6o).

63 Swierenga, The Forerunners, 57 and 110-112. On the migration of Jewish cigar-makers from Amsterdam to New York in the 186os, see also Knotter, Economische transformatie, 188 and 335, n. 36 .

64 Rößler, “'Amerika, du hast es besser”', 94. 
in tobacco leaf. Already in 1788 a cigar factory was set up in Hamburg to manufacture leaf imported from Cuba. Several others followed, in both Hamburg and Bremen. In the early nineteenth century, these north German ports became the major European centres for the trade in American tobacco, while Amsterdam acquired a similar position for tobacco from the Dutch East Indies. ${ }^{65}$ When smoking cigars became increasingly popular in Europe, cigar-making developed first in these and other port cities. It increased vastly there in the 1830 s and 1840 s, but expanded into numerous inland provincial centres as well, where labour was cheaper. The skills of the trade were often introduced there by experienced cigar-makers from the older coastal centres of cigar-making. ${ }^{66}$ By about 1860 there were established cigar industries in German towns such as Berlin, Breslau, and Leipzig, to name just a few, and also smaller towns and in rural areas such as Baden, or Dutch inland towns such as Utrecht, 's-Hertogenbosch, and Kampen. ${ }^{67}$

Cigar-making, being a new and expanding trade, was open to entry from outsiders. As there were no formal or informal rules of exclusion, it was easy to access by workers who had trouble entering older, more regulated crafts. For that reason, in cities with a large Jewish population, especially Hamburg and Amsterdam, cigar-making provided opportunities for poor Jews, who entered the trade there on a relatively large scale. ${ }^{68}$ In these cities cigar-making was no Jewish monopoly, however. The growing demand for labour and the lack of formal and informal barriers attracted a heterogeneous workforce. In London the situation was somewhat different. According to Henry Mayhew in his London Labour and the London Poor (first published in 1849/50), Jews acquired a monopoly in cigar-manufacturing there, because it emerged from Jewish street vending:

The cigar street-trade was started [some 20 years ago] by two Jews, brothers [who] supplied the other street sellers. The itinerant cigar-vending was

65 Cf. Stubbs, 'El Habano'.

66 Frisch, Die Organisationsbestrebungen, 12; Schröder, 'Arbeit und Organisationsverhalten', 230; on the Leipzig case: Zwahr, Zur Konstituierung des Proletariats, 93.

67 Ibid., 196; Sluyterman, Ondernemen in sigaren, 17.

68 Schneider, Trade Unions and Community, 51-52; on Jewish cigar-makers in Hamburg, see Frisch, Die Organisationsbestrebungen, 12, and Bürger, Die Hamburger Gewerkschaften, 11: 'Cigar-making in Hamburg developed from an early date. It is very remarkable that in the first half of this century only Jewish workers were employed in this trade; later there was also an influx of Christians.' On Jewish cigar-makers in Amsterdam, see Knotter, Economische transformatie, 188-189, and Hofmeester, Jewish Workers and the Labour Movement, 36 . 
always principally in the hands of Jews. [...] [Also] the manufacture of the cigars sold at the lowest rates is now almost entirely in the hands of the Jews [...].The cigars in question are bought (wholesale) in Petticoat-lane, Rosemary-lane, Ailie-street, Trenter-ground, in Goodman's-field, and similar localities. ${ }^{69}$

In the 1840 Jewish tobacco manufacturers concentrating on the making of cigars had established factories in the East End. ${ }^{\circ}$ Although Mayhew does not mention it, most of the cigar-makers were Dutch, who had arrived in London in that period. In the 1880 s it was noted in Charles Booth's Life and Labour of the People in London: '[This] section of the tobacco trade [...] is in the hands of foreigners, especially the old-established Dutch Jews of Spitalfields', and elsewhere:

The Dutch are chiefly conglomerated in a comparatively small district in Spitalfields, where they are largely engaged in cigar making. These are mostly Jews, but the colony is a longer established one than that of the Polish Jews, as is shown both by the proportion of males to females, and a comparison of numbers with older census returns.

In spite of being an established community, Dutch cigar-makers still kept arriving from Amsterdam to work in London: 'The trade is largely recruited from abroad by Dutchmen, who arrive with a knowledge of their business. The number of boys in London who are learners is not large. ${ }^{71}$

According to another report in Booth's Life and Labour, by 1835 a CigarMakers' Mutual Association had already been formed, as 'one of the pioneers in organizing labour', which was 'conducted on liberal and enlightened principles'. ${ }^{2}$ As an example of these principles it is mentioned 'that, not only are the foreign workmen in London admitted to membership, but also very substantial pecuniary assistance was rendered by it some years ago to those of their trade who were on strike in Amsterdam'. This almost certainly refers to the great Amsterdam cigar-makers' strike of 1873, which was supported by the London Association (see below). The report also notes that 'frequent communications $[. .$.$] take place between this union and the$

69 Mayhew, London Labour and the London Poor, I, 442. Elsewhere (p. 119), Mayhew writes about Jewish cigar-makers who took to the old clothes business when the cigar trade was slack.

70 Pollins, Economic History of the Jews, 97.

71 Llewellyn Smith, 'Influx of Population', 541 and 545; Duckworth and Hardy, 'Brewers and Tobacco Workers'.

72 Fox, 'Tobacco Workers', 377. 
workers both on the Continent and America, and, in its attempt to introduce an international element, its position among other English societies appears to be almost unique'. At that time (1893), its membership was about 850 ; in 1868 it had been $759 \cdot \cdot^{73}$

We encounter the first signs of these international connections in 1849, this time from Germany. In March 1849 there was a strike of 150 cigar-makers in London: 'Then the Hamburg Cigar-Makers' Association decided that none of its members were allowed to go to London, and the president of the society, Julius Hincke, published a circular with the same message to the German cigar-makers. ${ }^{74}$ A similar situation arose in 1857:

In England there was a strike of cigar-makers, and the employers tried to find workers in several German places. These efforts failed because of the discipline of the society of German cigar-makers, who had decided not to act as strike breakers in these cases, and who were informed by English workers. The English cigar-makers had send messages to the towns of Mannheim, Frankfurt (Main), and Heidelberg. Unanimously a boycott was decided upon and sanctioned by Leipzig, Bremen, and Hamburg. ${ }^{75}$

The English manufacturers apparently met with more success in the Netherlands, at least according to a message which appeared in the London Jewish Chronicle of 15 January 1858. An 'Oppressed Cigar Maker' wrote an account of the strike:

The masters being unable to procure English workmen [...] to submit to the lowering of wages, resort to the practice of travelling to Holland and other parts of the continent, and, exaggerating the state of the cigar trade in England, fill the poor Dutchmen's minds with buoyant hopes of high wages. Arriving in a strange land with their wives and families they too soon discover that not only they have been duped but are as badly off as they were in their own country. ${ }^{6}$

73 Ibid.; Smethurst and Carter (eds), Historical Directory of Trade Unions. Volume 6, 120 (citing Royal Commission on Trades Unions, vol. II, Appendix 1869, 318).

74 Todt and Radandt, Zur Frühgeschichte der deutschen Gewerkschaftsbewegung, 123.

75 Todt, Die gewerkschaftliche Betätigung, 83 .

76 Cited by Alderman, Modern British Jewry, 9; on this strike see also Pollins, Economic History of the Jews, 123-125. 
The naivety of the Dutch did not last long, however. In 1864 the Amsterdam cigar-makers founded a trade union called Door Vriendschap Bloeijende (Flourishing through Friendship], which would later become one of the pillars of the Amsterdam section of the International. For Dutch contemporaries the link with London was clear:

In the society [in Amsterdam] mainly Jews were organized. They, with their tendency to be always on the move, were in close contact with London, where many Dutch Jewish cigar-makers worked. [...] It is therefore not surprising that they came into contact with English organizations, and that they tried to apply here what they had learned abroad. ${ }^{7}$

Like the British, the German cigar-makers were early organizers too. Already in the 1820 s a sick fund for Jewish cigar-makers was founded in Hamburg; ${ }^{78}$ in Bremen such a fund dated from $1824 .{ }^{79}$ A nationwide conference of German cigar-makers in 1848 formed an Assoziation der Tabakarbeiter, a kind of umbrella organization of decentralized local organizations, with an estimated membership of about $1,000 .{ }^{80}$ From $185^{2}$ onward, local cigarmakers' associations were suppressed by the German authorities, but many changed into travelling and/or sick funds. This is how they survived the years of persecution. ${ }^{81}$ Cigar-makers were also involved in secret radical political societies, at least in Bremen and Leipzig. ${ }^{82}$ In 1857, Friedrich Wilhelm Fritzsche, whom we have met before as a participant in the 1848 revolution, had returned to Leipzig and had found employment in a cigar factory there. From $185^{8}$ or 1859 he tried to convince his fellow workers to transform their insurance fund into a trade union. In 1864 he succeeded in establishing a local Zigarrenarbeiterverein in Leipzig, and one year later he became the driving force and president of the Allgemeiner Deutscher Cigarrenarbeiter-Verein (established 1865). ${ }^{83}$ It soon attracted members in some 120 towns in Germany.

77 Cited by Hudig, De vakbeweging in Nederland, 55 .

78 Schröder, 'Arbeit und Organisationsverhalten', 234; see also Liedtke, Jewish Welfare in Hamburg and Manchester, 195.

79 Frisch, Die Organisationsbestrebungen, 9.

80 Ibid., 5-27; Schröder, 'Arbeit und Organisationsverhalten', 231-234.

81 Rößler, 'Traveling Workers', 132; Frisch, Die Organisationsbestrebungen, 29-32.

82 Burgdorf, Blauer Dunst und rote Fahnen, 208-214; Zwahr, Zur Konstituierung des Proletariats, 286-292.

83 Ibid., 290, n. 527, and 297; Frisch, Die Organisationsbestrebungen, 33-35; a detailed account can be found in Engelhardt, 'Nurvereinigt sind wir stark', 269-309. 


\section{The International and cigar-makers' strikes in Germany and Belgium}

In 1868 , for the first time, the Zigarrenarbeiterverein became involved in a strike in Berlin against newly imposed factory rules. The nationwide campaign in support of the strike led to a jump in membership from 7,000 to $10,000 .{ }^{84}$ The strike ended in the establishment of a productive association. This outcome could be justified within the Lassallean world-view, ${ }^{85}$ but the strike launched in 1869 in Leipzig for a wage increase took another turn, away from the Lassallean rejection of strikes. The strike involved some 9oo people. ${ }^{86}$ Fritzsche used the profits of the Berlin cigar-makers' producers' association to support the strike in Leipzig. Financial support was also collected in other German towns, such as Hamburg. ${ }^{87}$ In July 1869 Fritzsche, who, as noted earlier, had become a member of the International in 1867 , appealed to Karl Marx, as the representative of Germany in the General Council of the International, to help provide a loan in support of the strikers in the amount of 3,000 Reichstaler. ${ }^{88}$ The International was not able to collect such a large amount of money in Britain; however, donations were provided by the New York Cigarmakers' Union No. 90 and the 'Belgian brethren'. ${ }^{89}$ It was collected by the recently established (December 1868) Antwerp Sigarenmakersverbond. ${ }^{90}$

The Leipzig strike was part of a strike wave that swept through Germany in 1869 and 1870 (until the outbreak of the Franco-Prussian War in July). ${ }^{91} \mathrm{In}$ 1869, of a total of 152 strikes counted by Engelhardt, 20 were by cigar-makers (13 per cent), just below the 23 by textile workers ( 15 per cent)..$^{2}$ The strike

\footnotetext{
84 Ibid., 304 .

85 Ibid., 379-387; Frisch, Die Organisationsbestrebungen, 53-58; on Lassalle's attitude towards productive associations and its positive reception among Hamburg cigar-makers, see Möller, 'Zigarrenheimarbeiter in Altona-Ottensen', 91.

86 Frisch, Die Organisationsbestrebungen, 58-59.

87 Laufenberg, Geschichte der Arbeiterbewegung, I, 368 and 402.

88 'Schreiben des Präsidenten des Allgemeinen Tabak- und Zigarrenarbeiterverbandes Friedrich Wilhelm Fritzsche in Leipzig an Karl Marx in London um den 11. Juli 1869', and 'Brief von Wilhelm Liebknecht in Leipzig an Karl Marx in London 12. Juli 1869', repr. in Institut für MarxismusLeninismus beim ZK der SED, Die Internationale in Deutschland, 374-378, and 764, n. 287. See also Engelhardt, 'Nur vereinigt sind wir stark', 935-936. The letter by Fritzsche was mentioned by Marx at the meeting of the General Council,13 July 1869: MEGA, I. Abteilung: Werke, Artikel, Entwürfe, Bd. 21, September 1867 bis März 1871 (Amsterdam, 2009), Text, 674; Apparat, 1957.

89 Engelhardt, 'Nur vereinigt sind wir stark', 936.

90 Van Laar, Geschiedenis van de Arbeidersbeweging te Antwerpen, 315-316.

91 Laufenberg, Geschichte der Arbeiterbewegung, 366 and 423-431; Welskopp, Das Banner der Brüderlichkeit, 283-284.

92 Engelhardt, 'Zur Entwicklung der Streikbewegungen', 550.
} 
wave was resumed in 1871, after the end of the war, and extended into $1872 .{ }^{93}$ Many of the cigar-makers' strikes were started spontaneously, ${ }^{94}$ also by followers of Lassalle. ${ }^{95}$ In 1871 of a total of 157 strikes in Germany, 21 were by cigar-makers; in 1872 there were again 21 (larger and smaller) cigar-makers' strikes, but out of a total of 362 ; in 1873 there were fifteen out of a total of 289. In 1874 the strike wave was clearly over: there were only 135 strikes, of which eight were by cigar-makers. ${ }^{6}$

Without doubt, the high point and the most bitter of these cigar-makers' strikes was a strike and lock-out of 2,200 Berlin cigar-makers, lasting from April to August $1872 .{ }^{97}$ To relieve the strike fund, money was collected to enable the emigration of strikers' families, even to the United States, to which in the end only five of them travelled; however, many more went to other places in Germany, most of them to Hamburg and Altona. ${ }^{8}$ The strike was also supported internationally, by funds from abroad, mostly from British trade unions. ${ }^{99}$ The strike wave was not restricted to Germany: it was a European phenomenon, also involving cigar-makers. ${ }^{100}$ Outside Germany, there were important cigar-makers' strikes in Belgium (1871) and in the Netherlands (1873).

From 1868 onwards London cigar-makers had been complaining about Belgians coming over: "There were some Belgian lodging house keepers in the East of London who imported them in such numbers that it very seriously interfered with the trade. On their first arrival they worked for anything that was offered to them. ${ }^{.101}$ Some members of the London Cigar Makers' Mutual Association proposed to leave the International because it proved unable to counteract this tendency, but they did not gain a majority in the association. ${ }^{102}$ Clearly, in the eyes of those members that wanted to leave the International, and undoubtedly also of the majority who then still

93 Laufenberg, Geschichte der Arbeiterbewegung, 477-489.

94 Cf. Frisch, Die Organisationsbestrebungen, 59 (on the cigar-makers' strikes): 'In the next strike period, stretching from mid-1871 to 1873 , it is hard to establish if the union was the official organizer, or if it was forced to participate because its members went on strike [spontaneously]. This happened, as far as I know, most of the time.'

95 Ibid., 61; Engelhardt, 'Zur Entwicklung der Streikbewegungen', $55^{\circ}$.

96 Calculated from strike tables in Machtan, Streiks und Aussperrungen, 57-447.

97 Cf. overviews ibid., 177, and Frisch, Die Organisationsbestrebungen, 65.

98 Rößler, “'Amerika du hast es besser”', 102.

99 Frisch, Die Organisationsbestrebungen, 80.

100 For the sake of brevity I can refer to MEGA, I. Abt., Bd. 21, Apparat, Einführung, 1131.

101 Ibid., Text, 593-594 and 725-726 (Meetings of the General Council 25 August 1868 and 9 November 1869).

102 Ibid., 725-726 and 743 (Meetings of the General Council 9 November 1869 and 11 January 1870). 
preferred to stay in, international organization was, or should be, useful as an instrument of labour market control. The International should help to prevent the arrival or importation of foreign - in this case Belgian - workers, and to support the establishment and activities of trade unions elsewhere to defend or improve wages and working conditions, so there would be less reason to come to Britain. It must be for this reason that James Cohn, representative of the Association in the General Council of the International, made contact with Brussels and Antwerp cigar-makers during his visit to the Congress of the International in Brussels in September 1868. In a press announcement, issued by the International after his return, it was reported:

Mr Cohn announced that during his stay at Brussels he had succeeded in getting a great many cigar-makers together who had entered into arrangements to establish a trade society and affiliate it to the International. In their present disorganised state they worked many hours more than the London cigar-makers and were miserably paid. He had been well received by them, and had no doubt that they would carry out what they had begun. At Antwerp he had been equally well received, and arrangements for the establishment of a trade society had also been made. ${ }^{103}$

In December 1868 Antwerp cigar-makers had followed Cohn's call by founding a Sigarenmakersverbond, led by the Internationalist Leopold Haesaert. It was the first 'real' trade union in Antwerp, and soon united 500 of the approximately 1,000 Antwerp cigar-makers. ${ }^{104}$ Although Haesaert and several of his co-founders of the Sigarenmakersverbond were Internationalists, after much discussion it was decided that the Verbond as such would not affiliate to the International. ${ }^{105}$ Nevertheless, contacts were made with cigar-makers in other places in Belgium, the Netherlands, Germany, and Britain. ${ }^{106}$ On 8 January 1871 a conference of cigar-makers was held in Antwerp with delegates from Belgium and the Netherlands. ${ }^{107}$

103 The Bee-Hive [London], No. 364, 3 October 1868, cited ibid., Apparat, 1896; see also the report by Cohn in the General Council, 29 September 1868, ibid., Text, 6oo. See also ibid., 749 (Meeting of the General Council 8 February 1870), and Collins and Abramsky, Karl Marx and the British Labour Movement, 171.

104 See the accounts by Van Isacker, De Internationale te Antwerpen, 69-70 and 80-88, and Van Laar, Geschiedenis van de Arbeidersbeweging te Antwerpen, 313-315.

105 Idem, 'Uit de eerste vakbeweging', 737-738; on the confusion around this issue, see Documents relatifs aux militants belges, 274, n. 1387, 293, n. 1461, and 295, n. 1469 .

106 Letter of Philippe Coenen, secretary of the Antwerp section of the International, to Karl Marx, 29 March 1871, repr. ibid., 265-266.

107 Van Isacker, De Internationale te Antwerpen, 80. 
One of its effects was the foundation of a national Dutch cigar-makers' union, the Nederlandsche Sigarenmakers Bond, shortly afterwards, on 4 February 1871 , by a combination of two older Amsterdam associations Eensgezindheid Baart Vreugde (Unity Breeds Joy) and the above-mentioned Door Vriendschap Bloeijende. There were also branches in Rotterdam, The Hague, Leiden, Utrecht, and Dordrecht. In December 1871 a total of 2,00o members was reported. Its president Jan Willem Wertwijn (1839-1899) had been present at the Antwerp conference and was a member of the International and, although there was talk of affiliation, it is not clear if this really happened ${ }^{108} \mathrm{~A}$ second Dutch-Belgian cigar-makers' conference, held in Brussels on 19 February 1871, decided to establish an international union, ${ }^{109}$ but it was December of that year before this could be realized (see below).

In March 1871 a strike by members of the Belgian Sigarenmakersverbond in an Antwerp factory led to a lock-out of 500-60o cigar-makers, the employers refusing to recognize the union and demanding that members give up their membership. In Brussels 250 strikers were locked out too. ${ }^{110}$ In the meetings of the General Council James Cohn regularly reported on the lock-out and the solidarity campaign organized by the International. As a consequence of his earlier trip, he told the council, there were now also unions in Liège and other places in Belgium, 'and from Belgium they had established unions in Holland'. Belgian and Dutch cigar-makers working in London had also formed societies and had donated money. ${ }^{111}$ To support the strikers, aid was requested internationally and was reported to have been received from Ghent, London, Liverpool, Berlin, Hamburg/Altona, ${ }^{112}$ and also from Amsterdam. ${ }^{113}$

108 Giele, De Eerste Internationale, 104 and 161; Van der Hoeven, De Nederlandse Sigarenmakers- en Tabakbewerkersbond, 19. See also Marinus and Reinalda, 'Wertwijn, Jan Willem'.

109 Van Isacker, De Internationale te Antwerpen, 129-130, n. 63.

110 Van Laar, 'Uit de eerste vakbeweging', 740.

111 MEGA, I. Abt., Bd. 22, Text, 528 (Meeting of the General Council 4 April 1871) and 539 (meeting 25 April 1871).

112 Van Isacker, De Internationale te Antwerpen, 82; see also Van Laar, Geschiedenis van de Arbeidersbeweging te Antwerpen, 318; idem, 'Uit de eerste vakbeweging', 739; $M E G A$, I. Abt.,Bd. 22, Text, 540 (meeting of the General Council 25 April 1871), 567 (meeting 20 June 1871), 578 (meeting 18 July 1871). In Britain most of the money had been contributed by the London and Liverpool cigar-makers, but there had also been a response from a wide range of other trade unions: compositors, gilders, basket finishers, tinplate workers, coopers, hatters, bookbinders, plumbers, brass finishers, elastic web weavers, bricklayers, paper-hangers, plasterers, blind makers, tailors, and furriers. See Collins and Abramsky, Karl Marx and the British Labour Movement, 219.

113 Giele, De Eerste Internationale, 118. 
Through the intervention of Friedrich Engels, who acted as the representative of Belgium in the General Council of the International, a sum of $£_{150}$ (3,750 francs) was received as a loan from the London cigar-makers, and Engels promised to do his utmost to collect money from other unions and places. ${ }^{114}$ A letter from Engels to Wilhelm Liebknecht in Leipzig, dated 4 May 1871, called for help from the Leipzig cigar-makers who, two years earlier, had been supported by the Antwerp union: 'The Antwerp cigarmakers contend that they had send 3,000 francs in support of the great cigar-makers' strike. The strike in Antwerp and Brussels is still going on, and if this is really true, then it is a damned duty of the Germans to pay this back. ${ }^{\prime 15}$ In the end Engels seems to have collected a sum of 15,000 francs, but when he found out that the Antwerp Sigarenmakersverbond was not even an institutional member of the International, he became less enthusiastic and even reproached the secretary of the Antwerp section, the shoemaker Philippe Coenen, for not having informed him properly. ${ }^{116}$

While the Antwerp union tried to save on payments by sending strikers abroad to find employment elsewhere, to Germany among others, ${ }^{117}$ the employers tried to recruit strike breakers from abroad, a few from Germany and Norway, and some girls from Strasbourg and Metz, but most of them from the Netherlands, in spite of an appeal from the president of the Dutch cigar-makers' union Wertwijn not to go to Antwerp. ${ }^{118}$ On 20 July some 20 Dutch strike breakers were molested in a tavern on the Paardenmarkt. Crowds of cigar-makers, assisted by fellow workers from other trades, men and women, accompanied the Dutchmen to the factories, and thereby

$114 M E G A, I$. Abt., Bd. 22, Text, 742 and 745, appendix I: letter by Fr. Engels to Ph.Coenen, 5 April 1871, repr. in Documents relatifs aux militants belges, 268-272; for the request by Coenen addressed to Karl Marx to support the strike, see ibid., 265-266.

115 'Brief von Friedrich Engels in London an Wilhelm Liebknecht in Leipzig 4.Mai 1871', repr. in Institut für Marxismus-Leninismus beim ZK der SED, Die Internationale in Deutschland, 225. Earlier, Engels had published a call for support in Liebknecht's paper Der Volksstaat; see ibid., 799, n. 423, and Van Laar, 'Uit de eerste vakbeweging', 745. The article is repr. in MEGA, I. Abt., $B d$. 22, Text, 11. See also 'Friedrich Engels à Philippe Coenen 5 avril 1871', in Documents relatifs aux militants belges, 268-270.

116 Letter by Engels to Coenen, 1 [4?] August 1871, repr. in Van Laar, 'Uit de eerste vakbeweging', 746-747, and Documents relatifs aux militants belges, 294-296. Nevertheless, Cohn had reported earlier, at the General Council of 9 May 1871: 'As to the affiliation it appeared that many Cigarmakers were individually members of the International but their Trade Society was not affiliated': MEGA, I. Abt., Bd. 22, Text, 548.

117 Van Laar, Geschiedenis van de Arbeidersbeweging te Antwerpen, 317; Van Isacker, De Internationale te Antwerpen, 85 .

118 Bymholt, Geschiedenis der arbeidersbeweging in Nederland, 95; Giele, De Eerste Internationale, 118. 
managed to convince them it was best to leave Antwerp. ${ }^{119}$ The strike lasted until August, when the strikers had to give in.

\section{Attempts at international union}

Although both the Belgian and the Dutch unions were founded and led by individual members of the International, in both cases it proved difficult to convince their members to affiliate to the International as organizations. There are indications that Cohn, although a member of the General Council as the president and representative of the London Cigar Makers' Association, preferred an international cooperation of cigar-makers' unions outside the International. In August 1871 the General Council had sent Cohn as its representative to Belgium to help prevent the recruitment of engineers, especially in Verviers, by the Newcastle employers to act as strike breakers in the nine-hours strike there. ${ }^{120}$ The Belgian council (Conseil générale) of the International, however, was rather annoyed about the behaviour of Cohn, because in their view he had used his visit primarily to strengthen his relationship with the cigar-makers' union in Brussels, 'not very favourable to the International, as the Brussels cigar-makers' association never wanted to affiliate, even if it had received full support of the International during the last strike'. ${ }^{21}$ At a conference of the International in London in September 1871, the secretary of the Antwerp section, Coenen, even challenged Cohn that during his visit in August he had done hardly anything to convince the Belgian engineers not to go to Newcastle; instead, he had talked a lot with the leaders of the Antwerp cigar-makers' union, but he had refused to demand that this union affiliate to the International, and had even advised against it. ${ }^{122}$

119 Van Isacker, De Internationale te Antwerpen, 83-84 and 86-87; Van Laar, Geschiedenis van de Arbeidersbeweging te Antwerpen, 318. On the strike and these incidents, see also the police reports repr. in Wouters (ed.), Documenten betreffende de geschiedenis der arbeidersbeweging: 'De procureur des konings te Antwerpen aan de procureur-generaal te Brussel, 19-23 maart 1871', 375-385, and 'De procureur des konings te Antwerpen aan de procureur-generaal te Brussel, 5 augustus 1871 ', 407-409.

120 See above n. 26, and Documents relatifs aux militants belges, 309-311: 'Alfred Herman [secrétaire correspondant pour la Belgique] aux membres du Conseil belge de l'AIT, London 9 Augustus 1871'. In this letter, the British support for the Antwerp cigar-makers' strike is invoked as an argument for the Belgians to support the Newcastle strike by preventing the recruitment of Belgian engineers. Perhaps this was the reason why Cohn was sent as a delegate.

121 Ibid., 'César De Paepe à Alfred Herman, Bruxelles, le 23 août 1871', 320-322.

122 MEGA, I. Abt., Bd. 22, Text, 747-748. 
In his own report, Cohn confirmed that he had made contacts in Belgium through the Antwerp Cigar Workers' Mutual Association (therefore, apparently not through the Conseil générale) and that, as a result of his efforts, many Belgians had been dissuaded from leaving for Britain. He had been expelled by the Belgian government on 25 August and then sent to Newcastle by the General Council, where, according to the engineers' strike leader John Burnett, many of the Belgian engineers had left as a result of 'the persuasive tongue of Mr Cohn, who sent off a batch with nearly every boat that left for the Continent'; 'by the manner in which he induced foreigners to leave Newcastle', Cohn had been 'of great service to the cause'. ${ }^{23}$

Whatever Cohn's merits in mobilizing support for the engineers' strike, these reports show that Cohn had indeed used his visit to Belgium to renew his contacts with the Belgian cigar-makers. Considering subsequent events, it seems highly probable that during his visit he had discussed the foundation of an international union apart from the International itself. In October 1871, the Dutch and Belgian unions decided to cooperate more closely to prevent strike breaking. ${ }^{124}$ Also in October, the London Cigar Makers' Mutual Association sent out a call for an international conference to be held in London in December 1871 . The conference was attended by representatives of five British unions, local Belgian unions (both Flemish- and French-speaking), Dutch unions, and also by Friedrich W. Fritzsche representing the German union. An international federation of cigar-makers' unions was formed, with the aim of organizing international support in cases of strikes. The Dutch affiliated sometime in spring, the Germans in July. ${ }^{125}$ The affiliation of the Dutch was confirmed in a national meeting held in Amsterdam on 4 and 5 August 1872, in the presence of a representative of the London Cigar Makers' Association, a Dutchman working in London named F. Neuman. It was decided to 'work towards a general combination [of cigarmakers' unions] throughout Europe into a General Tobacco Workers' Union,

123 Cited in Collins and Abramsky, Karl Marx and the British Labour Movement, 219-220. On the London Conference of 16 and 23 September 1871, see ibid., 221 and 230-232; and Katz, The Emancipation of Labor, 88-95. According to the latter, ibid., 89, 'Cohn, the Danish secretary, was totally absent, as he was preoccupied with other matters, closer to his heart', but Katz does not make clear what these matters were. Allen, et al., The North-East Engineers' Strikes, 135, write about Cohn being active in Belgium 'with modest success', but on 148-149 cite The Times, 11 September 1871 , confirming the failure of the Newcastle employers to keep hold of imported strike breakers from the continent.

124 Giele, De Eerste Internationale, 161.

125 Frisch, Die Organisationsbestrebungen, 78-80; the attendance at the London conference by the Amsterdam cigar-makers was decided in a public meeting in Amsterdam on 26 November: Giele, De Eerste Internationale, 161. 
everywhere where our trade is represented. ${ }^{126}$ So, starting from the arrival of the Belgians in London in 1868 and the actions of James Cohn in preventing them coming, a chain of events had eventually resulted in the foundation of an International Cigar-Makers' Union in 1871. The cigar-makers now started to depend on this international union to regulate their cross-border labour market, instead of the International. As there were many hesitations about joining the International in cigar-makers' unions outside Britain, they perhaps started to doubt its effectiveness in organizing international solidarity.

A second international conference was held from 28 October until 2 November 1872 in Amsterdam, with the president of the Dutch union, Jan W. Wertwijn, and the representative of the London Association, F. Neuman, as organizers. There were 32 representatives: apart from Dutchmen from Amsterdam, Rotterdam, and other Dutch cities, there were twelve from the London Association, among whom were three Dutchmen working in London, and six from Belgium (from Antwerp, Brussels, Liège, Ghent, and Bruges). ${ }^{127}$ According to the police report on which this account is based, the conference was chaired by 'a certain Van der Hout'; ; ${ }^{128}$ this must be the well-known Amsterdam Internationalist Salomon van der Hout (1843-1918), who was not a cigar-maker, however. ${ }^{129}$ The report describes Neuman and his colleagues Brandon and Loozen as 'Israelites', and as 'Dutch cigar-makers living in London', who guided the other Londoners through Amsterdam and acted as translators at the conference. It also mentions a 'Leon Hasaers' from Antwerp, probably the aforementioned president of the Antwerp union Leopold Haesaert, and a German representative with the name of 'Fritzer', in which we may recognize the president of the German union, Friedrich W. Fritzsche.

A formal effect of this international meeting was that the Dutch union from then on called itself Afdeeling Nederland van de Internationale Sigarenmakers- en Tabakbewerkersbond (Dutch Branch of the International Cigar-Makers' and Tobacco Workers' Union); ; 130 a material effect was that it discovered that Dutch cigar-makers were the lowest paid in Europe. In April 1873 a strike for a wage increase broke out in several Dutch cities

126 Cited ibid., 162.

127 Ibid.; Frisch, Die Organisationsbestrebungen, 79, mentions this second conference, but has no further information.

128 Municipal Archives Amsterdam, archief politie, 1e sectie M 336 (31 October 1872).

129 Cf. Wielsma and Becker, 'Hout, Isaac Salomon van der'.

130 Giele, De Eerste Internationale, 163; Van der Hoeven, De Nederlandse Sigarenmakers- en Tabakbewerkersbond, 19 . 
(Amsterdam, The Hague, Leiden, Delft, Utrecht, Bois-le-Duc), involving 1,500 men. As in Belgium two years earlier, the employers refused to recognize the union and locked out its members.

The prolonged strike and lock-out made a huge impression, both nationally and internationally. The General Council of the International had been moved to New York after the Hague Congress in 1872, and thereafter there is no record of workers approaching the General Council for help. Appeals from foreign workers were now directed at the separate British Federal Council of the International, formed after the London Conference of September 1871. So, in 1873 the Amsterdam cigar-makers appealed to this Federal Council for help during the lock-out. The sum collected by the London cigar-makers is said to have amounted to 33,00o Dutch guilders and was taken directly to Amsterdam by its president, Cohn, and its secretary. ${ }^{131}$ The London association helped by taking strikers to London for employment there. Money was also received from Belgium and Germany. ${ }^{132}$

The strike lasted until the autumn of 1873 and was officially called off in January 1874 . The lost strike meant the end of the activities of the International Cigar-Makers' Union, and de facto also of the Dutch sections of the International Working Men's Association. In London, however, the relief action in support of the Dutch cigar-makers in 1873 evolved into a Society for the Benefit of the Dutch (Vereeniging tot Nut der Nederlanders), with the aim of uniting all Dutchmen working in London. It was established and led by former Internationalists, who had gone to London because Dutch employers refused to employ them any longer, among whom was the aforementioned Salomon van der Hout. ${ }^{133}$ After 1873 nothing is heard of this society, but in 1877 Van der Hout became involved in an abortive attempt to re-establish the International under the name of International Labour Union (ILU). ${ }^{134}$ Is it really surprising that one of its co-founders was

131 Collins and Abramsky, Karl Marx and the British Labour Movement, 275-276. In fact, the British Federation had split in 1872 (ibid., 271), and the appeal for support had been directed to the dissident branch led by the former secretary of the London General Council, John Hales, which had some following in East London. Perhaps Cohn and his London cigar-makers' association had affiliated to this dissident branch. See also Collins, 'The English Branches', 274.

132 See the accounts in Giele, De Eerste Internationale, 217-219; Van der Hoeven, De Nederlandse Sigarenmakers- en Tabakbewerkersbond, 20; Frisch, Die Organisationsbestrebungen, 80.

133 Giele, De Eerste Internationale, 231; Bos, Waarachtige volksvrienden, 147-148.

134 Wielsma and Becker, 'Hout, Isaac Salomon van der'; Nettlau, 'Ein verschollener Nachklang'. In 1878 the ILU decided to send delegates to an international labour congress, planned by the French labour leader Jules Guesde. Guesde and 39 other French organizers were arrested and imprisoned, however, and the congress had to be cancelled. See Bernstein, The First International in America, 298, n. 25 . 
a flämischer Zigarrenmacher, named De Jong, living on Commercial Road in London's East End?'35

\section{Conclusion: the practice of internationalism}

The existence of a cross-border labour market can explain the efforts of the cigar-makers to organize internationally, but not their early trade unionism and political radicalism, both in Europe and in the Americas. The love of political discussion and the habit of 'reading', as in the cases of Cuban and German cigar-makers, cannot explain this either, if only because there are no signs of this habit in British, Dutch, and Belgian cigar factories (which does not mean that it was absent). Social historians have explained the early trade unionism and radicalization of artisans, like tailors, shoemakers, printers, cabinet-makers, shipwrights, and carpenters, by their loss of artisanal status and independent position in this period, ${ }^{136}$ but this cannot be applied to cigar-makers, because there was no artisan background or tradition in this trade. Cigar-makers were originally recruited from the poorest strata of the population. This explains the prominence of Jews in Hamburg, Amsterdam, and London. The remarks by Mayhew in the case of London around 1850, cited above, that Jewish cigar-makers had started as street sellers, and that they fell back on the traditional old-clothes trade in slack times, are clear signs of their poor backgrounds. Non-Jewish cigar-makers also came from proletarian families, as Zwahr has shown in the case of Leipzig. ${ }^{137}$ In the Dutch town of Utrecht the poverty of their families is attested to by the stature of nineteen-year-old cigar-makers measured for conscription: they were the smallest of all the occupational groups. ${ }^{138}$

In this sense, employment in a cigar factory can be considered a kind of economic emancipation from poorer conditions and, as is often true in

135 Nettlau, 'Ein verschollener Nachklang', 137. It is not clear how Nettlau found out about the Flemish origin of this De Jong. It could be that it is just his interpretation because of the name. However, the surname De Jong is extremely rare in the Dutch-speaking part of Belgium (Flanders), but very common in the Netherlands. So perhaps he was a Dutchman. Another co-founder was John Hales (see n. 131).

136 For instance Moss, The Origins of the French Labor Movement; Lenger, 'Beyond Exceptionalism'; and Chapter 3 in this volume. 'Artisan background' in this context relates to the independent position artisans had enjoyed, producing directly for customers, which in this 'artisanal phase' was being undermined by middlemen, contractors, and other entrepreneurs mediating between their work and the (more or less open) market. There is no such history of independent cigar-makers. 137 Zwahr, Zur Konstituierung des Proletariats, 93-99 and 143-145.

138 De Beer, 'Beroepskeuze, levensstandaard'. 
these cases, this became a starting point for further aspirations. In my view, the early formation of trade unions and the concomitant radical political attitude of cigar-makers can be explained by a desire for social advancement. The cigar-makers did not have an independent artisanal status to defend, but they wanted to do business with their employers about wages and working conditions (in a sense preluding Gompers' business unionism in the American Federation of Labor). They soon found out that this kind of business often meant struggle and that their position in this struggle depended on the degree of labour market control.

The international cooperation of cigar-makers, be it in the International or in a separate international union, was primarily motivated by the urgent need and rather mundane wish of the cigar-makers to regulate their crossborder labour market, not so much by an abstract ideal of international solidarity (although the talk about 'a fraternity of peoples' and 'Belgian brethren', cited above, indicates that this was not completely absent). Nor was it just based on the transfer of ideas (although the idea of forming trade unions was clearly transferred from Britain to Belgium and the Netherlands), or a perspective resulting from my aim as a historian to write an entangled cross-border history (although this approach opened my eyes to the existing transnational relationships). Much more than in the twentieth century, at the time of the First International transnational labour markets emerged quite 'naturally' as a consequence of uneven local and national economic developments in Europe (and also the United States). In the twentieth century, labour markets became increasingly organized and regulated nationally, by national social security arrangements, collective agreements, and systems of labour exchange and migration control, and, partly as a consequence, members of the working classes began to consider themselves, and were considered, to be national citizens. This, however, was not yet the case at the time of the First International. In the nineteenth century, workers moved remarkably easily, or were remarkably easily recruited, across national borders.

The pre-eminence of London as an engine of economic growth attracted workers from all over Europe, who, in the eyes of the Londoners, threatened to undermine wage standards and working conditions achieved by the London trade unions because of their strength and the favourable economic conditions in London. ${ }^{139}$ Their solution was to organize internationally, both to prevent strike breaking and wage cutting by workers from abroad, and to support unions elsewhere in raising wage standards in their home 
countries. In the case of the London cigar-makers this primarily affected the Netherlands and Belgium, and only secondarily Germany (in contrast with, for instance, the German tailors in London). Initiatives from the London cigar-makers to support trade unions and strikes were therefore primarily directed towards their Belgian and Dutch 'brethren', although relationships with and support for the German unions were not absent. From a labour market and migratory perspective, however, German cigar-makers were much more connected to the United States than to London, where Dutch, and to a lesser extent Belgian, cigar-makers mostly went.

Because of the exceptional economic growth of London (and Britain) in the 1850 s and 186 os the city became a pole of attraction for immigrants from other parts of Europe and an organizational centre for the European international workers' movement. It drew refugees and migrant workers from across the continent, who were able to think and act internationally and connect with local trade unions in the International Working Men's Association. The transnational nature of labour markets did not, of course, disappear with the demise of the International in the 1870 s. It therefore hardly comes as a surprise that in the 1880 s new attempts were made to organize labour internationally, this time from the United States. Like London, the United States continued to attract migrants on a massive scale, and for the us labour movement comparable problems arose in attempting to uphold wage standards in the face of growing competition by immigrants. As Steven Parfitt has shown, the us-based Noble and Holy Order of the Knights of Labor (established in 1869, but reaching its zenith in the 1880s) combined the wish to regulate immigration with the international cooperation of trade unions. The Knights 'viewed the Universal Brotherhood as a means to raise living standards elsewhere up to American standards. Equalizing the wages of American and European workers would render immigration to the United States unnecessary, and workers on both sides of the Atlantic would benefit accordingly.' ${ }^{140}$ It is a scheme reminiscent of the trade union policies of the First International on a smaller European scale at an earlier stage. The ideology may have been different, but the practice of internationalism had not fundamentally altered. 


\title{
3 From artisanal associations to collective bargaining agents
}

\author{
Two phases of early trade unionism in Amsterdam (1864-1894)*
}

\begin{abstract}
Since the 1970s labour historians have reflected on what Friedrich Lenger called 'the artisanal phase of the labour movement'. In the nineteenth century urban crafts underwent a gradual and partial transformation, which eroded income security and craft status. Cooperative production was considered the only way to guarantee workers the full product of their labour. The 'associational socialism' (Thomas Welskopp) of the early labour movement called for autonomous cooperatives combining independent craft producers. Such a relationship, and the idea of 'an artisanal phase', is rejected by others, such as Jacques Rancière and Iorwerth Prothero, however. In this chapter I will show that a division into two phases of the nineteenth-century labour movement can be discerned clearly and concretely in the case of Amsterdam, the capital of the Netherlands and central to the development of the Dutch labour movement. From this case I can only support the conclusions by Lenger and others about the specific artisanal nature and programme of early labour movements.
\end{abstract}

Keywords: artisans, workers' cooperatives, associational socialism, First International, carpenters, typographers, The Netherlands, Amsterdam

* Thoroughly revised and translated version of Knotter, "Van "defensieve standsreflex" tot "verkoopkartel van arbeidskracht". Twee fasen in de ontwikkeling van de Amsterdamse arbeidersvakbeweging (ca. 1870 -ca. 1895)', Tijdschrift voor Sociale Geschiedenis 19 (1993), 68-93. I thank Jan Boersma and Wil Remmers, Piet van Slooten and Anna Wits, and Dick Rietveld and Paul van Horssen, for allowing me to consult their unpublished master theses. The last two allowed me to use their database of the Amsterdam members of the Sociaal Democratische Bond, the oldest socialist party in the Netherlands (established in 1881), see also Van Horssen and Rietveld, 'Socialisten in Amsterdam'. At the Municipal Archives in Amsterdam, Gauke Jasper helped me search the population registers for the personal data of trade union officials.

Knotter, Ad, Transformations of Trade Unionism: Comparative and Transnational Perspectives on Workers Organizing in Europe and the United States, Eighteenth to Twenty-First Centuries. Amsterdam, Amsterdam University Press, 2018 DOI: $10.5117 / 9789463724715 \_$CHO3 
For labour historians it is a commonplace that the labour movement in the nineteenth century arose not among factory workers, but among craftsmen engaged in small-scale capitalist production, both skilled wage earners and self-employed workers. Commonly known as artisans, they were concentrated in urban industries and greatly outnumbered factory workers during a large part of the nineteenth century - depending on each country's economic development. Since the 1970 s historians of labour and the labour movement have reflected on what Friedrich Lenger called 'the artisanal phase of the labour movement'. Comparing artisanal labour movements in the United States, Britain, France, and Germany, Lenger argued that all developed rather similar analyses of the early capitalist economy: 'Seen from the perspective of the artisans [...] the capitalist appeared as a middleman, who - unproductive himself - stepped in between the producers [and their customers] and robbed them of part of their wages.'

In a classic definition an 'artisan' is someone producing directly on the order of his customers, ${ }^{2}$ but now he had to work under the command of brokers, contractors, or merchant-entrepreneurs, breaking into the structure of direct contact between independent producers and their customers, and mediating for a mass consumer market. Artisans (journeymen and masters alike) became dependent upon merchant-capitalists organizing a putting-out system to turn out readymade goods, or upon (building) contractors stepping in between craftsmen and their clients. From a traditional artisanal perspective these were unproductive parasites, who extorted producers and customers alike. The interests of both were perceived as fundamentally opposed to the merchant-capitalist in between. The basic diagnosis was the same everywhere, and so was the cure: producers' cooperatives were viewed as the means to end the dependency of (formerly) self-employed artisans on these parasitic middlemen. Cooperative production embodied the conviction that one could easily do without capitalists defined in this way.

\section{The artisanal phase in France, Germany, Great Britain, and the UsA}

As Bernard Moss argued in the case of France, in the nineteenth century traditional crafts underwent a gradual and partial transformation, which

\footnotetext{
$1 \quad$ Lenger, ,Beyond Exceptionalism', 17-18; see also idem, 'Die handwerkliche Phase'. An overview: Breuilly, 'Artisan Economy, Ideology and Politics'.

2 Bücher, 'Die Gewerbliche Betriebssysteme', 183.
} 
eroded income security and craft status. Skilled craftsmen still controlled much of the process of production, however. They could readily see themselves as the only real producers and their employers as superfluous parasites. In the early labour movement, cooperative production was considered the only way to guarantee workers the full product of their labour. The idea of cooperation as a means of escaping the capitalist labour market had been propagated in France already in the 1830 revolution, and the 1848 revolution saw new attempts to put it into practice. ${ }^{3}$ In the 186 os and 1870 s the establishment of cooperatives became a central part of the organized activity of French workers. Their appeal was not limited to socialists, however; radicals and liberals favoured them as well. Though not necessarily linked to the political left, and appealing to reformers from diverse ideological backgrounds, 'associationalism' was very much part of what Moss called 'the socialism of skilled workers.' ${ }^{4}$ For him

the original form of trade socialism revolved around the producers' association or cooperative, a social workshop owned and controlled by members of a trade. Arising along with the trade union in many industrializing nations, the producers' association became the main project and ultimate goal of the French labor movement. ${ }^{5}$

To what extent the idea of productive association was an article of radical faith only and really captured the minds of the artisan workforce remains subject of debate. Iorweth Prothero, who denied the existence of a distinctive 'artisan radicalism' originating from changes in the nature of work and relations at the workplace, ${ }^{6}$ argued that cooperative production was primarily used as a means to support workers during strikes or unemployment, often as a temporary device, and that the prime concerns, also for artisans, were wages and working hours. ${ }^{7}$ Sometimes cooperative production was

3 Moss, 'Parisian Producers' Associations'.

4 Idem, The Origins of the French Labor Movement, 19.

5 Idem, 'Producers' Associations', 72.

6 Prothero, Radical Artisans, 3. In his review of Radical Artisans in the American Historical Review 104 (1999), 531-532, Donald Reid points out 'Prothero's alliance with the philosopher Jacques Rancière', who had earlier criticized the idea that artisan 'associationalism' was triggered by loss of skill or status: Rancière, 'The Myth of the Artisan' (repr. in Kaplan and Koepp (eds), Work in France, 317-334), and the responses by William H. Sewell Jr. and Christopher H. Johnson, International Labor and Working-Class History 24 (1983) 17-25, Edgar Leon Newman and Nicholas Payanis, ibid. 25 (1984) 37-41.

7 Prothero, Radical Artisans, 155-166. For strike waves over wages and hours of work by artisan trade unions in England and France from the 1820s to the 186os: ibid., 69-85. 
used as a pragmatic solution by weak artisanal trade unions when wage standards seemed hard to defend by conventional strategies such as strikes. ${ }^{8}$ Nevertheless, also as a practical instrument to regulate the labour market, cooperative association could be viable as a union strategy only in the context of artisan production.

In Germany as well, the 'associational socialism' of the early labour movement called for 'autonomous cooperatives combining independent craft producers' ${ }^{9}$ From the 1840 s to the 1870 Produktionsgenossenschaften were part of a radical programme that struck a chord with small masters, journeymen, and skilled workers alike, because they enabled them to avoid fully developed wage labour by transforming elements of artisanal independence in a collective way. ${ }^{10}$ According to labour historian Thomas Welskopp, 'contemporary social democrats did not portray the entrepreneur and his autocratic domination in centralized production facilities as their prime enemies, but instead focused on the merchant-financier and controller of putting-out systems'. ${ }^{11}$ For the early German socialists, capital appeared to be an outside intruder into the world of artisan production. It had to be replaced by the voluntary association of independent workers. This changed in the 1890 s with the rise of trade unions as collective bargaining agents winning collective labour contracts with capital owners, who were now perceived as employers and not as middlemen. In this trade union environment, a new vision of industrial relations replaced the old 'associational socialism.'. ${ }^{2}$

Also in Great Britain, as Eric Hobsbawm remarked, 'the artisan's objection to capitalism [...] was not so much to working masters [...], but to the capitalist seen as an unproductive and parasitic middleman'. The theoretical foundations of early socialism were to be found in this attitude. Essentially it envisaged the elimination of competition and the capitalist by means of cooperative production. In this respect, the evolution of the British artisans ran parallel with that on the continent, especially in France. But unlike in France, cooperative socialism became a peripheral phenomenon in Britain after the 1840 s. According to Hobsbawm, this can be explained by 'the very advance of the British capitalist economy over the rest, which already made an economy of small commodity producers, individual or 
collective, somewhat implausible or economically marginal. Journeymen were workers. They lived in a world of employers. ${ }^{13}$ This is reflected in the so-called 'new model unionism' in Britain in the 1850 os and 1860s, which, as Hobsbawm remarked elsewhere, foreshadowed changes in unionism on the continent decades later (he specifically mentions Germany): 'much apparent "industrial unionism" [ ...] on the continent [in the 189os] was really the analogue of the so-called "new model" of the British unions in the 1850 o and 1860 s. $^{14}$ Exclusionary craft unionism was kept very much alive in these British 'new model unions', however. ${ }^{15}$

In the United States, the artisanal movement in favour of producers' associations was represented by the Order of the Knights of Labor (established in 1869). In its 'Declaration of Principles', article XIX, it stated: '[We will endeavor to associate our own labors] to establish co-operative institutions such as will tend to supersede the wage system. ${ }^{.16}$ The Knights believed that they could achieve emancipation from 'the tyranny of wage slavery' through cooperation. They built on 'a cooperative vision deeply rooted in the ethos of craft workers. [...] Drawn into the market as wage laborers, they formed cooperative businesses to control that market. ${ }^{17}$ In the period of its rapid growth in the 188 os cooperation made a quantum leap from prior decades, leading to roughly 500 producer cooperatives..$^{18}$ The Order's decline ran parallel with the failure to achieve collective emancipation from wage labour by cooperative production. The revival of the labour movement in the United States in the 1890 s was based on a very different concept propagated by the American Federation of Labor (AFL): trade unionism had to be 'pure and simple' and to be primarily concerned with the immediate economic interests of workers. ${ }^{19}$ In practice, however, as John Laslett observed, the 'new movement', advocated by AFL leader Samuel Gompers, 'represented little more than the reproduction on the American continent of the mid-Victorian

13 Hobsbawm, 'Artisan or Labour Aristocrat', 361-362. On the early London artisan labour movement and its relation to the idea of cooperative production: Prothero, Artisans and Politics, 250-257.

14 Hobsbawm, 'The New Unionism Reconsidered', 24.

15 Some telling examples of exclusionary unionism in the early London trade unions can be found in Thompson and Yeo (eds), The Unknown Mayhew.

16 Wright, 'Historical Sketch', 159; see also Gourevitch, From Slavery to the Cooperative Commonwealth, 118-126.

17 Leikin, The Practical Utopians, 24.

18 Ibid., 2.

19 Ibid., xix. Later to become an anti-political and anti-socialist form of 'business unionism' in the AFL, trade unionism 'pure and simple' was originally (in the 1870 s and 1880 s) motivated by the then still socialist cigar-maker Adolph Strasser (a close companion of Samuel Gompers) with reference to Marx: Gitelman, 'Adolph Strasser'. 
"new model" form of English trade unionism', mentioned above as a wage labourers' alternative to artisanal associationalism. ${ }^{20}$

It is not my intention here to reduce artisan reform attitudes to experiences of work through industrial restructuring only, and cooperative association in production was by no means the only way artisans expressed their economic interests, but the above examples do suggest that, despite national differences, the wish to at least control labour markets temporarily, but preferably to overcome exploitation more permanently, by productive cooperation was a crucial element in the strategies of the early artisanal labour movement. By propagating and forming producers' associations, radical artisans were able to turn what has often been perceived as a 'defensive status reflex' or 'backwardlooking resistance' into a programme of social reform and emancipation. ${ }^{21}$

Often established simply to counter unemployment, producers' associations were by no means necessarily part of far-reaching socialist schemes, nor were they in every case closely linked to the political left, but they always embodied the conviction that one could easily do without capitalists. In this respect there was a crucial difference with trade unionism in the next phase: while productive association by artisans was meant to 'escape', 'avoid', 'supersede', or in its radical form 'emancipate from' the capitalist wage labour market, trade unions in whatever shape and of whatever conviction emerging after the 'artisanal phase' wanted to act upon that market to regulate wages and working conditions in collective agreements bargained with employers. Their strategies were based on workers being owners of labour power, whose only prospect was to sell it on the labour market, not to restore independent production on a collective basis. For the socialist movement this resulted in a clear-cut division between the trade unions to organize the economic struggle and the political party to conquer state power as a means to enforce reforms and establish socialism. In the earlier 'artisanal' phase the programme of socialist reform or revolution and cooperative trade unionism had been inextricably linked.

\section{The Amsterdam case}

In this chapter I will show that such a division in two phases of the nineteenth-century labour movement can be discerned clearly and concretely in the case of Amsterdam, the capital of the Netherlands and central to the 
development of the Dutch labour movement. Although originating only from the 1860 s, which was rather late, like any where else the first trade unions in the Netherlands were formed by artisans such as tailors, carpenters, cabinet-makers, and typographers, who at first aimed to defend their trades against loss of status, but soon developed more advanced collective strategies of emancipation. ${ }^{22}$ Low-skilled and factory workers became involved on a massive scale from 1889 onwards only, in large strikes in, for instance, peat digging, agriculture, port labour, and textile manufacturing. These developments ran, of course, parallel with those in other countries, especially in Great Britain and Germany, where the year 1889 was a watershed in the development of mass trade unionism, known in Britain as the 'New Unionism. ${ }^{23}$ As we have seen above, 'New Unionism' in Britain was not the equivalent of a change from artisanal associationalism into a new union model, however, which Hobsbawm dated from forty years earlier.

After the turn to mass unionism in the Netherlands in the 189os, trade unions in formerly artisanal industries such as carpentry, typography, cabinet-making, and diamond processing continued to play a prominent role in the Dutch labour movement, especially in Amsterdam. Developing from or replacing older unions that had been formed a generation earlier to defend an artisanal status and propagating productive association to improve the economic position of their members, in the 1890 os a new form of unionism appeared in these trades in Amsterdam as well. These new or transformed unions primarily wanted to act in the labour market like a kind of business cartel to regulate wages and working conditions with the employers. ${ }^{24}$ In this chapter, after a short introduction into the origins and early history of the Amsterdam labour movement, I will present evidence, firstly of its artisanal character in its early phase (reaching into the late 188os) by showing that productive association was at the heart of both its liberal and its socialist branches and, secondly, of the transformation into a 'modern' kind of unionism in the late 1880s/early 189os by detailing the exemplary cases of carpenters and typographers, and relate this transformation to developments in the labour markets in these trades. Their unions were among the most prominent in Amsterdam, at least before the notorious diamond workers' union ANDB (Algemeene Nederlandsche Diamantbewerkers Bond, founded

22 Ibid. and Giele, 'Socialisme en vakbeweging', 30-31. The decline of artisan production, which explains the rise of an artisanal labour movement, occurred some 40 or 50 years later in Amsterdam than in London: Knotter, Economische transformatie, 34-37.

23 Mommsen and Husung (eds), The Development of Trade Unionism; for a thorough comparative analysis: Boll, Arbeitskämpfe und Gewerkschaften.

24 See the introduction to this volume; cf. Van Tijn, 'A Contribution to the Scientific Study'. 
in 1894) surpassed them all. In Dutch labour history the ANDB is considered to be a model trade union. ${ }^{25}$ The transition to a market-oriented strategy did take place earlier in other unions, however, which reformed themselves from or replaced older unions with an artisanal orientation from 1889 onwards.

\section{Origins and early history of the Amsterdam labour movement}

Trade unions did not arise in Amsterdam before the second half of the 186os, when artisanal societies were transformed into craft unions. ${ }^{26}$ In 1866 two typographical societies, dating from the 1840 s, set up a national union, the first in the country, called Algemeene Nederlandsche Typographen Bond (General Dutch Union of Typographers, ANTB), based in Amsterdam. Its aim was to realize a national wage tariff to prevent competition from printing workshops elsewhere in the country. Also in 1866, a union of master diamond polishers was set up, who in 1867 started a strike to lower the rent they had to pay for using grinding mills. Carpenters came together in a society Concordia Inter Nos in 1865 , at first a sick and burial fund, but later evolving into a (moderate) trade union. House painters formed a union in 1866, Vooruitgang Zij Ons Doel (Let Progress Be our Aim). Cabinet-makers transformed their mutual aid society (established in 1864) under the name Amstels Eendracht (Amsterdam's Unity) into a trade union in 1868.

In the late 1860 s a new kind of radicalism emerged. In 1869 this was reflected in strikes - until then unheard-of in the Netherlands in an urban context - by typographers and shipwrights (organized by a recently formed shipwrights' union Eendracht (Unity)), but foremost in the foundation of the Amsterdam section of the International Working Men's Association (the First international) that same year. It was meant to represent the whole of the Netherlands under the name of Nederlandsch Werklieden-Verbond, afdeeling der Internationale Arbeidersvereeniging (Dutch Workers' Union, branch of the International Working Men's Association). Many of its board members were artisans, some of them involved in the unions and strikes mentioned above, others on an individual basis: three typographers, a shipwright, a blacksmith and a mason (both working in a shipyard), a mill-hand, a tailor. 
In the following years the Amsterdam section developed a range of activities, published a newspaper, and organized mass meetings, thereby arousing the interest of artisans and workers in several branches. From 1870 members of the International were active in promoting and initiating trade unionism. A masons' union Door Eendracht t'Zaamgebracht (Brought Together through Unity) was formed by the president of the Amsterdam section Herman Smit, and a tailors' union Vooruitgang Door Broederschap (Progress through Fraternity) by the prominent Internationalist Hendrik Gerhard. In 1871 Internationalists were involved in the formation of a union of blacksmiths Recht voor Allen (Justice for All), a national union of cigarmakers, ${ }^{27}$ and a union of workers in sugar refineries. The International tried to coordinate trade union activities in a separate committee. In 1872 the committee boasted the foundation of unions of brush-makers, ship-riggers, stone masons, coopers, sawyers, basket-makers, and, most successfully, journeymen-bakers employed in bread factories. A bakers' union was formed, called Een Doel, Een Wil (One Goal, One Wish).

The radicalism of the Internationalists elicited a reaction of liberally minded and moderate trade unionists who preferred to organize nationally instead of internationally. In 1871 they formed a national federation of unions, the Algemeen Nederlands Werklieden Verbond (General Dutch Workers' Union, ANWv). Its president was the leader of the Amsterdam cabinet-makers' union B.H. Heldt, who would stay in office until 1903 and who also became a member of parliament for the Liberal Party (1885-1901). ${ }^{28}$ In Britain he would be called a 'Lib-Lab'. Under the aegis of the ANWV, national federations were formed by local unions of cabinet-makers and carpenters in 1871 and $1874 .{ }^{29}$ The ANWV represented the moderate wing of the Dutch labour movement with a liberal orientation, but this did not preclude the Amsterdam unions led by Internationalists affiliating with it. In 1872 and 1873 street demonstrations and national strikes by typographers and cigar-makers showed that the radical phase of the labour movement was not yet over, but in the years to follow the impact of the International diminished quickly. Meetings attracted fewer and fewer attendees, and trade unions lost members. Although the Amsterdam section of the International was never officially abolished, no more activities were undertaken in its name. Former members, however, remained active in societies, trade unions, and also in the ANWV, which now became the sole representative of the Dutch labour movement.

28 Op den Camp, 'Heldt, Bernardus Hermanus', 87. 
After several attempts at the formation of new societies to promote radical political ideas, in 1878 a group of former Internationalists, together with new recruits, established a Sociaal Democratische Vereeniging (Social Democratic Society) in Amsterdam, which adopted the German socialist Gotha Programme as its guide. ${ }^{30}$ In the early 1880 s social democratic societies were formed in other Dutch cities as well, and in 1882 they came together to form the first socialist party in the Netherlands, the Sociaal Democratische Bond (Social Democratic League, SDB). The membership of its Amsterdam branch grew very quickly from 30 members in 1878 to an estimated 1,000 in 1886, a year of great turmoil and unrest in the city; thereafter it lost members again. From 1885 the Social Democratic League tried to establish new trade unions on a socialist basis, but that story will be told below.

\section{Producers' associations and the early Amsterdam labour movement}

Considering the arguments by Friedrich Lenger and others on artisans preferring producers' associations as a trade union device, it is remarkable how strongly the cooperative idea was propagated in the Amsterdam labour movement around $1870.3^{31}$ On almost every occasion cooperative production was mentioned as a solution and a means to relieve the workers' plight. In this respect there were no differences between representatives of the First International or the liberal ANwv. In 1870 Hendrik Gerhard, a tailor who can be considered the ideologue of the Amsterdam section of the International, ${ }^{2}{ }^{2}$ advocated the formation of so-called work societies. Tailors who contracted work from employers on a piece rate should unite to contract collectively and divide the earnings evenly together. Actions for higher wages would in the end not result in real improvements, he thought. This solution was clearly based on tailoring as a sweated industry.33 In 1872 the tailors' union Vooruitgang Door Broederschap effectively decided to set up such a cooperative. ${ }^{34}$ One of its founders, the home-working tailor P.H.A. Schröder, an active member of the International and later of the Social Democratic League, declared several years later, in 1887, that he 'had worked years and

30 Giele, 'Willem Ansing'.

31 This section is partly based on Boersma and Remmers, 'De koöperatie'.

32 Nas, Koerier van een nieuwe tijd.

33 Van Tijn, Twintigjaren Amsterdam, $45^{8}$.

34 Ibid., 482; Boersma and Remmers, 'De koöperatie', 39; Hudig, De vakbeweging in Nederland, 158; Giele, De Eerste Internationale, 158-159 and 214-215. 
years to realize cooperative production. [...] As journeymen-tailors we wanted to contract work from the bosses collectively, to make it cooperative in a workshop established by ourselves. ${ }^{35}$

In 1872, the cabinet-makers' union Amstels Eendracht tried to organize a cooperative shop, at which cabinet-makers working at home could consign pieces of furniture to sell to the public..$^{36}$ Amstels Eendracht was associated with the ANWV. To diminish home-workers' dependency on credit provided by private furniture shops, it favoured tools and raw materials being bought collectively. Although the union was not able to realize such a cooperative shop, it remained a long-lasting desire to have one. In 1877 the members of Amstels Eendracht still deposited money on a weekly basis to enable the union to set up a producers' association. ${ }^{37}$

Also in 1872 , the journeymen-bakers' union Een Doel, Een Wil set up a producers' cooperative, after a failed action for a wage rise. ${ }^{38}$ Its efforts were part of a comprehensive cooperative project, initiated by the International, but with the involvement of some ANWV unions as well. In August 1872 the International stated that campaigns for higher wages would not result in real improvements, and that 'the executives of the trade unions [...], deliberating about ways to improve the workingmen's situation in one way or another, had found the solution in transforming all trade unions into cooperatives'. 39 The profits of the cooperative bakery 'would serve to set up a butchery, a tailors' and shoemakers' shop, and so on'. ${ }^{40}$ This clearly was an initiative of the International. Dirk Hudig, an early historian of the Dutch labour movement, reported, most likely on the basis of oral information: 'The men of the International look back on this cooperative project with some pride, and consider it one of the finest actions of the International in our country. ${ }^{41}$

The members of the International looked upon this cooperative project as a first step towards a new society. They 'wished to establish a separate working men's state within the state, which could be realized if all trade unions would collect money and set up their own factories, just like the

$3^{8}$ Van Tijn, Twintig jaren Amsterdam, 482; Boersma and Remmers, 'De koöperatie', 39-40; Hudig, De vakbeweging in Nederland, 107-108.

39 Municipal Archives Amsterdam (MAA), arch. Kabinet van de Burgemeester 1872/122; Giele, De Eerste Internationale, 213-214.

40 Ibid.

41 Hudig, De vakbeweging in Nederland, 109. 
bakers' ${ }^{42}$ It is most likely that there was a connection between this project and the cooperatives organized by the cabinet-makers and the tailors in 1872 mentioned above. The union of blacksmiths, presided over by Internationalist Willem Ansing, tried to set up a cooperative in 1872 as well. ${ }^{43}$

That this idea was still very much alive in 1874 can be concluded from a letter by the cabinet-maker and Internationalist J.Th. Potharst, saved by chance. In 1871 and 1872 he had been an organizer of trade unions for the Amsterdam section of the International. The letter reveals an outspoken artisanal mindset. The great evil in cabinet-making, in his eyes, was the employers: 'in practice, their only goal is to ask as much money as possible from the ones who provide the work [i.e., the rich clients], and squeeze the workers as much as they can'. He calls upon 'the gentlemen-clients' to bypass the existing employers and take part in a large furniture factory on a cooperative basis, set up by the cabinet-makers themselves. ${ }^{44}$

After the demise of the International, former members continued to agitate for the idea of cooperative production in unions associated with the ANwV. Under the influence of Liberal 'gentlemen' the top of the ANWV preferred consumers' cooperatives only, ${ }^{45}$ but in several unions in the ANWV the concept of producers' associations was kept very much alive. Typical ANWV unions such as the house-painters' union Vooruitgang Zij Ons Doel and the carpenters' union Concordia Inter Nos were still among its staunchest supporters. In 1877 Concordia Inter Nos founded a producers' association for journeymen-carpenters, which in the years thereafter was reported to be in a flourishing state. ${ }^{46}$

In 1878 several trade unions (among which was Concordia Inter Nos) set up a committee to promote productive association 'as the highest form of cooperation', with the aim 'to abolish the law of wages and servitude'. In their view higher wages could not be obtained by collective action and strikes; only by productive association would it be possible to break through the 'law of wages'. 47 This formula strongly recalls the German socialist Gotha

42 MAA, arch. Kabinet van de Burgemeester 1872/127.

43 Van Tijn, Twintigjaren Amsterdam, 483; Giele, De Eerste Internationale, 214.

44 't Hart, 'Brieven van J.Th. Potharst', 81.

45 Boersma and Remmers, 'De koöperatie', 41-44; Becker and Frieswijk, Bedrijven in eigen beheer, 24 .

46 Hudig, De vakbeweging in Nederland, 80; Bymholt, Geschiedenis der arbeidersbeweging, 215, 230; Boersma and Remmers, 'De koöperatie', 45; Van Slooten and Wits, '“Mijn beroep is timmerman"', 68.

47 Ibid.; Bymholt, Geschiedenis der arbeidersbeweging, 234; Boersma and Remmers, 'De koöperatie', 45-46. 
Programme with its Lassallean overtone (Lassalle famously having invented an 'iron law of wages'), which former Internationalists propagated within the ANWV. ${ }^{48}$ In 1878 the Gotha Programme was accepted as the basis of the Sociaal Democratische Vereniging (SDV), as mentioned above mainly founded by former Internationalists. The SDV considered productive association supported by the state as the only way to reach the socialist end goal. ${ }^{49}$ There can therefore be hardly any doubt that this 'Committee for productive association' was established under the influence of people who some years earlier had been active in the International. Apparently, their ideas on this issue did not differ too much from those of trade unionists associated with the ANwV.

\section{Producers' associations and the Social Democratic League}

The Gotha Programme mentioned 'the destruction of the iron law of wages' by 'the erection, with the help of the state, of socialistic productive establishments' as a step towards 'the solution of the social question'. In a letter to the German socialist leader August Bebel, published much later together with Karl Marx's well-known Critique of the Gotha Programme, Friedrich Engels remarked: 'there is absolutely no mention of the organization of the working class as a class through the medium of trade unions. And that is a point of the utmost importance, this being the proletariat's true class organization in which it fights its daily battles with capital. ${ }^{\circ}$ In the 1880 s, there was no trace of such a model in the trade union strategies of the Social Democratic League, which, under the influence of ex-internationalists, were clearly inspired by the Gotha Programme. At its inception, the League did not recognize a separate role for trade unions. Unionizing was not a means to reach an economic goal, it was the aim itself. It was to lead to a kind of centralized cooperative of all unions together. Action and strikes for economic gains made no sense and were perhaps useful only as a training exercise.

What this meant for the socialist trade unions is made clear by former Internationalist H.F. Baye, a cabinet-maker from The Hague, at that time president of the Social Democratic League, and a well-known advocate of

\footnotetext{
48 Ibid., 44; Bymholt, Geschiedenis der arbeidersbeweging, 223.

49 Boersma and Remmers, 'De koöperatie', 53-54.

50 The Gotha Programme and Karl Marx's Critique of the Gotha Programme can be found in English on the internet: https://www.archive.org/stream/GothaProgramme/726_socWrkrsParty_gothaProgram_231_djvu.txt and https://www.marxists.org/archive/marx/works/1875/ gotha/ (accessed 30-07-2016). On this issue see also Welskopp, Das Banner der Brüderlichkeit, 708-709, and Stedman Jones, Karl Marx, 556 .
} 
cooperation, ${ }^{51}$ at a meeting in January 1886 in Amsterdam of the recently established (in late 1885) socialist carpenters' union Door Eendracht Verbetering (Improvement through Unity). ${ }^{2}$ To improve social conditions he recommended cooperative association as a means to get rid of the employers. The aim of the trade unions was not to strike - that could bring no good - but cooperation and association. Associational life had to be the constitution of society, he argued; the other laws must be derived from that principle. To reach that goal the Social Democratic League wanted to set up trade unions on a socialist basis, and then 'mutually unite these unions, and these again in federations, combining among each other, in short association and centralization'. The argument was repeated in a meeting of the Amsterdam socialist cabinet-makers' union De Broederband (Brotherhood): not being able to improve working conditions, trade unions had to prepare for a society without employers by means of cooperation and association. ${ }^{53}$ It is a grandiose scheme, a headlong rush from the idea of productive association within each craft, but based on the same principles. ${ }^{54}$

As a consequence of this programme, the Social Democratic League tried to set up separate socialist trade unions. At its 1885 Christmas Conference it decided that party branches were to organize trade unions whenever there were six or more members in a trade and that these unions should join the League. ${ }^{55}$ In its trade union policy the League did not differentiate between specific economic aims of the unions in the short and socialist political goals of the party in the longer run. Trade unions had to be organized, because the League, in the words of its leader Ferdinand Domela Nieuwenhuis, considered them to be the 'germs' that 'are indispensable to prepare the socialist state. They enable, so to say, a connection to be made between the old society and the new, and to make the realization of the latter easier. ${ }^{56}$ From this perspective, it was self-evident that socialist unions should join the Social Democratic League, and thus in 1888 the League was reorganized into a federation of trade unions.

$5^{1}$ Van der Sman, 'Baye, Hermanus Franciscus'.

52 MAA, arch. politie I 1886/49.

53 Cited by Hoekman and Houkes, Het Nationaal Arbeids-Secretariaat, 87.

54 There is a striking resemblance with the German socialist programme, which propagated socialism as a kind of 'Assoziation der Assoziationen', with the aim to organize society as 'eine einzige, nur verschieden abgezweigte Productivassoziation' (cited by Welskopp, Das Banner der Brüderlichkeit, 647).

55 Hoekman and Houkes, Het Nationaal Arbeids-Secretariaat, 85.

56 Cited by Giele, 'Socialisme en vakbeweging', 61, 52-53; see also Rüter, De spoorwegstakingen, 27-28 and 48 . 
Between 1885 and 1890 the Social Democratic League proceeded to organize socialist trade unions at a local level and to combine these into national federations, even if such federations already existed in the trade concerned. ${ }^{57}$ So, in 1887 a separate Sociaal Democratische Typografen Bond (Social Democratic Union of Typographers) was established, with branches in The Hague and Amsterdam. In that same year, socialist cabinet-makers' unions in The Hague and Amsterdam united into a Nieuwe Algemeene Meubelmakers Bond (New General Cabinet-makers' Union) with a socialist orientation, apart from the already existing General Union, dominated by the Amsterdam ANWV union Amstels Eendracht. In each case, the socialist programme was more important than united action to confront the employers. Where national federations were lacking, they were formed, but only by socialist unions. An example is the Nederlandse Timmerliedenbond (Dutch Carpenters' Union), established in 1885: its Amsterdam branch was Door Eendracht Verbetering, mentioned above. The older but still existing ANwV union Concordia Inter Nos was not included. To establish producers' associations 'to effectively abolish wage labour' was the aim of socialist trade unions everywhere..$^{8}$

In this period producers' associations continued to be planned by several trade unions in Amsterdam, by both socialist and ANWV-oriented unions. The idea to establish such an association met with an enthusiastic response, for instance, in 1886 at a meeting of the union of ship-riggers Nog Tijdig Ontwaakt (Awakened in Time). ${ }^{59}$ This union was associated with the ANWV. The socialist union of shoemakers Ontwikkeling Door Eendracht (Education through Unity) opened a common workshop in $1887 .{ }^{60}$ In 1890 , in a meeting of the socialist tailors' union Voor Allen, Door Allen (For All, by All), a tailor named Schröder, whom we have met before as ex-Internationalist and advocate of cooperative production, pleaded for a cooperative workshop as an alternative for sweating. ${ }^{61}$ Also in 1890 , a cabinet-maker named Siebenlist, who was an executive of Amstels Eendracht, proposed to organize 'a cooperative cabinet-makers' association: united one could buy wood, glue, iron, and other materials, and rent one big common workshop; to act collectively could be profitable for all who join, especially for the small masters' ${ }^{62}$ In the early 1890 , ANWV president Heldt still appeared to be a staunch supporter of this idea.

7 Giele, 'Socialisme en vakbeweging', 59-61 and 65-66; Van Horssen and Rietveld, 'De SDB', 123-134; Hoekman and Houkes, Het Nationaal Arbeids-Secretariaat, 85-87.

58 Ibid., 86.

59 De Werkmansbode, 16 October 1886.

60 Bymholt, Geschiedenis der arbeidersbeweging, 473; Recht voor Allen, 15 March 1886.

61 De Werkmansbode, 15 February 1890.

62 Ibid., 22 March 1890. 
In a plea for a large collective store for cabinet-makers, he argued that this would primarily serve the small masters, and would in the long run even be 'the only means of salvation; only in this way it will be possible to compete against the big factories at the one hand, and foreign imports at the other, and also against the large warehouses that are now stocked by home-workers'. ${ }^{63}$

In these cases producers' cooperatives were meant to solve concrete problems, not to be instruments for social reform. In each case it concerned unions in artisanal trades that in the 1870 s and 188 os struggled to survive in the face of competition from more advanced methods of production. These trades - ship-rigging, shoemaking, tailoring, and cabinet-making as far as it was not factory work - were being marginalized in the depression of the 188os, without disappearing completely. The same holds true for many other traditional crafts in Amsterdam: bargemen, shipwrights, carriage- and coach-makers, gold- and silversmiths, stone masons, and so on. ${ }^{64}$ Union activity in these trades remained stuck in the artisanal phase. This can be observed primarily for unions established around 1870 and associated with the ANWV, but it was also true for the socialist unions of shoemakers and tailors. In the 188 os and 1890 os none of these unions was able to grow or flourish. ${ }^{6}$ Their marginal existence was a direct consequence of the demise of the artisanal trades in Amsterdam they represented.

\section{Reorientation and new organizing fervour around 1890}

In the second half of the 188 os there was no longer any future for trade unions that continued to orient themselves on artisanal principles and solutions, such as producers' associations. The socialist trade union programme, essentially a radical elaboration of these principles, did not put down roots either. Socialist trade unions were more like party branches to propagate socialist ideas than organizations to defend workers' interests. As far as can be determined, all trade unions, whether originating from the 1870 s or from around 1885 , had to cope with declining or stagnating memberships. A new organizing fervour arose only in 1889 and 1890 in a number of specific trades, in actions for

63 Ibid., April 1891.

64 Cf. Knotter, Economische transformatie, 128-234.

65 There is no systematic overview of the Amsterdam trade unions in the $1870 \mathrm{os}$ and $188 \mathrm{os}$. The information is gathered from Bymholt, Geschiedenis der arbeidersbeweging, from the ANWV magazine De Werkmansbode, and the socialist newspaper Recht voor Allen. For an overview of unions associated with the ANWV: Heldt, Algemeen Nederlandsch Werklieden-Verbond, 97-98. For socialist unions: Hoekman and Houkes, Het Nationaal Arbeids-Secretariaat, 85-87. 
higher wages by carpenters, house painters, typographers, and bakers. ${ }^{66}$ It is no accident that these trades experienced economic revival in those years.

The movement in Amsterdam did not evolve into mass strikes, as it did elsewhere in the country in industries associated with a Dutch variant of the 'New Unionism': the port of Rotterdam, peat cutting and agriculture in the north (Friesland), and the textile industry in the east (Twente). Before the actions in Amsterdam in 1889 and 1890 could grow into a strike movement, they petered out in the economic depression of the early $1890 \mathrm{os}$. When, however, the economy revived in 1894/95, large strikes were organized by carpenters, typographers, bakers, cabinet-makers, cigar-makers, and diamond workers. ${ }^{67}$ The one by the diamond workers resulted in the formation of the Algemeene Nederlandsche Diamantbewerkers Bond (General Diamond Workers' Union, ANDB), mentioned above. In most other trades, new national unions had previously been established. Some evolved directly from the socialist initiatives to set up trade unions in the 188 os, for instance the Metalworkers' Union (1886) and the Cigar-Makers' Union, and the Lime and Stone Masons' Union (both from 1887); others originated from a cooperation of local unions, both of socialist and of ANWV orientation. Examples are the Algemeene Nederlandsche Timmerlieden Bond (General Dutch Carpenters' Union, ANTB), established in 1892, the Algemeene Meubelmakers Bond (General Cabinet-makers' Union) and the Schildersgezellenbond (House Painters' Union), both from $1891 .{ }^{68} \mathrm{In}$ 1893, these unions combined in a new trade union federation, the Nationaal Arbeids Secretariaat (National Secretariat of Labour, NAS) ${ }^{69}$

These developments were part of a process of reorientation and redefinition of the aims and tasks of both the socialist and the liberal ANwV unions.

66 On these actions: Bymholt, Geschiedenis der arbeidersbeweging, 567, 639-641; De Werkmansbode, August 1888-September 1891; Van Slooten and Wits, “"Mijn beroep is timmerman"', 88-98; Buschman, '“Eén doel, één wil"', 101-102. See also De Werkmansbode 12 April 1890: speech by President Heldt at the annual meeting of the ANWV about the revival of trade unionism after a standstill of ten to fifteen years.

67 On these strikes: Vliegen, De dageraad der volksbevrijding, 417-419; Onderzoek naar de geschiedenis, xxiii-xlii; MAA, arch. politie I 1894/959, 1215, 1231, 1272-1299, 1314, 1361, 1364; I 1895/304, 316, 400, 412-423, 742; De Werkmansbode, August-November 1894; Rapport aangaande de Werkstaking der Timmerlieden; Van der Wal, De oudste vakbond, 87-91; Buschman, "Eén doel, één wil"', 120-123; Van der Hoeven, De Nederlandsche Sigarenmakers- en Tabakbewerkersbond, 41-46; Van Tijn, 'Geschiedenis van de Amsterdamse diamanthandel en -nijverheid', 180-183; idem, 'De Algemeene Nederlandsche Diamantbewerkersbond', 410.

68 Onderzoek naar de geschiedenis, introduction; De Werkmansbode, 1890, 1891, 1892, 1893; Recht voor Allen, 1891; Van Slooten and Wits, '“Mijn beroep is timmerman"', 139-156; Buschman, “'Eén doel, één wil"', 104-115.

69 On the formation of this first trade union federation in the Netherlands: Hoekman and Houkes, Het Nationaal Arbeids-Secretariaat, 120-140. 
Many unions, or at least majorities in each of them, broke away from their political or politicized parent organizations. This process originated in the movement in Amsterdam around 1890, mentioned above, and would result in the trade unions gaining independence to orient primarily on the economic interests of their members..$^{7^{\circ}}$

Amsterdam being the centre of Dutch unionism in the skilled trades, developments there left a mark on the trade union movement in the country as whole and its relationship with the Social Democratic League. ${ }^{71}$ In the next sections I will examine these developments in detail in two exemplary cases, those of the carpenters and the typographers. Before the rise of the diamond workers' union in 1894, their unions were the largest in Amsterdam. In 1890, the socialist carpenters took the initiative to liberate their union Door Eendracht Verbetering from its ties with the Social Democratic League, and this opened the way to independent economic action, together with the older carpenters' union Concordia Inter Nos. The history of the carpenters' movement is illustrative for developments in other trades.

\section{The carpenters' movement (186os-189os)}

Concordia Inter Nos was founded in 1865 as a sick and burial fund and developed into a typical artisanal trade union. Professional pride was one of its guiding principles. ${ }^{72}$ Its membership grew from 150 in 1868 to around 1,000 in 1876 (Table 3.1 ). Its origins and growth can be considered a reaction to the disruption of artisanal labour relations in the building industry by the system of contracting and subcontracting during the period of urban expansion after 1873, when Amsterdam experienced a building boom. The growth of contracting introduced unrestricted competition in an industry which until then had been governed by custom and by trusted relationships between clients, master builders, and journeymen. ${ }^{73}$ Now construction works were carried out by contractors who had to bargain over the price

70 Willem Vliegen, historian of and participant in the early socialist movement in the Netherlands, remembered the years 1888-189o as an 'era of the rise of trade unionism. [...] Trade unions started to live their own, independent life, and were no longer as inseparable from the socialist movement as they had been at the time of the International and after': Vliegen, De dageraad der Volksbevrijding II, 8o, 9o. See also on this reorientation: Hoekman and Houkes, Het Nationaal Arbeids-Secretariaat, 88-89.

71 Ibid., 260-301; also Buschman, “"Eén doel, één wil”', 104-110.

72 Van Slooten and Wits, “'Mijn beroep is timmerman”', 72 and 78.

73 Ibid., 70-79; Knotter, 'De Amsterdamse bouwnijverheid', 138-144. 
in an open market for real estate, and to adapt to this market workers were increasingly hired on a casual basis. Artisans in civil construction working on fixed contracts and a daily wage were replaced by pieceworkers, who subcontracted work from employers on a temporary basis for the duration of the job. The demise of artisanal labour and the rise of (sub)contracting freed the labour market from customary relations. The personal bond between master and journeymen was increasingly replaced by the act of buying and selling labour power. There is a clear relationship between this change in labour relations and the growth of Concordia Inter Nos as a trade union in the 1870 s. Concordia tried to defend the former artisanal status of building workers. Its growth continued until the first great building crisis in 1877. Thereafter membership went down and there were hardly any activities anymore.

Table 3.1 Membership of the Amsterdam carpenters' unions Concordia Inter Nos (1868-1893) and Door Eendracht Verbetering (1885-1893)

\begin{tabular}{lcc}
\hline Year & Concordia Inter Nos & Door Eendracht Verbetering \\
\hline 1868 & 150 & \\
1870 & 300 & \\
1872 & 275 & \\
1874 & 400 & \\
1875 & 600 & \\
1876 & 1,000 & 160 \\
1884 & 200 & 134 \\
1885 & & $600^{*}$ \\
1887 & 130 & $700-1,000$ \\
1890 & & 500 \\
1890 & & \\
1891 & 150 & \\
1893 & 200 & \\
\hline
\end{tabular}

* After separation from the Social Democratic League.

Sources: Van Slooten and Wits, 'Mijn beroep is timmerman', 58; Recht voor Allen, 4 February and 21 May 1891; Onderzoek naar de geschiedenis, xxxiii

The second carpenters' union, Door Eendracht Verbetering, was founded by social democratic carpenters in 1885 and was affiliated with the Social Democratic League until the autumn of $1890 .{ }^{74}$ Originally, it had been part of the movement to establish separate socialist unions, but in the late 
188 os several of its members became dissatisfied with this approach. In 1888 these members set up a so-called Neutral Committee that started to campaign for higher wages and a reduction in working hours. ${ }^{75}$ This initiative reflected a change of opinion among social democratic carpenters, who now wanted their trade union to defend workers' interests more concretely and to act as a wage-bargaining agent. In 1889 and 1890 , this formally 'neutral' committee, whose members were in fact all socialists, organized several meetings, petitions, and other public actions for these goals, and succeeded in gaining a large following among the Amsterdam carpenters in this way. Stimulated by this success, in 1890 Door Eendracht Verbetering decided to break away from the Social Democratic League and to transform itself into a 'neutral' or 'general' union. As a consequence, the followers of the Neutral Committee joined Door Eendracht Verbetering. After the break, its membership immediately rose from 134 to 6oo, and climbed even higher in the next year (Table 3.1). Some 30 members did not agree, however, and established a separate socialist union named Constantia. ${ }^{76}$ This union held on to the original trade union policy of the Social Democratic League, but the debate continued in Door Eendracht Verbetering as well: in 1891 some members still wanted to establish producers' associations 'to eliminate the employers as useless middlemen', while others stressed the importance of a 'class struggle' to raise wages and reduce working hours. ${ }^{77}$

After the breakaway from the Social Democratic League, Door Eendracht Verbetering tried to realize a general or neutral federation of carpenters' unions in the country as a whole. It succeeded in doing so in 1892 with the foundation of the Algemeene Nederlandsche Timmerlieden Bond. $7^{8}$ National federation was deemed necessary because of the increasing national integration of carpenters' labour markets since the 1880s: especially in Amsterdam immigration of building labourers was on the rise and replacing older seasonal forms of circular migration in specific segments of the building labour market..$^{79}$ During its 1890 wage campaign the Neutral Committee had explicitly warned carpenters elsewhere in the country not to come to Amsterdam to prevent them from being used by employers to depress wages. ${ }^{80}$

75 On this 'Neutral Committee' also Hoekman and Houkes, Het Nationaal Arbeids-Secretariaat, 99-100.

76 Ibid., 100-101; Recht voor Allen, 26 January, 4 and 17 February, 12, 21 and 30/31 May, 15 June and 15 July 1891.

77 Cited by Hoekman and Houkes, Het Nationaal Arbeids-Secretariaat, 103.

78 Ibid., 108-109.

79 Knotter, Economische transformatie, 109-113.

8 o De Werkmansbode, May 1890. 
Figure 3.1 Carpenters at the construction of the Paleis voor Volksvlijt (Palace of People's Industry), Amsterdam, c. 1862

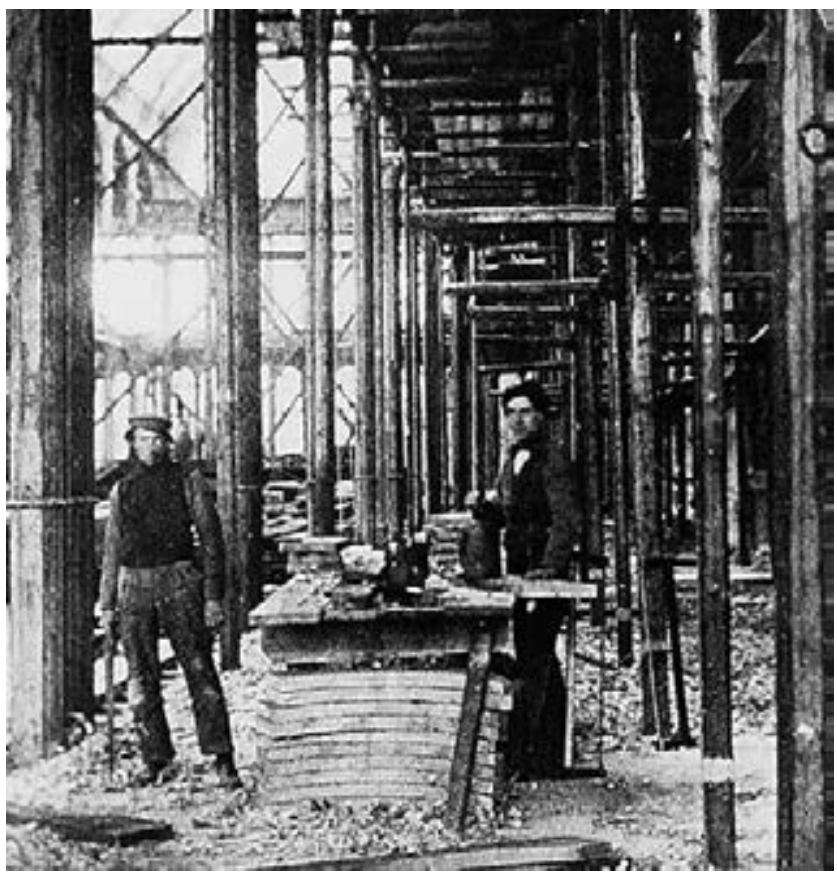

Collection City Archives Amsterdam

Because of increasing migration, Door Eendracht Verbetering was forced to interfere with the national labour market and to try to regulate wages and working conditions nationally. This explains its efforts to unite the carpenters nationally, regardless of their ideological orientation or background.

The Amsterdam branch of the Algemeene Nederlandsche Timmerlieden Bond was formed by the older unions Concordia Inter Nos and Door Eendracht Verbetering, which both continued to exist as separate societies, with a joint membership of 700 in 1893 (Table 3.1) ${ }^{81}$ The national leadership of the Algemeene Nederlandsche Timmerlieden Bond for a large part consisted of the same persons who in 1889 had initiated the Neutral Committee, the breakaway of Door Eendracht Verbetering from the Social Democratic League, and its transformation into a wage-bargaining union. A prominent member of this group was Piet Verdorst, who in 1892 became president of the newly established national union. In 1905 he became one of the co-founders 
of the new Nederlandsch Verbond van Vakvereenigingen (Dutch Federation of Trade Unions, NVV), together with Henri Polak of the diamond workers' union. Verdorst stayed on the NVv's executive board until $1920 .{ }^{82}$

All this makes clear that the change in trade union policies of the carpenters described above represented a crucial moment in the development of trade unionism in Amsterdam and in the Netherlands as a whole. It marked the end of the artisanal phase of the labour movement. The episode sparked a fierce argument in the Social Democratic League about the role of trade unions in the social democratic movement, which in the end would result in a total reversal of the relationship between the party and the trade unions when in 1893 a national federation of trade unions was formed under the name Nationaal Arbeids Secetariaat. The League now became affiliated to this trade union federation instead of the other way around. ${ }^{83}$ So there are good reasons to analyse the backgrounds of the changes in the Amsterdam carpenters' movement around 1890 more thoroughly.

\section{Two kinds of trade unionists in the Amsterdam building trades}

To understand the evolution of carpenters' trade unionism from artisanal associations to wage-bargaining agents, it is necessary to have a closer look at developments in the building trades in the 1880 s. $^{84}$ The building boom associated with the urban expansion of Amsterdam from the end of the $1860 \mathrm{os}$ reached its peak between 1879 and 1883 . The employment created by this building boom attracted a wave of immigrants, in particular from the Dutch provinces of North-Holland (north of Amsterdam) and Friesland (in the north of the country, but within easy reach by crossing the Zuiderzee, now IJsselmeer, by boat). Immigrants were recruited by jerry-builders and contractors because labour supply in Amsterdam fell short, but also because the artisanal training of the Amsterdammers did not fit the building methods in speculative building dominant in housing development in the new urban quarters. In this kind of construction, workers were casually employed on piece rates in an open labour market. There are many indications that in the 188 os old-fashioned artisanal relations continued in the renovation and maintenance of existing buildings as a separate but shrinking segment in the labour market, mainly employing

82 Sprenger, 'Verdorst, Pieter Marinus'. The NVV is a direct precursor of today's Dutch trade union federation FNV.

83 Hoekman and Houkes, Het Nationaal Arbeids-Secretariaat, 120-140.

84 Cf. Knotter, Economische transformatie, 93-118. 
Table 3.2 Place of birth of board members and militants active in unions in the building trades and construction workers in the SD League not known as union members, 1873-1894

\begin{tabular}{|c|c|c|c|c|}
\hline \multirow[b]{2}{*}{ Board members/militants of } & \multicolumn{2}{|c|}{ Active before 1885} & \multicolumn{2}{|c|}{ Active after 1885} \\
\hline & $\begin{array}{l}\text { Born in } \\
\text { Amsterdam }\end{array}$ & $\begin{array}{l}\text { Born } \\
\text { elsewhere }\end{array}$ & $\begin{array}{l}\text { Born in } \\
\text { Amsterdam }\end{array}$ & $\begin{array}{c}\text { Born } \\
\text { elsewhere }\end{array}$ \\
\hline \multicolumn{5}{|l|}{ Carpenters' unions } \\
\hline Concordia Inter Nos (1873-1894) & 7 & & 9 & 3 \\
\hline $\begin{array}{l}\text { Door Eendracht Verbetering } \\
(1885-1894)\end{array}$ & & & 18 & 20 \\
\hline \multicolumn{5}{|l|}{$\begin{array}{l}\text { Painters', masons', plasterers' } \\
\text { unions* }\end{array}$} \\
\hline Affiliated to anwv (1873-1894) & 12 & 5 & 5 & 2 \\
\hline Affiliated to sd League (1885-1894) & & & 6 & 10 \\
\hline \multicolumn{5}{|l|}{ Total building trades } \\
\hline affiliated to anwv & 19 & 5 & 14 & 5 \\
\hline Affiliated to sd League & & & 24 & 30 \\
\hline $\begin{array}{l}\text { Members of SD League in the } \\
\text { building trades (not known as } \\
\text { union members) (1885-1894) }\end{array}$ & & & 22 & 32 \\
\hline
\end{tabular}

* ANwv: plasterers: Eendracht Maakt Ons Sterk (Unity Makes Us Strong); masons: Door Eendracht t'Zaamgebracht (Brought Together through Unity); painters: Vooruitgang Zij Ons Doel (Let Progress Be our Aim). sD League: painters: Door Eendracht Sterk (Strong Through Unity); masons: Vrijheid en Recht (Freedom and Justice); stone masons: Door Verbroedering Verbetering (Improvement through Fraternity); Amsterdamsche Stukadoorsvereniging (Amsterdam Plasterers' Union) (together these form the Amsterdam branch of the Dutch Lime and Stone Masons' Union, est. 1886). Sources: Data collected in the Amsterdam Population Registers of board members and militants mentioned in De Batavier, 1873, and Jaarboekje van het ANwV, 1877-1894; De Werkmansbode, Recht voor Allen, De Timmerman, 1891; addresses by trade unions in Municipal Archives Amsterdam, arch. Publieke Werken 1891; database, Van Horssen and Rietveld, 'Socialisten in Amsterdam'

Amsterdam-born artisans. In housing development by jerry-builders, by contrast, most of the workers were immigrants, who for the largest part had arrived in Amsterdam during the peak of the building boom in the early 1880 s.

Personal data of board members and activists in Amsterdam builders' unions affiliated to the Liberal ANWV and the Social Democratic League could be collected from the Amsterdam Population Registers (Table 3.2) and, although the numbers are small (perhaps too small for a representative sample), the differences are nonetheless striking. All militants from the ANWV-oriented artisanal carpenters' union Concordia Inter Nos active 
Table 3.3 Year of birth of board members and militants active in unions in the building trades and construction workers in the SD League not known as union members, 1873-1894

\begin{tabular}{|c|c|c|c|c|}
\hline \multirow[b]{2}{*}{ Board members/militants of } & \multicolumn{4}{|c|}{ Years of birth } \\
\hline & $\begin{array}{c}\text { Before } \\
1850\end{array}$ & $1850-1859$ & $1860-1869$ & Total \\
\hline \multicolumn{5}{|l|}{ Carpenters' unions } \\
\hline Concordia Inter Nos & 11 & 6 & 2 & 19 \\
\hline Door Eendracht Verbetering & 5 & 19 & 14 & 38 \\
\hline \multicolumn{5}{|l|}{ Painters', masons', plasterers' unions } \\
\hline affiliated to anwv & 23 & 1 & & 24 \\
\hline Affiliated to sd league & 4 & 5 & 7 & 16 \\
\hline \multicolumn{5}{|l|}{ Total building trades } \\
\hline affiliated to anwv & 34 & 7 & 2 & 43 \\
\hline Affiliated to sd League & 9 & 24 & 21 & 54 \\
\hline $\begin{array}{l}\text { Members of sD League in the building } \\
\text { trades (not known as union members) }\end{array}$ & 15 & 23 & 16 & 54 \\
\hline
\end{tabular}

Sources: see Table 3.2

before 1885 were born in Amsterdam; after 1885 this is still the case with nine out of twelve. A majority of activists in Door Eendracht Verbetering, by contrast, were born elsewhere, and thus were part of the immigrant workforce in the Amsterdam building trades. The same pattern can be recognized in other unions of building workers (masons, plasterers, painters), and among members of the Social Democratic League who held a job in construction, but could not be identified as union members: ${ }^{85}$ members of ANWV unions were primarily born in Amsterdam; social democrats were mostly immigrants.

Apart from their origin, there was also a clear generational difference between the active members of the ANWV-oriented and socialist unions (Table 3.3): the first ones were generally older (in all building unions associated with the ANWV 79 per cent were born before 1850; in the socialist unions 83 per cent were born after that year). The militants of the ANWV had most likely become active in the early years of trade union activity in

85 These data were originally collected by Paul van Horssen and Dick Rietveld for their article 'Socialisten in Amsterdam', and kindly provided to me for this research. 
Table 3.4 Year of arrival of board members and militants born outside Amsterdam active in the socialist unions in the building trades, and of construction workers in the SD League not known as union members, 1885-1894

\begin{tabular}{lccr}
\hline Arrival year & $\begin{array}{c}\text { Activists in } \\
\text { socialist unions }\end{array}$ & $\begin{array}{c}\text { Members of the sD League in the building } \\
\text { trades not known as union members }\end{array}$ & Total \\
\hline Before 1880 & 4 & 8 & 12 \\
$1880-1883$ & 15 & 14 & 29 \\
$1885-1887$ & 3 & 4 & 7 \\
After 1887 & 4 & 5 & 9 \\
Unknown & 4 & 1 & 5 \\
Total & 30 & 32 & 62 \\
\hline
\end{tabular}

Sources: see Table 3.2

the late 1860 s and early 1870 , but had not been able to attract or activate new members in the 188 os. This birth cohort was not completely absent in the socialist unions (as there was still a group of former Internationalists), but most of their active members had become involved in the 1880 s as young people.

The migrants in the socialist building unions and among the members of the Social Democratic League working in construction had primarily arrived at the peak of the building boom between 1880 and 1883 (47 per cent; see Table 3.4), so they had taken part in the general migration wave to Amsterdam in this period. Their provenance was also very much like those of migrants in general: North-Holland and Friesland were the most prominent among the provinces of birth (Table 3.5).

These differences between active members of socialist and ANWV unions reflect different positions of Amsterdam-born artisans and migrant workers in the labour market in the building trades. Concordia Inter Nos continued to represent the older, more or less protected but shrinking artisanal segment; Door Eendracht Verbetering primarily organized younger migrants who were employed in jerry-building in housing development. They did not cherish artisanal traditions or professional pride; they were wage workers subject to the vagaries and uncertainties of an open labour market. Their prime interest was to control and regulate that market. Representatives of this group broke with both the traditions of artisanal trade unionism and the union policies of the Social Democratic League, which, under the influence of former Internationalists and in accordance with the German Gotha Programme, essentially consisted of a radical continuation of the 
Table 3.5 Province of birth of board members and militants born outside Amsterdam active in the socialist unions in the building trades, and of construction workers in the SD League not known as union members, 1885-1894

\begin{tabular}{lccr}
\hline Province & $\begin{array}{c}\text { Activists in } \\
\text { socialist unions }\end{array}$ & $\begin{array}{c}\text { Members of the sD League in the building } \\
\text { trades not known as union members }\end{array}$ & Total \\
\hline Groningen & 2 & 10 & 2 \\
Friesland & 5 & 1 & 15 \\
Drenthe & 1 & 3 & 2 \\
Overijssel & & 3 & 3 \\
Gelderland & 4 & 4 & 7 \\
Utrecht & 1 & 5 & 5 \\
North-Holland & 12 & 2 & 17 \\
South-Holland & 2 & & 4 \\
Zeeland & 1 & & 1 \\
North-Brabant/ & 1 & 32 & 1 \\
Limburg & 1 & & 62 \\
Unknown & 30 & & 1 \\
Total & & & \\
\hline
\end{tabular}

Sources: see Table 3.2

artisan approach. Their initiative to act as Neutral Committee, to break away from the Social Democratic League, and to unite all unions regardless of their ideological background to regulate the carpenters' labour market, both in Amsterdam and in the country as a whole, opened the way for a new type of trade union organization, and marked the end of the artisanal phase in the Dutch labour movement.

\section{The typographers}

The example of the carpenters showed that the resurgence of the Dutch labour movement from about 1889 - not only in 'New Unionism'-type sectors, but also in the skilled trades - was caused by new groups of workers, who in fact had no relation with older artisanal traditions of union organization. In my second example, the typographers' union, there was an analogous development.

The Amsterdam branch of the Algemeene Nederlandsche Typografen Bond (General Dutch Union of Typographers) was formed in 1866 out of two older typographical societies, Voorzorg en Genoegen (Precaution and 
Table 3.6 Membership of the Amsterdam branch of the Algemeene Nederlandsche Typografen Bond, 1866-1869 and 1889-1895

\begin{tabular}{llll}
\hline Year & \multicolumn{3}{c}{ Year } \\
\hline 1866 & 248 & 1889 & 220 \\
1867 & 197 & 1890 & 250 \\
1868 & 186 & 1891 & 300 \\
1869 & 140 & 1892 & 387 \\
1870 & $* *$ & 1893 & 488 \\
& & 1894 & 577 \\
& & 1895 & 598 \\
\hline
\end{tabular}

** Until 1888 numbers were said to be 'declining and languishing'.

Sources: Van der Wal, De oudste vakbond, 248-249; Onderzoek naar de geschiedenis, xxxiii

Satisfaction) and Onderling Hulpfonds Boekdrukkunst (Mutual Relief Fund Typography). ${ }^{86}$ At its inception artisanal pride was an important motive. A lively period in the 1860s was followed by stagnation and decline (Table 3.6). There were new signs of life in 1887 , when, in accordance with trade union policies of the Social Democratic League, socialist typographers organized a separate Sociaal Democratische Typografen Bond (Social Democratic Union of Typographers). In one year the Amsterdam branch of this union is reported to have grown from 80 members to $200 .{ }^{87}$ Members of the Social Democratic Union also joined the General Union and soon gained influence there ${ }^{88}$ Membership of the Amsterdam branch increased again and at the annual meeting in the autumn of 1887 it was decided to sever ties with the ANWV, to which the Union had been affiliated since 1871. In 1888 young socialists succeeded in taking over the executive board of the Amsterdam branch, and in 1889 also the national board.

After these takeovers the Union became more active and radical. As a matter of fact, the new board members acted just like the socialist carpenters in the Neutral Committee. In 1890 a committee was set up, consisting of members of the Amsterdam branches of the General and Social Democratic Unions of Typographers, and also of the typographical society Voorzorg en Genoegen, still affiliated with the ANWv. ${ }^{89}$ Its aim was to regulate wages and

86 Van der Wal, De oudste vakbond, 17-26; Giele, De Eerste Internationale, 22-28; idem, 'Het ontstaan van de typografen-vakorganisatie'.

87 Bymholt, Geschiedenis der arbeidersbeweging, 520.

88 Van der Wal, De oudste vakbond, 69.

89 De Werkmansbode, June, July 189o, September 1891. 
Figure 3.2 Boys labour in the Senefelder printing works, Amsterdam, c. 1900

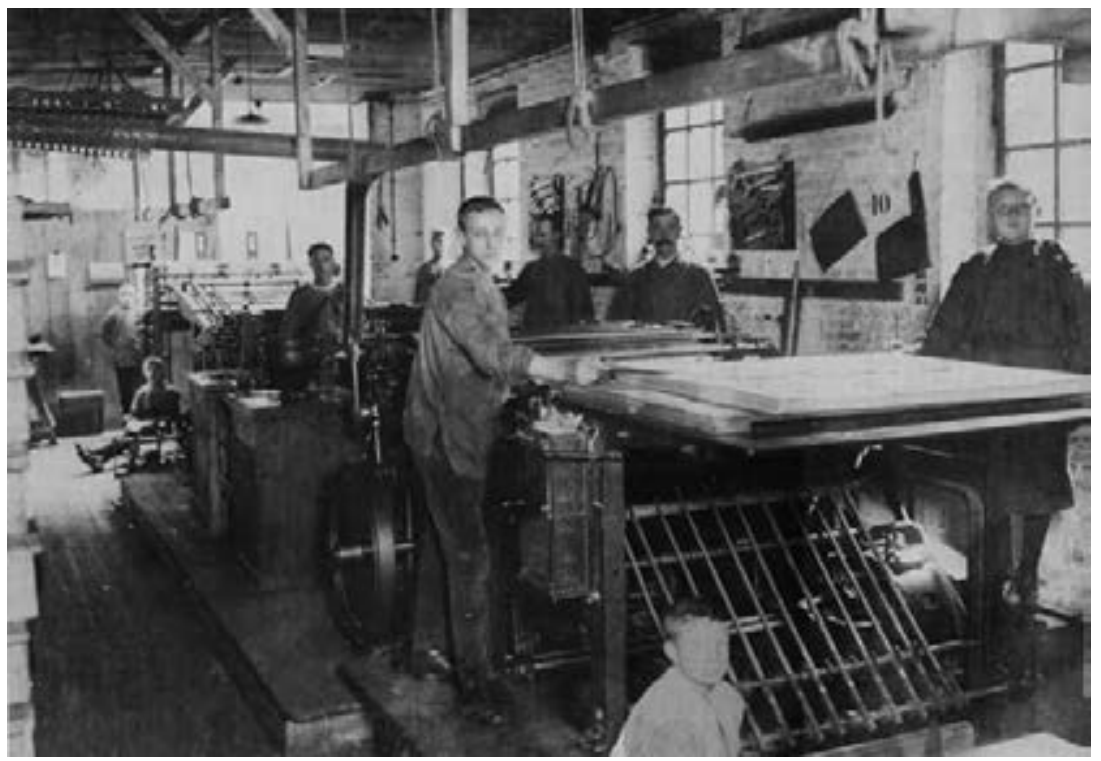

Collection City Archives Amsterdam

hours of work with the employers. In 1890 and 1891 there were also (abortive) attempts to arrive at a broader coalition with typographical societies in the country that until then had kept aloof from the General Union. ${ }^{90}$

This new fervour went together with an increase in membership of the Amsterdam branch of the General Union (Table 3.6). ${ }^{91}$ According to its president Adriaan Rot, the new members consisted of young workers, employed by large printing establishments. ${ }^{92}$ Earlier there had been few union members there. The growth of membership paralleled the increase in employment in the printing industry in the late 1880s, especially in the large establishments. The demand for typographers in this sector met a supply of young workers, who in the years before had been employed and trained in small printing workshops. ${ }^{93}$ This circumstantial evidence indicates that the

90 Ibid., 12 April 189o, March 1891; Van der Wal, De oudste vakbond, 73-78; Bymholt, Geschiedenis der arbeidersbeweging, 637-639.

91 Membership before 1889 remains unknown, but in 1888 the union counted only 200 members nationwide in four branches, including Amsterdam: Bymholt, Geschiedenis der arbeidersbeweging, 515 .

92 Enquête gehouden door de Staatscommissie, 425-426 (interview with A. Rot, typographer). On Rot, see Scheffer, 'Rot, Adriaan'.

93 Knotter, Economische transformatie, 139-146. 
Table 3.7 Year of birth of board members of the Amsterdam branch of the Algemeene Nederlandse Typographen Bond and in the typographical societies De Nederlandsche Drukpers and Voorzorg en Genoegen (affiliated to the ANwv), before and after 1889

\begin{tabular}{lcccc}
\hline & \multicolumn{4}{c}{ Years of birth } \\
\cline { 2 - 5 } Board members of & Before 1850 & $1850-1859$ & $1860-1869$ & Total \\
\hline $\begin{array}{l}\text { Algemeene Nederlandse } \\
\text { Typographen Bond }\end{array}$ & 16 & 1 & 2 & 19 \\
$\begin{array}{l}\text { Before 1889 } \\
\text { After 1889 }\end{array}$ & 2 & 4 & 7 & 13 \\
$\begin{array}{l}\text { De Nederlandsche Drukpers/ } \\
\text { Voorzorg en Genoegen }\end{array}$ & 11 & & & \\
$\begin{array}{l}\text { Before 1889 } \\
\text { After 1889 }\end{array}$ & 4 & 4 & & 11 \\
\hline
\end{tabular}

Sources: Data collected from the Amsterdam Population Registers of board members and militants mentioned in De Batavier, 1873, Jaarboekje van het Anwv, 1877-1894, and Van der Wal, De oudste vakbond

growth of the typographical union in those years was based on this category of workers. Just as in the carpenters' case, these new initiatives were taken by a new group of workers in new segments of the labour market, who had no experience with the artisanal origins of the typographers' union in the 1860s. Table 3.7 illustrates the generational differences of the board members of both the union and the typographical societies. Clearly, after 1889 there was a new generation involved. In the traditional artisanal societies there was hardly any generational change.

\section{Conclusion: two phases, two generations}

The examples analysed above showed that the emergence of a new type of trade unionism was supported by new groups of workers who in the $188 \mathrm{os}$ were recruited for an open wage labour market. In that period old established artisanal industries in Amsterdam were in decline and were superseded by new forms of industrial organization with a new kind of labour relations. During the 1880 s this development reached a turning point: the artisanal industries were marginalized without completely disappearing. ${ }^{94}$ The 
transition from artisanal associationalism, aimed at superseding or leaving the wage labour market altogether, to trade unionism, aimed at regulating and controlling that market, ran parallel to this development. From their experiences with labour market developments during the depression of the 188 os, new groups of workers concluded that regulation of the 'free', unrestricted labour market was necessary, and that this could be achieved only by collective institutions to protect workers against its vagaries and uncertainties. Newly arrived workers started to organize such institutions without the burden of the artisanal past of their predecessors. As soon as the depression of the 188 os was over and economic growth seemed to enable them to reach some success, they tried to organize trade unions as wage-bargaining agents.

This break was realized by new groups of workers in and outside the Social Democratic League, who in large part belonged to a new generation in the labour movement. ${ }^{95}$ As with generational change in general, it was not age itself that was decisive in their choice to do so, but the collective experience of new age groups with labour market change. This becomes clear from a comparison between the carpenters and the typographers. The carpenters who in the late 188 os became active in the so-called Neutral Committee were generally some ten years older than the typographers who initiated the renewal of the typographical union in the same period. Most of the carpenters were born in the early $1850 \mathrm{~s}$, most of the typographers in the early 1860 s. The explanation can be found in the time lag in the recruitment for the new labour markets: the peak of recruitment for speculative building was about ten years earlier than the rise of employment in the large printing establishments. That both groups of workers started to unionize at the end of the 188 os was a consequence of the short economic revival in those years. Trade union activity in the earlier deep depression was not possible.

In a broader perspective, generational change was also clearly visible in the social composition of the members of the two main antagonists in the Amsterdam labour movement: board members and militants of all Amsterdam branches of trade unions affiliated to the ANWV, originating around 1870 in the artisanal phase, and of the Social Democratic League, which in 1881 started as an initiative of an older generation of Internationalists, but in the 188 os managed to attract new groups of workers. ${ }^{96}$ Table 3.8 shows that in general the members of the ANWV were older than those of the

95 On the importance of generational change in the labour movement: Blok, et al. (eds), Generations in Labour History; Schönhoven and Braun (eds), Generationen in der Arbeiterbewegung. 96 Van Horssen and Rietveld, 'De Sociaal Democratische Bond', 42-44. 
Table 3.8 Age structure of active members of the Social Democratic League and the ANwv before and after 1885 (percentages)

\begin{tabular}{lcccc}
\hline \multirow{2}{*}{ Years of birth } & \multicolumn{2}{c}{ Before 1885 } & \multicolumn{2}{c}{ After 1885 } \\
\cline { 2 - 5 } & SD League & ANwv & SD League & ANwv \\
\hline Before 1820 & $2.5 \%$ & $6.6 \%$ & $0.6 \%$ & $1.1 \%$ \\
$1820-1829$ & $9.9 \%$ & $25.6 \%$ & $3.1 \%$ & $18.2 \%$ \\
$1830-1839$ & $16.1 \%$ & $21.5 \%$ & $4.8 \%$ & $8.0 \%$ \\
$1840-1849$ & $32.1 \%$ & $38.8 \%$ & $19.1 \%$ & $34.1 \%$ \\
$1850-1859$ & $30.1 \%$ & $6.6 \%$ & $38.2 \%$ & $31.2 \%$ \\
$1860-1869$ & $8.6 \%$ & $0.8 \%$ & $29.6 \%$ & $5.7 \%$ \\
After 1869 & & & $4.6 \%$ & $1.1 \%$ \\
N= & 81 & 121 & 351 & 88 \\
\hline
\end{tabular}

Sources: Database of members of the Amsterdam branch of the sd League by Van Horssen and Rietveld, 'Socialisten in Amsterdam'; data collected in the Amsterdam Population Registers of board members and militants in all Amsterdam trade unions affiliated to anwv, mentioned in De Batavier, 1873 and Jaarboekje van het ANWv, 1877-1894

League, both before and after 1885 . Before 1885 leading members of the ANWV for a large part belonged to the birth cohort of the 1840s, or even earlier. These were the men (there were no women involved) who had established the artisanal unions in the late 186 os and early 1870 . This cohort is well represented in the Social Democratic League as well, but unlike in the ANWV there were only few who were born before 1840: most of this older group was born in the $1850 \mathrm{~s}$. These were the members of the International who were still active in the late 1870 s and who established the League in 1881 .

The age structure of the ANWV shows that after 1885 the affiliated unions gained or activated very few members born in the 1860 os or later. This must have been clearly visible in the composition of their meetings. At the annual meeting in 1888, for instance, there was a complaint that younger members were absent, and that only 'the most advanced in years stayed faithful.' 97 After 1885 the Social Democratic League gained many new members, by contrast. It explains the growth of the birth cohorts from the $1850 \mathrm{os}$ and 186os. Information on the occupations of new members is available, and it is striking that building workers were very prominent among them, especially in the period $1885-1887$, just like casual workers. Together these occupational groups accounted for 50 per cent of new members of the Social Democratic League in those years. ${ }^{98}$ This one-sided social composition was 
a consequence of the agitation by the Social Democratic League among unemployed workers in the 1880s. Unemployment in Amsterdam was concentrated precisely both in construction and among casual workers (who were often former building workers). ${ }^{99}$ When building revived at the end of the $188 \mathrm{os}$, those new recruits became the proponents of the new trade union policy described above. In the next period, between 1888 and 1895 the share of typographers among the newly recruited members of the Social Democratic League rose significantly from 2.3 to 8.3 per cent. ${ }^{100}$ It is obvious that this was related to the reorientation and revival of the typographers' union in this period.

In this study I have demonstrated that in the early development of the labour movement in Amsterdam two different phases can be clearly distinguished. It did not develop in a continuum from artisanal protest and associational cooperation to collective agency to regulate wage labour markets. Views, opinions, strategies, and organizational forms in the artisanal phase differed fundamentally from trade union policies after the demise of artisan production and the rise of mass wage labour markets. These changes were brought about by new generations in the labour force, who broke with older orientations in both the liberal and the socialist labour movement. From this case I can only support the conclusions by Friedrich Lenger and others about the specific artisanal nature and programme of the early labour movement in other countries in Europe and the United States, and cannot agree with Iorwerth Prothero's and Jacques Rancière's refusal to recognize such a separate artisanal phase, cited in the introduction to this chapter.

99 Knotter, Economische transformatie, 115-116, 137-138, 241-242.

100 Van Horssen and Rietveld, 'Socialisten in Amsterdam', 400. 


\title{
4 Trade unions and workplace organization
}

\author{
Regulating labour markets in the Belgian and American \\ flat-glass industry and in the Amsterdam diamond industry \\ (c. 1880-1940)*
}

\begin{abstract}
In the nineteenth century in many manufacturing industries, the organization of the labour process took the form of internal subcontracting. The emergence of craft unions was often closely related to this system. These unions aspired to control labour markets for an elite of skilled workers. Craft unions emerged in the nineteenth century, but from the end of that century and in the first decades of the twentieth they were increasingly replaced by industrial unions organizing workers in a branch as a whole. While relationships between developments in the labour process, i.e. internal subcontracting and its demise, trade unionism, and labour markets have been clearly established in the steel, shipbuilding, and engineering industries (mostly in Britain and the USA), research on these issues in other industries is rare. In this chapter, I compare developments in the American and Belgian window-glass industries and in Amsterdam diamond processing from three perspectives: the development of craft unions in evolving systems of subcontracting; the impact of the demise of subcontracting on established craft unions and the emergence of industrial unions as a consequence; and the struggle of trade unions to regulate product markets and industrial competition through labour market control.
\end{abstract}

Keywords: subcontracting, craft unionism, industrial unionism, industrial relations, transnationalism, regulatory unionism, diamond processing, window glass manufacturing

* Reprinted from Ad Knotter, 'Trade Unions and Workplace Organization. Regulating Labour Markets in the Belgian and American Flat Glass Industry and in the Amsterdam Diamond Industry (c. 1880-1940)', Labor History 57 (2016), 415-438.

Knotter, Ad, Transformations of Trade Unionism: Comparative and Transnational Perspectives on Workers Organizing in Europe and the United States, Eighteenth to Twenty-First Centuries. Amsterdam, Amsterdam University Press, 2018 DOI: 10.5117/9789463724715_CHO4 
In the nineteenth century in many manufacturing industries, the organization of the labour process took the form of internal subcontracting. ${ }^{1}$ As a kind of continuation of independent artisans commissioned by customers, craftsmen subcontracted the work to be done in factories, engaging auxiliary workers themselves and paying their wage bill from overall earnings negotiated with the factory owner or the company. According to American, British, and French labour historians, somewhere near the end of the century internal subcontracting was gradually replaced by a system of salaried foremen supervising an hierarchically organized workforce, whose wages were paid directly by the company that had engaged them individually as workers. ${ }^{2}$ There were different kinds of internal subcontracting, and the system had not been universally applied, but these authors agree that at the end of the nineteenth century a transformation of industrial organization was on its way, which in the early twentieth century would evolve into elaborate systems of management control, such as Taylorism.

In the system of internal subcontracting, a craftsman made an arrangement with a factory owner to execute a certain task, or produce a certain amount of goods, at the premises of the factory for an agreed sum of money. The company supplied the building, machines, and raw materials, owned and sold the finished product, and perhaps coordinated the production process as a whole, but the subcontractor organized his part of production, and coordinated and supervised workers hired by himself to assist him or to cooperate with him. This kind of internal organization accommodated the specialized character of factory work and in many cases also its origins from independent artisanal labour. In a workplace organization built upon supervision by foremen, by contrast, the whole of the workforce, including the foremen themselves, were engaged or dismissed by the company, for wages that were centrally determined for the company as a whole.

Eric Hobsbawm regarded the system of internal subcontracting as 'a transitional stage in the development of capitalist management'. He proposed to call this phenomenon 'co-exploitation'. Hobsbawm differentiated between subcontracting proper, widely prevalent in the iron and steel industry, iron shipbuilding, parts of coal mining, and small-scale workshops, and 'the more general form of skilled workers hiring or paying their unskilled, or

1 Van den Eeckhout (ed.), Supervision and Authority, 1-33.

2 Nelson, Managers and Workers; Clawson, Bureaucracy and the Labor Process; Littler, The Development; Gospel, 'The Development', 91-110; Englander, 'The Inside Contract System'; Lefèbvre, L'invention de la Grande Entreprise. Some interesting studies on French cases are: Scott, The Glassworkers of Carmaux; Reid, The Miners of Decazeville. 
skilled workers being paid by results while their helpers were paid on time'.3 This was prevalent in cotton, the potteries, the mines, and in one form or another in most industries in which piecework obtained. Elsewhere, this variant has been called the 'helper system': skilled factory workers engaged auxiliary workers, often wives, children, or other family members, whom they themselves paid to assist them, for instance in the manufacturing of glass and earthenware, and in textiles. ${ }^{4}$ Within this system, helpers were trained to become skilled craftsmen.

The emergence of craft unions in the nineteenth century was often closely related to systems of internal subcontracting. These unions aspired to control labour markets for an elite of skilled workers. Many early British trade unions were craft societies of internal subcontractors, who also organized and paid for the work of their helpers and auxiliary workers. Their exclusiveness often brought them into conflict with their underlings, however, and revealed the 'co-exploitive' character of the system. A salient example is the Iron Workers' Union. A day-wage iron worker testified in 1892: 'The contractor is the man who gets his labour at the very lowest he can, and the consequence is that he takes the substance while the workers themselves go home with the shadow. We find it a great grievance to the men. ${ }^{5}$

Technological changes in the British steel industry strengthened the position of auxiliary workers, however, who in 1886 formed a separate Steel Smelters Union. This union opposed the system of internal contracting and thereby came into conflict with the Ironworkers' Union. Contracting was finally eliminated by the effective organization of the auxiliary workers in this Smelters Union. ${ }^{6}$ First-hand observers Sidney and Beatrice Webb reported about conflicts between a newly formed (in 1877) Union of Platers' Helpers and the older Boilermakers' Society in shipbuilding, which could be explained because: 'The Platers' Helpers constitute a large class of labourers in shipbuilding yards, who are usually employed and paid, not by the owners of the yards, but by members of the Boilermakers' Society.7 The helpers earned daily wages, but the amount of work done was determined by the speed of their bosses (the platers), who were paid by the

3 Hobsbawm, 'The Labour Aristocracy', 297-300 and 353. For a broader view on subcontracting in industrializing Britain: Pollard, The Genesis of Modern Management, 51-63.

4 Van den Eeckhout (ed.), Supervision and Authority, 9; Nelson, Managers and Workers, 38-39; Clawson, Bureaucracy and the Labor Process, 94-97. On the helper system as a variant of internal contracting in the USA, also: Ulman, The Rise of the National Trade Union, 468-470.

5 Cited in Elbaum and Wilkinson, 'Industrial Relations and Uneven Development', 291.

6 Ibid., 292; Littler, The Development, 68 and 77; Welskopp, 'Le Syndicalisme', 59.

7 Webb and Webb, History of Trade Unionism, 353-354. 
piece. Helpers complained that only the platers profited from this system. ${ }^{8}$ Clyde shipbuilder William Denny, cited by the Webbs, remarked in 1886 that this was not unusual:

There is [...] a mixed kind of piece work in which skilled workmen employ labourers at time wages to do the unskilled portion of their work for them. [...] Instances occasionally occur in which the skilled workmen treat their labourers, either intentionally or unintentionally, with harshness. ${ }^{9}$

The Webbs add: 'The members of the great race of sub-contractors in all industries are always trying to employ time workers, in order to obtain for themselves the fullest possible advantage of their own driving power. ${ }^{10}$ In the USA, it was likewise reported that the employees 'often bore the brunt' when contractors' piece rates were reduced, and that inside contracting 'invited petty tyrannies.' ${ }^{11}$ In the steel industry, diverging interests between puddlers or rollers and their helpers could result in strikes of the latter against their masters. ${ }^{12}$

Trade unions of subcontractors were typically craft unions that defended a specialist, artisanal status and relatively high wages against employers and, if needed, also against their inferiors, as the above examples make clear. Craft unions emerged in the nineteenth century, but from the end of that century and in the first decades of the twentieth they were increasingly replaced by industrial unions organizing workers in a branch as a whole, instead of a specific craft or occupation. One of the reasons was the change in workplace organization, mentioned above, which meant that personnel were increasingly employed as general wage workers, and began to experience and articulate common interests in industrial relations. These kinds of general unions wanted to include as many co-workers as possible to gain a stronger position in their negotiations with employers, while craft unions had tried to control craft labour markets by excluding outsiders.

In the United States, trade unions were often hostile to political and ideological influences - like those of socialism or Christian democracy in Europe. Unions tended to concentrate on the economic aspects of wage

8 For a detailed account of this issue: McClelland and Reid, 'Wood, Iron and Steel'. See also Robertson, 'Demarcation Disputes'.

9 Cited by Webb and Webb, Industrial Democracy, 295-296.

10 Ibid., 303.

11 Nelson, Managers and Workers, 36-37.

12 Welskopp, Arbeit und Macht, 163. For a general treatment of this problem in the USA: Ashworth, The Helper. 
bargaining only, in what is commonly known as 'business unionism. ${ }^{13}$ Trade unions acted as if they were a business cartel regulating supply and pricing in the labour market. A consequence could be that they cooperated with employers in what has been called 'regulatory unionism': employers recognized that strong unions and uniformly negotiated wages could serve as important means of regulating labour costs across an industry, especially in disorganized industries unable to achieve market stability otherwise. ${ }^{14}$ Strong unions and collective agreements were used to equalize labour costs and to discipline or eradicate marginal competitors. In the American window-glass industry, this kind of regulatory unionism was already prevalent in the nineteenth century. Employers used unions of skilled workers to take wages out of the competition and restrict the entry of new competitors in a profitable and protected industry. ${ }^{15}$

While relationships between developments in the labour process, i.e. internal subcontracting and its demise, trade unionism and labour markets have been clearly established in the steel, shipbuilding, and engineering industries (mostly in Britain and the USA), ${ }^{16}$ research on these issues in other industries is rare. Existing literature on the history of industrial relations and trade unionism in the American and Belgian window-glass industries and in the Amsterdam diamond industry enabled me to explore changes in workplace organization and the evolution of trade unionism in these industries in a comparative way. ${ }^{17}$ In this chapter, I will highlight developments in these industries from three perspectives: the development of craft unions in evolving systems of subcontracting; the impact of the demise of subcontracting on established craft unions and the emergence of industrial unions as a consequence; and the struggle of trade unions to regulate product markets and industrial competition through labour market control. How

Hattam, Labor Visions

14 Gordon, New Deals, 87-97. For a vivid description of the practice of regulatory unionism in Los Angeles, see Milkman, LA Story.

15 Gordon, New Deals, 110.

16 Stone, 'The Origins of Job Structures'; Elbaum and Wilkinson, 'Industrial Relations and Uneven Development'; Montgomery, The Fall of the House of Labor, 12-20, 41-42, 120, 187-188; Fremdling, 'The Puddler'; Welskopp, Arbeit und Macht, 126-44; Welskopp, 'Le syndicalisme'.

17 Industrial relations in the American window-glass industry have been studied by Fones-Wolf, Glass Towns. See also idem, 'From Craft to Industrial Unionism'. Still relevant is Davis, The Development. On the Belgian window-glass industry, see De Ridder, 'Loonsystemen'; Delaet, 'La méchanisation de la verrerie'; Lefèbvre, La Verrerie à Vitres. On the Amsterdam diamond industry: Van Tijn, 'De Algemeene Nederlandsche Diamantbewerkersbond'; idem, 'Geschiedenis van de Amsterdamse diamanthandel en -nijverheid'; idem, 'De Amsterdamse diamanthandel en -nijverheid'. 
and under what circumstances were unions able to achieve that goal, and what were the particular forces in each industry that broke it apart?

This is all the more interesting as there were many relationships between the American and Belgian window-glass industries, primarily because of migration of Belgian flat-glass workers to the United States. From the 1880 s, hundreds of highly skilled glass-workers from the centres of Belgian windowglass making around Charleroi moved to places near Pittsburgh, where the American flat-glass industry was initially concentrated, and later also to places elsewhere in the United States, such as Clarksburg in West Virginia. ${ }^{18}$ They kept in contact with their home country and heavily influenced the formation of trade unions in the American branches of the industry. Amsterdam diamond workers established many links with Antwerp, which in the late nineteenth and early twentieth century started to compete with Amsterdam to the extent that in the twentieth century it outstripped Amsterdam as a centre of the diamond trade. International trade union cooperation was not able to prevent the proliferation of low-wage work in Antwerp and its surroundings.

\section{Craft unionism and internal subcontracting in the us window- glass industry}

Until the 1830s, in Us window-glass making glass-blowers acted as coordinators of production as a whole. In that period the 'gathering' of molten glass was done by boys as assistants and apprentices; later this task developed into the separate craft of 'gatherers'. In some cases, these were still paid by the glass-blowers. A 'gatherer' picked a certain amount of molten glass from the oven with a blowpipe, and handed this over to a 'blower' to blow a cylinder out of it. The cylinders were then cut lengthwise, flattened by a 'flattener', and cut into prescribed pieces by a 'cutter'. 'Flattening' and 'cutting' turned into independent crafts as well. In the 1860 s separate unions emerged for each of these crafts in Pittsburgh, then the centre of window-glass manufacturing in the United States. In 1879 and 1880 these unions came together in Local Assembly 300, Knights of Labor, Window Glass Workers of America, which quickly became a national organization, negotiating the terms and conditions for 1,500 skilled workers at annual meetings with the employers. ${ }^{19}$ 
Figure 4.1 Cutting glass-cylinders in a Belgian window-glass factory

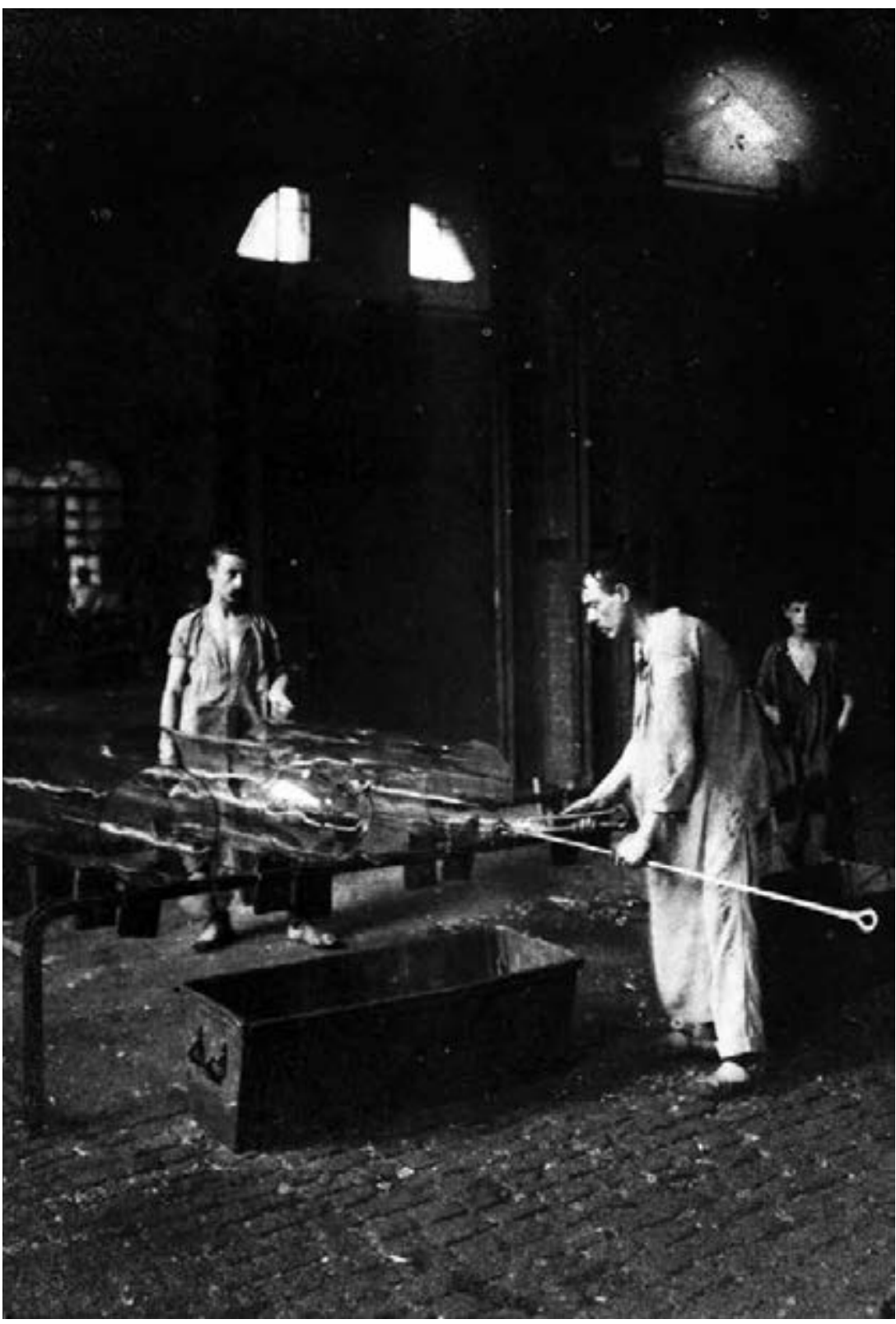

Collection Musée du Verre de Charleroi. Used with permission 
Figure 4.2 Interior of the window-glass factory Verreries du Centre in Jumet, Belgium, date unknown

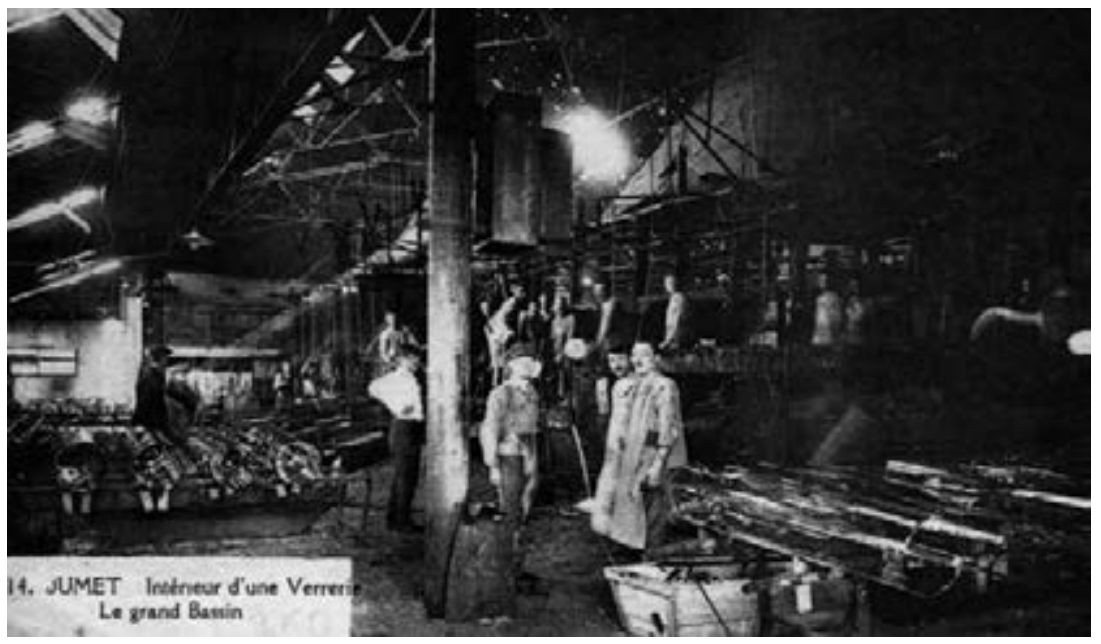

Collection Musée du Verre de Charleroi. Used with permission

Artisanal production of flat glass was centred around the master glassblower (or 'gaffer'), who was assisted by a team of craftsmen and several helpers. In this artisanal phase of the industry, the role of auxiliary workers was limited to transport and storage of the glass in support of the gatherers and blowers. 'Carry-in boys' carried hot finished pieces to the annealing furnace, and 'carry-out boys' or 'snapper-up boys' transferred the cooled, annealed pieces to the storage room and prepared them for transport. There were also 'mold-boys', 'stick- or middle-boys', and 'bit-boys'. ${ }^{20}$ That these helpers were called 'boys' is a clear indication that they originally had been sons or other youthful kin, who in this way were introduced into the trade to become craftsmen in later life. As they were paid by the glass-workers themselves, this workplace organization was clearly based on a 'helper system', mentioned above as a variant of internal subcontracting. The flatteners' helpers, called 'shove-in boys', were paid by the flatteners as well, and helpers and bosses could oppose each other, for instance in a strike in Pennsylvania by the shove-in boys in 1899 that was broken by the flatteners. $^{21}$ 
It is not completely clear how long the helper system in the window-glass industry could be maintained. The introduction of the continuous tank in the 1890 s and further mechanization in the years to follow changed the profile of the helpers. Their duties and numbers increased, and they were now considered workers instead of apprentices. They were no longer recruited from - mostly Belgian - immigrant families of skilled workers, but from the native population and from unskilled immigrants from southern and eastern Europe. So, there were ethnic differences as well. ${ }^{22}$ 'Snapper' became a general term for helpers of the blower. Because of technological change, snappers began performing more and more tasks, and as the demand for snappers rose, men rather than boys were recruited, who would spend their entire working life in the job. Glass-blowers paid 'snappers' from their own income, and therefore tended to keep their wages low: 'No one can exploit a common working man, that is a common laborer, like a skilled workman', a contemporary observer remarked on this case. The snappers tried to gain admission to the unions of skilled workers in the window-glass industry, but the union consistently denied them access and even cooperated with the employers to prevent the snappers from organizing for better working conditions. ${ }^{23}$

\section{Regulatory unionism}

Before mechanization began in the 1890 s, craftsmen and their craft union Local Assembly 300 (LA 300) were able to control the production of window glass to a great extent. Only gatherers, blowers, cutters, and flatteners were allowed to become members of this union. They formed a true labour aristocracy, as they accounted for only 40 per cent of the total workforce in window-glass manufacturing and earned almost three times as much as unskilled workers in the industry. ${ }^{24}$ With the help of their union, these specialized workers greatly influenced working conditions and workplace organization. By limiting the number of apprentices and crew size they were able to control entry to their crafts and thereby labour supply. They even succeeded in coming to terms with the employers on the amount of glass produced in the industry as a whole. For this reason, LA 300 has been 
described as 'one of the most powerful labor unions in the history of the United States'. ${ }^{25}$

From 1880, the employers were united in the American Window Glass Manufacturers Association. Through this association they were prepared to comply with the regulatory unionism of LA 300 because, in this artisanal phase of industrial development, it was quite easy to start a new glass factory. It was in their interest to prevent the entry of new producers by limiting competition over wages and working conditions, but they were able to realize this goal only with the help of the trade union: 'companies maintained their market share because the union effectively regulated the ability of companies to enter the industry through its control of skilled labor'. ${ }^{26}$ This dual monopoly of employers' and workers' organizations - regulating production and prices, and allowing high wages for craft workers - was made possible by high import tariffs protecting the American market against foreign (mainly Belgian) competition. It would be maintained for 20 years.

LA 300 negotiated production, price setting, and rules of labour with the employers. To prevent oversupply, apprenticeship was limited to family members, and the number and learning period of apprentices were strictly regulated. In the early 188 os, attempts by the employers to recruit skilled immigrants from Belgium were opposed in a successful strike, and it was Local Assembly 300 that in 1884 had the power to determine that 600-70o Belgian window-glass workers were allowed entry into the expanding us industry. The transnational labour market of window-glass workers induced LA 300 to extend its reach into an international union, the Universal Federation of Window Glass Workers of the World, which included branches in Belgium in the Charleroi area, and in England (in St. Helens and Sunderland), the two principal areas of window-glass manufacturing in Europe. ${ }^{27}$

The window-glass workers of the United States wanted to include fellow craftsmen in Europe in an international organization to regulate the transnational labour market of window-glass workers. The object was 'to prevent the carrying of persons in our trade from one country to another, and, if possible, to regulate wages. It is to see that there are not too many people in any one locality at any one time.' In 1880, two members of LA 300 were sent to Europe to 'ascertain why so many window glass workers come

27 Ibid., 132; Fones-Wolf, Glass Towns, 121; idem, 'Transatlantic Craft Migrations', 302-305; idem, 'Immigrants, Labor and Capital', 63-66; De Ridder, 'Loonsystemen', 106-107, 117; Lefèbvre, La Verrerie à Vitres, 64-65; Parfitt, 'Brotherhood from a Distance', 477-478; Pelling, 'The Knights of Labor'. On the Knights in St Helens, see also Barker, The Glassmakers, 178-18o. 
to America under contract for less than current wages, and, if possible, have the European workers form a union and establish a closer communication between America and the old country, in order to protect the interest of all window glass workers'. ${ }^{28}$

Through the Universal Federation of Window Glass Workers of the World, LA 300 was able to regulate the transatlantic labour market by restricting or permitting admission of English or Belgian glass-workers to the United States according to the needs of the labour market, and by supporting trade unions and strikes in Europe. Contacts in Europe were facilitated by the migration of union activists from England and Belgium to the United States. ${ }^{29}$ One of the more intriguing figures in this transatlantic mobility and unionization is the Belgian window-glass worker Albert Delwarte (1847-1913), who became secretary of the Universal Federation, and travelled through Britain and the United States to sustain transnational unionism. As a labour activist, Delwarte personified a continuity in internationalism from the International Working Men's Association (the First International) to the Knights of Labor. ${ }^{30}$ In 1867 , at the age of 20 , he had joined and become active in the First International in Belgium. In 1884, he was the main organizer of the Union Verrière (see below) in the Charleroi district. In 1885 he visited Pittsburgh, became a member of the Knights of Labor, and was selected as secretary of the Universal Union. In 1895 , he settled in the window-glass making town of Jeannette and, supported by the Belgian colony there, became one of the leading figures in the francophone Socialist Party. ${ }^{31}$

\section{A craftsman's paradise: producers' associations in the American window-glass industry}

In January 1901, a group of Belgian glass-workers opened a cooperative window-glass factory in Clarksburg, West Virginia, called the Clarksburg Cooperative Window Glass Company. ${ }^{32}$ In the following years, several other

\footnotetext{
28 Both quotations from Pelling, 'The Knights of Labor', 314-315.

29 Ibid., 316-319.

30 On this continuity: Parfitt, 'Brotherhood From a Distance', 474; idem, 'The First-and-a-half International'; see also Chapter 2 in this volume. From the window-glass workers, the influence of the Knights of Labor radiated to the miners in the Charleroi area, where a miners' union was successfully formed under its aegis. Its undisputed leader, Jean Caluwaert (1846-1918), had been a member of the First International as well. See Michel, 'La Chevalerie du Travail'.

31 Cordillot, La social en Amérique, 150-152.

32 Fones-Wolf, Glass Towns, 124.
} 
cooperative window-glass factories were established In Clarksburg, mainly by glass-workers from Belgium. These cooperatives proved to be successful and attracted more and more Belgians, including newly arrived immigrants. Belgian migrants established producers' associations in flat-glass making in other states and places in the United States as well: in West Virginia (Mannington, South Charleston), in Pennsylvania (Point Marion, Uniontown), and in Indiana (Matthews, Marion, Dunkirk).33 Between 1910 and 1920, the share of Belgian migrants in skilled jobs in us window-glass manufacturing rose significantly. They mainly worked in the cooperative factories and stayed in close contact with colleagues and kin in their home country. The presence of skilled glass-workers from Belgium, and to a lesser extent from France, Germany, and England, turned places like Clarksburg into a kind of craftsman's paradise in the first decade of the twentieth century. Politically, the glass-workers in the cooperative factories were often oriented towards socialism, but their convictions were not very strong: during the First World War these were easily exchanged for American patriotism. ${ }^{34}$

Several authors have discovered a relationship between the enthusiasm for cooperative producers' associations in the early (socialist) labour movement and changes in the social status of skilled, semi-independent artisans, brought about by changing relations of production and mechanization. Bernard Moss considered it to be a manifestation of 'the socialism of the skilled workers' in nineteenth-century France, and Friedrich Lenger deemed it a characteristic feature of what he called 'the artisanal phase of the labour movement' 35 Lacking ownership of the means of production, but still possessing the property of their craft in trades where workers controlled the process of production, these 'associationists' felt perfectly able to do without their employers, whom they considered superfluous parasites standing between between producers and customers. ${ }^{36}$ The producers' associations established by the Belgian migrants in the American window-glass industry fit seamlessly into this pattern. They reacted to the mechanization of the industry since the $1890 \mathrm{os}$, at first by the increasing use of the continuous tank (in French four à basin), and after 1903 also by the introduction of cylinder glass-blowing machines. These developments

Idem, 'Transatlantic Craft Migrations', 309.

Ibid., 304; idem, Glass Towns, 53, 124-135, 139; idem, 'Immigrants, Labor and Capital', 73-74.

35 Moss, The Origins of the French Labor Movement; see also idem, 'Parisian Producers' Associations'; idem, 'Producers' Associations'; Lenger, 'Beyond Exceptionalism'. See for the German case Eisenberg, Frühe Arbeiterbewegung. Producers' associations were typically part of what Welskopp calls 'associational socialism': 'The Vision(s) of Work'. For the Amsterdam case, see Chapter 3 in this volume.

36 Moss, 'Parisian Producers' Associations', 78-79. 
undermined the central position of the skilled workers, especially of the glass-blowers and the gatherers (in French ceullieurs). ${ }^{37}$ These specialists left the mechanizing factories and established producers' associations. They used their prominent position in Local Assembly 300 of the Knights of Labor to support the establishment of these cooperatives financially..$^{38}$

In 1907, a National Window Glass Workers' Union was founded as a continuation of Local Assembly 300.39 In general, craftsmen in the cooperative factories became members of this union. Approximately one-third of its members were of Belgian descent. Their original orientation towards socialism did not preclude an exclusionary outlook: as in LA 300 access to the union was limited to the skilled craftsmen in window-glass manufacturing: gatherers, blowers, flatteners, and cutters. Semi-skilled and unskilled workers, like snappers and other auxiliary workers, were not admitted to the union, despite their regular appeals to be allowed. When snappers went on strike in 1916, the blowers and gatherers even took over their tasks until the strike was defeated. ${ }^{40}$ The producers' associations in the windowglass industry were able to survive the competition of the mechanized factories until shortly after the First World War. During the war, private companies introduced machines that produced flat glass directly, without having to blow glass cylinders first (the so-called Libbey-Owens process). As a consequence, only glass-cutters remained as skilled workers in the mechanized factories. The cooperative factories, which operated on the basis of craftsmanship, were no longer able to compete: in 1920 they had all disappeared. From now on, window glass was produced only by private, mechanized companies. Many of the skilled workers from the cooperatives had to take up low-skilled work in the mechanized factories. ${ }^{41}$

\section{Demise of the 'dual monopoly' and the rise of industrial unionism}

The introduction of the continuous tank in the 1890s, the relocation of the industry to places where natural gas was available (such as West Virginia),

37 Davis, The Development, 182-184.

38 Fones-Wolf, Glass Towns, 29-33, 54, 122-123.

39 Ibid., 132. The establishment of producers' associations was one of the goals of the Knights of Labor. In Its 'Declaration of Principles', article XIX, it is stated: '[We will endeavor to associate our own labors] to establish a co-operative institution, such as will tend to supersede the wage system.' See Wright, 'Historical Sketch', 159.

40 Fones-Wolf, Glass Towns, 137, 141, 220 note 72.

41 Ibid., 140-143. 
and mechanization brought a crisis upon the glass-workers' union and the system of union regulation of labour and production. After 1903 the combination of workers and employers, the so-called dual monopoly, collapsed, prices and production destabilized, rival unions and employers' organizations were disputing the terrain. ${ }^{42}$ Cutters and flatteners left Local Assembly 300 because of the dominant position of the gatherers and blowers. Its influence could be maintained only in hand factories and cooperatives. The reunion of the four crafts in window-glass making in the National Window Glass Workers' Union in 1907 did not change this situation. The union survived by cooperating with companies based on handicraft labour and had to accept wage reductions aimed at keeping the hand plants competitive. ${ }^{43}$

Already in 1898, the mechanized factories had formed a sales cartel of their own, the American Window Glass Company. At that time, it was still relatively easy to establish new window-glass factories, like the producers' associations mentioned above. Therefore, this marketing trust was not able to control the market for window glass completely. At that time, the mechanized companies produced only about 60 per cent of American window glass. The other 40 per cent was more or less equally divided between cooperatives and other non-mechanized factories. These had their own agencies to regulate sales and production: the Federation Window Glass Company for the cooperatives and the Independent Glass Company for other independent producers. As noted above, the National Window Glass Workers' Union, dominated by Belgians, had only restricted influence in these last type of companies. So, the 'dual monopoly' had been broken on the part of both the employers and the workers. Attempts to regulate the market in another way failed. As a consequence, the industry had to cope with overproduction and price and wage dumping. In 1912, the union had to accept a wage reduction of 30 per cent for the craft workers in the non-mechanized factories to keep these alive.

In 1918, all wage differentials between craft and industrial workers in window-glass making had disappeared. ${ }^{44}$ The ruin of the cooperatives after the First World War caused the end of the influence of the craft union. Because of mechanization, much more capital was needed to start a new factory, and the employers no longer needed the trade union to regulate labour 
costs and prevent wage competition in the labour market. ${ }^{45}$ The break-up of the National Window Glass Workers' Union in 1928 'symbolized the demise of the once highly honoured and highly paid craft of window-glass blowing'. ${ }^{46}$ Only in the 1930s, when wage differentials between skilled and less skilled workers had been completely levelled out, did it become possible (in 1933) to establish an industrial union in window-glass making, the Federation of Flat Glass Workers. ${ }^{47}$ The new union was greatly helped by the heritage of labour activism and attachment to trade unionism of former Belgian craftsmen, who were now employed in the mechanized factories as general workers. The Walloon names of the committee members of the Clarksburg branch make this clear: Fernand and Jules Wery, Louis and Phil Malfregeot, Danton Caussin, Amil Gregoire, and Arthur Lorrant. ${ }^{48}$ Tensions remained, however: 'The craft, ethnic, and familial networks that had provided the roots for the earlier growth of cooperatives, labor unions, and socialism in Clarksburg did not adapt easily to the workplace contractualism of the mass-production unions. ${ }^{49}$

At that time, hierarchies in the factories were no longer based on skill, but on management by salaried officials. It meant 'a faster pace, more intense supervision, deteriorating working conditions, and a more authoritarian style of management'. ${ }^{\circ}$ According to the historian of us window-glass manufacturing Ken Fones-Wolf, 'foremen used the fear of unemployment to increase their power to arbitrarily discipline any worker who dared complain about wages or working conditions'. One of the demands of the new industrial union was 'protection from the arbitrary discipline of the foreman'. ${ }^{1}$

\section{Craft unionism in the Belgian window-glass industry}

In Belgium, the window-glass industry was concentrated in Charleroi and surroundings, in places such as Lodelinsart, Jumet, Dampremy, Mariemont, Jemappes, Courcelles, and Gilly. In 1913, 11,255 of the total of 13,095 Belgian window-glass workers were employed in this area..$^{2}$ There are very few

48 Idem, 'Transatlantic Craft Migrations', 314; idem, 'Immigrants, Labor and Capital', 75 .

49 Idem, Glass Towns, 186.

$5^{0}$ Ibid., 30, 184 .

51 Idem, 'From Craft to Industrial Unionism', 39, 45-46.

52 Delaet, 'La méchanisation de la verrerie', 118. 
traces of a movement to establish producers' associations in Belgium that inspired so much enthusiasm among Belgian glass-workers in the United States. As a reaction to the mechanization of the industry, it was decided in 1924 to revitalize the existing (since 1919) Verreries de la Paix based on workers' participation, in which the glass-workers' trade union Nouvelle Union Verrière had invested some money 'to defend the old production process'. This cooperative factory was able to be sustained until 1928.53

Like its American counterpart, the Nouvelle Union Verrière was a typical craft union that excluded low- and unskilled labourers in the glass industry. Because of its 'measures restricting labour supply', socialist leader Émile Vandervelde characterized the union in 1891 as a société de maintien de prix, a society to uphold the price (of labour), comparable to this kind of organization in artisanal workshops. ${ }^{54}$ The union was able to control the organization of the labour process because window-glass making was dependent on the expertise of its members. Skilled glass-workers could not as easily be replaced as general labourers or auxiliary workers. As long as the union was able to control entry into the trade and in this way regulate labour supply, it could maintain a powerful position in industrial relations. Whenever industrial conflicts arose, these were on issues related to the control of the supply of labour.

Like the name itself indicates, the Nouvelle Union Verrière was the successor to a Union Verrière, established in 1883. According to Vandervelde, this union aimed to keep wages up by limiting labour supply, firstly by admitting only fully qualified blowers, gatherers, cutters, and flatteners to the factories, secondly by union control of the number of apprentices, and thirdly by carefully screening new members. ${ }^{55}$ In this way, the union continued an older artisanal tradition to accept only family members as apprentices (ouvriers $d u$ sang). ${ }^{6}$ The establishment in 1883 of the Union Verrière was a reaction to attempts by employers to admit more apprentices and abolish other restrictions to the supply of labour.

In 1884, the union became involved in a showdown for the first time when it tried to install a system of travail à deux pour un (two working for

Ibid., 144-145, 147; Lefèbvre, La verrerie à vitres, 143.

54 Vandervelde, Enquête sur les associations, Tome 1, 114. Elsewhere he described the Union Verrière somewhat differently: 'pour ainsi dire le trait d'union entre les société de maintien de prix et les syndicats affiliés au Parti Ouvrier' ['so to say, in between societies to uphold the price of labour and trade unions affiliated to the Workers' Party']: ibid., Tome 2, 41.

55 Ibid., Tome 1, 114-115.

56 Ibid., 118; see also Delaet, 'La méchanisation de la verrerie', 126; Lefèbvre, La verrerie à vitres, $60-61$. 
Figure 4.3 Banner of L'Union Verrière Belge, 1894

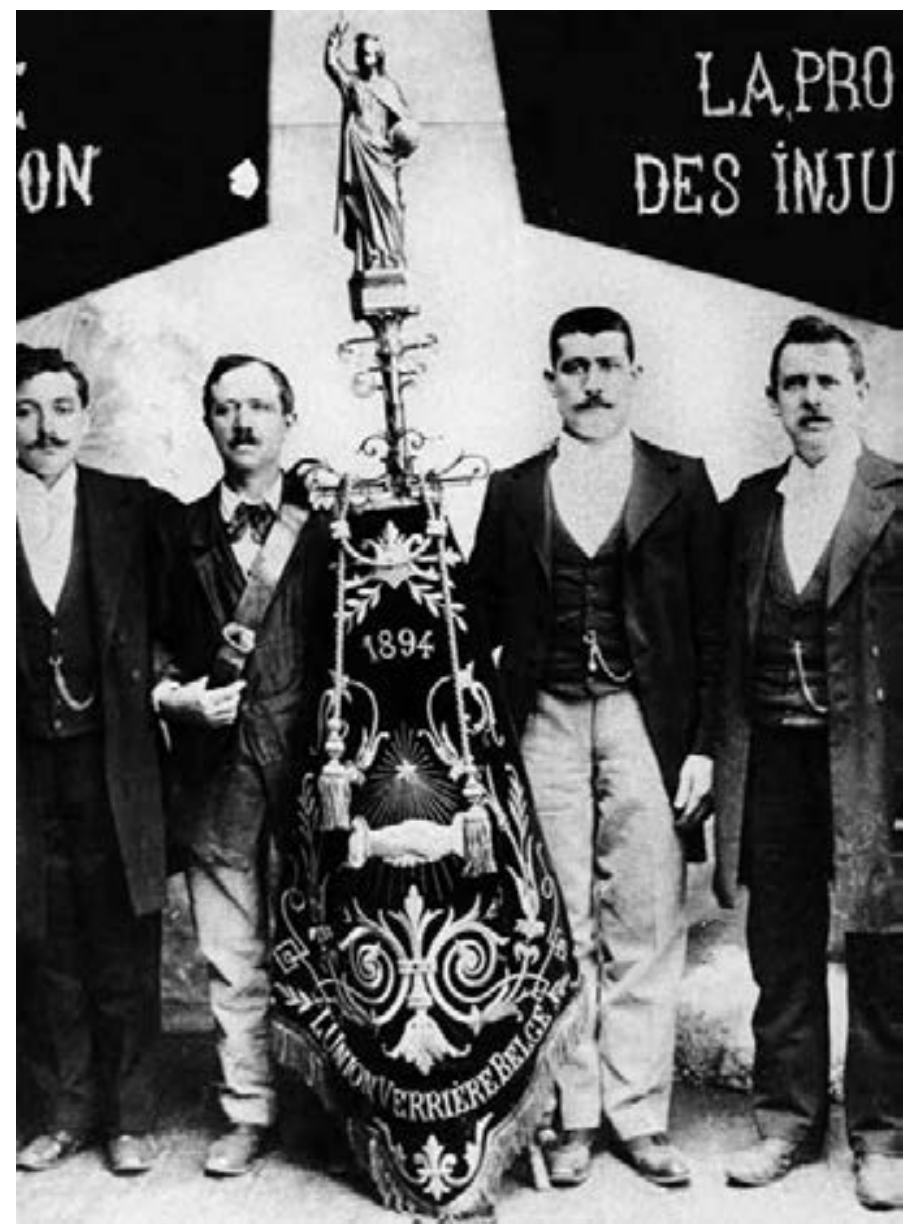

Collection Musée du Verre de Charleroi. Used with permission

one) to combat unemployment. It was because of this strike that 600-700 Charleroi glass-blowers migrated to the United States, invited by Local Assembly 300 in Pittsburgh (as mentioned above). Emigration was part of the union's strategy to regulate labour supply, as becomes clear from the fact that the union had at its disposal a resistance fund (caisse de résistance) that paid allowances not only in case of strikes, but also in case of unemployment and emigration, without separating the administration of these services. 57 
Figure 4.4 Glass-blowers and -cutters on strike, date unknown

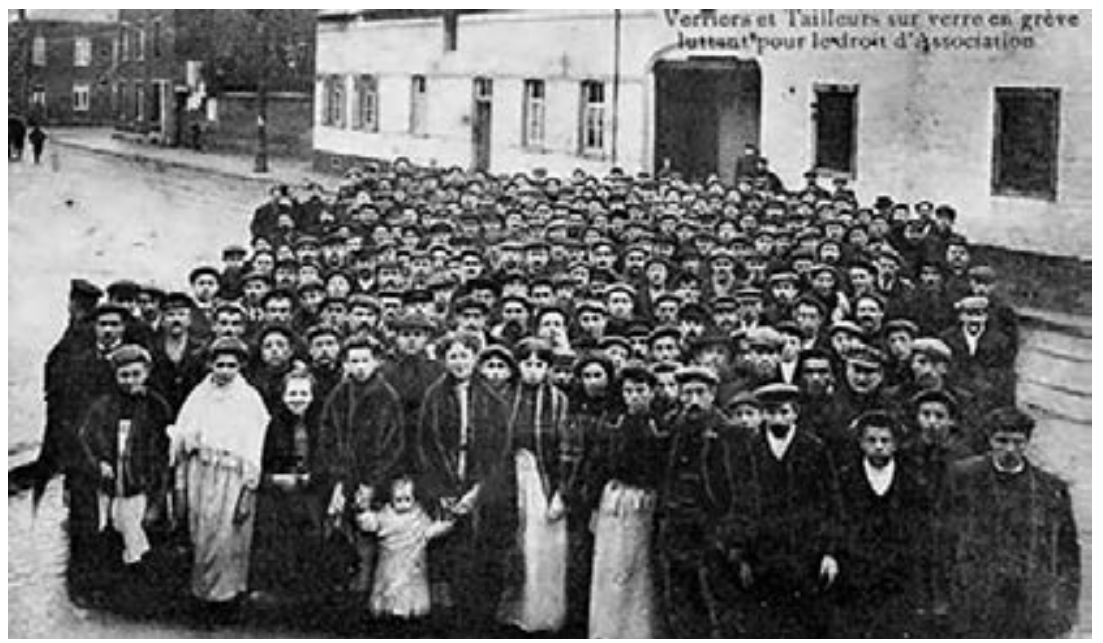

Collection Musée du Verre de Charleroi. Used with permission

During the strike, a conflict arose between the glass-blowers and other workers, both craftsmen and labourers, demanding a pay rise at the cost of the glass-blowers. ${ }^{5}$ So it seems that there was a kind of collective wage bill. Elsewhere it is mentioned that glass-blowers did not have to pay for a second gatherer anymore. These are indications that in the $1880 \mathrm{~s}$ the glass-blowers were no longer internal contractors. ${ }^{59}$ After the strike, the conflict between the different crafts subsided: they continued to be organized in the Union Verrière. Nevertheless, as in the United States there were huge differences between different kinds of workers, with the glass-blowers at the top end of the hierarchy. They were 'a labour aristocracy, a better-paid and looked-upon class'. ${ }^{60}$ The Union Verrière was dominated by workers skilled 'on warm glass' (blowers, gatherers, and flatteners). Their interests diverged from those of workers 'on cold glass', who were involved in the cutting, transport, and storage of the glass. The last group, called magasiniers (warehousemen), were the equivalent of the American 'snappers'. It is significant that glass-blowers were paid by the piece, cutters by the day. ${ }^{61}$ Originally, like in the United States, cutters were members of

$5^{8}$ Ibid., 124.

59 De Ridder, 'Loonsystemen', 111.

60 Delaet, 'La méchanisation de la verrerie', 126.

61 Ibid., 125; De Ridder, 'Loonsystemen', 118. 
the Union Verrière and its successor, the Nouvelle Union Verrière. When, after a strike in 1895 , the union accepted a wage reduction for the cutters, while, in contrast, wages of blowers and gatherers were raised, the cutters left the Nouvelle Union Verrière and joined the recently established (189o) Syndicat des Magasiniers Verriers. ${ }^{62}$

At first the Nouvelle Union Verrière had aspired to unite all workers including those 'on cold glass', perhaps under socialist influence, ${ }^{6}{ }^{6}$ but the solidarity of the workers 'on warm glass' did not last. ${ }^{64}$ As long as the industry was dominated by craftsmen, conflicts kept arising with the Syndicat des Magasiniers Verriers, reminiscent of the conflicts between the American National Window Glass Workers and the snappers. The craft identity of the blowers was expressed in a telling statement by the president of Nouvelle Union Verrière, Edmond Gilles, in 1920:

A strike of cutters and warehousemen? I do not know of any. [...] They have been fooling about for 25 years. There are at least fifteen occupations in glass-making, but there is only one that really produces: the blowing of the glass cylinders. The others, who are only helpers, want to earn as much as the blowers. This will not be the case as long I am in the Union Verrière. ${ }^{65}$

\section{Regulatory unionism}

Mechanization in the Belgian window-glass industry proceeded much slower than in the American factories. For this reason, the Nouvelle Union Verrière was able to continue the protection of craft workers in regular companies much longer than its counterpart in the United States. It did not have to seek refuge in workers' cooperatives, as the us craft union did. Charleroi factories had been the first to introduce the continuous tank in the 1880 s - in the United States this occurred only in the 189os, following the Belgian example - but machines to blow glass cylinders or produce flat glass directly were introduced in Charleroi at a much later date. The first and for several years only mechanical flat-glass factory opened in 1914 in Dampremy; a genuine 'industrial revolution' in Belgian window-glass

62 Ibid., 120; Lefèbvre, La verrerie à Vitres, 85-86.

63 In 1894, the secretary of the Nouvelle Union Verrière, Joseph Lambillotte, became a Parti Ouvrier Belge member of parliament: De Ridder, 'Loonsystemen', 123.

64 Ibid., 119; Lefèbvre, La verrerie à Vitres, 85-86.

65 Cited by Delaet, 'La méchanisation de la verrerie', 134. 
manufacturing occurred only in the second half of the 1920s. The Belgian industry managed to find new markets in this period, but was completely cut off from the once important American market, where window glass was produced much more cheaply, thanks to advanced mechanization: between 1905 and 1913 the share of exports to the United States diminished from 30 to 4 per cent. ${ }^{66}$ Slow mechanization implied that capital needs to invest in a new factory in the Charleroi district were still relatively modest, even after the introduction of the continuous tank in the 1880s. Easy access of new companies to the trade caused economic instability, overproduction, and the subsequent closure of plants, to resume production only during economic recovery. In the first decade of the twentieth century crises of overproduction occurred in 1901-1902, 1904, and 1908. ${ }^{67}$ To support wage levels, the Nouvelle Union Verrière took up a struggle to control the supply of craft workers in this period. The union's first concern was to be recognized as a contract partner and to be allowed to apply the traditional system to divide work in bad times (travail à deux pour un) in order to prevent competition among workers. In defence of this customary right, it organized strikes in 1900-1901 and 1905.

Periodic emigration was another device to regulate labour supply, not only to the United States, but also to centres of window-glass manufacturing in other countries. ${ }^{68}$ The individualistically minded glass manufacturers (maitres-verriers) each had their own sales agent - most of them in London - and through these intermediaries every change in the market was directly converted into fluctuating orders and prices. There was no cooperation to regulate production and sales collectively according to demand. ${ }^{69}$ Severe competition among manufacturers enabled sales agents to adapt prices to their advantage, and these were directly translated into wage setting. To prevent wage fluctuations, it was in the interest of craft workers to achieve a more stable market for finished goods. In fact, only their union, the Nouvelle Union Verrière, had enough collective power to regulate the market. To prevent overproduction crises being passed on to wage levels, from 1909 onwards the union began to put pressure on the employers to establish a common sales office and to regulate production accordingly. By price agreements, it was thought, employers would also be able to come to terms with the union on the

66 Ibid., 113-116, 120-121; Lefèbvre, La verrerie à Vitres, 74.

67 Ibid., 70-71, 81; Delaet, 'La méchanisation de la verrerie', 129.

68 De Ridder, 'Loonsystemen', 182-197.

69 Delaet, 'La méchanisation de la verrerie', 122-123; Lefèbvre, La verrerie à Vitres, 80-81. 
regulation of wages. In spite of fierce resistance from the sales agents and individual employers, the union - in particular its president Edmond Gilles - succeeded in convincing the employers to establish a collective sales office. Gilles threatened to demand extra wage rises and a boycott of firms that refused to join.

The Mutuelle des Maîtres-Verriers was established in 1911. As a sales office, it regulated production according to demand and cooperated with the Nouvelle Union Verrière to distribute available manpower over existing companies. They were also able to conclude collective agreements. Part of the deal was that companies would employ only union members, and that apprentices would be engaged only with union permission, depending on demand in the labour market. In this way, the union would be able to control labour supply. Part of the cooperation was that wage reductions were accepted by the union, but as soon as companies engaged non-union men, or tried to undermine the traditional proportion between craft workers and others, the union took action. This was the case in 1919 in a five-month strike, won by the union..$^{70}$

After the turn of the century, the 'dual monopoly' of the glass-workers' union and the employers' organization in the United States had fallen apart, as described above, and the craft union survived there only in producers' associations. At that time, however, Belgian craft workers were still able to consolidate their position in the labour market and the flat-glass industry by cooperating with the employers in a characteristic form of 'regulatory unionism'. Their position of influence, based on the survival of traditional methods of production around the specialized glass-blower, was sustained until 1924. Slowly, mechanical glass-blowing gained ground also in Belgium, with machines based on the Libbey-Owens process that were already prevalent in the United States. Around 1930, 9o per cent of window glass made in Belgium was produced mechanically. In 1927, the owners of mechanized factories established their own sales cartel, called the Union des Verreries Mécaniques Belges since 1930. It was dominated by large investors, like the Société Générale and the Banque de Bruxelles. The role of the Nouvelle Union Verrière in the regulation of the market was now over: Belgian big business did not care about regional issues or the interests of specific groups of craft workers. ${ }^{71}$

70 Ibid., 82; De Ridder, 'Loonsystemen', 198-203; Delaet, 'La méchanisation de la verrerie', 130-134.

71 Ibid., 135-142, 150; Lefèbvre, La verrerie à vitres, 102-122. 


\section{The arduous road to industrial unionism}

In 1891, socialist leader Émile Vandervelde thought that the exclusive hold of the specialized glass-workers on the industry would inevitably come to an end, because mechanization would equalize the existing differences in skill at a much lower level: 'In this way, in glass-making, as anywhere else, the logical outcome, inevitably, is the automated industry; manual skills will be reduced to nothing, and it will become impossible to defend a corporate monopoly.72 Vandervelde's forecast had indeed come true in the mechanized sector of the American window-glass industry. But because skilled workers had been able to create a way out for themselves in the producers' associations, it was not until the 1930 s that the glass-workers' union could be transformed into a general industrial union, uniting all workers in the industry.

In the Belgian window-glass industry deskilling because of mechanization, as predicted by Vandervelde, was delayed. Because of their exclusive skills, craft workers in the window-glass industry, especially the glassblowers, remained a powerful force in industrial relations, and in the labour market, until in the late 1920 s mechanization definitely overtook the hand plants. Just like in the United States, mechanization caused the number of former auxiliary workers to grow, both magasiniers and other workers 'on cold glass': in the mechanized factories they were more than half of total staff. ${ }^{73}$ Because since the late 1920s, specialists 'on warm glass' had tended to become more and more superfluous, they were obliged to apply as hommes à machine for work in the mechanized factories on the same footing as the magasiniers. This was not a smooth or easy transition; one observer noted in 1933:

The glass-workers, once so proud of their professional qualities and so conscious of the superior status they occupied and had achieved for so many years: among them the degradation is substantial. The majority of them have had to adapt to another life style, and suffer intensely. ${ }^{74}$

Another, Virgile Lefèbvre, wrote in 1938:

the social situation of the old specialists on warm glass has been profoundly and irreversibly upset. These men, who barely ten years ago were 
privileged in earning large remunerations and were spending generously, have now become proletarians in every sense of the term. ${ }^{75}$

But by no means all former craft workers were ready to become ordinary labourers: in 1936 only 1,550 of the 6,00o glass-workers who in 1921 had been members of the Nouvelle Union Verrière were employed in the mechanized factories. The others had ended up in other industries $\left(1,75^{0}\right)$, were unemployed (400), had retired $(1,378)$, or had died $(512) \cdot{ }^{6}$ In 1925 a national federation of glass-workers had been formed, the Fédération Nationale des Travailleurs du Verre. It combined several trade unions in the mechanized window-glass factories, like the Syndicat des Magasiniers-Verriers and the Syndicat des Verreries Mécaniques (established in 1924). The last one organized newly recruited workers in the mechanized window-glass factories, among whom were also former members of the Nouvelle Union Verrière, which at that time still excluded workers in those factories. The Nouvelle Union Verrière continued its existence primarily because of pension rights attached to the union fund. In 1928, it hesitantly started to cooperate with the Fédération des Travailleurs du Verre. In 1930, this cooperation was institutionalized in a permanent committee that adhered to the Intersyndicale du Bassin de Charleroi, but not to the Parti Ouvrier Belge. ${ }^{77}$

\section{Subcontracting and craft unionism in the Amsterdam diamond industry}

Like the window-glass industry in Belgium, diamond processing was concentrated in one locality: Amsterdam. ${ }^{7}$ Other similarities were a focus on export, highly skilled labour, and periodic migration to other centres of the trade. Like window-glass making in Charleroi, diamond processing could be maintained in Amsterdam because a relatively closed group of skilled workers transmitted the secrets of the trade to their children and other kin. Diamond processing is another example of an industry organized on the basis of internal subcontracting, originating from independent artisanal labour. At the beginning of the nineteenth century (the industry had been

77 Ibid., 147-149 and 151-152; Delaet, 'La méchanisation de la verrerie', 147-148.

78 The next sections are based on Van Tijn, 'Geschiedenis van de Amsterdamse diamanthandel en -nijverheid'. 
located in Amsterdam long before that date), jewellers put out work at piece rates to various craftsmen (splitters, cutters, and polishers), who did their job at home or in workshops owned by the jewellers. Polishers also rented seats at grinding mills in specially furnished attics. From the 1820 s, jewellers started to erect polishing factories themselves, where grinding mills were powered at first by horses, and after 1840 by steam power. Master polishers rented accommodation in these factories and brought their own instruments. They subcontracted work for piece rates from the jewellers, and in their turn employed helpers themselves, like fixers (who put the diamonds to be polished in the right position), apprentices, and messenger boys. Helpers worked for time wages, as was common in subcontracting in other industries as well. As independent craftsmen, polishers were allowed to rent grinding capacity at factories of different jewellers.

In 1866, master polishers established a Diamantslijpers-Vereeniging, a typical craft union, to defend their interests on various fronts. Its aim was to negotiate low prices for a place at the grinding mills with the factory owners, high tariffs for its members with the jewellers, low wages for their fixers and other helpers, and lucrative contracts with apprentices or their parents. The artisanal outlook of this Diamantslijpers-Vereeniging is apparent from the establishment in 1873 of its own diamond factory, the Amsterdamsche Diamantslijperij, financed by the union and accessible only to its members. There is a clear analogy with the producers' associations of the window-glass workers. This concerned brilliant polishers. The so-called rosette polishers, another specialism, established their own factory as well, and on the same conditions.

In those years (1871-1873), diamond processing was revolutionized by the enormous amount of raw diamonds brought to Amsterdam from the newly discovered diamond fields in South Africa. In this so-called Kaapse Tijd ('Times of the Cape [of Good Hope]'), several new craft unions emerged of other specialists in the diamond trade, next to the older brilliant polishers' union: rosette polishers', brilliant cutters', splitters', and fixers' unions. Each of these tried to control labour supply in their own craft by regulating apprenticeship. In this exceptional period of high labour demand, they could easily negotiate higher wages or tariffs for subcontracted work. In 1872 , fixers, who were paid by the polishers, organized a strike against their masters. However, after the economic downturn late in 1873, these unions were not able to resist downward pressure on wages. In the 1880 s, they had all disappeared. As a consequence, apprentices were now taken on board without any restriction, resulting in an abundant supply of diamond workers. 
Figure 4.5 The main operations of diamond processing: splitting, cutting, polishing, C. 1880

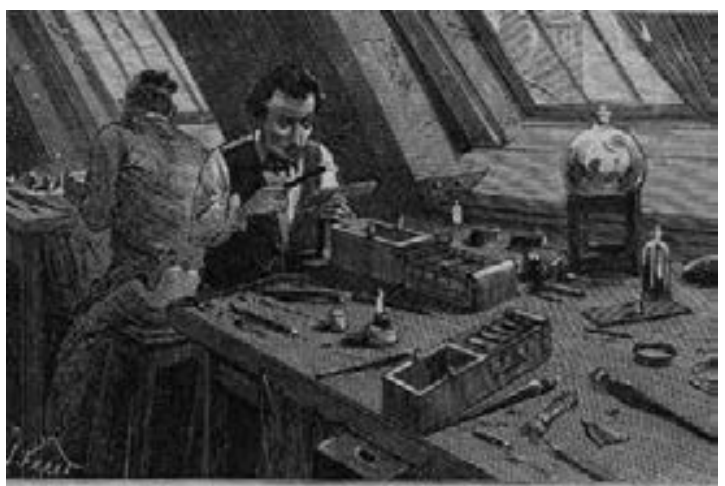

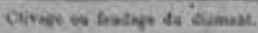

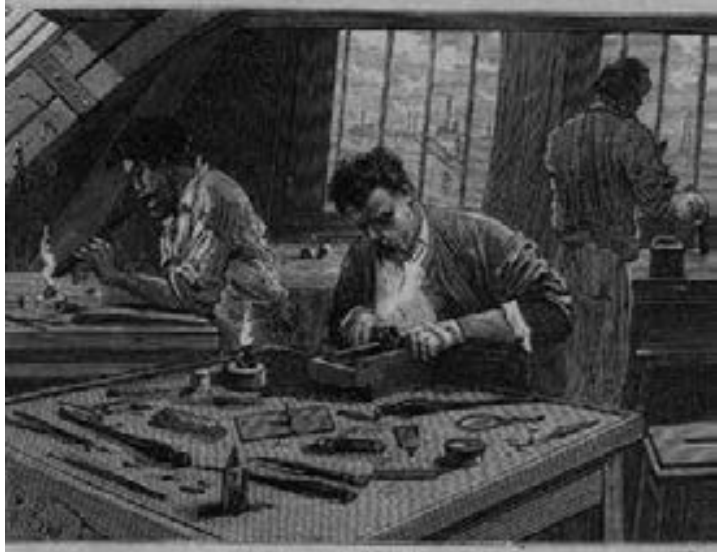

Brulleseres Gille da dinmes.

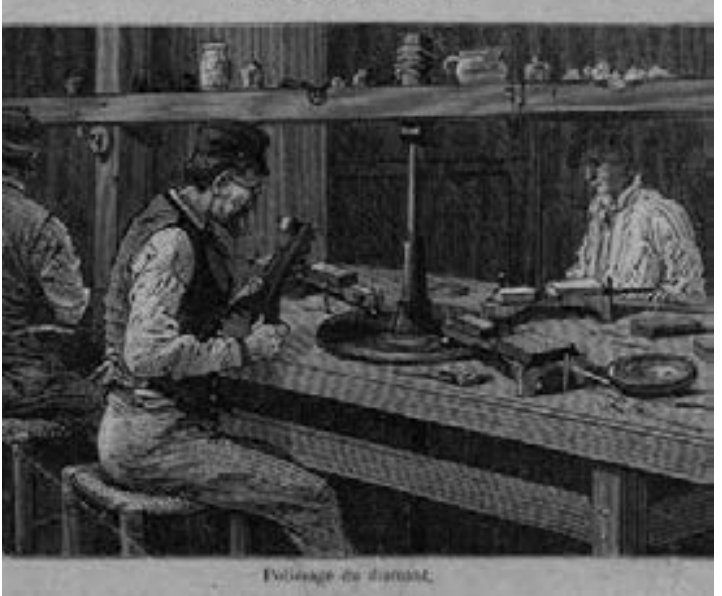

Collection City Archives Amsterdam 


\section{Growth and restructuring in the 1880 os}

During and after the Kaapse Tijd, the number of diamond workers expanded enormously from about 1,400 in the 186 os to 10,502 at the census of 1889 . Growth was associated with the rise of a new type of jeweller, originating from the master polishers, who started to work independently from the old class of jeweller. They bought small amounts of raw diamonds, polished these themselves, and sold them again in polished state. These developments show that entry to the trade was relatively easy. Some became big jewellers, but in general, from that period, the diamond trade was dominated by small jewellers and petty traders without much capital, who were not able to hold stock for a longer period, and glutted the market with their finished products. Their number can be estimated at about 1,00o.

In fact, these small trader-polishers operated as middlemen between wholesale merchants in raw diamonds, located in London, and those in finished products, at that time mainly in Paris, who cashed the real profits. Because of severe competition and easy entry of polisher-jewellers, supply and prices on the supply side in the Amsterdam trade were completely dependent on the London wholesale trade in raw diamonds, all the more so since in 1888 supplies from South Africa were monopolized by the London De Beers Company (owned by Cecil Rhodes). On the sales side, prices of finished diamonds were dictated by large merchants as well. They were able to set purchasing prices and put pressure on wages in this way. Intense competition between small traders and polisher-jewellers caused profits and wages earned in Amsterdam to be squeezed between market pressures on the raw and the finished side. Attempts to organize the Amsterdam traders to collectively regulate both the purchase and sales markets failed.

One of the consequences was that in the 188 os several jewellers lost their independent status as middlemen, and from then on only exploited factories on behalf of foreign merchants. Master polishers subcontracting work from this type of factory owner became dependent on this one employer, although formally they were still independent craftsmen renting grinding capacity at the employer's premises. In the 189os, this tendency was reinforced: jewellers obliged their personnel to work at their factories under the supervision of a foreman, and therefore no longer as subcontractors. It appears that in this period the system of internal subcontracting was gradually replaced by a system of direct employment.

Changing demand in the world market also caused the rise of a new specialty in Amsterdam of processing very small diamonds from small pieces of raw stones and flakes (called 'chips'). Amsterdam concentrated more and 
more on the processing of these small stones, while larger stones increasingly went to the upcoming industry in Antwerp. ${ }^{79}$ Large stones were a specialty of Jews, while small ones were mostly processed by non-Jewish, commonly called 'Christian', diamond workers. Because of the growth of this segment, their number grew considerably in the 1880 s, resulting in a more or less even number of Christian and Jewish polishers at the end of that decade. At that time there were in fact two separate diamond industries in Amsterdam, producing for separate markets, whose workforces consisted of different ethnic-religious groups, living and working in different parts of the city.

\section{From craft to industrial unionism}

From the end of the 188 os, new trade unions emerged in the diamond industry, like in 1894 the Briljantslijpersknechts-Vereeniging 'Streven Naar Verbetering' ('Aspire to Improve'), an association of journeymen polishers in the 'Christian' branch of the trade. It did not join the more general Nederlandsche Diamantbewerkers-Vereeniging (Dutch Diamond Workers' Union), established some years earlier, because masters were also admitted to the latter union. Apparently, the interests of (subcontracting) masters and journeymen (hired by them) were not perceived as equal. In 1894, strikes were organized by this journeymen's association, directed against their bosses and polisher-traders in 'Christian' factories. The Nederlandsche Diamantbewerkers-Vereeniging had been established in 1889 by both Jewish and Christian diamond workers. The union was led by young social democrats, who within a few years would play an important role in the Amsterdam diamond workers' movement, and later also in the Dutch trade union movement as a whole. At first, however, they were not able to unite a stable and substantial following. Apart from this attempt at general union, there was a small craft union of male and female brilliant cutters (Briljantsnijdsters- en -Snijders-Vereeniging, established 1894), and an 'international' fixers' union (Internationale Verstellers-Vereeniging, also from 1894). Like the journeymen's association Streven Naar Verbetering, this 'international' union refused to join the polishers in one union, because they were paid by them.

These differences did not hamper solidarity and common action, however, when unexpectedly in November 1894 a spontaneous strike united all 
categories of workers in the diamond industry. ${ }^{80}$ At a mass meeting, a strike committee was formed of representatives of the different unions mentioned above. Within a few days, the employers gave in and accorded a general minimum tariff. In spite of the many contrasting positions, like those of polishers and fixers, and masters and journeymen, it was decided to form a general committee of all diamond workers' unions (Hoofd-Comité der gezamenlijke Diamantbewerkers-Vereenigingen), which soon developed into a general diamond workers' union (Algemene Nederlandsche Diamantbewerkersbond, ANDB), one of the most successful and influential trade unions in Dutch trade union history. In 1906, it had a decisive influence in the formation of the Dutch trade union federation (Nederlandsch Verbond van Vakverenigingen, NVV). The board of the diamond union was dominated by the social democrats, who at an earlier stage had founded the Nederlandsche Diamantbewerkers-Vereeniging (see above), and was presided over by Henri Polak, later to become president of the Nvv. ${ }^{81}$

Although the 'Christian' journeymen polishers had initiated the movement with a strike against their masters, the newly established diamond workers' union was led by an elite of master brilliant polishers and cutters. They succeeded in establishing themselves as representatives of labour in the diamond industry as a whole, thereby overcoming (potential) conflicts between different occupational categories and between workers of different religious denominations. Looking back in 1898, Polak remarked:

Jewish and Christian diamond workers used to be strangers, but have learned to know each other and are now united as brothers. Also, the relationship between masters, journeymen, and fixers has much improved. Among us there is no difference of status anymore. We are all just diamond workers and co-workers. ${ }^{82}$

The new union still had to cope with conflicts of interest between different kinds of workers, but the restructuring of the industry, oversupply in the labour market, and pressure on wages had more or less equalized working conditions in all categories. A tendency towards proletarianization becomes apparent in the reorganization of the labour process in several factories, mentioned above, where work was no long subcontracted. Yet in 1894 there

80 The direct cause was a strike of journeymen in a 'chips' factory, because their work was reorganized and would from now be directed by a foreman: Van der Velde, De ANDB, 46-48.

81 Cf. Bloemgarten, Henri Polak.

82 Cited ibid., 109. 
were still about 850 master brilliant polishers, as against about 3,300 journeymen. At first, some of the initiators of the union thought that cooperation between masters and journeymen would not be possible, and that separate unions should be formed, but in the end it was concluded that wages in every category were dependent on tariffs negotiated with the jewellers, and that these would only profit from rivalry between different groups of workers. ${ }^{83}$ To protect wage standards of both masters and journeymen, it was deemed necessary to agree upon a general minimum tariff. This could be achieved only if all diamond workers united in a general sales cartel of their labour power.

\section{Regulatory unionism}

The need for all diamond workers to unite and to force the employers to comply with a minimum tariff was closely related to the weak market position of the Amsterdam jewelers between the wholesale traders in raw diamonds and those in finished products. A general minimum wage tariff could limit the squeeze of both prices and wages by forcing the Amsterdam jewellers to set minimum prices in the markets, something they were not able to achieve on their own. The diamond workers' union itself was quite well aware of this position and consciously played the game of business unionism, secretly supported by the big jewellers, who had the same interests of regulating market prices and preventing small traders from corrupting prices by wage competition. To resist the monopoly in the supply of raw diamonds by De Beers and the dominant position of large merchants in the market of finished diamonds, an Amsterdam monopoly had to be formed, as the historian of the Amsterdam diamond industry, Theo van Tijn, remarked:

In principle, this could have been achieved by a combination of diamond traders, for instance by means of an office to centralize purchases and sales that could have dictated conditions to the wholesale merchants in raw and in finished diamonds. But this was inconceivable in the Amsterdam situation [...]. However, the same goal could be achieved by a monopoly of labour, a cartel that organized the sale of labour power collectively. And this was the outcome of the strike of $1894 .{ }^{84}$

84 Van Tijn, 'Geschiedenis van de Amsterdamse diamanthandel en -nijverheid', 187. 
From then on, the Amsterdam wage tariff became the standard for establishing the prices on markets the Amsterdam industry produced for, mainly in the United States. The character of diamonds as luxury products made this possible: a wage rise could easily be incorporated into the price, provided there was a power (i.e., the trade union) to enforce this. On this basis, the union could arrange wages with employers in a kind of regulatory unionism. For the (big) jewellers a fixed wage tariff, provided it was generally applied, was important to prevent wage competition and undercutting by the many small traders in Amsterdam. Several jewellers understood that a generally applied wage standard could be an effective instrument to stop downward pressure on prices. But this silent compliance in itself was not enough to enforce the minimum tariff; therefore, the union had to threaten or stage strikes regularly. ${ }^{85}$

The diamond workers' union could influence wages and prices as long as these were determined in Amsterdam. As noted before, the only factor in the location of the industry there was the availability of skilled labour. The union tried to regulate supply by limiting the number of apprentices. But skilled labour and training capacity were also available elsewhere, more specifically in Antwerp. There was regular movement of diamond workers between Amsterdam and Antwerp. To prevent wage competition by the Antwerp diamond industry, the Amsterdam union stimulated and supported the foundation of a union in Antwerp. The aim was to set the Amsterdam tariff in Antwerp as well, and to regulate wages and labour markets internationally. Also, transnational insurance schemes were agreed upon. ${ }^{86}$ These endeavours were only partially successful, however. The Belgian jewellers had no intention of following the example of their Amsterdam counterparts. Small Antwerp employers tended to move the industry more and more to the Campine countryside, in the backyard of Antwerp, so to say, where in the villages an 'outside' cottage industry emerged. Labour was much cheaper there, and union control was impossible. Already in 1908, employment in the Antwerp diamond industry was as large as in Amsterdam. After the First World War, the Amsterdam industry was hit by a structural crisis. In 1929 there were only 6,ooo diamond workers left, while in Belgium their numbers were estimated at 25,000. In these circumstances, the Amsterdam diamond workers' union had to accept wage cuts. The attempts to defend the Amsterdam industry by regulating wages internationally had failed. In

85 Ibid., 190-194; idem, 'De Algemeene Nederlandsche Diamantbewerkers Bond', 410-414; Bloemgarten, Henri Polak, 404, 608.

86 Cf. Hoogenboom, 'Transnational Unemployment Insurance', 265-270. 
1940, there were only 4,00o diamond workers in Amsterdam, most of them unemployed. Many were deported by the Nazis during German occupation and died in concentration camps. ${ }^{87}$

\section{Conclusion}

The origin of the labour process in these industries from independent artisanal work and the importance of internal subcontracting were reflected in conflicts between different categories of workers, between subcontractors and their helpers or journeymen, and between groups of workers originating from these categories, such as glass-blowers and 'snappers', or diamond polishers and fixers. They had often organized in different unions. However, away from these original divisions, a transition from 'craft' to 'industrial unionism' can be recognized in all three cases, but in a very different way.

In the Amsterdam diamond industry, the legacy of internal subcontracting seemed to be very much alive in the period before the emergence of a general union in the 189os. At first, workers tended to organize on the basis of their craft, and on their position as masters or journeymen within these crafts. Nevertheless, in a decisive turn during the strike of 1894, it proved to be possible to unite all these shades of dependency into one union that included all workers in the diamond industry, and to overcome former social and cultural differences and hierarchies. The existing craft unions were able to overcome their differences and to establish a general union, the Algemeene Nederlandsche Diamantbewerkersbond. The emergence of this general union can be explained by changes in the labour process in diamond manufacturing preceding the 1894 strike that tended to generalize market dependencies to all workers, regardless of their apparent differences. Jewellers had changed roles from merchants to factory owners and had obliged formerly independent subcontracting craftsmen and their personnel to work exclusively at their premises under supervision of a foreman. Although formally still considered 'masters' and 'journeymen', both groups were now directly employed and subordinated by the owners as factory workers. From this perspective the new union, seemingly uniting various craft unions, can in fact be considered truly industrial in its own way.

The changes in the organization of the labour process in the diamond industry were only institutional, however. The technology of cutting, grinding, and polishing remained basically the same. In this respect, 
there were huge differences with window-glass making, both in Belgium and in the United States. Although hard to trace exactly, the demise of subcontracting was surely on its way in these industries in the $189 \mathrm{os}$, but relationships between craftsmen around the central figures of the glass-blowers on the one hand and their former underlings on the other remained tense until the very end. In window glass, the semi-independent position of the blower and his fellow craftsmen was not simply undermined by a change in workplace organization (as in the Amsterdam diamond industry), but foremost by technological change. The demise of subcontracting in window-glass making was inextricably linked to the demise of craftsmanship itself. Mechanization caused the highly skilled crafts of 'gathering', 'blowing', and 'flattening' to become superfluous. As a consequence of mechanization, craftsmen had to cooperate with former underlings on an equal footing - if they were prepared to work in the mechanized factories at all.

While in Belgium slow mechanization delayed the disappearance of the crafts and enabled the craft union Nouvelle Union Verrière to survive in the industry as a whole until the 1920s, in the United States in the first decades of the twentieth century craft workers had to separate themselves from the labour market for the mechanized factories by establishing their own producers' associations. Most of the workers in these cooperative efforts were immigrants from the Belgian centre of window-glass making around Charleroi, where at that time the crafts were still very much alive. From Charleroi they continued a craft tradition in the Window Glass Workers of America Local Assembly 30o, which through the international endeavours of the Knights of Labor had established close contacts with its Belgian counterpart already in the 1880 s, and with its successor (from 1907), the National Glass Workers' Union.

These skilled immigrants also brought a specific kind of 'associational' socialism from Belgium, belonging to what several authors have identified as the 'artisanal phase' of the labour movement. In the United States, this 'artisanal' socialism of the craft workers disappeared with the demise of the producers' associations during and just after the First World War. The Belgian union, although strongly influenced by socialist leaders such as Internationalist Albert Delwarte in the beginning, later distanced itself from the socialist movement in a self-chosen exclusiveness, and never affiliated to the Belgian Workers' Party. The Amsterdam diamond workers' union, by contrast, became one of the pillars of the Dutch socialist movement. According to its historian, Theo van Tijn, the outspoken socialist ideology of its leaders - in its Marxist, not its 'artisanal' variant - was one 
of the factors promoting unity among the diamond workers. ${ }^{88}$ They had learned to interpret class relations between workers and employers as more fundamental than between different groups of workers, and acted accordingly. It is also possible to turn this reasoning upside down, however; diamond workers were receptive of this idea, because more and more equal working conditions made them feel united. In this respect, there were huge differences with the Belgian and the American-Belgian unions of skilled glass-workers. In window-glass making, it proved impossible to overcome divergences in skill and hierarchy. Separate trade unions continued their existence until the disappearance of the skilled workers. The sectionalism of the skilled glass-workers could be overcome only in the 1930s, when their role was finished completely. Only then could a form of 'industrial unionism' emerge, including all workers in the window-glass industry.

In all three industries, trade unions had the biggest impact when they were able to regulate product markets and industrial competition through labour market control. This was the case in the American window-glass industry in the 'dual monopoly' of the Window Glass Workers of America and the American Window Glass Manufacturers Association in the $1880 \mathrm{os}$ and 189os; in the Belgian window-glass industry with the general sales office established by the employers around 1910 under pressure from the Nouvelle Union Verrière; and also with the general wage tariff enforced by the Algemeene Nederlandsche Diamantbewerkers Bond in 1894, with the support in principle of the big jewellers. In all of these cases, trade union action caused a stabilization of sales markets and sales prices, partly because entry by newcomers competing on lower prices and wages was limited. These were clear cases of what in the American literature has been called 'regulatory unionism'. In each case, trade unions were able to influence markets in specific circumstances, and only in the short or medium term. After 1900, the 'dual monopoly' in the United States collapsed because of the rise of mechanized factories; in Belgium this happened in the second half of the 1920s. In the Amsterdam diamond industry, the influence of the diamond workers' union in the labour market was lost after the First World War because of fierce competition from Antwerp.

Labour market control by the trade unions concerned was achieved by different means. In window-glass manufacturing, it was realized by limiting entry to the skilled crafts, excluding half- or semi-skilled workers, like snappers or magasiniers. The crisis in labour regulation was caused by the demise of the skilled glass-worker because of mechanization. These cases 
of regulatory unionism had been based on traditional craft unionism, both in Belgium and in the United States. In the Amsterdam diamond industry, none of the categories of workers (master and journeymen polishers, fixers, splitters and cutters) was able to control its own labour market. Market regulation could be achieved only by uniting all workers, regardless of skill or craft. 


\title{
5 From placement control to control of the unemployed
}

\author{
Trade unions and labour market intermediation in western \\ Europe in the nineteenth and early twentieth centuries*
}

\begin{abstract}
This chapter focuses on the changing role of trade unions in organizing labour intermediation in several European countries around 1900 (Germany, Austria, France, Great Britain, the Netherlands, Belgium, and the Scandinavian countries). From the end of the nineteenth century trade union intermediation was incorporated in government-led labour exchanges, be it locally or nationally. In this process intermediation was transformed from an instrument of wage control by trade unions into an instrument of control of the unemployed by public exchanges. Originally, trade unions had claimed a monopoly on the organization of intermediation to prevent oversupply in the labour market and downward pressure on wages. However, a trade union monopoly on labour exchange was never realized anywhere. Trade unions therefore had to employ another method to prevent a decline in wages in bad times: unemployment insurance. In the end, the moral hazard associated with this type of insurance forced unions to cooperate with employers and authorities to control the unemployed. Those out of work were now required to register at public labour exchanges to confirm their willingness to work. In this way the labour supply was in effect split into 'fit' and 'unfit' workers.
\end{abstract}

Keywords: labour market intermediation, labour market control, public labour exchanges, Bourse du Travail, unemployment insurance, Beveridge

* Reprinted from Ad Knotter, 'From Placement Control to Control of the Unemployed: Trade Unions and Labour Market Intermediation in Western Europe in the Nineteenth and Early Twentieth Centuries', in Sigrid Wadauer, Thomas Buchner, and Alexander Mejstrik (eds), The History ofLabour Intermediation: Institutions and Finding Employment in the Nineteenth and Early Twentieth Centuries [International Studies in Social History Volume 26]. Berghahn Books, Oxford and New York, 2015, 117-150. I wish to thank Sigrid Wadauer and Malcolm Mansfield for their valuable suggestions.

Knotter, Ad, Transformations of Trade Unionism: Comparative and Transnational Perspectives on Workers Organizing in Europe and the United States, Eighteenth to Twenty-First Centuries. Amsterdam, Amsterdam University Press, 2018 DOI: 10.5117/9789463724715_CHO5 
According to the 1815 statutes of the Vienna hatters' guild, each Sunday, Monday, Tuesday, and Thursday between 2.00 and 4.00 pm masters in need of help and journeymen in need of a job were to meet in the guild's lodging house (Herberge). ${ }^{1}$ As late as 1870 , Vienna hatters (Hutmacher) still had their own labour exchange in this Herberge, where members of the hatters' union spent their free time, and non-Viennese hatters had to present themselves. When there were hands needed in a workshop, the master sent one of his older workmen to the lodging house to find one, or he went there himself. By centralizing the local exchange of supply and demand of labour in the Herberge, the hatters' journeymen were able to control labour supply, as well as maintain their standard wage rate. Conflicts with employers on this issue, or between workers themselves, were settled in the lodging house, and there was 'no mercy' with journeymen accepting work below the traditional standard. ${ }^{2}$

Everywhere in pre-industrial Europe, journeymen and day labourers presented themselves in actual marketplaces, public houses, or public squares to be hired. There they tried to use these labour exchanges as instruments to regulate labour supply and wage standards. By means of placement control, competition for jobs could be limited, and employers or fellow journeymen could be forced to comply with wage rates. ${ }^{3}$ London tailors had used pubs as 'houses of call' or labour exchanges since at least the eighteenth century. ${ }^{4}$ In 1747 a house of call was described as 'an ale-house, where they generally use, the landlord knows where to find them, and the masters go there to enquire when they want hands'. As of 1811 , 'in large concerns it is very common for the master to send to a house [of call] for a "squad" of ten men and a captain, and to another for six men and a captain, and so on'. The houses of call were also the 'very basis and foundation' of the journeymen's association, and 'in all parts of the metropolis these houses are established and every journeyman is compelled to belong and resort to a Society there formed'. Here was where the union organized strikes and regulated the labour supply, as an eighteenth-century account makes clear:

$1 \quad$ Ehmer, 'Tramping Artisans', 167.

2 Sekirnjak, Damals und heute, 25, cited by Ehmer, Soziale Traditionen, 282-283. On the importance of this kind of Herberge in the early Vienna trade union movement: ibid., 274, 278.

3 Lis and Soly, “An Irresistible Phalanx"', 31; on the relationship between pubs as labour exchanges and strike propensity: Reith, 'Arbeitsmarkt und Gesellenstreiks', 198, 212.

4 Schulte Beerbühl, Vom Gesellenverein zur Gewerkschaft, 185-191. 
About the beginning of the year 1763, we looked upon it that Mr Dove, Mr Fell, and Mr Mason, three masters, were stirring up strife against us: so we fixed upon them that they should not be served. We insisted upon the men that worked for them to come away and leave them: it was a general resolution they should have no men work for them. The master of the House of Call sends the men, and if he sent any there, the body of men in that house would be fined. ${ }^{5}$

In seventeenth-century Amsterdam - to give another example - the unruly cloth shearers controlled the admission of outsiders to their trade by obliging them to wait their turn to be employed at the Oude Brug (Old Bridge), which functioned as a regular open-air labour exchange. The shearers also held meetings there during their frequent strikes. ${ }^{6}$ It is easy to imagine that in such places, where the effects of changing market forces were clearly visible, pressure on wages provoked immediate action. The most famous example of a labour exchange developing into an instrument of wage control is the Place de Grève in Paris, which lent its name to the French word for strike (grève). Situated between the Hôtel de Ville and the river Seine (grève also means 'sandy riverbank'), this square provided daily opportunities for workers in the building trades to present themselves to employers, masters, and contractors, who then selected those they could use. It was the regular labour market for migratory masons from the Limousin area. ${ }^{7}$ By organizing themselves and withholding labour supply (se mettre en grève) workers could counteract the effects of oversupply. ${ }^{8}$

In 1621 there was already a city ordinance requiring all carpenters, masons, roofers, and plumbers to assemble periodically at the square to agree upon a citywide wage scale (tarif). ${ }^{9}$ Negotiated wages at the Place de Grève (prix fait en place de grève) could also be enforced in court, as Alain Cottereau

5 Quotations ibid., 185, 187 and 189; on 'houses of call' as centres of the tailors' strike in 1763 also: 286 .

6 Knotter and Van Zanden, 'Immigratie en arbeidsmarkt', 411; Dekker, 'Labour Conflicts', 393. See also Chapter 1 in this volume.

7 Harison, 'The Rise and Decline of a Revolutionary Space', with extensive references on the history of the Place de Grève.

8 Schöttler, Die Entstehung der,Bourses du Travail', 29. The waiting room in the Paris Bourse du Travail was called salle de grève: ibid., 65. There was a labour market in the Place de Grève (now Place de l'Hôtel de Ville) until the Second World War: Luciani, 'Logiques du placement ouvrier', 8.

9 Harison, 'The Rise and Decline of a Revolutionary Space', note 55. 
has shown using a case from $1791 .^{10}$ The Place de Grève was the most visible place of labour market intermediation in eighteenth- and nineteenth-century Paris, amid a variety of smaller stations d'embauchage and bureaux de placement, ${ }^{11}$ where, as Steven Kaplan has demonstrated, journeymen in all kinds of corporations in the eighteenth century struggled with their masters to win control of job placement. ${ }^{12}$

The above-mentioned examples of collective action to control wages by labour exchanges indicate how inadequate it is to consider these to be neutral institutions that only facilitated the labour market by bringing together (information on) supply and demand. Rather, they were also instruments of market control. To cite a German historian of Arbeitsvermittlung in the eighteenth century:

Historically, labour market intermediation proved to be not just an effective instrument of allocation, but also a first-class instrument of power, because it enabled participants to influence entry to the labour market. Whoever was able to control the institution of labour exchange could also influence the price of labour. ${ }^{13}$

This was true not only of eighteenth- and nineteenth-century forms of labour market intermediation, but also of the public labour exchanges that were established all over western Europe at the beginning of the twentieth century. Their implicit and explicit aim was to bring order to the labour market by regulating and controlling supply. In spite of the liberal ideology that market actors might profit equally from exchanging (information on) supply and demand, the uncertainties of the labour market forced those involved to organize the outcome of the process themselves.

This chapter focuses on the changing role of trade unions in organizing labour intermediation in several European countries around 19oo. Their

10 Cottereau, 'Droit et bon droit', 1528. I owe this reference to Malcolm Mansfield.

11 Kaplan, 'La lutte pour le contrôle du marché du travail'. Next to the Place de Grève as a meeting place for building workers, Kaplan (p. 363) mentions the rue Aubry-le-Boucher and the quai de Gesvres for masons, carpenters, and painters; the rue de la Poterie and the rue des Écouffes for pastry bakers and woodworkers. Some nine other occupational stations d'embauchage in nineteenth-century Paris are summed up by Luciani, 'Logiques du placement ouvrier', note 1. See also Boll, Arbeitskämpfe und Gewerkschaften, 539-543.

12 Kaplan, 'La lutte pour le contrôle du marché du travail', 363 . He gives several examples of journeymen struggling for placement control.

13 Schröder, 'Arbeitslosenfürsorge', 24. 
changing role will be illustrated by developments in Germany, Austria, France, Great Britain, the Netherlands, Belgium, and the Scandinavian countries. My aim is to show that from the end of the nineteenth century trade union intermediation was incorporated in government-led labour exchanges everywhere, be it locally or nationally, and that in this process intermediation was transformed from an instrument of wage control by trade unions into an instrument of control of the unemployed by public labour exchanges. In all of these countries, trade unions originally claimed a monopoly on the organization of intermediation to prevent oversupply in the market and downward pressure on wages. However, a trade union monopoly on labour exchange was never realized anywhere. Trade unions therefore had to employ another method to prevent a decline in wages in bad times: unemployment insurance. In the end, the moral hazard associated with this type of insurance forced unions to cooperate with employers and authorities to control the unemployed. Those out of work were now required to register at public labour exchanges to confirm their willingness to work. In this way the labour supply was in effect split into 'fit' and 'unfit' workers. Supported by unemployment benefits, the former group could be held 'in reserve' for the next upturn (assuming there would be one soon); the latter was relegated to outside the labour market, or to an 'external' market of informal or second-rate jobs. One of the major effects of this change was to reorganize labour market intermediation on a territorial instead of a craft basis.

While these developments can be recognized all over Europe, there were clear national variations, both in the way trade unions were incorporated into public labour exchanges and in the timing of these changes. These variations can be related to political differences, like the strength of liberal reformers (for instance, in Belgium and Great Britain), social democracy (for instance, in Germany), or syndicalism (in France), but also to developments in the labour markets themselves (artisan labour markets in France, where developments lagged behind, vs industrial labour markets in Britain, where a centralized system of labour exchanges was established at a relatively early date). In this respect it is also interesting to study the international transfer of ideas and concepts of labour exchange, and the institutional setting of these transfers, for instance in international conferences of social reformers and statisticians in the beginning of the twentieth century, of which the one in Paris in 1910 is specifically relevant because it was devoted to the issue of control of the unemployed. To begin with, however, I will provide an overview of the organization of the labour market before labour market intermediation was institutionalized in public exchanges. 


\section{Before the public labour exchanges}

\section{Tramping}

Forms of labour recruitment or intermediation before there were public labour exchanges were based primarily on personal, face-to-face contact between employers and workers at the moment of selection and hiring. Contacts were made on a relatively small scale (as the examples above make clear). In pre-industrial Europe - far into the nineteenth century - supply and demand in urban artisan trades were balanced by peculiar institutions such as the French compagnonnages (journeymen's associations), which organized the traditional touring through France. ${ }^{14}$ The labour market intermediation of the compagnonnages also served to maintain a standard wage. They regulated labour mobility in the country and advised their members about places where labour was remunerated best, while prohibiting access to cities where masters were demanding and paid badly. The compagnon was not allowed to look for a job himself or to accept work for a lower tariff than his fellow journeymen. ${ }^{15}$

The English 'tramping artisan' based his job search as an organized tradesman on 'vacant lists' or 'vacant books'. These were maintained by a network of 'houses of call', often public houses that served both as centres of trade union activity and sites to organize the mobility of union members out of work. Unions supported tramping with travelling relief, which later developed into an unemployment benefit. For the tramp, the house of call was first and foremost a labour exchange. 'Vacant books' were kept in public houses right up to the time of the introduction of public labour exchanges in the early 1900 . ${ }^{16}$ However, in Britain at the end of the nineteenth century travelling was declining as a feature of union activity. ${ }^{17}$

The tradition of Gesellenwanderung in the German-speaking countries was based on a comparable system of meeting places. The Herberge was the equivalent of the British house of call. A travelling journeyman did not try to make contact with an individual master but rather sought out the lodging house for his craft. ${ }^{18}$ In nineteenth-century Germany and Austria, corporatist and trade union exchanges in public houses (and so-called

14 Adell-Gombert, Des hommes de devoir.

15 Luciani, 'Logiques du placement ouvrier', 9.

16 Leeson, Travelling Brothers, 132, 137. A classical study is Hobsbawm, 'The Tramping Artisan';

see also Southall, 'The Tramping Artisan Revisits'.

17 Mansfield, 'Labour Exchanges', 455.

18 Ehmer, 'Tramping Artisans', 179-181. 
Innungen) functioned as networks of agencies for artisan labour. In the Austrian Empire in 1898 it was reported: 'The Herberge still is [...] into the present [...] the common market place for supply and demand of workers in small businesses. ${ }^{19}$ As Sigrid Wadauer argues: 'Labour market intermediation and support meant influencing wages and working conditions and therefore were of primary importance for working men's associations and trade unions. ${ }^{20}$ In earlier times, journeymen also tried to organize supply this way: "The regulation of labour supply was one of the first goals in the programme of journeymen associations, as they soon became aware how important it was to keep the exchange of labour in their own hands in their struggle with the masters. ${ }^{21}$ Reminiscences of the Gesellenwanderung could be found in the travel funds of the early German trade unions. ${ }^{22}$ The travel funds later developed into trade union unemployment insurance. ${ }^{23}$

\section{Places de grève and Gesindemärkte}

Apart from these urban institutions, there were concrete markets for labourers in public places, where demand and supply met quite literally. In France these were named places de grève, after the Parisian model. ${ }^{24}$ Yet they could be found all over Europe, in towns as well as in rural areas. The great French ethnologist Arnold Van Gennep thus described such a market as follows:

Those who are looking for employment come together in a location fixed by tradition: the church square, a market place, a designated place at a street or cross-roads [...]. The future masters examine the boys and the girls, the men and the women, as if they are selecting draught animals. ${ }^{25}$

19 Statistisches Departement (ed.), Die Arbeitsvermittlung, cited by Wadauer, 'Vazierende Gesellen', 109 .

20 Ibid., 109-110. On Innungen in Germany: Schmuhl, Arbeitsmarktpolitik, 26.

21 Statistisches Departement (ed.), Die Arbeitsvermittlung, 96. See also Schröder, 'Arbeitslosenfürsorge', 53 .

22 Faust, Arbeitsmarktpolitik im deutschen Kaiserreich, 137; idem, 'Arbeitsvermittlung und Arbeitslosenversorgung', 121.

23 Risch, 'Gewerkschaftseigene Arbeitslosenversicherung', 518. On the British case: Schulte Beerbühl, Vom Gesellenverein zur Gewerkschaft, 227.

24 Luciani, 'Logiques du placement ouvrier', 7; Rudischhauser and Zimmermann, “'Öffentliche Arbeitsvermittlung"', 101.

25 Van Gennep, Manuel de folklore français, 2040, cited by Schöttler, Die Entstehung der 'Bourses du Travail', 198, note 30 . 
In rural areas in German-speaking countries there were so-called Gesindemärkte, and there are indications that these also functioned as wage regulators, at least in the eyes of observers in Bitburg (in the western German Eifel) in 1877: 'Many shortsighted employers are against this institution, which, however, is crucial to prevent downward pressure on servants' wages. ${ }^{26}$ Concentrating the market in one place and at one moment in time made it transparent and helped to maintain customary hiring conditions. Yet in Germany, from medieval times, the unifying effect of local markets for rural labour was undermined by Gesindemäkler, private agents (or brokers) for the recruitment of labourers. ${ }^{27}$

\section{Calling around}

Another, and at the end of the nineteenth century perhaps more common, way to find work was just looking around. Job seekers would ask at factory gates, building sites, port entrances, mines (Zechenlaufen in Germany), and so forth. Under different names this practice can be observed all over Europe. In Norway the phenomenon was described as omskådning ('looking around'), ${ }^{28}$ and in the Netherlands it was called leuren om werk ('hawking for work'). ${ }^{29}$ In England it was known as the 'calling-round system,, ${ }^{30}$ and also as 'hawking':

At the close of the nineteenth century the phrase 'hawking labour' was commonly invoked to describe the process whereby workers roamed from employer to employer seeking work. It was time-consuming, costly, and demoralizing. ${ }^{31}$

The German term for this method was Umschau. A Prussian observer remarked in 1894:

The whole area, which until now has not been regulated by labour exchanges, is still - apart from the Gesindemärkten ['people's markets'

26 Cited by Neu, 'Die Gesindemärkte der Südeifel', 519 .

27 Schröder, 'Arbeitslosenfürsorge', 68-69.

28 Edling, 'Regulating Unemployment the Continental Way', 28.

29 Knotter, Economische transformatie, 117; see also Gewin, Arbeidsbeurzen, 279.

30 Dearle, Problems of Unemployment, 82-96.

$3^{1}$ King, Actively Seeking Work?, xiii; for the term 'hawking', see also Mansfield, 'Labour Exchanges', 453; Beveridge, Unemployment, 197: 'The prevailing method of selling labour is to hawk it from door to door.' 
or 'people's exchanges'] in some towns in the east and in rural areas of Schleswig-Holstein - covered by the Umschau in its different forms..$^{22}$

Although the practice of Umschauen was already known in the context of urban crafts whenever journeymen helped each other looking for work, in the nineteenth century it became associated with unorganized labour markets in manufacturing, construction, mining, and port industries. ${ }^{33}$ In 1902 it was disparaged as the 'ever more downgrading power of the Umschau'.34 The Austrian bookbinders' union was also quite negative regarding this practice:

In that period [189o], the labour market was characterized by a sinister freedom. The employer could choose whoever he liked, and pay him whatever he wanted; also the hand had to accept whatever was offered to him. The most common way to find work was Anklopfengehen [knocking on doors]. Most of the time, the unemployed waited at the factory gates from early in the morning; when it was believed that here or there was some work to do, and people hoped to get a job in one way or another, they went hawking their labour from shop to shop, just like a street whore. ${ }^{35}$

In the light of the foregoing argument, it is no surprise that trade unions opposed the Umschau and other individual ways of finding work because they enabled, and easily led to, Lohndrückerei (wage cutting). $\cdot^{36}$ Attempts by unions to establish their own labour exchanges were intended to counteract this effect. ${ }^{37}$ Consequently in 1895 the German union of kid glovemakers (Glacéhandschuhmacher) wanted to maintain their own agency so as to prevent the loss of control brought on by the extension of the Umschau system:

to avoid any oversupply of labour as much as possible; in this way our members can be freed from the degrading Umschauen, which often

\footnotetext{
32 Evert, 'Die Arbeitsvermittlung in Preußen', 13, cited by Faust, Arbeitsmarktpolitik im deutschen Kaiserreich, 48.

33 Schröder, 'Arbeitslosenfürsorge', 53-54, refers to the term 'Umschau' in the context of journeymen's monopolies in labour intermediation; see also Schmuhl, Arbeitsmarktpolitik, 21; for the Swiss case: Gruner, 'Arbeitsvermittlung und Arbeitslosenversorgung', 244.

34 Ignatz Jastrow, cited in Schmuhl, Arbeitsmarktpolitik, 21.

35 Cited by Wadauer, 'Vazierende Gesellen', 108. On the importance of Umschau in Austria, especially in manufacturing: Statistisches Departement (ed.), Die Arbeitsvermittlung, 286-288.

36 Wadauer, 'Vazierende Gesellen', 110, 138.

37 Faust, Arbeitsmarktpolitik im deutschen Kaiserreich, 48.
} 
resembles begging for work, and also opportunities will be created to withhold supply to employers who distinguish themselves by exploiting their workers, or sharply oppose their just demands..$^{38}$

To circumvent both the relative arbitrariness of the calling-round system and trade union control on job placements, employers often made use of informal recruitment methods. Hence, they relied upon workers' recommendations of acquaintances, family members, personal contacts, or other sources of information. ${ }^{39}$ In the case of the Parisian metal trades, it was said (in 1895) that the majority of people in workshops were hired by acquaintance (connaissance) or by comrades. ${ }^{40}$ In many nineteenth-century industries, workers were subcontracted in teams. The contractors or foremen who hired them were thus acting as brokers in the labour market. ${ }^{41}$ Contractors as intermediaries were also quite common in mobilizing migratory labour in seasonal trades such as construction and agriculture. Just one example is the yearly recruitment of masons and other construction workers from northern Italy for the Vienna labour market 'by the intermediation of socalled Capi, contractors, team leaders'. Brickmakers from northern Italy were also mobilized by Ziegelmeister as Accordgruppen-Führer. ${ }^{42}$

\section{Private agencies}

In the last decades of the nineteenth century, urban workers in specific branches became more dependent on commercial employment agencies. According to Faust, these were responsible for two-thirds of all placements in Prussia and Bavaria in the 189os. At the same time, they had a bad reputation. ${ }^{43}$ In 1894, 632 of a total of 5,216 Prussian Stellenvermittler (job agencies) were prosecuted 761 times, and 345 were the object of complaints of malpractice filed with the police. ${ }^{44}$ All parties involved agreed that,

38 Cited ibid., 8o, and Faust, 'Arbeitsvermittlung und Arbeitslosenversorgung', 115 .

39 Rudischhauser and Zimmermann, “'Öffentliche Arbeitsvermittlung”, 101; Ansell, Schism and Solidarity, 65; Statistisches Departement (ed.), Die Arbeitsvermittlung, 283-286.

40 Cited by Ansell, Schism and Solidarity, 65.

41 Luciani, 'Logiques du placement ouvrier', 6; Topalov, Naissance du chômeur, 44-45; Lefèbvre, L'invention de la Grande Entreprise; Van den Eeckhout (ed.), Supervision and Authority. See also Chapter 5 in this volume.

42 Statistisches Departement (ed.), Die Arbeitsvermittlung, 291-293.

43 Faust, 'Arbeitsvermittlung und Arbeitslosenversorgung', 110. See also Schmuhl, Arbeitsmarktpolitik, 22-23.

44 Faust, Arbeitsmarktpolitik im deutschen Kaiserreich, 48. 
because of agents' personal financial interests, they were easily tempted into unrealistic intermediations. ${ }^{45}$

Commercial agencies were active in sectors with a low trade union density, such as agriculture, domestic services, seafaring, and the catering industry. ${ }^{46}$ In Kristiania (today's Oslo), a public labour exchange was established in 1894 after private placement agencies had come under attack following a number of scandals. ${ }^{47}$ In Britain at the start of the twentieth century, fraud and malpractice in private bureaux formed one of William Beveridge's arguments in favour of public labour exchanges. ${ }^{48}$

In Paris, trade unions initiated a Ligue pour la suppression des bureaux de placement, and in 1886 they launched massive protests (including petitions and demonstrations) against fraudulent practices of private bureaux de placement. A trade union-dominated municipal Bourse du Travail (see below) was established in response to these protests. However, the bureaux de placement continued to be popular among specific employers in branches where trade unions were weak, particularly in the food and catering industries. ${ }^{49} \mathrm{In}$ 1910, their role was still being hotly debated by French social reformers. ${ }^{5^{0}}$

\section{Trade union attitudes}

\section{Trade union agencies and the Parisian Bourse du Travail}

In the nineteenth century trade unions claimed a monopoly on the organization of labour supply. Their aim was to prevent downward pressure on wages from the entry of low-paid outsiders. Union exchanges were part of a system to regulate the conditions of access to a craft..$^{1}$ The Parisian Bourse du Travail was established for this reason in 1886 . The centralization of labour market intermediation was initiated by trade unions and backed by municipal authorities..$^{2}$ The Bourse was a combination of a local labour

45 Cited in idem, 'Arbeitsvermittlung und Arbeitslosenversorgung', 111. See also Statistisches Departement (ed.), Die Arbeitsvermittlung, 77-93.

46 Faust, Arbeitsmarktpolitik im deutschen Kaiserreich, 49.

47 Edling, 'Regulating Unemployment the Continental Way', 28.

48 Beveridge, Unemployment, 240.

49 Schöttler, Die Entstehung der 'Bourses du Travail', 6o, 99.

50 Rudischhauser and Zimmermann, “'Öffentliche Arbeitsvermittlung”', 102.

$5^{1}$ Whiteside, 'La protection du métier'.

52 Schöttler, Die Entstehung der 'Bourses du Travail'; more recently: Ansell, Schism and Solidarity, 110-117, and Hamelin, Dossier: 'Aux sources de l'histoire syndicale française', 116-117. 
exchange and a gathering place for trade unions and their members; it also coordinated strikes. This Parisian concept was rapidly adopted throughout France: in 1900, there were bourses du travail in 77 large and medium-sized French towns. ${ }^{53}$ Significantly, although the bourses competed with the (by then) old-fashioned and rather conservative compagnonnages, they were often established in cities where compagnonnages had strong roots. In fact, the idea of a bourse as a place where workers could find both a job and a professional community had much in common with the corporatist traditions of the compagnonnages. ${ }^{54}$

Trade unions elsewhere in Europe - I know of Italy, the Netherlands, Belgium, and the Scandinavian countries - tried to follow the French model. ${ }^{55}$ In Italy comparative institutions were established around 1900 under the name Camere del lavoro, building upon earlier initiatives of individual trade unions. ${ }^{5}$ An 1888 Scandinavian labour congress, held in Copenhagen, called for the establishment of union-led labour offices that were to be publicly funded. In Denmark, Sweden, and Norway unions demanded bourses du travail (arbejderbørs), 'like the one in Paris', because these 'would [...] strengthen existing union-run placement activities which aimed at protecting the trade by limiting competition'. ${ }^{57}$ Especially in Denmark union-linked placement activities achieved relative strength; many unions, particularly those organizing skilled workers, had well-functioning services of this kind..$^{8}$

\section{Germany, Austria, and Great Britain}

In Germany, trade unions also favoured trade union control over intermediation, as Anselm Faust has argued in his study on German labour exchanges. ${ }^{59}$ The socialist Freie Gewerkschaften had established their own exchanges from the 1860 s and 1870 s onwards. Rapid growth, especially in the 188 os, meant that there were 967 union exchanges organized locally

53 Rudischhauser and Zimmermann, “Öffentliche Arbeitsvermittlung”', 109.

54 Ansell, Schism and Solidarity, 115, 127. He computes a strong statistical correlation between bourses and cities with a tradition of compagnonnage. On the relationship between the concept of bourse du travail and compagnonnage also: Luciani, 'Logiques du placement ouvrier', 14.

55 Gewin, Arbeidsbeurzen, 249-250; Bevaart and Veen, De rechten man op de rechte plaats, 21; Van Bekkum, Tussen Vraag en Aanbod, 149-150.

56 Musso, La regole e l'elusione, 33-43.

57 Edling, 'Regulating Unemployment the Continental Way', 31.

$5^{8}$ Ibid., 32-33.

59 Faust, 'Arbeitsmarktpolitik in Deutschland', 262. 
for individual crafts by $1904 .{ }^{60}$ Union members receiving benefits were required to use the union agencies, and looking around for work individually was prohibited. ${ }^{61}$ Until the end of the nineteenth century, German trade unions held the position that 'those who sell their labour power have a right to decide about how to bring it to the market, ${ }^{62}$ In 1896 the Congress of the Freie Gewerkschaften promoted a system like the French bourses du travail: "The state can provide buildings, like it builds exchanges for merchants, but everything else can be left to the trade unions [...]. The exchange of labour itself should be the task of the unions. ${ }^{, 63}$

An Austrian trade union congress, also held in 1896, likewise argued against bipartite and state or municipal exchanges. The congress 'called it a duty for every trade union to work seriously towards the establishment of their own labour exchange, and to energetically oppose any further experiment to organize labour market intermediation by the state or the municipalities without the exclusive control of the trade unions'. ${ }^{64} \mathrm{An}$ Austrian report of 1898 substantiated 'the progress of the organization of workers in trade unions that everywhere try to draw the exchange of labour towards themselves' ${ }^{6}$ It counted 249 trade union exchanges in the Austrian Empire as a whole. ${ }^{6}$ In most cases members looking for work were obliged to use the union's exchange. The aim was to protect local wage standards: 'the permission [to accept a job] can be refused if the position concerned does not comply with local customs or agreed conditions of labour'. ${ }^{67}$

British trade unionists originally appear to have had a comparable attitude towards public exchanges. Like their continental counterparts, they wanted exchanges to be administered wholly by the unions for the benefit of their members. ${ }^{68}$ In addition, they were suspicious of public exchanges, and not without reason. In 1906, Beveridge, the liberal proponent of central labour exchanges, 'refused to concede that exchanges should only advertise

6 Schmuhl, Arbeitsmarktpolitik, 24.

61 Conrad, Die Organisation, 33-35, 49.

62 Cited by Faust, Arbeitsmarktpolitik in deutschen Kaiserreich, 224. See also Conrad, Die Organisation, 27-28.

63 Protokoll der Verhandlungen, cited by Rudischhauser and Zimmermann, “'Öffentliche Arbeitsvermittlung"', 112. On the Paris Bourse du Travail as an example in Germany: Faust, Arbeitsmarktpolitik im deutschen Kaiserreich, 82 note 126.

64 Statistisches Departement (ed.), Die Arbeitsvermittlung in Österreich, 215.

65 Ibid., 119 .

66 Ibid., 219 .

67 Ibid., 220.

68 King, Actively Seeking Work?, 48. 
situations which paid either trade-union rates or the local standard wage'. 99 Winston Churchill, then president of the Board of Trade and a leading official in the debate on public labour exchanges, was equally 'uncompromising about the use of the exchange to enforce standard rates in wages'. ${ }^{\circ}$ Trade unions in 1906 stipulated that they should be permitted to maintain their own 'vacant books' (as in the houses of call mentioned above) at each public exchange and, 'with the exception of the place of registration [...] be allowed to continue their present methods'. Furthermore, they demanded that 'where an organized system of registration [like in the houses of call] is already in existence, covering any trade, such registration shall be accepted [...] in the locality [of the public exchange] as sufficient for the purposes of that trade'. ${ }^{71}$ The first public London labour exchanges combined their operations in 1906. Unions were indeed allowed to deposit their own 'vacant book' at each exchange. They were allowed to use its facilities, while at the same time retaining their own rules and systems of information. ${ }^{2}$

\section{An artisan approach}

Trade-based exchanges were more a system of the artisan past than of the industrial future, however. In Germany, labour union intermediation was able to exert a measure of influence only 'in small or medium-sized firms, with many skilled and highly organized occupations. ${ }^{73}$ In the Swiss case, the limitations were also apparent, as documented by Erich Gruner:

The higher the degree of organization became, the less trade unions were willing to abstain from a monopoly in labour exchange [...]. Their chances to succeed were best in branches where labour markets were less transparent, with small firms dominating, and loose ties between employers. The chances for trade unions to dominate the exchange of labour were highest in artisan trades. ${ }^{74}$

The explicit aim of Swiss unions was to combat the Umschau: 'Their strategy started with a ban by the union board on the Umschau by their members.' 75

69 Harris, Unemployment and Politics, 203.

70 King, Actively Seeking Work?, 43; on this issue also Mansfield, 'Flying to the Moon', 29.

71 Cited by King, Actively Seeking Work?, 34.

72 Harris, Unemployment and Politics, 203; see also Beveridge, Unemployment, 185.

73 Schmuhl, Arbeitsmarktpolitik, 25.

74 Gruner, 'Arbeitsvermittlung und Arbeitslosenversorgung', 247.

75 Ibid., 247 . 
Trade union agencies were well represented in the Brussels luxury trades. Especially among the bronze workers, compositors, typographers, coach makers, hatters, and glove-makers, the workers tried to dominate the labour market by developing labour exchanges managed by the trade unions. ${ }^{76}$ On account of this development, it has been argued that the concept of trade union control in labour exchanges arose at a specific moment when corporatist institutions in small-scale industry - such as the urban luxury trades - were declining but still functioning. ${ }^{77}$ In this respect, a parallel might be located in the programme of productive associations in the early labour movement. ${ }^{7}$ It is thus interesting to note that the independent French bourses du travail were dominated by trade unions of small-scale artisans (or semi-artisan craftsmen) and that industrial unions were underrepresented. ${ }^{79}$ Likewise, small employers seem to have favoured union control. According to one observer, in Saint-Étienne small masters were in favour of the union exchanges and turned to them to look for labourers, but the large ones were against and combated them. ${ }^{80}$

\section{British trade unions at the end of the nineteenth century}

\section{Trade union agencies}

The British Board of Trade's Report on Agencies and Methods for Dealing with the Unemployed (1893) illustrates trade union practices in these matters. ${ }^{81}$ Craft unions, mainly in artisan trades, such as the Amalgamated Society of Carpenters and Joiners, the Typographical Association, and the Alliance Cabinet Makers' Association, but also in manufacturing, such as the Amalgamated Society of Engineers or the Boiler Makers' and Iron Shipbuilders' Society, combined unemployment insurance with forms of

76 Le placement d'utilité publique, 9, cited by Deslé, Arbeidsbemiddeling, 35. It is no coincidence that most of the unemployment funds in Belgium in 1890 could be found precisely in these Brussels luxury trades: Vanthemsche, 'De oorsprong van de werkloosheidsverzekering', 131.

77 Deslé, Arbeidsbemiddeling, 56-57.

78 See Lenger, 'Beyond Exceptionalism'.

79 Schöttler, Die Entstehung der 'Bourses du Travail', 93-95.

8o Cited ibid., 108. See for the British case Whiteside, 'La protection du métier', 34.

81 Board of Trade, Report on Agencies, retrieved 15 February 2011 from http://www.archive. org/details/reportonagenciesoogrearich; also as Parliamentary Papers 1893-94, vol. 82. See also: Whiteside, 'Définir le chômage'; Topalov, Naissance du chômeur, 63, 226-229. Beveridge, Unemployment, 257-261, Appendix B.3: 'Trade Union Travelling Benefit and Registries', cites extensively from the report. 
registering unemployed members in 'vacant books' at the meeting house of the branch, usually a public house. Sometimes there were also 'vacant offices' where the unemployed members of all local branches had to sign in every day. On this basis, an intricate system of supra-local intermediation was maintained, as in the case of the well-organized engineers. ${ }^{82}$

In many cases, nonetheless, allocation of unemployed members by the union was only one possible way to get a job, and for employers it could be a last resort, as reported by the Steam Engine Makers' Society: 'Employers requiring men, or foremen acting on their behalf, may send there [the branch club-house] for men if they are unable to obtain them in the usual way from among the applicants at the shop gate, or through other members working in their shop. ${ }^{83}$ In this and other craft unions, 'hawking' labour was as common as the allocation of jobs by the union. Although in the case of the pattern makers it was 'a very common thing for employers to apply to the society for men in times of good trade', members out of work would also 'visit such workshops as they may think most likely to need men, and make application to the foremen., ${ }^{84}$ For instance, firms often sent representatives to the headquarters of the National Society of Amalgamated Brass Workers in Birmingham to 'take artisans on the recommendation of the general secretary [...]; the men themselves, however, often make personal applications for work. ${ }^{85}$ In the case of shipwrights, the manner of seeking a job also varied: 'Employers or their agents frequently apply to the society for men [...]. No objection, however, is offered to men applying to employers direct, provided they do so in the manner customary in the district.' Yet in places like Dundee and Liverpool, 'the method generally adopted is for members to congregate at the gates or starting places of such firms as are thought likely to require assistance. In addition to this, members visit the various docks and yards, and thus frequently obtain casual employment. ${ }^{, 86}$

With respect to bricklayers, 'employers seldom apply to the union for men, work being usually obtained by personal application or by the cooperation and assistance of other members, ${ }^{87}$ At the Typographical Association, 'employers requiring assistance apply to the secretary at the society house for a list of members signing the call-book, selecting those they require,

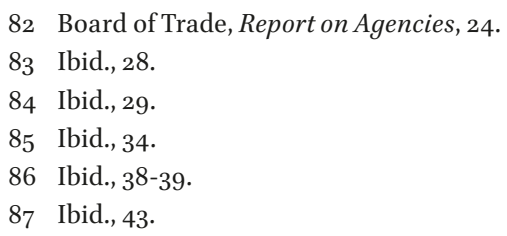


but members also apply to employers and overseers for employment at their respective offices, ${ }^{88}$ In the textile industry, the 'calling-round system' was even more widespread. Unemployed members of the Amalgamated Association of Operative Cotton Spinners 'usually go round to the various mills inquiring for situations, it being customary for the foreman either to take their names and addresses or to communicate with them through some friend employed in the same mill. This system obviates the necessity of employers having to apply to the union. ${ }^{89}$

The mode of obtaining employment in the Amalgamated Association of Card and Blowing Room Operatives was 'by personal application at the mills, which is supplemented to some extent by information given and received by the branch secretaries at the society houses'..$^{\circ}$ At the West Riding of Yorkshire Power Loom Weavers' Association 'no vacant book is kept, nor does the union attempt to find employment for its members [...]. Except in rare cases, employers do not apply to the union for men, but members make application to the employers or their representatives for work. ${ }^{91}$ In the mining industry and for waterside labour, no provisions were made for out-of-work benefits nor for the placement of unemployed union members. ${ }^{92}$ As for factory workers more generally, it was reported that they 'usually introduce one another, that they answer advertisements, and very frequently find work through notices posted up outside the factories. ${ }^{93}$

A reader is compelled to conclude from this 1893 report that union-based exchanges were in no way able to impose a monopoly (any more?) and that unorganized forms of job seeking had become at least as important. Along with Beveridge, we may conclude from the report that 'even in the most highly organized trades the use of the union office as a labour bureau is hardly ever exclusive of other methods of seeking employment or obtaining workpeople. ${ }^{94}$ In its conclusion, the report itself avers that 'the bulk of the work of hiring labour and seeking employment will in most trades continue to be done directly between workmen and employers' ${ }^{95}$ British employers were also rather outspoken about the secondary role played by trade unions, observing in 1909 that the most common hiring methods were:

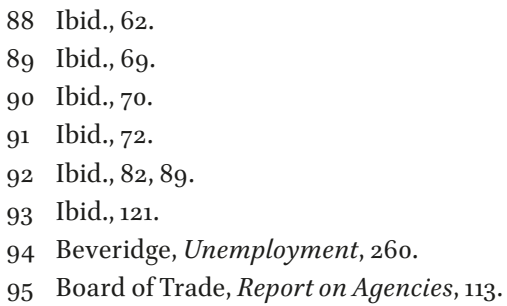


First, the foremen have usually in their possession a list of men out of work with whose capacity and character they are acquainted. Second, recommendations of other workmen on whose opinion the foremen can rely. Third, trade union and other organizations. And, fourth, the public press. ${ }^{96}$

On the basis of this source alone we cannot be sure about the extent of market control by craft unions earlier in the century. The information available on London trades in the first half of the nineteenth century provides a mixed picture. While there was close control in tailoring and printing, it was less pronounced in the building trades (e.g. carpentry). ${ }^{97}$ Nevertheless, it is tempting to conclude that processes of industrialization and casualization of labour markets in the last decades of the nineteenth century were responsible for undermining union regulation of labour market intermediation. Customary trade union controls were under threat from changing patterns of industrial relations. Among these were the rise of general unions, which lacked the close control over conditions and terms of employment that was typical of the skilled trades. ${ }^{98}$ It is at least clear by the end of the century that British unions could not prevent members from individually calling around for work. Perhaps we can also relate this development to the demise of craft-related systems of subcontracting in industry and the 'rise of the foreman', who recruited workers on an individual basis. 99

\section{Unemployment insurance and union control of the unemployed}

Close reading of the report cited above shows how the efforts of British trade unions to seek job placements for their members were related to another union method for preventing downward pressure on wages: unemployment insurance. In Britain, perhaps more than in France, ${ }^{100}$ union systems of trade regulation and control combined both features: trade unions offered help to out-of-work members in the form of placement and benefits. ${ }^{101}$ For the unions, the issue centred on wage control. In combination with benefits,

96 Cited by King, Actively Seeking Work?, 37.

97 Schulte Beerbühl, Vom Gesellenverein zur Gewerkschaft, 189-191.

98 Mansfield, 'Flying to the Moon', 28.

99 See Van den Eeckhout (ed.), Supervision and Authority.

100 Dreyfus, et al., 'Les bases multiples du syndicalisme'. See also Whiteside, 'Unemployment Revisited', 39 .

101 Whiteside, 'La protection du métier'; a short overview of unemployment insurance by British trade unions appears in Beveridge, Unemployment, 223-230. 
placement by the union enabled members to refuse work below the wage standards set by the unions, or to withhold supply in case of strikes. In this way a dilemma could be solved: if a worker refused to accept a rate lower than the one the union had set, should he be called 'unemployed' or 'on strike'? ${ }^{102}$ Unemployment benefits prevented members from being forced to accept work on non-union terms. In the case of the Amalgamated Society of Engineers it was argued that:

the unemployed benefit of the trade union acts as a regulator of the labour market. Practically, the trade union of this class is in a position to minimize the competition of the individuals composing it, by using this benefit for the purpose of lessening pressure upon the labour market. ${ }^{103}$

Sidney and Beatrice Webb, theorists of British trade unionism at the time, contended that unemployment benefits were primarily designed to deter unemployed workmen from undermining the level of wages and only secondarily to relieve distress. ${ }^{104}$ In many unions the out-of-work benefits were therefore not clearly distinguished from payments because of strikes. ${ }^{105}$ The demand for union control of labour market intermediation can therefore be seen as a part of the whole endeavour to keep wage rates up. However, the report cited above suggests that the mechanism of 'vacant books' served a further goal: the signing of the book by the unemployed member allowed the union branch secretary to verify that a man was really unemployed. ${ }^{106}$ The labour market intermediation of the Society of Engineers, for example, was meant to relieve the burden on the unemployment fund. Daily registration in the 'vacant book' in that society's houses of call was necessary 'to secure that the member would be easily available in the event of his services being required by an employer. ${ }^{107}$ The unions in the printing industries explicitly stated that 'any one refusing to go when called upon to do so forfeits that week's out-of-work pay', and 'those failing to answer a call are ineligible for out-of-work allowance for six days' ${ }^{108}$ As the benefit had to be raised by

102 Whiteside, 'Définir le chômage'; see also Luciani, 'Logiques du placement ouvrier', 14: 'la définition syndicale du chômage, exprimée comme l'impossibilité pour un ouvrier d'une profession déterminée, de trouver un emploi dans son métier au tarif normal'.

103 Board of Trade, Report on Agencies, 21.

104 Webb and Webb, Industrial Democracy, 161-162.

105 Harris, Unemployment and Politics, 297.

106 Ibid., 296.

107 Board of Trade, Report on Agencies, 22.

108 Ibid., 56, 59, 62, 63 . 
the members themselves, it was important to get the unemployed working as soon as possible and to control for applications without justification. To cite Beveridge once more: 'Unions come nearer than any other bodies to possessing a direct test of unemployment by which to protect their funds against abuse. They have [...] at least the beginnings of a Labour Exchange system. ${ }^{109}$ All this explains why union intermediation was meant only for unemployed members, not for employed members wanting to change jobs. In this sense the unions' labour exchanges acquired the function of controlling unemployed members at least as much as they controlled mobility in the labour market in general.

\section{The Ghent system: incorporation of trade unions into public labour exchanges}

\section{The Ghent system}

At this stage of the argument, I wish to redirect attention to the continent, to the city of Ghent in Belgium. The Ghent system, designed by the prominent liberal reformer Louis Varlez, provided municipal financial supplements to individual out-of-work benefits distributed by trade unions. It was a pioneering device and was soon adopted all over Europe. ${ }^{110}$ Trade unions in Ghent had cooperated with the municipal authorities in the administration of an Unemployment Fund (established in 1900), proving very strict in monitoring the willingness of unemployed members to accept work. In the process, they were also compelled to separate their unemployment and strike funds. These were, of course, two of the reasons why liberal reformers embraced this system.

Unions participating in the municipal Unemployment Fund had a strong interest in requiring that their unemployed members register daily at their office to determine whether individual applications were justified. ${ }^{111}$ In due time, however, most of the Ghent unions agreed that it would be better for monitoring purposes if unemployed members were registered at the existing public labour exchange. As a result, Varlez managed to convince the unions

109 Beveridge, Unemployment, 227.

110 Harris, Unemployment and Politics, 299; Schmuhl, Arbeitsmarktpolitik, 54-61; Steinmetz, Regulating the Social, 203-209. For the Swiss case: Gruner, 'Arbeitsvermittlung und Arbeitslosenversorgung', 254; for the Dutch and Scandinavian cases see below.

111 Vanthemsche, 'De oorsprong van de werkloosheidsverzekering', 145-146. 
in 1909 to participate in a municipal Labour Exchange, to be administered on a bipartite basis (by both employers and workers). A cooperative endeavour between the Unemployment Fund and the Labour Exchange was thereby forged, resulting in the transfer of union intermediation and control, as well as a sudden rise of union members applying at the Exchange in $1910 .{ }^{112}$

The Ghent unions had demanded that the bipartite municipal exchange would not accept job offers below standard rates or in the event of strikes or lock-outs. ${ }^{113}$ Yet in fact, they had to give up any independent role in the area of intermediation, as had been the original intention of Varlez, who considered trade union control of the labour supply detrimental. ${ }^{114}$

\section{Great Britain and Germany}

Elsewhere in Europe as well, this combining of compulsory registration of the unemployed at labour exchanges with unemployment insurance schemes modelled on the Ghent system persuaded trade unions to participate in bipartite administration of existing or newly established public labour exchanges. In Britain, trade unionists did not fully support public exchanges, fearing 'blacklegging' and 'wage cutting', until these could be reinforced by a system of unemployment insurance in 1912. ${ }^{115}$ According to José Harris in her study on English unemployment politics, some kind of incentive was necessary to persuade the better class of workmen to register at an exchange; and it was not until the payment of benefits came into operation in 1913 that the prejudice against public exchanges of organized workmen, at least in insured industries, was to a certain extent broken down. ${ }^{116}$

However, this was only after attempts by representatives of organized workers to use labour exchanges to improve their members' power in the labour market had failed. Once unemployment compensation was enacted by the government, the aim of controlling the unemployed competed with the earlier (opposing) aim of controlling the labour supply. ${ }^{117}$ The linkage between the placement of job seekers and the distribution of benefits became a defining feature of the organization of the labour market, as Beveridge had prescribed in his Unemployment: A Problem of Industry (1908): 'No scheme of insurance [...] can be safe from abuse unless backed by an

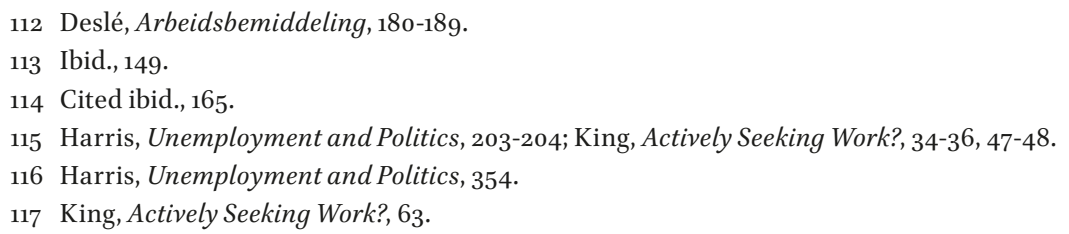


efficient organization of the labour market [i.e. an adequate system of labour exchanges]. ${ }^{118}$ Public labour exchanges became mechanisms through which the government could impose a division between unemployed workers into those worthy and those unworthy of receiving unemployment assistance. ${ }^{119}$

Nonetheless, it is a remarkable circumstance that in 1927 only 77 per cent of British union members claiming unemployment benefits signed on at public labour exchanges. Of the remaining 23 per cent considerably more than half proved their unemployment by signing vacant books kept under the supervision of full-time officers of their associations, while the remainder signed vacant books kept at places such as the branch secretary's residence, or a shop or public house. ${ }^{120} \mathrm{~A} 1920$ public enquiry into the work of the employment agencies, as analysed by Malcolm Mansfield, revealed that trade unionists perceived public labour exchanges as of little use to skilled and organized workers. They were especially condemned for their tendency to impose a uniform job search across a diversity of existing, tailor-made employment practices, including recruitment via foremen, union branches, and personal contacts. In the eyes of both employers and craft unions, public labour exchanges were of use only to 'unproductive' workers. Not surprisingly, such individuals found more support in the growing general unions for unskilled workers. ${ }^{121}$

In Germany, trade unions were also in favour of unemployment insurance, for the same reasons as their British counterparts. For them, the insurance should not only relieve the individual fate of the unemployed, but also, by lessening the pressure on the labour market, protect the terms of employment by preventing downward pressure on wages by the suffering of those looking for work. Labour exchanges that are aimed only at allocating labour should not give up this goal. ${ }^{122}$ Fanny Imle, a socialist expert in this field, claimed:

The awareness that one never again has to subject oneself - being unemployed and starving - to the terms of the employer, who not long before

118 Beveridge, Unemployment, 229.

119 King, Actively Seeking Work?, 19.

120 Ministry of Labour circular ED 5117/3/1927, dated 22 February 1928, cited by Lyddon, 'From Unemployment Benefit', 103.

121 Mansfield, 'Flying to the Moon', 29-34.

122 Faust, 'Arbeitsvermittlung und Arbeitslosenversorgung', 130. For the argument to set up unemployment insurance schemes by German trade unions to influence 'das Angebot auf dem Arbeitsmarkt', 'zur Aufrechterhaltung des Standardlohnes, des errungenen Minimums der Arbeitsbedingungen überhaupt', also Faust, Arbeitsmarktpolitik in deutschen Kaiserreich, 134, 156. See also Zimmermann, La constitution du chômage, 78-80. 
was fought courageously, has done more to raise the consciousness of the working class than a quickly won strike, whose results can be stolen piece by piece if the organization is weakened. ${ }^{123}$

The number of trade union unemployment funds in Germany grew from ten in 1891 to 44 just before the First World War. ${ }^{124}$ As in Britain, unions organized their own labour exchanges, both to control unemployed members and to prevent them from accepting jobs below the standard wage rate. ${ }^{125}$ Starting in the late nineteenth century, urban authorities began to recognize the need for measures to reorganize the labour market. By 1914 some fifteen German cities had adopted the Ghent system. ${ }^{126}$ Other ideas combining unemployment insurance and public labour exchanges were developed in German municipalities before the First World War. ${ }^{127}$ In the same period, trade unions gave up their resistance to cooperating in public labour exchanges, thereby abandoning the model of the French bourses du travail. ${ }^{128}$ In 1908 the trade union congress opted for bipartite municipal exchanges, and in 1913 it advised all associated unions to transfer their own placement bureaux to public exchanges. ${ }^{129}$

Strasbourg (at that time a German city) was the first to integrate a scheme of unemployment insurance with a central labour exchange managed by a joint bipartite committee. Trade union agencies and municipally subsidized schemes of unemployment benefits were absorbed by the municipal labour bureau in 1906. By contrast, in the same period Ghent continued to leave supervision of the unemployed to the trade unions themselves - as we have seen above. According to Beveridge, who in his book Unemployment devoted an appendix of some fifteen pages to describing the German public labour exchanges, in Strasbourg there had 'been in force since the beginning of 1907 a scheme of augmenting from a municipal fund unemployed benefits paid by trade unions to their members; one of the conditions for the receipt of this municipal subsidy is regular registration at the Labour Office'. ${ }^{130}$

123 Imle, 'Die Ergebnisse der Gewerkschaftlichen Arbeitslosenunterstützung', 801, cited by Risch, 'Gewerkschaftseigene Arbeitslosenversicherung', 525, note 1.

124 Schmuhl, Arbeitsmarktpolitik, 53; Risch, 'Gewerkschaftseigene Arbeitslosenversicherung', 518-520.

125 Ibid., $5^{26-527 .}$

126 Whiteside, 'Unemployment Revisited', 40-42.

127 Faust, Arbeitsmarktpolitik in deutschen Kaiserreich, 147, 149-150, 152; also idem, 'Arbeitsvermittlung und Arbeitslosenversorgung', 129; Zimmermann, La constitution du chômage, 109, 119-135. 128 Ibid., 120.

129 Schmuhl, Arbeitsmarktpolitik, 40.

130 Beveridge, Unemployment, 245; cf. on the Strasbourg case: Zimmermann, La constitution du chômage, 128: 'Ce passage obligé par le bureau de placement [...] facilite le contrôle des 
Like Ghent, Strasbourg became one of the classic models for labour market reformers both inside and outside Germany. ${ }^{131}$ The combination of public labour exchange with the administration of unemployment benefits was then adopted by other municipalities. Beveridge was able to refer to a German 'movement to absorb competing institutions such as guild and trade union registries, and thus to centralize and unify the whole labour market'. By 1906, all the larger trade unions in Stuttgart had closed their own registries in favour of the municipal Labour Office. The unions of woodworkers, metalworkers, saddlers, paper-hangers, glaziers, bookbinders, brewers' operatives, millers, and factory workers compelled their unemployed members to register daily at the Labour Office as the condition of receiving out-of-work pay. ${ }^{132}$

At first, the combination of public labour exchange with the registration of the unemployed by the trade unions themselves seems to have been delicate, however. In Strasbourg as well as in Erlangen, Freiburg, and Mulhouse, municipal allowances according to the Ghent system were refused to certain individuals whom the trade unions had otherwise granted benefits to (in the case of strikes, or a sojourn elsewhere). Municipal authorities in these cities found a way to exclude such individuals from those who were 'genuinely' unemployed by monitoring the registry lists of the trade unions. While those unemployed were to be allowed a municipal subsidy based on their union benefits, they were now also required to register at the municipal labour exchange. This was considered an advance over the Ghent system, for:

the advantage of the Strasbourg institute above the system of the town of Ghent consists in the fact that one is not content any more with the control by trade unions alone, but that a system of control has been installed whereby unemployed receiving benefit from the municipality have to present themselves at certain hours, in case of suspicion even two or three times a day. ${ }^{133}$

\section{France, Belgium, the Netherlands, and the Scandinavian countries}

The German example of combining unemployment insurance and public labour exchanges under supervision of bipartite councils of employers

déclarations de chômage et de l'attribution des subventions.'

131 Whiteside, 'Unemployment Revisited', 45-49; Mansfield, 'Flying to the Moon', 27; see also Zimmermann, La constitution du chômage, 121-127.

132 Beveridge, Unemployment, 244-245.

133 Most, 'Die Handhabung der Kontrolle', 6. See also Zimmermann, La constitution du chômage, 128-131. 
and workers played an important role in the British debate on these issues, and went on to be adopted by many other European countries. ${ }^{134}$ However, at the large Conférence Internationale du Chômage, held in Paris on 18-21 September 1910, where the question of control of the unemployed receiving benefit was a major topic, it appeared that France was lagging behind. ${ }^{135}$ A 1905 law prescribing the establishment of municipal labour bureaux (not be confused with the bourses du travail mentioned earlier) in towns with populations over 10,000 was only followed by some. Control of the unemployed on benefits was still an exclusive affair of the trade unions. The French expert at the conference could only note as an oeuvre à faire to constitute employment agencies everywhere, combined with unemployment funds, to control the unemployed continuously by obliging them to present themselves at their bureaux. ${ }^{136}$ This proposal was realized in laws dating from 1910 and 1911, which required unemployed people receiving benefits to register at the labour exchanges. ${ }^{137}$

In the case of Belgium, the assessment at the Paris conference was mixed. As indicated above, several trade unions in Ghent had handed over the daily supervision of their out-of-work members to the municipal exchange. Other places in Belgium had followed the example of Ghent. However, there were still unions that required their unemployed members to register daily at the office of the society itself. At that time, daily visits to the Municipal Exchange were necessary only for those unemployed members of the unions who had handed over their registration. ${ }^{138}$

In the Netherlands, the Ghent system was introduced in several municipalities from 1906 onwards. At the 1910 Paris conference it was reported that it was 'in fact the associations themselves that most often verify the unemployed status of their members, generally by mandating that they present themselves daily at a set hour and place.'. ${ }^{139}$ Yet the majority of the municipal funds had reserved the right to control the statements of the associations. A certain number of funds insisted on the indemnified

134 On the influence of German ideas in these issues in Britain: Harris, Unemployment and Politics; in the Scandinavian countries: Edling, 'Regulating Unemployment the Continental Way'; in the Netherlands: Van Bekkum, Tussen Vraag en Aanbod, 166.

135 Rudischhauser and Zimmermann, 'Ö̈fentliche Arbeitsvermittlung"', 101-102; see on this conference also Topalov, Naissance du chômeur, 59-115. The initiator of the Ghent system on unemployment relief, Louis Varlez, was the driving force behind this conference: ibid., 69-71. 136 Fuster, 'L'Assurance contre le chômage', 15 .

137 Luciani, 'Logique du placement ouvrier', 16; King and Rothstein, 'Government Legitimacy', 294, 303 .

138 De Bruyne and De Clerck, 'Le contrôle des chômeurs', 14.

139 Methorst, 'La lutte contre le chômage', 40. 
unemployed workman presenting himself every day at the municipal labour exchange, but in a city like Amsterdam the two services were kept separate until 1915. In 1916 registration at public labour exchanges by unemployed on benefits became mandated by national law. ${ }^{140}$

In the Scandinavian countries, the situation was somewhat different. ${ }^{141}$ The Ghent system was introduced in Norway in 1906 and in Denmark in 1907. In these countries, union control of unemployment insurance facilitated the creation of union-administered placement services, with the same officials managing the unemployment fund and the union exchange. In Denmark, unions for skilled and semi-skilled workers even retained control of placement services until the end of the 196os. In such cases, trade unions took on the responsibility for administering work tests to their members seeking assistance. Municipal public exchanges were chiefly used by the unskilled and unorganized workforce. In Denmark there was only one public labour exchange before the First World War (in Copenhagen), while in 1914 there were already 100 in Sweden and 24 in Norway. ${ }^{142}$ In these countries, public exchanges were not connected to the administration of union-based unemployment insurance. In Norway, unions regulated placement and benefits under the Ghent system until 1936, at which time the union-controlled unemployment insurance system was changed to a compulsory government-administered one, and public exchanges were given responsibility for imposing work tests. In Sweden, there was no public unemployment insurance until 1935, when a union-controlled Ghent system was introduced, resulting in union control of the work test. Labour exchanges were given no role in administering means-tested benefits. For non-union members, these tasks became the responsibility of a separate government organization. ${ }^{143}$

\section{Conclusion: reorganizing labour markets from 'craft' to 'place'}

The overview provided in the present chapter makes it clear that trade union methods for registering unemployed members for the purposes of

140 Schrage and Nijhof, 'Een lange sisser en een late knal?', 35-36; Van Bekkum, Tussen Vraag en Aanbod, 222-223, 273; Bevaart and Veen, Den rechten man op de rechte plaats, 42, 50 .

141 King and Rothstein, 'Government Legitimacy', 294, 300-303. On the Danish situation in 1910: Soerensen, 'La question du chômage'; on Norway, see Ormestad, 'Le contrôle des chomeurs'; on Sweden: Huss, 'La question du chômage'.

142 Edling, 'Regulating Unemployment the Continental Way', 34.

143 On the specificity of the Swedish case, see also King and Rothstein, 'Institutional Choices'. 
intermediation and control were only gradually and unevenly incorporated into public labour exchanges. If we accept the proposition put forward above that craft unions were incorporated into public institutions of labour exchange and unemployment control to protect the unemployment benefits of their members in expanding industrial and casual labour markets, organizational and temporal variations in different countries could perhaps be explained by national variations in labour market developments. From this perspective it comes as no surprise that Britain developed the most centralized system because of its advanced industrial and casual labour markets, that France lagged behind because of the endurance of artisanal relations of production, and that Germany, with its mixed and diversified economy, developed municipal exchanges adapted to local and regional labour markets. The specific developments in Denmark and other Scandinavian countries, where trade unions managed to keep control for much longer than elsewhere in Europe, could perhaps be explained by late industrialization. These differences can also be related to the relative strength of political currents inside and outside the labour movement, however, such as reform liberalism in Britain, of which William Beveridge was such an eloquent representative, social democracy in Germany and Scandinavia, or the influence of syndicalism in France, the driving force behind the artisan bourses du travail, which in itself can also be explained by the preponderance of artisan labour.

Yet in the period prior to the First World War locally or nationally unified public institutions replaced the labour exchanges of individual trade unions in almost all European countries. In a short text, the French economist Jean Luciani has provided a penetrating analysis of this development, starting from the tension between a logique professionnelle and a logique locale (or spatiale) of labour market intermediation. ${ }^{144}$ Craft-controlled job placements were meant to protect the skilled professions by relegating outsiders to unorganized 'calling-around' or 'subcontracting' in finding work. In that way, a dual labour market was created. In the era of the ancien régime the contradiction between the local organization of the labour market by urban corporations and inter-urban labour mobility was resolved by craft-centred, but non-localized compagnonnages. The supra-local organization of labour market intermediation by the British trade unions with the help of 'vacant books' and 'houses of call' can be considered a British variant of this solution. The establishment of the bourses du travail in Paris and elsewhere in France is described by Luciani as an intermediary stage to reduce the tension between 
'craft' and 'place' while attempting to combine a professional with a local organization of job placement. The creation of Bureaux Municipaux de Placement after 1905 and Offices Départementaux de Placement after 1915, combined with a system of subsidized unemployment benefits, undermined the intermediary function of the union-dominated bourses du travail. And it signalled a definitive turn towards a spatial construction of the labour market.

The theme has been elaborated by Bénédicte Zimmermann in the German case of unemployment construction entre professions et territoires. In administering unemployment insurance, the two logics - professional and territorial - had to be reconciled. The communal subsidies in the Ghent system were meant only for the residents of specific municipal territories, whereas trade unions in that epoch were organized as professional or craft communities. Zimmermann writes about the logique professionnelle de qualification du chômage (the professional logic to be qualified as unemployed) as against the logique territoriale d'identification des chômeurs (the territorial logic to identify the unemployed). ${ }^{145}$ The identification of 'unemployed' union members and municipal inhabitants did not necessarily coincide: for the union they were colleagues - and potential competitors - out of work; for the municipality, they were residents entitled to a benefit. The way municipal authorities tried to incorporate union registration of unemployed members for their own purposes while at the same time restricting the union's criteria for allowing benefits (combining unemployment with travel or strike funds, as described above), illustrates how this tension could not be resolved without shifting the organization of the labour market from a professional to a spatial foundation.

The Ghent system and the corresponding institutionalization of unemployment control in centralized labour exchanges were implemented in order to organize a labour market hierarchy on a territorial basis. A spatial reconfiguration of labour market intermediation could make unemployment control more effective, as a German report averred in 1906, against the fragmentation of union-controlled labour exchanges:

Such a situation of fragmentation must considerably influence the performance of the labour exchange as an institution of unemployment control [...]. The unification and centralization of labour intermediation are a precondition for such control to be effective. ${ }^{146}$

145 Zimmermann, La constitution du chômage, 90, 114.

146 Kaiserliches Statistisches Amt, Die Versicherung gegen die Folgen der Arbeitslosigkeit, 2 , cited by Risch, 'Gewerkschaftseigene Arbeitslosenversicherung', ${ }^{16}$. 
In the longer term, the 'territorialization' of labour exchanges and the concomitant work tests were a prerequisite for extending unemployment insurance from the skilled and organized trades to other types of labour. From a somewhat different perspective, Malcolm Mansfield has analysed the British case. There, from an early stage, public labour exchanges were conceived as a national clearing system, as a 'spatial transformation' of the labour market associated with the rise of concepts of labour supply and unemployment as abstract categories. ${ }^{147}$ These concepts evolved from analyses of the growing unskilled casual labour markets, especially in London. To Beveridge, these appeared to be markets for unspecified ('abstract') labour without further qualification. Mansfield's research demonstrates that concepts of abstract, interchangeable labour were at the core of the idea that labour supply could be regulated by a 'catch-all' national network of labour exchanges.

Why, then, had trade unions been prepared to give up the intermediary functions for their members, and hand them over to public exchanges? The answer has to be found in the character of nineteenth-century trade unions as associations of skilled craftsmen. Union regulation of job placements and unemployment benefits were meant to enable members to uphold a standard wage rate and occupational status by excluding admission to others. Growing pressure from 'outsiders' in the labour market and intensified unemployment crises, such as that of 1908-1909, made it difficult to sustain this kind of protection. Urban and industrial development and related migration flows resulted in a larger and more fluctuating supply of labour. For the craft unions, the Ghent system was an attractive way to overcome these difficulties. As Zimmermann writes of the Strasbourg case:

As an elitist system of support to the unemployed, the principle of supplementing trade union benefits could be addressed only to workers who already had some social means: essentially these were skilled artisans, reflecting the exclusive implantation of Strasbourg trade unionism in traditional crafts. ${ }^{148}$

In this light it is not surprising that the system was first introduced in cities with diversified economic structures, where artisan industries dominated (in southern Germany, for instance), and not in areas of large industry (like 
the Ruhr or Saxony in Germany). ${ }^{149}$ The authorities were prepared to support the unions because their members - able to save money for an insurance premium - represented a stable and regular part of the workforce in a growing casual labour market. In the eyes of liberal reformers, the growth of casual labour had led to a 'disorganized labour market'. It tended to generalize 'underemployment' or 'irregular employment' and was considered a waste of productive labour power. ${ }^{150}$ In economic terms, trade union members were considered 'efficient' workers whose position had to be protected from unproductive (or 'inefficient') ones. The central objective of public labour exchanges was to distribute available work among a restricted group of workers. Controlling the unemployed's willingness and ability to work on a regular basis made the allocation of labour more selective. That way, the labour supply could be split into a 'fit' and an 'unfit' body of workers. The latter were then relegated to an 'external' market of informal and second-rate jobs, or poor relief. Put differently,

by regularising employment [the organisation of the labour market] would sift [the unemployable] out of the industrial world altogether [...]. The work lost by these men - the unemployables on the fringe of industry - would go to make up a reasonable subsistence for others. ${ }^{1{ }^{1}}$

149 Ibid., 127.

$15^{0}$ This is the central argument of Beveridge, Unemployment; on this issue, see also: Mansfield, 'Labour Exchanges'.

151 Beveridge, Unemployment, 215 . 


\title{
6 The transnational origins of Dutch miners' unionism
}

\author{
A case study in the nationalization of labour movements \\ $(1907-1926)$
}

\begin{abstract}
Several authors have argued that from the late nineteenth century labour markets became increasingly organized and regulated nationally, by national social security arrangements, collective agreements, systems of labour exchange, and migration control. As a consequence, members of the working classes began to consider themselves, and were considered, to be national citizens, and labour movements became nationalized. The First World War was a watershed in this process. In this chapter, I want to find out to what extent this development influenced attitudes of the two Dutch miners' unions, of which the one that was originally inter-confessional would become the most prominent. Until the First World War labour markets in the Limburg coal mining district in the deep south of the Netherlands and in the adjacent German Aachen district were fully integrated, and so were the nascent miners' unions. On the eve of the First World War the Dutch inter-confessional union even became a branch of the German Christliche Gewerkverein. This all changed after the war, until in 1922 all ties with the Germans were severed, and the union, soon to become officially Catholic, reoriented on the Dutch state and the Limburg region. This chapter describes the transnational origins of the miners' unions against the background of the cross-border labour market in the borderlands, and the effects of the territorialization of labour markets on the orientation of the unions after the First World War.
\end{abstract}

Keywords: cross-border labour markets, transnationalism, nationalization of labour movements, miners, confessional unionism, First World War, The Netherlands

Knotter, Ad, Transformations of Trade Unionism: Comparative and Transnational Perspectives on Workers Organizing in Europe and the United States, Eighteenth to Twenty-First Centuries. Amsterdam, Amsterdam University Press, 2018 DOI: 10.5117/9789463724715_CHo6 
Several authors have argued that in the twentieth century European states experienced a 'transformation of territoriality' through a process of 'nationalization.' ' Labour markets became increasingly organized and regulated nationally, by national social security arrangements, collective agreements, systems of labour exchange, and migration control. As a consequence, members of the working classes began to consider themselves, and to be considered, national citizens, and labour movements became nationalized. ${ }^{2}$ In this protracted and multi-form process, which started well before 1914, the First World War is generally considered a watershed. Two kind of developments stand out as particularly significant: the increased control of migration and monitoring of migrants to protect national labour markets, and the regulation of these markets through unemployment insurance organized and/or supported by the state. These two were in fact closely related: because welfare arrangements - of which unemployment insurance was one of the most important - became part of citizens' rights, the state acquired an interest in protecting the national labour market from uncontrolled immigration. Likewise, parts of the labour movement demanded protection of workers against the intrusion of competitors from abroad, as labour markets were now increasingly regulated nationally by collective agreements and welfare provisions. ${ }^{3}$

In the Netherlands, from 1918 onwards the state became more heavily involved in regulating migration and welfare arrangements such as unemployment insurance. ${ }^{4}$ Trade unions were incorporated into this system as the state began to support unemployment insurance schemes run by the unions themselves. In this chapter I will explore how this development influenced attitudes of the two Dutch miners' unions (one inter-confessional and the other social democratic). Before the First World War labour markets in the coalmining districts in the borderlands of Dutch South-Limburg and in the adjacent German Aachen area were fully integrated. As a consequence, both Dutch miners' unions had a transnational orientation. On the eve of the First World War the Dutch inter-confessional union (established in 1907) even became a branch of the German Gewerkverein christlicher Bergarbeiter.

1 Maier, 'Transformations of Territoriality'; idem, 'Consigning the Twentieth Century to History'; Noiriel, La tyrannie du national.

2 Van der Linden, 'The National Integration of European Working Classes'; repr. in idem, Transnational Labour History, 23-47. For a similar argument (partly referring to Van der Linden): Gallisot, 'La patrie des prolétaires'. For the Netherlands this process was already described in 1956 as the 'in-growth' of the trade union federation NVV by De Jong, Om de plaats van de arbeid.

3 Lucassen, 'The Great War'.

4 Ibid., 57-58. 
This was somewhat of an anomaly, as most Christian workers' movements in Europe in this period objected to workers' internationalism and cherished national and regional identities. ${ }^{5}$ The Dutch Christian miners' union fully developed a national and regional orientation only after the First World War. In 1922 all ties with the Germans were severed, and the union (soon to become officially Catholic) reoriented to the Dutch state and the Limburg region. In this chapter I describe the transnational origins of both miners' unions against the background of the cross-border labour market in these borderlands, and the effects of the territorialization of labour markets on the unions' attitudes after the First World War. It is based on a close reading of the two unions' (bi)weekly magazines: De Christelijke Mijnwerker and De Mijnwerker. ${ }^{6}$

Trade unionism arrived relatively late in the Dutch coal industry. ${ }^{7}$ The oldest miners' union, the Algemeene Bond van Christelijke Mijnwerkers in Nederland, commonly shortened to Christelijke Mijnwerkersbond (Christian Miners' Union, СMB), established in 1907, was a so-called inter-confessional union. It was modelled on the German Gewerkverein christlicher Bergarbeiter Deutschlands (dating from 1894), with a large membership in the Aachen mining district. ${ }^{8}$ At that time, there had already been some failed attempts at the formation of a non-confessional union by Dutch members of the German Verband der Bergarbeiter Deutschlands, returning to Limburg after working in Germany. This German union, generally known as Alte Verband, was established in 1889, and had a social democratic orientation. Only in 1909 could an Algemeene Nederlandsche Mijnwerkersbond (General Dutch Miners' Union, ANMB) be formed, with the support of both the Alte Verband and the Dutch national trade union federation, Nederlandsch Verbond van

5 Pasture, 'Anti-internationalisme'; idem, 'Introduction: Between Cross and Class', 45.

6 I use these short titles for convenience's sake, and to avoid confusion. De Christelijke Mijnwerker: Orgaan van de Algemeenen Bond van Christelijke Mijnwerkers in Nederland (appearing between 1911 and 1926) was preceded by De Mijnwerker: Orgaan voor het Limb. Kolenbekken (1907-1908); De Mijnwerker: Orgaan van den Algemeenen Bond van Kristelijke Mijnwerkers in Nederland (1909-1911); De Kristelijke Mijnwerker: Orgaan van den Algemeenen Bond van Kristelijke Mijnwerkers in Nederland (1911). De Mijnwerker was officially called De Mijnwerker: Orgaan van den Nederlandschen Mijnwerkersbond (1909-1925). These are available in digital form on www. shclimburg.nl/bibliotheek/mijnwerkerstijdschriften.

7 Overviews from completely different perspectives in Dieteren, Mens en mijn, and Kreukels, Mijnarbeid, 146-199.

8 Schneider, Die Christlichen Gewerkschaften, 55-74; Hiepel, Arbeiterkatholizismus. In 1900 a branch of the Christliche Gewerkverein was formed in the Aachen Wurmrevier. Between 1907 and 1910 (1 January) membership in the Wurm district grew from 1,785 to 3,465: Christelijke Mijnwerker, 12 July 1913: 'De Duitsche Christelijke Mijnwerkersbond'; 19July 1913: 'De 14e Algemeene Vergadering van den Duitschen Christelijken Mijnwerkersbond, gehouden te Aken van 6-9 Juli'. 
Vakvereenigingen (NVV). As in the Aachen region, the indigenous population in the Limburg mining district were predominantly Catholic. A growing preponderance of native Limburg miners in the labour force in the $1930 \mathrm{~s}$ enabled the Catholic successor (from 1926) of the inter-confessional смв to definitively surpass the ANMB. Well into the 1920s, however, the two unions competed vigorously for the support of the Limburg miners.

\section{Cross-border labour market integration before the First World War}

The late arrival of trade unionism can be explained by the small scale of coal mining in the Netherlands during the nineteenth century. It was only around 1900 that expansion started with the opening of new mines, at first privately owned, of which the Oranje Nassau Mijnen in Heerlen was the most important. The company was established in 1893 by the German mining entrepreneur Friedrich Honingmann; in 1908 it was bought by the French steel magnates De Wendel. ${ }^{9}$ The Oranje Nassau Mijnen was the largest private mining company in the Netherlands, with four pits in and around Heerlen. Smaller private mines were the Société Anonyme des Charbonnages Néerlandais Willem et Sophia at Spekholzerheide (a Belgian company established in 1898 and producing coal since 1902), and the Société des Charbonnages Réunis Laura et Vereeniging SA at Eygelshoven (founded in 1898 by a Belgian colonial entrepreneur and the German Eschweiler Bergwerkverein, and producing coal since 1907). In 1902 the Dutch state started its own mining company, Staatsmijnen. It opened new mines in villages around Heerlen, named after members of the royal family: 'Wilhelmina' in Terwinselen (1909), 'Emma' in Hoensbroek (1913), 'Hendrik' in Brunssum (1917), and 'Maurits' in Geleen (1925).

In the nineteenth century, before twentieth-century expansion started, Dutch coal mining was restricted to only one mine, the Domaniale Mijn, in the mining town of Kerkrade on the German border near Aachen. Geologically, socially, and culturally, Kerkrade mining was part of the Aachen mining district, which had a long history of coal mining dating back to medieval times. ${ }^{10}$ In the nineteenth and the early twentieth centuries, Dutch miners from Kerkrade and the surrounding villages on the Dutch side of the border regularly and habitually went to work in the Aachen mines on the other 
side, just as German miners crossed the border to work in Kerkrade. In 1889 Kerkrade housed 1,162 miners, but the Domaniale Mijn employed only 400. In 1899, 893 Kerkrade miners were counted commuting daily to the Aachen mines; in 1912 their numbers were estimated at 1,100, and in 1914 at 1,700. ${ }^{11}$ An analysis of a sample of miners in the Domaniale Mijn between 1907 and 1912 showed that 18.6 per cent were born in the Aachen district; most of them lived in nearby Kohlscheid and were daily commuters. Another 21.3 per cent were born in other parts of Germany, mainly in the Ruhr area, but it is likely that they had previously moved to the Aachen district. Mobility between the mines on both sides of the border was quite common. Of the miners employed in the Domaniale Mijn who were born in the Netherlands (46.8 per cent) 16 per cent had worked in at least one German mine in the Aachen district before moving to the Domaniale; 5 per cent had also worked in a mine in the Ruhr area. ${ }^{12}$

Dutch-German labour market integration was facilitated by the free and abundant circulation of German currency in the Dutch mining district. Wages earned in Germany could easily be spent in the Netherlands. In Kerkrade in 1900 around 4,00o marks circulated each day. Because of the scarcity of Dutch money, the Dutch mines even paid wages in German currency until 1909. After that year, the miners still preferred to use German money: as soon as they had received their wages in guilders they changed it into marks. ${ }^{13}$ Dutch cross-border commuters, who were paid in German money, brought thousands of marks into circulation. ${ }^{14}$ The First World War meant an end to monetary integration. In 1914 some employers still continued to pay wages in German currency, but as a consequence of the outbreak of the war this was finally stopped.

The persistence of cross-border commuting in the first decade of the twentieth century is remarkable. At that time the expansion of the Dutch mining district north-west of Kerkrade, around the booming mining town of Heerlen, was in full swing, developing an urgent need for experienced miners. That cross-border commuters did not turn their daily journey the other way around to travel to the Heerlen mines is a clear sign of the cross-border

11 Langeweg, Mijnbouw en arbeidsmarkt, 92-93; Klank, 'Secondary Labour Force', 136; Christelijke Mijnwerker, 28 November 1914: 'De muntkwestie'.

12 Korres, 'Historische interacties in de Euregio Maas-Rijn', 21-23.

13 Mooij, 'Guldens versus franken en thalers', 25-28.

14 Ibid.; Christelijke Mijnwerker, 28 November and 12 December 1914: 'De Muntkwestie'; De Mijnwerker, 2 January 1915: 'Neem geen vreemd geld meer in betalingen'; 23 January 1915: 'Verslag der besturenconferentie op Zondag 17 Januari 1915'; 15 May 1915: 'Verslag over het tijdvak 1 Januari 1913 tot en met 31 December 1914'. 
integration of the Kerkrade and Aachen mining labour markets, and the continuing segregation from the Heerlen mining district. Cross-border integration had been reinforced by tradition and social insurance rights. ${ }^{15}$ A 1908 report wrote about an 'old miners' tribe' in the border area that continued working abroad. Asked why he commuted two hours to the German mine Nordstern, while he could reach the new inland Dutch mines in half an hour, a 43-year-old Dutch miner answered that he was deterred from leaving because his pension rights, built up in 27 years of working in Germany, could not be transferred. ${ }^{16}$

The new mines around Heerlen encountered several difficulties in recruiting skilled miners. There was no tradition of mining in this area, and for experienced Kerkrade miners they had to compete with the nearby German district. The Heerlen mines tried to overcome these difficulties by recruiting migrants from outside the Limburg district, both from other parts of the Netherlands and from abroad. The number of migrant workers born outside the Netherlands in all Limburg mines grew from 429 in 1905 to 2,500 in 1913 (that is from 17 to 24 per cent). These were mainly Germans, Slovenes, and Poles, arriving from the Ruhr or the Aachen district. But there were also many Dutchmen from other parts of the Netherlands arriving in Limburg via German mines. In 1912, 6,111 new miners were recruited for underground labour in the Netherlands; 4,129 (68 per cent) had been employed in a mine before, 2,098 (51 per cent) of them in Germany. ${ }^{17}$

\section{Origins and early development of the Christelijke Mijnwerkersbond}

Since 1905 the Christliche Gewerkverein had been sending propagandists across the border to unionize Dutch miners and to prevent them from working in Germany below German wage standards. In 1905 and 1906 at least 44 meetings of the Gewerkverein were held in the Dutch mining district. Local branches of the German union sprang up in Kerkrade and mining villages on the border. ${ }^{18}$ In 1907, 345 of the 900 miners from Kerkrade and surroundings working in Germany were reported to be organized in the

15 Langeweg, Mijnbouw en arbeidsmarkt, 96-97.

16 Christelijke Mijnwerker, 15 February 1908: 'Naar aanleiding van de Maastrichtse Petitie'; 1 March 1908: 'Knappschaftskassen'; De Mijnwerker, 26 August 1911: 'Uittreksel jaarverslag hfd. Ing. der mijnen 1910'.

17 Christelijke Mijnwerker, 13 September 1913: 'De Limburgsche Mijnindustrie in 't jaar 1912'.

18 Dieteren, Mens en mijn, 31. 
Christliche Gewerkverein, 25-30 in the Alte Verband. ${ }^{19}$ This union drive was boosted by the return from Germany of Dutch miners who had been active in the Christliche Gewerkverein, but had been expelled after the German miners' strike of $1905 .{ }^{20}$ They campaigned for an inter-confessional trade union for Dutch miners working in Limburg, and even started to set up branches themselves. ${ }^{21}$

By unionizing Dutch miners in this way the German inter-confessional trade union competed with the existing Catholic federation of local miners' associations in Limburg, the Centrale Bond van Roomsch-Katholieke Mijnwerkersverenigingen. This was not a trade union but an association to promote a Catholic life style, set up by the higher clergy and approved by the bishop of Roermond, the diocese in which the mining district was situated. ${ }^{22}$ In 1906 it had a membership of only 323. The bishop initially opposed the foundation of an inter-confessional trade union on the German model, but the propaganda and growing popularity of the Christliche Gewerkverein put pressure on the clergy. In the end the bishop had to accept the foundation of an inter-confessional miners' union in the Limburg diocese, not as a branch of the German one as was originally intended, but as a separate union. Pressure from miners to follow the German example was decisive:

It was obvious that Catholic miners looking for an example to unionize felt attracted to the Christlichen Gewerkverein, the more so because many of their comrades working at German mines are members [of this union], or they [themselves] had been members before, and remained members once they returned to the Dutch mines. ${ }^{23}$

On 25 October 1907 it was decided by the Centrale Bond van RoomschKatholieke Mijnwerkersverenigingen to establish the aforementioned Christelijke Mijnwerkersbond (from 1 January 1908) as a trade union alongside the Catholic Centrale Bond, which would now function as a

19 Christelijke Mijnwerker, 9 May 1907: 'Nederlandsche arbeiders op Duitsche mijnen'; 21 June 1907: 'Zij komen!'

20 Among whom was Chris Zielemans, later to become the first president of the Christelijke Mijnwerkersbond. This story is told ibid., 4 September 1909: 'Bij hoog en laag'.

21 Ibid., 1 March 1907: 'Uit de afdeelingen: Spekholzerheide'; 15 March 1907: 'Uit de afdeelingen: Ubach-over-Worms'; 30 March 1907: 'Vakbeweging'; 9 May 1907: 'RK Mijnwerkersvereeniging St. Leonardus [Kerkrade]'; 23 May 1907: 'Uit de afdeelingen: RK Mijnwerkersbond St. Catharina, Kerkrade'.

22 Dieteren, Mens en mijn, 20-27; Kreukels, Mijnarbeid, 146-151.

23 Christelijke Mijnwerker, 27 September 1907: 'Een belangrijke kwestie'. 
separate so-called standsorganisatie (in German, Standesorganisation, perhaps best described as a religious professional association) to promote Catholicism among the miners. In this way the German two-tiered structure of inter-confessional trade unions and Catholic professional organizations was copied in the Limburg mining district (as were debates about this issue). ${ }^{24}$ The German inspiration was made clear by a prominent Catholic union leader:

Because of their continual communication with the Germans our miners have become like their neighbours in doing and thinking, in morals and customs. They are born, so to say, with a preference for inter-confessional trade unions. If our Catholic miners' federation had ignored this, and had not been reformed according to the spirit of its members, then another union, in the German mould, would have been established; then secession and division would have weakened the power needed in our emerging coal industry. ${ }^{25}$

During 1908 the new organization was promoted in meetings throughout the mining district, invoking the German example, also by speakers of the German Christliche Gewerkverein itself, to reform existing local Catholic associations into branches of the Christelijke Mijnwerkersbond, or to set up new branches. ${ }^{26}$ Cooperation with the Gewerkverein was deemed necessary against 'international capital'. ${ }^{27}$ The Dutch union often appealed to its German sister organization to assist with experts and speakers at internal and propaganda meetings. ${ }^{28}$ Members of the Christliche Gewerkverein attended these meetings as well. ${ }^{29}$ In 1909 a Gegenseitigkeitsvertrag between both unions was signed, regulating the conditions of membership for crossborder migrants. ${ }^{30}$ The German union was allowed to organize commuting

24 See on this so-called Gewerkschaftsstreit: Schneider, Die Christlichen Gewerkschaften, 172-211; on its repercussions in the Netherlands: Koppenjan, 'Interconfessionalisme en verzuiling', and Kreukels, Mijnarbeid, 160-173.

25 Cited by Dieteren, Mens en mijn, 34.

26 References throughout Christelijke Mijnwerker, 1908.

27 Christelijke Mijnwerker, 28 March 1908: 'Uit de betaalplaatsen: Propaganda-vergadering Heerlen'.

28 E.g.: ibid., 5 December 1908: 'Ter overweging'.

29 For instance: ibid., 9 April 1910: 'Uit de betaalplaatsen' (Bocholtz); 3, 17, and 24 December 1910: 'Uit de betaalplaatsen' (Bleyerheide).

30 Ibid., 12 June 1909: 'Een congres'; 17 July 1909: 'Algemeene Vergadering van den Duitschen Christelijken Gewerkverein te Saarbrücken'. 
Dutch miners living in Limburg and working in Germany. ${ }^{31}$ Therefore, the Christliche Gerwerkverein still had its own so-called Zahlstellen (branches) in localities at the Limburg side of the border, such as Kerkrade, Bleyerheide, and Chèvremont. ${ }^{32}$

In December 1908, 969 Limburg miners belonged to the Christelijke Mijnwerkersbond out of a total of 5,075 employed in the district as a whole. ${ }^{33}$ In 1909 this number suddenly rose to about 3,000, to fall back again to 1,060 by the end of that year. The reason was that in January 1909 miners were mobilized in a struggle with the employers about new employment regulations in the (private) mining industry (Staatsmijnen was not included). ${ }^{34}$ Miners flocked into meetings and into the union to express their opposition. ${ }^{35}$ When a compromise was reached by members of the Limburg elite (clergy and nobility), acting on behalf of the union in a socalled Eereraad (Council of Honour), many members were disappointed about their behaviour, which had sidelined the membership, and about the results. ${ }^{36}$ Years after the event, its impact can be traced in discussions in the union's paper Christelijke Mijnwerker. ${ }^{37}$ The unrest not only led to an exodus of newly recruited members, but also provided fertile ground for the formation of a new union with a social democratic orientation.$^{38}$ Looking back in 1910, a Christian union leader stated: 'The movement [against the new regulations] gave some unsatisfied "reds" cause for counter-propaganda, and soon the socialists took advantage of this opportunity to establish a new union under the mask of neutrality.' 39 deringen' (Chèvremont); 13 May 1911: 'Uit de betaalplaatsen' (Chèvremont, Kerkrade).

33 Dieteren, Mens en mijn, 53; Langeweg, Mijnbouw en arbeidsmarkt, 266-267.

34 A detailed account in Kreukels, Mijnarbeid, 202-210.

35 See also the reports on the events in Christelijke Mijnwerker, January and February 1909.

36 Among its members were Mgr. W.H. Nolens, Jhr. Ch. Ruys de Beerenbrouck, Jhr. L. Van der Maessen de Sombreff. Reports of members criticizing this Eereraad in Christelijke Mijnwerker, 29 May 1909: 'Uit de betaalplaatsen', 5 June 1909: 'Wat heeft de Christ. Mijnwerkers Bond reeds gedaan voor de leden?', 12 June 1909: 'Uit de betaalplaatsen'. The Eereraad was also targeted by social democratic propagandists: Christelijke Mijnwerker, 3 July 19o9: 'Algemeene Nederlandsche Mijnwerkersbond'; 31 July 1909: 'Het masker afgelegd'; 6 November 19o9: 'Christelijke en Socialistische Mijnwerkersbond'.

37 For instance: Christelijke Mijnwerker, 17 September 1910: 'Uit de betaalplaatsen'; 29 October 1910: 'Uit de betaalplaatsen'; 5 August 1911: 'Alweer eene nieuwe afdeeling'.

38 Kreukels, Mijnarbeid, 174, 209; Social democratic propagandists were reported and warned against in the Christelijke Mijnwerker from February 1909.

39 Ibid., 17 September 1910: 'Uit de betaalplaatsen'. 


\section{Foundation of the Algemeene Nederlandsche Mijnwerkersbond (ANMB)}

Attempts to establish a non-confessional miners' union by Dutch members of the Alte Verband, returning or expelled from Germany, are reported from 1901, 1903, 1905, and 1906. The Alte Verband itself was present in the Limburg mining district with at least six Zahlstellen. ${ }^{40}$ On 22 August 1909, some 50 members of this German union, both Dutch and German miners, founded the Algemeene Nederlandsche Mijnwerkersbond. ${ }^{41}$ Later it was even claimed that 'the Dutch union was a child of the German organization'. ${ }^{42}$ Speakers and representatives of the German union from the Wurmrevier, just across the border, attended meetings and debates. In this way disputes between the German Christian union and the Alte Verband were transplanted to the Limburg mining district.

Although both were imported from Germany, the Christian union tried to present the socialist union as a Fremdkörper, a danger imported by strangers:

Limburg is already a place of attraction for foreign workmen. From all countries and areas workpeople arrive, and with them members of the red proletariat, amplifying the few red spots already present, and strengthening the still weak membership of the reds. Insidiously social democracy starts its work, as is proven by the Neutral miners' union. ${ }^{43}$

The ANMB soon grew, reaching about 700 members in 1910, but its membership then stagnated. It recruited some former members of the Christian union, ${ }^{44}$ but most of them were migrants, either from the Netherlands outside Limburg or from Germany. ${ }^{45}$ The Christian union contrasted the migrant origin of the members of the ANMB ('Most of them Germans, who have written on their standards: "Wand'ren, ach Wand'ren") to 'our Limburg

40 Wöltgens, Mislukte doorbraak, 8; see also Christelijke Mijnwerker, 13 November 19o9: 'Christelijke en Socialistische Mijnwerkersbond'; 25 May 1912: 'Gladweg gelogen'; De Mijnwerker, 7 July 1923: 'Het 10-jarig bestaan van de Afdeeling Hoensbroek'.

41 Kreukels, Mijnarbeid, 174. Its constitution was drafted in both Dutch and German. German members received the Alte Verband's Bergarbeiterzeitung, Dutch members ANMB's magazine De Mijnwerker: Christelijke Mijnwerker, 18 September and 9 October 19o9: 'Christelijke en socialistische mijnwerkersbond'.

42 De Mijnwerker, 29 July 1911: 'Onze jaarvergadering: een broedergroet'.

43 Christelijke Mijnwerker, 13 November 1909: 'Limburg in gevaar'.

44 Ibid., 29 January 1910: 'Uit de betaalplaatsen'; 18 February 1911: 'Waarom gaan we zoo langzaam vooruit?'

45 Ibid.; Kreukels, Mijnarbeid, 175. 
miners, who from early age have been working in the mines, and stepped in the footsteps of their fathers, so to say', ${ }^{46}$ clearly referring to the old Kerkrade mining population, among whom the Christian union had originated and where it found its strongest support. In its turn, the ANMB complained that the Christian union tried to raise suspicion about its German members. ${ }^{47}$

The German contingent in the ANMB was quite large: in 1910 it was reported to be 300 (of 700). ${ }^{8}$ To inform German members, its weekly De Mijnwerker regularly published articles in German; there were even proposals to publish half of it in German, because 'part of our membership cannot read our magazine', and therefore 'remains too much attached to the German movement'. ${ }^{49}$ German articles continued to be published until November 1914, when it no longer made sense, as the majority of the German members were called up for military service in the war or had returned to Germany for other reasons. In 1910, the union issued a call to incoming Germans to join the Dutch union..$^{50}$ Some of the German militants of the union were expelled by local authorities, however. ${ }^{51}$ In 1911 a judicial bureau (Rechtsauskunftstelle) was established in Kerkrade, to inform 'our German comrades and those Dutch comrades who had worked in Germany' about issues such as insurance and pension rights..$^{2} \mathrm{~A}$ sign of the German presence in the union's membership is the excuse made by a female speaker from Zaandam (near Amsterdam) at a festive meeting of the Arbeiter Volksverein Heerlen in 1913: as she could not make her speech in German, she would try to speak Dutch as clearly and slowly as possible. A Dutch union leader urged German members 'to fight beside the Dutch members. You, Germans, are used to fighting, as you have showed many times already. 53

The АNмв also recruited miners originating from other parts of the Netherlands who had acquired their skills in the Ruhr area, and had migrated from there to Limburg, where demand for these skills was great. The mobility

46 Christelijke Mijnwerker, 30 July 1910: 'Het pensioenfonds der Staatsmijnen'.

47 De Mijnwerker, 23 April 1910: 'Uit de Afdeelingen'.

48 Ibid., 15 January 1910: 'De Secretaris-Generaal'. See also Bergarbeiter-Zeitung, 30 April 1910: 'Aus dem holländischen Bergbaurevier', and 12 August 1911: 'Generalverammlung des holländischen Bergarbeiterverbandes'.

49 De Mijnwerker, 7 May 1910: 'Beschrijvingsbrief voor de eerste Algemeene Vergadering van den Nederlandschen Mijnwerkersbond op zondag 22 mei 1910'.

50 Ibid., 18 June 1910: 'Uit de Afdeelingen'.

$5^{1}$ Ibid., 18 June 1910: 'De uitzetting van Schijmanski in de Tweede Kamer'; 31 January 1914: 'De waarheid boven alles'; 'Een cultuurbeeld uit de mijnstreek'.

52 Ibid., 9 March 1912: 'Bericht unserer Rechtsauskunftstelle in Kerkrade'; 20 April 1912: 'Jaarverslag 1911'; 5 October 1912: 'Rechtsschutzbureau te Kerkrade'.

53 Ibid., 2 August 1913: 'Het Maandagfeest der Heerlensche Volksverein'. 
Figure 6.1 Postcard issued by the German miners' union Alte Verband, date unknown

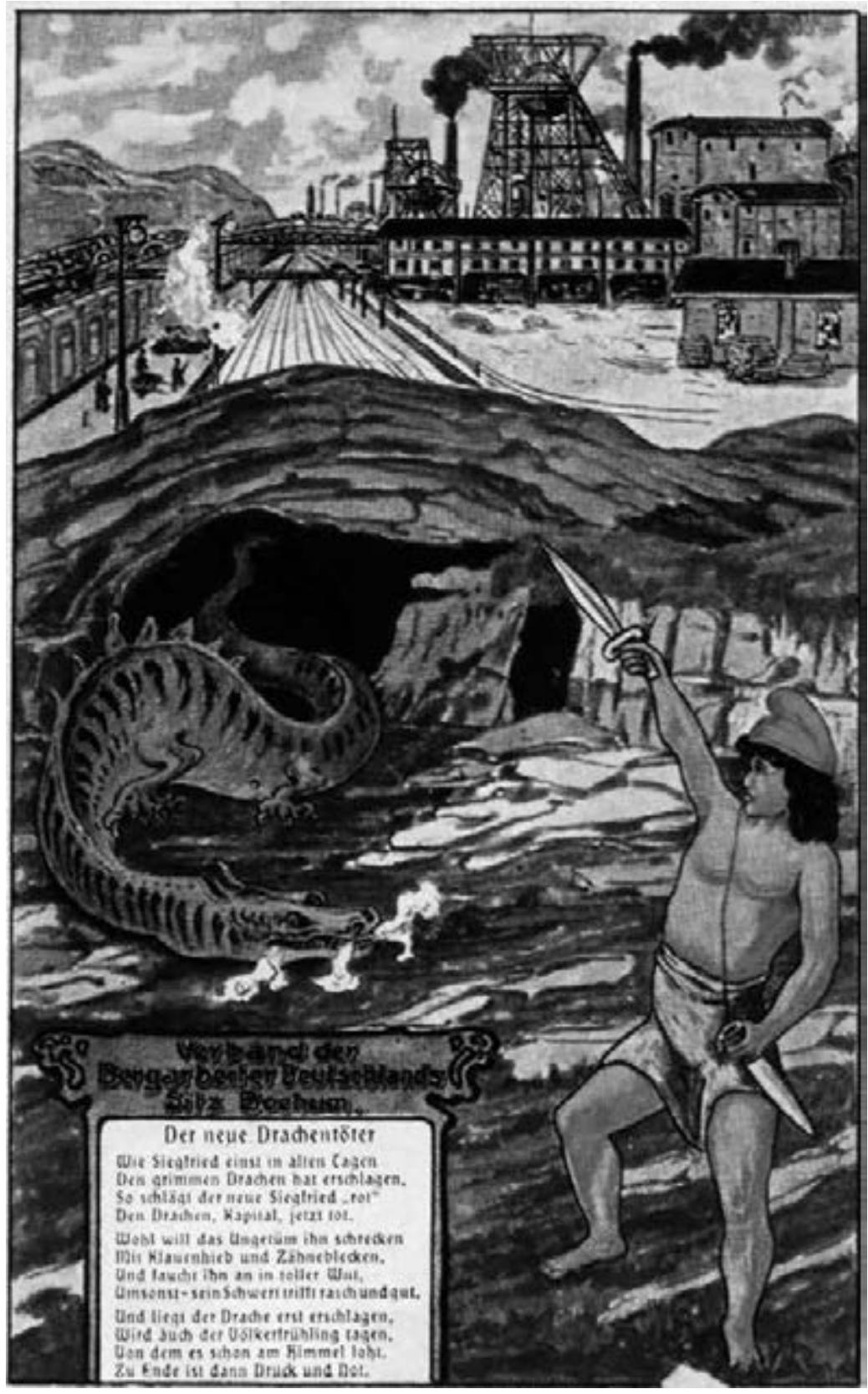

From: Wolfgang Jäger and Klaus Tenfelde, Bildgeschichte der deutschen Bergarbeiterbewegung (Munich, 1989), 72 
in this group was extraordinarily high, however; therefore, it was difficult to build a stable membership. ${ }^{54}$ In 1910 , for instance, the union registered 1,152 members, but had to cancel 400 of them (hence a net membership of 70o), 'who did not like working in the Dutch mines, where conditions are much worse that in Germany, and therefore started to "auswandern" [emigrate] again.'55 In the following years mobility did not subside..$^{5}$ Most of these mobile miners had at first been recruited in other parts of the Netherlands ('Holland' from a Limburg perspective) by the Dutch labour exchange in Oberhausen to work in Germany, but in 1914 we are informed that a core of steady members had been formed, also of native Limburgers. More propaganda directed at the Limburg population was deemed necessary. ${ }^{57}$ There can hardly be any doubt, however, that the ANMB found its largest following among miners who were born outside Limburg. In 1912 the Christelijke Mijnwerker observed:

Every Limburger in the mining district knows of course that not even 2 per cent of the membership of the socialist union are Limburgers [...] When the socialists hold meetings, or whatever, one can see all kinds of people, but no Limburgers. ${ }^{8}$

\section{Membership crisis in the Смв and its incorporation into the Christliche Gewerkverein (1914)}

In the years before the First World War, in addition to, firstly, the longestablished mining population living in Kerkrade and surroundings, secondly, the migrants and commuters from Germany, and, thirdly, the migratory workers from 'Holland', a fourth category of miners was recruited by the expanding mining industry from the rural population in the western and southern part of South-Limburg, both inside and

54 Kreukels, Mijnarbeid, 175 .

55 De Mijnwerker, 1 July 2011: 'Jaarverslag van den Ned. Mijnwerkersbond over 1910'.

56 Ibid., 20 April 1912: 'Jaarverslag 1911'; 16 November 1912: 'Gebrek aan arbeiders in de Duitsche mijnindustrie'; 22 February 1913: 'Lokvogels', 24 May 1913: 'Waarschuwing tegen werfagenten'; 25 January 1913: 'Ledenstatistiek'; 22 November 1913: 'Onze ledenstatistiek'; 11 July 1914: 'Ledenstatistiek'; 14 August 1915: 'Een waarschuwing'; 21 August: 'Gebrek aan geschoolde werkkrachten'. 57 Ibid., 11 July 1914: 'Ledenstatistiek'.

$5^{8}$ Christelijke Mijnwerker, 12 October 1912: 'Het oude refrein'; see also 18 February 1911: 'Waarom gaan wij zo langzaam vooruit?': the ANMB 'recruits among immigrants who had already become socialists in Holland, together with a few foreigners who sought refuge here [...]; indigenous miners adhering to the 'neutrals' can be counted on the fingers of two hands....' 
outside the mining district. These were often part-time peasants and agricultural labourers; only the younger generation became full-time miners. ${ }^{59}$ Figures (see Appendix 6.1) from the 1909 census about miners living in the villages around Sittard and in the Meuse Valley in the west, and in the so-called Heuvelland (south-east of Maastricht) in the south, as well as workmen's cheap weekly train tickets in 1911, show to what extent the South-Limburg countryside had become involved in supplying labour to the mines. We have figures of local membership of the Christian union only from late 1915, and these show that by this stage the union had made some headway in the villages around Sittard, but also that there were still many blank spots in rural areas. Efforts to organize these rural Limburg miners starting in 1911, and supported by the local clergy, ${ }^{60}$ had not been very successful:

Travelling by train between Sittard [in the west] and Herzogenrath [to the east, just across the German border], you will be amazed at the large number of workers leaving for the mines from Sittard, Geleen, Stein, Elsloo, Spaubeek, Schinnen, Nuth, and all the other surrounding villages [...]. A few years ago most of these workers were agricultural labourers; now they have turned into miners. These people did not have any contact with men of our union before, so it is self-evident that it takes a lot of effort to win them over to organize. ${ }^{61}$

In 1915 still, a recently appointed union secretary observed that most miners with a rural background did not consider mining a permanent job, and that their local chauvinism hindered union solidarity with miners from other parts of the area ${ }^{62}$ Unionizing former rural workers was considered the greatest challenge for the union: 'Workers, who perhaps were still labouring in the fields yesterday, having never heard of organization, have to be brought into our union. ${ }^{63}$

59 Rutten, 'Het thuisfront van de mijnwerker', 390-392.

6o Christelijke Mijnwerker, 26 August 1911: 'Een flinke oogst': ‘Each Sunday clergymen and priests roam with us through the mining district to urge people to organize.'

61 Ibid., 16 December 1911: 'Spaubeek'; see also 28 January 1911: 'Waarom gaan we zo langzaam vooruit?'; 24 June 1911: 'Onze tweede vrijgestelde'; 29 June 1912: 'Ons finantieel jaarverslag'; Dieteren, Mens en mijn, 85-90, 97-98. For the location of these villages see appendix 6.1.

62 Cited by Kreukels, Mijnarbeid, 180.

63 Christelijke Mijnwerker, 10 June 1916: 'Wij moeten doorwerken'. 
Table 6.1 shows that at that time the Christian union also had great difficulties penetrating the booming Heerlen area, ${ }^{64}$ in contrast to the ANMB, which, as a result of the immigrant background of most of its members, found its strongest support there. For the ANMB there are figures for gross monthly membership growth in 1913, and their local distribution show a clear preponderance by the Heerlen district. Membership figures for the ANMB from late 1916 show a second stronghold in Maastricht, but this was a recent development, as is clear from a comparison with 1913. In 1915 the CMB still very much relied on its original base in the Kerkrade region: 56 per cent of its membership were living there, as against 46 per cent of the total number of miners in 1909 .

Table 6.1 Membership of the сMB in 1915 (31 December) and the ANMB in 1916 (31 December), and gross monthly membership growth of the ANMB in 1913 in the sub-districts of the Limburg mining district, compared to the number of miners living there (density) in 1909

\begin{tabular}{|c|c|c|c|c|c|c|}
\hline & & & & & Densit & \\
\hline & $\begin{array}{l}\text { СMB } \\
1915\end{array}$ & $\begin{array}{l}\text { ANMB } \\
1913\end{array}$ & $\begin{array}{l}\text { ANMB } \\
1916 \\
\text { (mem- } \\
\text { bership } \\
\text { growth) }\end{array}$ & $\begin{array}{l}\text { Miners } \\
1909\end{array}$ & $\begin{array}{l}\text { СMB } \\
1915\end{array}$ & $\begin{array}{l}\text { ANMB } \\
1916\end{array}$ \\
\hline $\begin{array}{l}\text { 'Old' mining district (Kerk- } \\
\text { rade and surroundings) }\end{array}$ & $\begin{array}{r}637 \\
(56 \%)\end{array}$ & $\begin{array}{r}190 \\
(30 \%)\end{array}$ & $\begin{array}{r}277 \\
(25 \%)\end{array}$ & $\begin{array}{l}3,049 \\
(46 \%)\end{array}$ & $21 \%$ & $9 \%$ \\
\hline $\begin{array}{l}\text { 'New' mining district (Heerlen } \\
\text { and surroundings) }\end{array}$ & $\begin{array}{r}273 \\
(24 \%)\end{array}$ & $\begin{array}{r}335 \\
(53 \%)\end{array}$ & $\begin{array}{r}493 \\
(45 \%)\end{array}$ & $\begin{array}{l}2,774 \\
(42 \%)\end{array}$ & $10 \%$ & $18 \%$ \\
\hline Heerlen & 63 & 212 & 246 & 1,343 & & \\
\hline Other locations & 210 & 123 & 247 & 1,431 & & \\
\hline $\begin{array}{l}\text { Sittard and surroundings/ } \\
\text { Meuse Valley }\end{array}$ & $\begin{array}{r}179 \\
(16 \%)\end{array}$ & $\begin{array}{r}18 \\
(3 \%)\end{array}$ & $\begin{array}{r}25 \\
(2 \%)\end{array}$ & $\begin{array}{r}531 \\
(8 \%)\end{array}$ & $34 \%$ & $5 \%$ \\
\hline $\begin{array}{l}\text { Maastricht and surroundings } \\
\text { ('Heuvelland') }\end{array}$ & $\begin{array}{r}47 \\
(4 \%)\end{array}$ & $\begin{array}{r}91 \\
(14 \%)\end{array}$ & $\begin{array}{r}269 \\
(24 \%)\end{array}$ & $\begin{array}{r}250 \\
(4 \%)\end{array}$ & & \\
\hline Maastricht/Heer & 22 & 72 & 269 & 8 & & \\
\hline Villages & 25 & 19 & - & 242 & & \\
\hline Roermond & - & & $40(4 \%)$ & & & \\
\hline Total & 1,136 & 634 & 1,104 & 6,604 & & \\
\hline
\end{tabular}

* Members in military service excluded.

Sources: See Appendix 6.1

64 Difficulties in sustaining the Heerlen branch were reported ibid., and 9 and 19 September 1916: 'Vergaderingen' and 'Sociale werkloosheid te Heerlerheide'. 
Figure 6.2 Map of the sub-districts of the South-Limburg mining region and the location of the mines

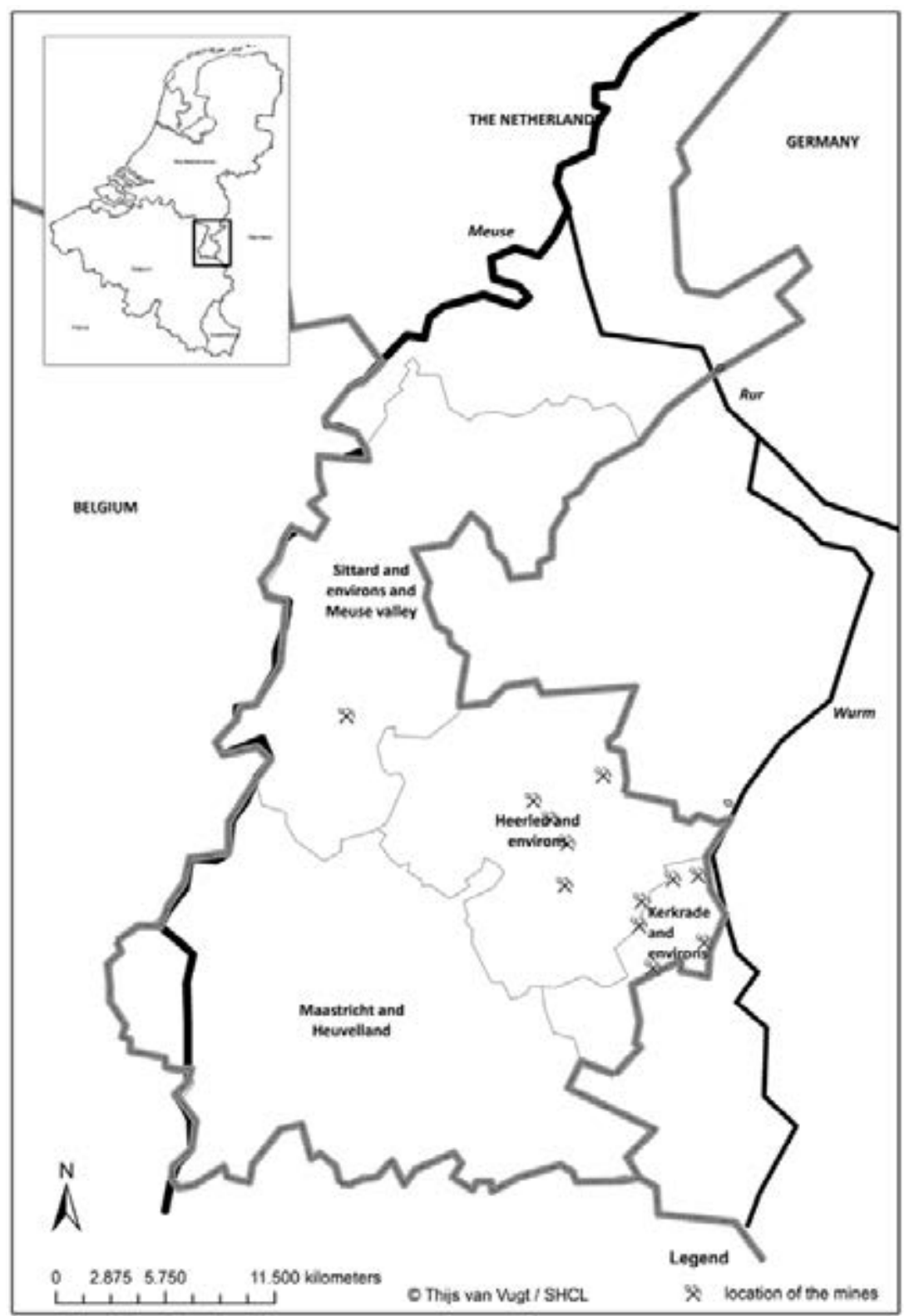


In 1910, however, precisely in its Kerkrade stronghold, a conflict arose with a significant minority within the Christion union, led by one of its former presidents Joh. Ankoné. ${ }^{65}$ The conflict cannot be separated from political dissidence in the Catholic party in Kerkrade at that time, but in union affairs one of the main issues concerned proposals for a general pension fund by Staatsmijnen: while the Christian union wanted a Bismarckian system, in which employers and workers would both pay a premium, the ANMB demanded a fund fully paid for by the employers, and on this issue the Kerkrade opposition sided with the socialists. ${ }^{66}$ The debate would haunt the Christian union into the first half of the 1920s, when the socialist union gained a majority for these demands in elections for workers' representatives in the recently established general miners' pension fund. In 1911, after fierce debates and unrest among the miners, the conflict resulted in a split and the formation of a new union in Kerkrade, the Algemeene Nederlandse Mijnwerkersbond 'Recht en Plicht' (General Dutch Miners' Union 'Right and Duty'). It is not clear how many members of the смв sided with Recht en Plicht, but an indication of its popularity can be gained from the election of the workers' committee at State Mine 'Wilhelmina' in November 1911: СмB: 503; ANмB: 267; Recht en Plicht: 256 votes. ${ }^{67}$ Recht en Plicht was still mentioned as a separate union in 1915, but a year later Ankoné and his followers returned to the Christian union. ${ }^{68}$

The breakaway union Recht en Plicht in the Christian union's stronghold around Kerkrade added to the lack of success in the new mining district around Heerlen and among rural miners in the villages to the west and south. It plunged the Christian union into a membership crisis from 1911 onwards, its membership reaching an all-time low of 500 at the end of 1913 (see Figure 6.3). It was this membership crisis that led the union to seek shelter with its German parent organization Gewerkverein christlicher Bergarbeiter. In February 1914 the Christelijke Mijnwerkersbond became a branch of the German union, which promptly appointed a German president

65 Kreukels, Mijnarbeid, 190-193.

66 Christelijke Mijnwerker, 2, 9, 16, 23, 30 July 1910; 18, 25 March, 1, 8, 15 April, 2 September 1911: 'Het pensioenfonds der Staatsmijnen'; 10, 24 July 1910: 'Uit de betaalplaatsen'; 11 March 1911: 'Kristelijke mijnwerkers! Opgepast!'; 18 March 1911: 'De vergadering te Spekholzerheide'; 15 April 1911: 'Debatvergadering te Meerssen'; 22 April 1911: 'Organisatie'; 13 May 1911: 'Uit de betaalplaatsen'; 9 September 1911: 'Zou het waar zijn?'; 'Uit de betaalplaatsen'; 16 September 1911: 'Ingezonden'; 23 March 1912: 'Uit de betaalplaatsen'; 27 April 1912: 'Recht en Plicht'.

67 Ibid., 18 November 1911: 'De verkiezing voor de arbeiderscommissie op de Staatsmijn Wilhelmina'.

68 Christelijke Mijnwerker, 25 September 1915: 'Recht en Plicht'; 8 April 1916: 'Vergaderingen'. 
Figure 6.3 Membership development of CMB and ANMB, 1907-1930 (31 December)

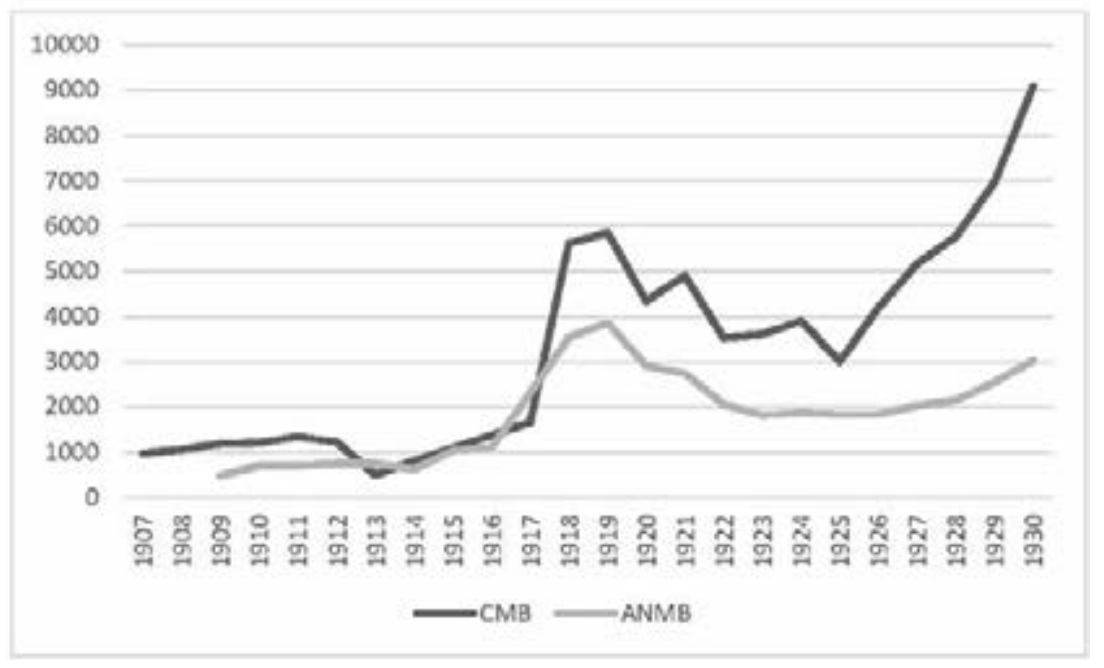

Source: Kreukels, Mijnarbeid, 578

from its own ranks with a decisive influence on strategies and actions. The German leadership instantly started a common action against the Kerkrade Domaniale Mijn jointly with the socialist union, involving both German and Dutch miners employed there. ${ }^{69}$

The main motive to merge was the general weakness of the Limburg union ('In the Wurmrevier the Chr. Gewerkschaft is much stronger and has reached greater results. Affiliation can bring that power to Limburg'), but this was argued for within the transnational paradigm in which the union had been formed and had been operating:

Our mining industry is in fact a continuation of the mining industry in the Wurmrevier. [...] Hundreds of workers from Kerkrade and other communities along the border are employed by German mines, and there are many branches of the German Christian miners' union on Dutch soil. These workers often change employers, and are also frequently employed in Limburg mines. This means they need to register with different organizations. [...] Also, for these workers, pension rights earned at German mines are lost. Therefore, an understanding between the pension funds of the

69 Dieteren, Mens en mijn, 99-103; Kreukels, Mijnarbeid, 178-179; De Mijnwerker, 2 April 1914: 'Officieel'; 9 April 1914: 'Vergadering van de Belegschaft der Domaniale Steenkolenmijn' (also in German); 16 April 1914: 'De samenwerking'; 'De actie te Kerkrade'. 
Limburg and the German mines is needed. This will be more easily attained if there is a connection between the Limburg and German miners' unions..$^{70}$

Additionally, referring to the Eschweiler Bergwerksverein's co-ownership of the mine Laura \& Vereeniging, cross-border cooperation was deemed necessary against German capital penetrating the Limburg mining district from the Aachen area. In its weekly De Mijnwerker, the ANMB was sceptical about this proclaimed 'internationalism' and reminded its readers of the (until then) national orientation of the смв..$^{71}$ Pragmatism in the transnational Limburg labour market appeared to have prevailed in its attitude. And it was highly selective: when many German miners had to leave after the outbreak of the war, the Christian union felt 'happy to be relieved of unwanted guests. Many elements among those foreigners, exceptions excluded, did not do honour to their fatherland and themselves', clearly referring to the German members of the socialist union. That many Germans were replaced by foreigners from anti-clerical Wallonia was not considered an improvement at all..$^{2}$ Nevertheless, inter-confessionalism German-style was defended because of the migrant labour force in the mines. ${ }^{73}$

\section{Membership shifts during the First World War and the 1917 miners' strike}

After the outbreak of the First World War in August 1914 everything changed. In the first year of the war many German miners left the Limburg mining district, partly because they were called up for military service. While before the war each month some 400 German nationals had applied to the Dutch mines for work underground, after September 1914 this number dropped to merely $40 .{ }^{74}$ Of the 1,876 German nationals employed in Dutch mines on 31 December 1913, only 1,098 were still there on that same date in 1914; for Austrian nationals (mainly Poles and Slovenes) these numbers were 429

70 Christelijke Mijnwerker, 21 February 1914: 'De aansluiting van den Christelijken Mijnwerkersbond bij den Duitschen Christelijken Mijnwerkersbond'.

71 De Mijnwerker, 7 March 1914: 'De aansluiting van den Christelijken Mijnwerkersbond bij den Duitschen Christelijken Mijnwerkersbond'; 22 May 1915: 'Verslag over het tijdvak 1 Januari 1913 tot en met 31 December 1914 (slot)'.

72 Christelijke Mijnwerker, 6 February 1915: 'Ongewenschte gasten'.

73 Ibid., 12 June 1915: 'De conclusie van den heer Haazevoet'.

74 Ibid.: 'Onze mijnindustrie'; 10 July 1915: 'Uit het jaarverslag der Staatsmijnen in Limburg'; 14 October 1916: 'Aantal mijnwerkers'. 
and $199 .{ }^{75}$ On the other hand, Dutch miners working in Germany up to that point turned or returned to the Limburg mines. In spite of the number of German and Austrian nationals employed in the Limburg mines steeply declining in 1914, figures for miners arriving from Germany and applying for a job in the Netherlands show a steady increase into that year. It is not possible to differentiate German from Dutch nationals in these data, but considering the decreasing numbers of Germans actually at work at the end of 1914 , this must be attributed to Dutchmen arriving from Germany. ${ }^{7}$ Several sources mention the employment of increasing numbers of skilled Dutch miners coming from abroad, replacing the Germans. ${ }^{77}$ During the war, Dutch mines employed an unknown number of German deserters as well. ${ }^{78}$

A high demand for labour in the Wurmrevier persisted, however. In the summer months of 1915 recruitment agents operating in the Dutch mining district were still attracting Dutch commuters. ${ }^{79}$ Commuting from the border communities continued during the war, but was severely hindered when the German authorities in 1917 forbade miners to bring their own food and drink across the border to prevent smuggling. ${ }^{80}$ In 1916 and 1917 the deteriorating food situation in Germany caused increasing misery for foreign miners; therefore the migration of Dutch nationals from Germany to the Limburg mining district continued. ${ }^{81}$

In 1917 it was reported that both Staatsmijnen and private mining companies had replaced as many of their German miners as possible by Dutchmen previously employed in (mainly) the Ruhr area. To house Dutch miners coming from Germany Staatsmijnen even built wooden barracks. ${ }^{82}$ Rising

De Mijnwerker, 3 February 1917: 'Ons zwarte goud'.

Langeweg, Mijnbouw en arbeidsmarkt, 92, graph 4.4.

77 Christelijke Mijnwerker, 19 December 1914: 'Arbeidsmarkt Limburgsche steenkolenmijnen'; 6 February 1915: 'Ongewenschte gasten'; 12 June 1915: 'Onze mijnindustrie'; 10 July 1915: 'Uit het jaarverslag der Staatsmijnen in Limburg'; 9 October 1915: 'De Limburgsche mijnindustrie in 1914'; 25 March 1916: 'Vrijheid of dwang'.

78 See for instance ibid., 1 December 1917: 'Economische toestand van het mijnbedrijf'. In 1919 the ANMB protested against the expulsion of German deserters: De Mijnwerker, 12 and 26 April 1919: 'Duitsche deserteurs' and 'Uitzetting'; 24 May 1919: 'n Beetje klein'.

79 Ibid., 15 August 1915: 'Een waarschuwing'; 21 and 28 August 1915: 'Gebrek aan geschoolde werkkrachten'; 4 September 1915: 'Zur Aufklärung'; 25 September 1915: 'Rapport overgelegd aan Zijne Excellentie den Minister van Landbouw, Nijverheid en Handel'.

8o Ibid., 15 September 1917: 'Donker vooruitzicht'; cf. Christelijke Mijnwerker, 8 September 1917: 'Arbeiders en arbeiders in Duitsland'; 13 and 27 October 1917, 13 April, 8, and 22 June 1918: 'Nederlandsche arbeiders in Duitschland'.

81 De Mijnwerker, 15 January 1916: 'Nederlandsche werklieden in Duitschland'; 19 February 1917: 'Een massa-ontslag'.

82 Ibid., 3 February 1917: 'Ons eigen zwarte goud'. 
demand for skilled miners was also met by Belgian miners from the nearby Liège district fleeing German occupation. In January 1914, 178 of 252 miners newly recruited from abroad who had been employed in a mine before had come from Germany, seventeen from Belgium. A year later this order was reversed: in January 1915, 53 came from Germany, 250 from Belgium. ${ }^{83}$ At the end of 1914 there were 1,098 Walloon miners in the Dutch mines. ${ }^{84} \mathrm{In}$ 1918 their number had grown to $3,155 \cdot{ }^{85}$

At first, Dutch miners coming or returning from Germany considered employment in a Dutch mine as temporary. This was an argument for not joining the (Christian) union: 'For me becoming a member makes no sense, because I will return to Germany anyway as soon as the war is over. ${ }^{86}$ Allegedly, working conditions in the Dutch mines were much worse than in the German ones: 'Generally [Dutch miners coming from Germany] tell us: if the war is over we will go back to Germany. Many of them do not like working in a Dutch mine and eagerly await the moment of returning to Germany. ${ }^{87}$ In 1916, the Christian union argued that its affiliation to the German union was still justified, as the border was only temporarily closed because of the war: 'In this time of war it can perhaps not be observed that easily, but in times of peace, when German and Dutch miners on mines in both countries work beside each other and continually migrate back and forth, close cooperation is ever more important. ${ }^{88}$

In the first years of the war, membership of the Christian union gradually started to rise again (Figure 6.3), perhaps because members of the former separatist union Recht en Plicht returned, but also because the union was starting to penetrate villages around Sittard and in the Meuse Valley (see Table 6.1). In 1915 and 1916 it gained a foothold in the new mining town of Hoensbroek near Heerlen, where State Mine 'Emma' had recently (1913) opened its gates, with a sudden membership rise from eleven to 106. Because of the growth of the mining population in the 'new' mining district, it was considered a breakthrough: 'What Kerkrade is for the older branches, Hoensbroek, Lutterade, and in the near future Brunssum are for the new ones. From Hoensbroek surrounding smaller communities can be canvassed more

83 Ibid., 3 April 1915: 'Onze loonactie'.

84 Ibid., 3 February 1917: 'Ons eigen zwarte goud'.

85 Langeweg, Mijnbouw en arbeidsmarkt, 131-135.

86 Christelijke Mijnwerker, 21 August 1915: 'Na den oorlog weer naar Duitschland'; 3 February 1917:

'Kan het verwondering wekken?'

87 De Mijnwerker, 24 March 1917: 'Terug naar Duitschland'.

88 Christelijke Mijnwerker, 14 October 1916: 'Onze zelfstandigheid bij loonacties'. 
Figure 6.4 By-laws of the Christelijke Mijnwerkersbond, 1914. Translation: 'Bylaws and internal regulations of the "Christelijke Mijnwerkersbond", Dutch branch of the "Gewerkverein Christlicher Bergarbeiter Deutschlands", located in Heerlen'

\section{STATUTEN}

EN

\section{HUISHOUDELIJK REGLEMENT}

VAN DEN

\section{„CHRISTELIJKEN MIJNWERKERSBOND”}

NEDERLANDSCH DISTRICT VAN DEN

„GEWERKVEREIN CHRISTLICHER

BERGARBEITER DEUTSCHLANDS"

GEVESTIGD TE HEERLEN.

ELETRISCHE DRUKKERU G. CORTEN, HEERLEN. 
easily.' ${ }^{89}$ The ANMB reported a membership rise in emerging Hoensbroek from 60 to 200 in 2015 as well, however. $9^{0}$

Because most of its German members were called up for military service, the ANMB particularly suffered after the war broke out. Many were reported to have been killed in military action. ${ }^{91}$ It at first mentioned $5^{0}$ per cent of its membership being called up for military service (in both the German and the Dutch armies); in retrospect it estimated the figure as 70 per cent. In 1917 at least 400 of its members were still in foreign (read: German) military service. ${ }^{92}$ Looking back in 1917 , the union recalled that at the outbreak of the war, our organization was almost completely torn apart; only a few hundred paying members were left. As almost all of its officers were withdrawn from the organization, it took a long time to regenerate. ${ }^{93}$ According to this report, at the end of 1914 membership had risen again to 615 , and two years later to 1,104 (see also Figure 6.3 and Table 6.1). In 1915 and 1916, more votes for ANMB candidates in elections of workers' representatives for State Mines 'Wilhelmina' and 'Emma', and for the Oranje Nassau Mijnen, signalled a growing sympathy among the miners. ${ }^{94}$

Under the slogan 'Hold International Solidarity High', the ANMB called upon 'workers of German, Austrian and Belgian nationality to join the Dutch miners' union', ${ }^{95}$ but there are no signs that this was really happening. The union argued against complaints that Belgians were privileged by the company directors over Dutchmen arriving from Germany..$^{96}$ Union officials of both the Dutch and Walloon miners' unions agitated together in Dutch and French among unorganized Belgian and Limburg miners in local meetings, ${ }^{97}$ and in 1915 and 1916 articles in French were published in De Mijnwerker to inform Walloon miners ${ }^{98}$ Because the Belgians were not

89 Ibid., 7 November 1915: 'Uit Hoensbroek'; 25 November: 'Vreemden, buitenlanders, of eigen volk'; 2 December 1916: 'Hoensbroek vooruit!'; 10 February 1917: 'Een overzicht over het jaar 1916'. 90 De Mijnwerker, 1 January 1916: 'Jaarverslag der afdeeling Hoensbroek'.

91 Ibid., 7 November 1914: 'De Ned. Mijnwerkersbond en den oorlog'; 28 November 1914: 'Gevallen op het veld der barbaren'; 1 May 1915: 'Nieuwe leden'; 22 May 1915: 'Ledenstatistiek'.

92 Ibid., 27 January 1917: 'Ned. Mijnwerkersbond'.

93 Ibid., 10 November 1917: 'Ons ledental'.

94 Ibid., 13 March 1915: 'Staatsmijn Wilhelmina'; 2 October 1915: 'n Mooie overwinning'; 5 February 1916: 'Een mooi succes'; 5 August 1916: 'Een overwinning'; 10 November 1917: 'Ons Kongres'.

95 Ibid., 27 February: 'Hoog de internationale solidariteit'.

96 Ibid., 13 March 1915: 'De vluchtelingenkwestie'.

97 Ibid., 4 September 1915: 'Van een vergadering'.

98 Ibid., 16 October 1915: 'Aux Belges'; 13 November 1915: 'Les resultats'; 12 February 1916: 'Notre action pour 1916'; 19 February 1916: 'Appèl aux Belges'; 26 February: 'Pourquoi?'; 25 March 1916: 'Les devoirs des mineurs'. 
allowed to organize in a trade union by the Dutch government, they were considered a 'brake' on the union's efforts to improve working conditions, ${ }^{99}$ but in the end this was disproved by their active involvement in the strike organized by the Dutch socialist union in June 1917.

In the first months of 1917, the rate of growth in ANMB membership started to increase. Figures indicating the rise in numbers in different sub-regions of the Limburg mining district (Table 6.2) show that this growth was exclusively concentrated in the Heerlen region and in Maastricht. Membership in the Kerkrade region even declined. The conclusion can hardly be avoided that the growth in Heerlen and surroundings was mainly due to Dutch miners coming from Germany and settling there. Most likely they had already experienced trade unionism and industrial action in the German coalfields. ${ }^{100}$

Table 6.2 Membership and net membership growth of the ANMB in the subdistricts of the Limburg mining district, 1 January-1 April 1917

\begin{tabular}{|c|c|c|c|c|c|c|c|}
\hline \multirow[b]{2}{*}{$\begin{array}{l}\text { ‘Old' mining district } \\
\text { (Kerkrade and surroundings) }\end{array}$} & \multicolumn{2}{|c|}{$\begin{array}{l}1 \text { January } \\
1917\end{array}$} & \multicolumn{2}{|c|}{$\begin{array}{l}1 \text { April } \\
1917\end{array}$} & \multirow{2}{*}{$\begin{array}{l}\begin{array}{l}\text { Net } \\
\text { growth }\end{array} \\
-8\end{array}$} & \multirow{2}{*}{$\begin{array}{l}\text { Growth } \\
\begin{array}{l}\% \\
-3 \%\end{array}\end{array}$} & \multirow{2}{*}{$\begin{array}{r}\begin{array}{l}\text { Share of } \\
\text { growth }\end{array} \\
-3 \%\end{array}$} \\
\hline & 277 & $(25 \%)$ & 269 & $(20 \%)$ & & & \\
\hline $\begin{array}{l}\text { 'New' mining district } \\
\text { (Heerlen and surroundings) }\end{array}$ & 493 & $(45 \%)$ & 665 & (49\%) & 172 & $35 \%$ & $69 \%$ \\
\hline Heerlen & 246 & & 325 & & 79 & & \\
\hline Other locations & 247 & & 340 & & 93 & & \\
\hline $\begin{array}{l}\text { Sittard and surroundings/ } \\
\text { Meuse Valley }\end{array}$ & 25 & $(2 \%)$ & 27 & $(2 \%)$ & 2 & $8 \%$ & $1 \%$ \\
\hline $\begin{array}{l}\text { Maastricht and surroundings } \\
\text { ('Heuvelland') }\end{array}$ & 269 & $(24 \%)$ & 342 & $(25 \%)$ & 73 & $27 \%$ & $29 \%$ \\
\hline Maastricht/Heer & 269 & & 324 & & 55 & & \\
\hline Villages (Meerssen) & - & & 18 & & 18 & & \\
\hline Roermond & 40 & $(4 \%)$ & 51 & $(4 \%)$ & 11 & $28 \%$ & $4 \%$ \\
\hline Total & 1,104 & & 1,354 & & 250 & $23 \%$ & $100 \%$ \\
\hline
\end{tabular}

Source: De Mijnwerker, 27 January 1917: 'Ned. Mijnwerkersbond', and 14 April 1917: 'Onze ledenstatistiek'

99 Ibid., 29 July 1916: 'Heerlensche correspondentie’; 12 August 1916: 'Eygelshoven'; 23 September 1916: 'Loondrukkers'; 21 October 1916: 'Geïnterneerden'; 13 January 1917: 'Belgische arbeiders'; 7 September 1918: 'Geïnterneerden'.

100 After the 1917 strike the Christelijke Mijnwerker observed that the strike had been well organized, because among the organizers there were 'men who had experienced such events earlier in Germany': Christelijke Mijnwerker, 5 July 1917: 'Glück auf, kameraden!' 
Maastricht is another story. It was no mining town; its main industry was pottery works, of which the ones owned by the Maastricht Regout family were the most important. During the First World War this industry was cut off from its markets and plunged into a crisis, with hundreds of pottery workers made redundant. Many of these workers turned to the booming Heerlen mining industry, commuting by train. In 1917 there were some 2,500 daily commuters from Maastricht. Since the late nineteenth century many Maastricht pottery workers had been left-leaning; the Social Democratic Party and its trade unions had a relatively large following there. As in the nearby Walloon industrial districts, employers' authoritarianism and workers' propensity to strike in the Maastricht potteries went hand in hand. Now Maastricht workers poured into the socialist miners' union. ${ }^{101}$ In April 1918 the Maastricht branch was reported to be the largest of the ANMB (with 300 members), because of a 'tremendous, sudden growth' in the foregoing period. ${ }^{102}$ In the 1920 s employment in the Maastricht industries started to grow again, and commuting by Maastricht miners gradually subsided. As consequence the Maastricht branch of the ANMB fell into a 'malaise'. ${ }^{103}$

In April 1917 the ANMB started a campaign for a wage rise, a minimum wage, and an eight-hour working day, after the смв had rejected a proposal to cooperate. ${ }^{104}$ Meetings in Heerlen on 17 May, in several different places in the mining district on 20 May, and again in Heerlen on 28 May attracted large numbers of miners supporting these demands. A Catholic newspaper wrote about the participation of 'Belgian miners, German deserters, and for the larger part: so-called Hollanders [Dutchmen from outside Limburg], ${ }^{105}$ and this surely reflects the social reality of the АNмB membership, but the later course of events made it clear that these were able to mobilize large parts of the miners outside their own ranks.

In early June a 'provisional committee' issued a call for a strike, and on 21 June it was officially called by the union. Until 24 June, 81 per cent of the miners joined the strike, but participation then declined quickly, as the ANMB's strike fund was not large enough to provide for the mostly unorganized strikers. Remarkably, despite outright opposition from the

101 Cf. Knotter, 'Het Boschstraatkwartier'; Perry, Roomsche kininie tegen roode koorts; Cillekens, 'Aardewerk en arbeidsmarkt'.

102 De Mijnwerker, 27 April 1918: 'Afdeeling Maastricht'; 20 December 1919: 'Het tienjarig bestaan van de afdeeling Maastricht'.

103 Ibid., 29 July 1922: 'Afdeeling Maastricht'.

104 On this campaign and the ensuing strike: Kreukels, Mijnarbeid, 220-247.

105 Cited ibid., 225. 
Christian union, its long-established Kerkrade branch, which had a tradition of dissidence, also participated in the strike. So, from a social perspective, a coalition of new members of the ANMB (both 'Hollanders' coming from Germany and former pottery workers from Maastricht) and Liège refugees working in the mines, all likely to have experience in industrial action, as well as Kerkrade dissidents in the Christian union with such experience as well, were able to lead the mass of unorganized Limburg miners (most of them with a rural background) into a mass movement, albeit a short-lived one. During the strike, the ANMB enlisted thousands of new members, many of whom left again, however, when the strike was over. After a rise to 3,00o during the strike in June, by August there were only 2,00o left. ${ }^{106}$ Nevertheless, by the end of 1917 the АNмB had outstripped the Christian union with 2,309 as against 1,656 members. Since January membership of the ANMB had more than doubled (Figure 6.3).

All this frightened the Catholic elites out of their wits. Their most prominent representative was the combative figure of Mgr. Henri Poels, a cleric who in 1910 had been appointed as the bishop's almoner for social affairs. ${ }^{107}$ Poels chaired the confessional Centrale Bond van Roomsch-Katholieke Mijnwerkersverenigingen (mentioned in the introduction as 'professional religious organization' of Catholic miners), but had no official function in the inter-confessional Christian union, which in accordance with its German parent organization did not allow clerical advisers on its board. Nevertheless, before, during, and after the strike, Poels acted as a mediator and representative on behalf of the Christian union, without any official mandate, consulting and deliberating with company directors and municipal authorities behind the scenes to prevent the socialists gaining influence. For him and others concerned with the social impact of miners' unionism, the strike was a wake-up call. First of all, in the wake of the strike he managed to convince the mining companies to install a permanent consulting body with the miners' unions (Contact-Commissie voor het Mijnbedrijf), which in 1920 would result in a first collective agreement, and in the longer term prepared the ground for a corporatist organization of the Dutch mining industry. ${ }^{108}$ As a mine director of the private Oranje Nassau Mijnen explained, the Contact-Commissie was installed as 'an instrument of peace; it is born 
from the wish of capital and labour in the mining industry to avoid conflicts as much as possible.. ${ }^{109}$

For Poels and his supporters, a second, and perhaps even more important, effect of the strike was that unity and determination in the Catholic camp were reinforced. Thanks to the strike, countervailing powers in Catholic Limburg could now be mobilized against the socialists, framed as a 'threat' from outside the province. ${ }^{110}$ From the start of his meddling in union affairs, Poels tried to invoke a specific Catholic Limburg regionalism against this perceived threat under the battle cry of 'Limburg for Christ'. ${ }^{111}$ Now this regionalism was reinforced. In 1918, a year of great social and political turmoil in nearby Germany and also in the Netherlands, ideological tensions rose to a maximum. In this confrontational atmosphere both the socialist and the Christian union both saw their membership rise to unprecedented heights (Figure 6.3).

Figures about the regional distribution of (net and gross) membership growth of both unions in their top year 1918 show remarkable and significant differences (Table 6.3). While the ANMB gained 94 per cent of its new members in mining and other towns, again with a clear concentration (64 per cent) in the Heerlen region, the смв gained only 40 per cent in towns. The remaining 60 per cent lived in villages in the countryside, 66 in total, where apparently it had managed to set up a whole series of new branches. Villages in the Sittard region (including the Meuse Valley) and the so-called Heuvelland south-east of Maastricht stand out. Only a few years before, the union had not been able to reach miners living there. This clearly demonstrates that the Christian union had finally made a breakthrough among the Limburg miners of rural origin, most certainly with more than a little help from the local clergy. We may suspect that the combined appeal of unionism and anti-socialist Catholic regionalism had drawn them into the organization. During the inter-war years the Christian union (Catholic after 1926) continued to recruit its members disproportionately in smaller communities: in 194064.5 per cent of its membership lived there, against only 40.3 per cent of the mining population as a whole. ${ }^{112}$

109 Cited by Kreukels, Mijnarbeid, 255.

110 Ibid., 244-245; Christelijke Mijnwerker, 20 February 1916: 'Wassende roode vloed'.

111 For instance, ibid., 13 August 1910: 'RK Mijnwerker-Propagandadag'; 12 and 19 August 1911: 'Mijnwerkerspropagandadag te Kerkrade'; 26 August 1911: 'Limburg aan Christus'; 9 December 1911: 'Huisbezoek'; 17 June 1916: 'De 17de Limburgsche Katholiekendagen'.

112 Kreukels, Mijnarbeid, 335 . 
Table 6.3 Membership growth of the смв (net) and the ANмB (gross) in the towns and villages in sub-districts of the Limburg mining district, 1918

\begin{tabular}{lrrrr}
\hline & CMB & \% & ANMB & $\%$ \\
\hline Old mining district around Kerkrade & & & & \\
Kerkrade municipality & & & & \\
Villages around Kerkrade (3) & 262 & 5 & 60 & 2 \\
New mining district around Heerlen & 11,018 & 20 & 2,384 & 64 \\
Mining towns** & 718 & 14 & 71 & 2 \\
Villages around Heerlen (12) & & & & \\
Sittard and surroundings/Meuse Valley & 255 & 5 & 374 & 10 \\
Sittard & 1,040 & 21 & 5 & 0 \\
Villages around Sittard and in the Meuse valley (23) & & & & \\
Maastricht/Heuvelland & 120 & 2 & 365 & 10 \\
Maastricht & 834 & 16 & 60 & 2 \\
Villages around and south-east of Maastricht (23) & & & & \\
Roermond and surroundings & 91 & 2 & 204 & 6 \\
Roermond & 168 & 3 & 0 & 0 \\
Villages around Roermond (5) & $\mathbf{5 , 0 6 1}$ & $\mathbf{1 0 0}$ & $\mathbf{3 , 6 9 8}$ & $\mathbf{1 0 0}$ \\
\hline Total & & & & \\
\hline
\end{tabular}

* Kerkrade, Bleyerheide, Kaalheide, Spekholzerheide, Chèvremont, Haanrade.

**Heerlen/Heerlerheide/Heerlerbaan/Bautsch, Brunssum/Treebeek, Schaesberg, Hoensbroek. Sources: смв: Algemeene Bond van Christelijke Mijnwerkers in Nederland, Kort verslag over 1918 (Heerlen 1919) 2-3; ANmB: De Mijnwerker, 9 February, 16 March, 6 April, 4 May, 1 June, 6 July, 3 August, 7 September, 7 November 1918, 4 January 1919: 'Nieuwe leden'

\section{Border issues after the war: currencies and commuters}

Looking back on the miners' strike some months later in the autumn of 1917, the Christian union explained its refusal to join by its concern for the 'national interest': as during the war the Netherlands had become dependent on coal supply from the Limburg coalfield, a strike would have had disastrous consequences for the Dutch economy. So, by opposing the strike, the Christian union had upheld the 'national idea'. This argument was connected to a broader discussion about the relationship between a transnational and a national orientation of the union. At the one hand, it was admitted that 'the Limburg miners feel more related to the workers and miners' organizations in nearby Germany than to faraway organizations elsewhere [in the country]. Hence, we cannot denounce former members and officials having sought close cooperation with the German Christian miners' union. Here, at the borders, the interests of the workers were 
mutually dependent to such an extent that [...] continuous exchange between the Dutch and German unions had to be a consequence.' On the other hand, however, 'most certainly large national interests tie our miners' union to the other national Christian trade unions', for instance because of 'social security, that for our mining district has to be arranged by the Dutch government'. ${ }^{113}$ It was a sign of a reorientation from the transnational to the national. In 1922 this argument would become decisive in breaking with the German union and continuing independently as a national organization: it was a prerequisite to participate in the state unemployment fund, conceived as a national system to subsidize the union's unemployment benefits. ${ }^{114}$

In the period leading up to this break, divergent economic developments in Germany and the Netherlands caused a much sharper demarcation of the border and a split of the Dutch-German labour market, which would profoundly influence the Christian union's attitude. While before the war free and abundant circulation of German currency in the Dutch mining district lubricated the cross-border labour market, now diverging monetary developments caused a sharp division. As a consequence of the First World War and the reparations forced on Germany by the Treaty of Versailles, the German monetary situation deteriorated quickly; it was the period of hyperinflation, when the German mark was losing value on a daily basis. Salaries in the Netherlands were paid in stable Dutch guilders, which presented a huge advantage for German commuters who could spend their wages in Germany. In the early 1920s the purchasing power of wages earned in the Dutch mines was estimated to be three times as high as those in the German mines; as a consequence, it became extremely attractive for German miners to commute to the Netherlands.

The result was a massive influx of experienced German workers leaving their former German employers to cash in in the Netherlands. Contemporaries referred to them as Guldenmänner ('men of the guilders'). Dutch miners who had until then been working in German mines returned, ${ }^{115}$

113 Christelijke Mijnwerker, 13 October 1917: 'De mijnwerker en de nationale vakbeweging'. 114 In 1921 the CMB was still convinced that it was in the workers' interest to connect not only nationally, but also internationally with like-minded organizations: ibid., 15 May 1921: 'Overzicht over den stand, de ontwikkeling en de verrichtingen van de Christelijken Mijnwerkersbond in het jaar 1920'.

115 De Mijnwerker, 26 April 1919: 'n Veeg teken'; 3 May 1919: 'Verslag jaarvergadering 27 April 1919'; 18 October 1919: 'Staking Zeche Nordstern'; 8 November 1919: 'Nabetrachting'; 6 December 1919: 'Rekening en verantwoording van het Stakings-comité der Mijn Nordstern'; 20 December 1919: 'Vaals'; 24 January 1920: 'Nordstern'; Christelijke Mijnwerker, 25 October 1919: 'De staking der 
and German miners from the mining communities at the border flooded into the Netherlands, both as migrants and commuters. Their number rose sharply from 1,670 in 1919 to 5,342 in 1923. In 1922, 11 per cent of the workers underground were German commuters. With the stabilization of the Reichsmark in November 1923 hyperinflation came to a halt, and this immediately affected the flow of commuters from Germany: most of them returned to their former employers. After 1923 their number declined to a steady 1,000-1,200 between 1925 and 1931. ${ }^{116}$

As a consequence of German migrants arriving in the Netherlands, German membership of the ANMB started to rise again. ${ }^{117}$ In 1920 the union held meetings and called upon 'German comrades' to join the ANMB to prevent competition over wages. ${ }^{118}$ German-speaking propagandists were appointed specifically to address German miners, as there were 'several parts in the district where only German is spoken'. ${ }^{119}$ German members appear to have actually formed new branches in Bocholtz and Simpelveld, ${ }^{120}$ and were also mentioned in the Heerlerheide and Schaesberg branches. ${ }^{121}$ During a strike at the Dominiale Mijn in 1921, conducted in coordination with the Christian union, the ANMB held separate meetings with German strikers on both sides of the border. ${ }^{122}$

In 1921, the ANMB tried to unionize German cross-border commuters as well, arguing that, even if already in the Alte Verband, they should be organized in the country where they held their jobs. Branches were set up in localities across the German border: in Kohlscheid (eighteen members), Kohlberg-Straß (sixteen), Ubach (eighteen), and Scherpenseel (24). ${ }^{123}$ However, in 1922 the union had to admit that it had hardly any members among the Germans who crossed the border on a daily basis. ${ }^{124}$ It called

Hollandsche mijnwerkers op de mijn Nordstern (Wurmrevier)'; 17 and 24 July 1920: 'Op de Duitsche mijnen'; 22 January 1921: 'Voor de arbeiders, welke werkzaam zijn op de Duitsche mijnen'; 1 February 1921: 'In de waanzinnige wereld'; 26 March 1921: 'Antwoord aan het kamerlid De Jonge'. 116 Langeweg, Mijnbouw en arbeidsmarkt, 140-148, apps. 12, 15.

117 De Mijnwerker, 2 August 1919: 'Voor de grensafdeelingen'; 4 October 1919: 'Kohlennot und Behandlung der Bergarbeiter'.

118 Ibid., 3 April 1920: 'Uit de Afdeelingen'; 2 October 1920: 'Deutsche Kameraden in Limburg'; 4 December 1920: 'Duitsche mijnwerkers'.

119 Ibid., 5 June 1920: 'Verslag Congres ANMB'.

120 Ibid., 14 August 1920: 'Welkom'.

121 Ibid., 3 April 1920 and 20 January 1921: 'Uit de Afdeelingen'.

122 Ibid., 30 July 1921: 'District V'; 6 August 1921: 'Na den eersten dag van strijd!'; 20 August 1921: 'Solidariteit'. On this strike: Kreukels, Mijnarbeid, 340-358.

123 De Mijnwerker, 15 October 1921: 'District V: Twee nieuwe afdeelingen'; 22 October 1921: 'District V: Alweer 2 Afdeelingen'.

124 Ibid., 18 November 1922: 'Vreemde werkkrachten'. 
for a 'tighter connection of our organized members with their German companions ${ }^{125}$ and spoke out against the Christian union, which was protesting against the 'invasion' of German workers. ${ }^{126}$ The Christian union in its turn accused the ANMB of 'action against the closure of the border.' ${ }^{127}$ The socialist union defended the 'freedom of German workers to look for work in the Netherlands', as much as it demanded the same freedom for Dutch workers in Germany. ${ }^{128}$

The attitude of the Christian union towards German migrants and commuters was much more ambivalent and even outright hostile. While it professed that 'it had no objection to the employment of decent German workers, members of the Gewerkverein applying for help and support at the union's office', it warned against the uncontrolled migration of 'radical-communist elements' and against German commuters working below wage standards. Earning easy money in this way, they were accused of disregarding employment rights and collectively agreed wage rates. ${ }^{129}$ Dutch workers would suffer from the employment of increasing numbers of German miners, especially of experienced German overseers who prevented promotion of Limburg assistant-overseers and hewers. ${ }^{130}$ To prevent unemployment of Dutch miners, the смв pleaded for the 'gradual dismissal of recently arrived Germans' to be replaced by Dutchmen, and demanded measures by the government against the employment of miners from outside the Netherlands. ${ }^{131}$ In October 1922 the Christian union started a campaign against 'foreign workers in Limburg', with a protest meeting on 5 November. Interpellations were held in the Dutch Parliament, and the Catholic minister of social affairs came to Heerlen to discuss the matter with employers and unions. In the end the minister sided with mine management in considering that employment of Dutch

125 Ibid., 15 April 1922: 'Ons congres'.

126 Ibid., 14 October 1922: 'Aan de Staatsmijnen. Bevoorrechting van Duitsche arbeiders'; 4 November: 'Een protestvergadering', 'Een abuis van Janus'; 18 November 1922: 'Een vergissing'. 127 Ibid., 25 November 1922: 'Vreemde werkkrachten'; 2 December 1922: 'Pers en polemiek'; Christelijke Mijnwerker, 31 December 1922: 'Over vreemde werkkrachten in Limburg'. 128 De Mijnwerker, 9 June 1923: 'Langs den weg'; 10 November 1923: 'Propaganda onder de Duitschers'.

129 Christelijke Mijnwerker, 15 October 1922: 'De ontevredenheid onder de Mijnwerkers III'. 130 Ibid., 16 October 1920: 'Duitsche mijnwerkers'; 31 October 1921: 'Duitsche opzichters bij ons Mijnbedrijf'; 6 November 1921: 'Houwers d.d. Hulpopzichters'; 19 November 1922: 'Limburgers in Limburg'.

131 Ibid., 27 March 1921: 'Werkloosheid in de Mijnindustrie'; 11 December 1921: 'Verzonden telegrammen'; 18 December 1918: 'De crisis in de Mijnindustrie en de buitenlandsche arbeiders'; 15 and 22 January 1922: 'Buitenlandsche arbeiders in de Mijnstreek'; 14 May 1922: 'Werkloosheid'. 
workers was not at risk, and no measures were taken to control crossborder labour. ${ }^{132}$

It is highly significant that this campaign against the 'invasion' of German workers came after the смв had seceded from the Christliche Gewerkverein on 1 October 1922. That it required a break with the Gewerkverein becomes clear from a statement by the Aachen Bezirksleiter Peter Harsch in December 1922:

If the Christian Miners' Union opposes the employment of German workers in the interest of Dutch workers, then the Gewerkverein has nothing to do with this. Since 1 October, the Christian Miners Union has been completely independent. This union defends the interests of the Dutch workers, while the Gewerkverein has to defend those of the German workers. In the interest of the German miners the Gewerkverein has to take a stand against the demand that the borders should be closed for these workers. ${ }^{133}$

For the Christian union independence from the German union was necessary to participate in the state unemployment benefit scheme which had been in place since $1917{ }^{134}$ According to this so-called Werkloosheidsbesluit 1917 unemployment benefits by Dutch trade unions could be supported by government subsidies. Unlike the ANMB, which had joined this state fund already in August 1921, the Christian union had initially decided not to do so. ${ }^{135}$ The union's change of heart in 1922 was connected to cross-border migration: the unfavourable exchange rate prevented Dutch miners avoiding unemployment by seeking work in German mines. The union reasoned that, if exchange rates returned to normal, Limburg workers would no longer be bound to the Limburg labour market and would be able to find work in Germany again at reasonable wages. But, as there was no prospect that such a situation would return, the union had to change its attitude towards unemployment insurance and align with government regulations on this issue. ${ }^{136}$

132 Langeweg, Mijnbouw en arbeidsmarkt, 137-138; Christelijke Mijnwerker, 5 November 1922: 'Protestvergadering. De vreemde arbeiders in Limburg'; 26 November and 3 December 1922: 'Vreemde arbeiders'; 10 December 1922: 'De conferentie met Minister Aalberse'.

133 Ibid., 31 December 1922: 'Een aanval op Harsch'.

134 Dieteren, Mens en mijn, 122; Christelijke Mijnwerker, 10 September 1922: 'Verslag van de Conferentie van Afgevaardigden'.

135 De Mijnwerker, 15 August 1921: 'Officieele mededelingen'; 11 September and 9 October 1919: 'Werkloozenverzekering'; 17 March and 11 June 1920: 'De werkloozenverzekering'.

136 Christelijke Mijnwerker, 28 May 1922: 'Werkloosheidsverzekering'; 15 October 1922: 'De ontevredenheid onder de Mijnwerkers'. 


\section{Continuous support for the socialist union and the CMB's turn to Catholic regionalism}

There was another, more hidden motive for the national turn of the CMB and the break from the Gewerkverein, however: in the election for workers' representatives in the committees administering the general miners' pension and sickness fund (Algemeen Mijnwerkers Fonds) in May 1922, the socialist union unexpectedly pulled off a resounding victory. It won 29 of the 50 available seats. ${ }^{137}$ The Algemeen Mijnwerkers Fonds (AMF) was established in 1919 as a general insurance fund for the mining district as a whole. It was managed by representatives of employers and workers, assisted by committees at each mine consisting of two representatives of management and five elected by the workers. ${ }^{138}$ Insurance premiums were paid by both employers and workers, but from the beginning the ANMB had campaigned for a premium-free fund which was fully paid for by the employers. ${ }^{139}$ In 1920 a petition was held in support of this goal, which was fiercely opposed by the Christian union..$^{140}$ In the elections for the workers' representatives in 1922 the ANMB put a premium-free fund again at the centre of its demands, ${ }^{141}$ and both unions were convinced that this had caused the socialist victory. ${ }^{142}$

According to the Christian union, German votes had significantly contributed to the socialist majority, both because of the Germans' socialist convictions and for opportunistic reasons: ' 80 per cent of the foreigners, if not all, are socialists, or have a socialist orientation. [...] The majority working here are organized in the red union.' The German miners were, moreover, accused of opportunism: as they considered their presence in the Dutch mines as temporary, they had no interest in the sustainability

137 Kreukels, Mijnarbeid, 334-337 and 582; Dieteren, Mens en mijn, 125-127.

138 Ibid., 181-188.

139 In 1911 a similar campaign had been organized by the ANMB with regard to the pension fund of Staatsmijnen. See note 66.

140 De Mijnwerker, 17 April 1920: 'Op voor premievrij pensioen'; 5 June, 10 and 17 July 1920: 'Het premievrij pensioen'; 18 December 1920: 'Petitionnement voor premievrij pensioen'; Christelijke Mijnwerker, 29 May 1920: 'Hij wilde niet teekenen'; 5 and 12 June 1920: 'Onzinnig geklets'; 'Rondom het Algemeen Mijnwerkersfonds'; 26 December 1920: 'Een mager resultaat'.

141 De Mijnwerker, 22 April 1922: 'Ons Paaschcongres'; 6 May 1922: 'Premievrij pensioen centrale eis in verkiezing fondscommissies'.

142 Christelijke Mijnwerker, 28 May 1922: 'Uitslag verkiezingen Fondscommissieleden'; 'Een Zegepraal van de Domheid'; 'Na den Strijd'. 
of the fund, and hence voted for a premium-free one. ${ }^{143}$ The socialist union agreed that the German vote had been important, but of course not that this was for opportunistic reasons. ${ }^{144}$ That socialist support had been growing among Limburg miners as well can be shown by victories in elections for workers' committees at several mines in 1921 and 1922, in which Germans were not allowed to vote. ${ }^{145}$ The смв had to admit that German support had not been decisive for the socialist victory, as, for instance, the ANMB also gained a majority in the CMB's stronghold Kerkrade and surroundings as well, and allegedly 9o per cent of the so-called train men from rural villages had voted for a red candidate. The 'train men' were supposed to have opted for a premium-free pension because they did not consider mine work a permanent job. ${ }^{146}$ The main cause, however, was a lack of ideological conviction: "The mass of unorganized workers, largely Catholics, continuously change their allegiances from one side to the other, because it is not clearly demonstrated to them what the difference is between the socialist and the Christian organization. ${ }^{.47}$

Three years later, any decisive impact of the German votes was proven wrong at the 1925 election for workers' representatives in the AMF administrative committees. At that time most of the German migrants and commuters had left the Limburg mining district, but the socialist union gained an even larger victory of 31 seats. Again these gains were preceded by electoral successes in workers' committees at several mines. For the ANMB, these were a sign that indigenous Limburg miners had turned to their side ${ }^{148}$ and that 'some of the Limburg miners, who last time voted for the Christian list, now sympathize with us'. ${ }^{149}$ After the elections it concluded: 'The German companions have not been decisive this time either. No, this time our Limburg brethren helped to fight for victory. ${ }^{\prime 10}$ The regional press blamed the successive wage cuts in the mining industry, which had been fiercely

143 Ibid., 'Een nabetrachting', 'De wijze van stemmen'; 4 June 1922: 'Socialistische zegepraal'; 'Nog een nabetrachting'.

144 De Mijnwerker, 17 June 1922: 'Gouden tijden tegemoet'.

145 Ibid., 4June 1922: 'Verkiezingen op de Domaniale Mijn; 30 July 1921: 'Een schitterende overwinning' (Laura); 6 August 1921: 'Uit de Afdeelingen' (Eygelshoven); 28 January and 11 March 1922: 'De uitslag van de verkiezingen'; 'Naar aanleiding eener verkiezing' (Emma); 29 April 1922: 'Verslag Congres'.

146 Christelijke Mijnwerker, 28 May 1922: 'Een Zegepraal van de Domheid'; 'Een nabetrachting’. 147 Ibid., 11 June 1922: 'Roode successen in de Mijnstreek'.

148 De Mijnwerker, 6 September 1924: 'De schitterende overwinning op Staatsmijn Hendrik'; 28 March 1925: 'Een schitterende overwinning'; 4 April 1925: 'De overwinning op de Laura'.

149 Ibid., 9 May 1925: 'Oproep aan de leden'.

150 Ibid., 30 May 1925: 'Na den strijd'; 13 June 1925: 'Nogmaals de verkiezingsuitslag'. 
opposed by the socialist union, but accepted by the Christian one. ${ }^{151}$ In spite of a joint call by the Limburg priests in the miners' villages to vote for the Christian union, ${ }^{152}$ 'the large majority of Catholic miners believed the socialist arguments [against wage cuts]. Out of revenge against the Christian miners' union and as a protest against its acceptance of the wage deal, they chose men in the committees who were completely alien to them.'153 The смв had to conclude that 'our union cannot put confidence in the large non-unionized mass running loose'. ${ }^{154}$

As a reaction to this loss of confidence, the смв deemed it necessary to strengthen the ideological convictions of the Catholic miners. ${ }^{155} \mathrm{On}$ 13 June 1926 the union was officially renamed the Nederlandsche RoomschKatholieke Mijnwerkers Bond (Dutch Roman Catholic Miners' Union). Its target was 'the soul of the Catholic worker': 'if in today's circumstances we were able to champion our Catholic principles more openly, both inwards and outwards [...], then we would bring the miners into a Catholic milieu, which would be undeniably attractive to the souls of the workers'. ${ }^{156}$ Mgr. Poels was now officially appointed as the union's clerical adviser, and local priests or chaplains were appointed as advisers in each separate branch. ${ }^{157}$ In cooperation with the workers' professional religious organization (standsorganisatie) a propaganda offensive was launched against free-thinking, socialism, neo-Malthusianism, and all other influences perceived as threats to the Limburg Catholic way of life. In each parish propaganda clubs were formed to distribute leaflets and brochures and to organize visits and meetings. The aim was to encourage lukewarm or apostate workers to participate in Catholic unions. To strengthen the 'inner religious convictions', in 1929 mutual membership of the Catholic miners' union and the professional religious organization became obligatory. ${ }^{158}$ All this was underpinned by a regionalist discourse. And it worked: between 1926 and 1931 membership of the Catholic union doubled, while the ANMB increased by less than 50 per cent (Figure 6.3). ${ }^{159}$ In the 1930s, when a new

151 Christelijke Mijnwerker, 7 June 1925: 'Enkele persstemmen'.

152 Ibid., 17 May 1925: 'Een zeer belangrijk schrijven'.

153 Ibid., 1 November 1925: 'Een Nabetrachting'.

154 Ibid., 31 May 1925: 'De afloop van den strijd'.

155 Ibid., 2 and 16 August 1925: 'De positie van den Chr. Mijnwerkersbond in de Mijnstreek' and 'De inleiding van onzen Bondsvoorzitter'; 1 November 1925: 'Een Nabetrachting'.

156 Ibid., 11 July 1926: 'Een nabeschouwing'.

157 Dieteren, Mens en mijn, 122-123.

158 Ibid., 261-262; Jacobs, Het gouden boek der KAB, 169-170.

159 Kreukels, Mijnarbeid, 162-164, 263, 320. 
generation of native Limburg miners was recruited into the industry, this tendency was reinforced. ${ }^{160}$

\section{Conclusion}

As Patrick Pasture argues, the anti-socialism of Christian trade union movements in Europe generally went hand in hand with nationalist and, often, outspoken regionalist attitudes. ${ }^{161}$ In the Limburg mining district this was not initially obvious. In the period leading up to the First World War, cross-border mobility of Dutch and German miners logically led both miners' unions, including the Christian union, to adopt a transnational approach. The German examples of the socialist Alte Verband and the inter-confessional Gewerkverein christlicher Bergarbeiter had a decisive influence on the organization of Dutch miners' unionism. For the Christian union this might have been more for pragmatic than for principled reasons, but the transnational labour market left a mark on its cooperation with the Gewerkverein, up to its incorporation in 1914.

This changed during and after the First World War. National economies grew apart, borders became barriers, and labour markets became nationalized. The effects of the closing of the border could be observed already during the war. German miners had to leave the Limburg district, and miners of Dutch origin moved in. They strengthened the position of the socialist union. After the war, cross-border commuting returned but, while before the war this had been a two-way phenomenon of labour market integration, now it was a one-way consequence of economic discrepancies, i.e. diverging monetary developments in Germany and the Netherlands. The Christian union started to change its attitude: while it had originally considered cross-border commuting by both German and Dutch miners to be normal, it now developed a degree of mistrust towards German commuters. They were believed to be competing with Limburg miners, both over wages and over promotion, and, worst of all, too many of them brought socialist ideas into the miners' movement.

As a consequence, the Christian union lost its cross-border orientation. Ties with the German Gewerkverein were broken in 1922, formally to be able to participate in the national unemployment fund, but it can 
also be explained by the Dutch Christian union's growing opposition to the influx of German miners. It was a first step towards nationalization and regionalization. In 1926 the Christian union formally abandoned inter-confessionalism and became Catholic also in name. In 1925 it had already affiliated to the recently established Catholic national trade union federation Roomsch Katholiek Werklieden Verbond. The break with the German inter-confessional union not only resulted in a reorientation to the national Catholic federation, however, but also to a much greater emphasis of the Catholic confessional character of the union. The aim was to better connect with regional Catholicism and to draw Limburg Catholic miners together in the struggle against the alarmingly strong influence of the socialist union. In this struggle Catholicism and Limburg regionalism were intimately connected. Catholic regionalism had been part and parcel of the influential clerical discourse of Mgr. Poels, who was now officially admitted as a clerical adviser. It was a far cry from the inter-confessional union's original transnationalism.

In significant contrast, the socialist union did not change its attitude towards migrants and commuters from Germany in the 1920s. From its transnational origins it tried to organize miners regardless of nationality, and before the First World War it had a mixed Dutch-German membership. During the war new recruitment resulted in a membership shift: German membership declined as a consequence of war mobilization and border closure. Maastricht as well as miners' colonies in the new mining district around Heerlen became strongholds. After the war the socialist union continued its inclusive strategy. It refused to oppose commuting from Germany, instead trying to win over German commuters as members. It is not clear, however, to what extent this really happened. Partly because of German support it was able to win elections of workers' representatives in the commissions of the pension fund AMF in 1922. In 1925 it became clear that its strategies were supported widely among Limburg miners as well. Nevertheless, in the long run, the АNMB continued to be perceived as an outsider and was not able to connect with the mass of Limburg miners. 


\section{Appendix 6.1 Map of dwelling places of miners mentioned in Chapter 6}

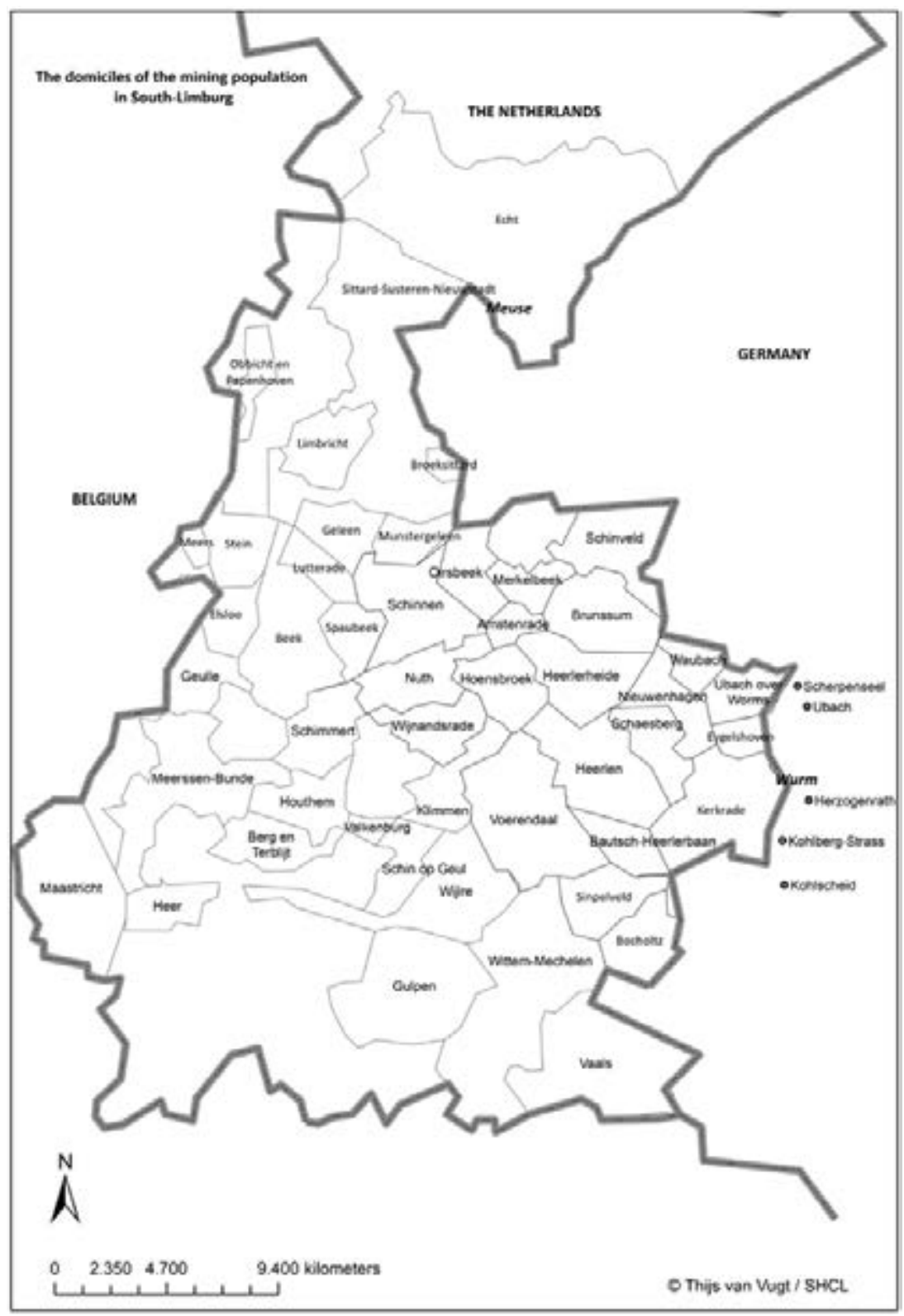


Appendix 6.2 Membership of CMB (1915) and ANMB (1916), gross monthly growth of ANMB (1913), miners living in the Limburg mining district (1909), and workmen's train fares issued in 1911

\begin{tabular}{|c|c|c|c|c|c|}
\hline Communities & $\begin{array}{l}\text { смв } \\
31 \text { Dec. } \\
1915\end{array}$ & $\begin{array}{l}\text { Gross } \\
\text { monthly } \\
\text { growth } \\
\text { ANMB } \\
1913\end{array}$ & $\begin{array}{l}\text { ANMB } \\
31 \text { Nov. } \\
1916\end{array}$ & $\begin{array}{l}\text { Miners } \\
1909\end{array}$ & $\begin{array}{l}\text { Work- } \\
\text { men's } \\
\text { fares } \\
1911\end{array}$ \\
\hline \multicolumn{6}{|c|}{ ‘Old' mining district (Kerkrade and surroundings) } \\
\hline Kerkrade & 175 & 39 & 74 & 2.677 & 30 \\
\hline Bleijerheide $^{*}$ & 61 & & & & \\
\hline Kaalheide ${ }^{*}$ & 32 & 37 & 63 & & \\
\hline Bocholtz & 31 & 27 & & 110 & \\
\hline Spekholzerheide* & 164 & 39 & 36 & & \\
\hline Chèvremont $^{*}$ & 144 & 15 & 44 & & \\
\hline Haanrade ${ }^{*}$ & 16 & & & & \\
\hline Eygelshoven & 14 & 33 & 60 & 165 & 50 \\
\hline Simpelveld & & & & 97 & 300 \\
\hline \multicolumn{6}{|c|}{ ‘New' mining district (Heerlen and surroundings) } \\
\hline Heerlen & 63 & 183 & 132 & 1.343 & 200 \\
\hline Heerlerheide ${ }^{* *}$ & & & 82 & & \\
\hline Bautsch $^{* *}$ & & 29 & 32 & & \\
\hline Nuth & 4 & & 19 & 72 & 130 \\
\hline Schinnen & 22 & & & 113 & 120 \\
\hline Schaesberg & 72 & 18 & 64 & 401 & 100 \\
\hline Hoensbroek & 25 & 47 & 98 & 137 & 75 \\
\hline Waubach & 17 & 4 & & & \\
\hline Brunssum & & 14 & 52 & 33 & \\
\hline Nieuwenhagen & 70 & 39 & & 285 & \\
\hline Voerendaal & & 1 & 14 & 97 & \\
\hline Ubach over Worms & & & & 202 & \\
\hline Amstenrade & & & & 27 & \\
\hline Merkelbeek & & & & 19 & \\
\hline Oirsbeek & & & & 22 & \\
\hline Schinveld & & & & 8 & \\
\hline Wijnandsrade & & & & 15 & \\
\hline \multicolumn{6}{|c|}{ Sittard and surroundings/Meuse Valley } \\
\hline Sittard & 20 & 18 & 11 & 195 & $445^{* * *}$ \\
\hline Broeksittard & 15 & & & 18 & \\
\hline Stein & 45 & & 14 & 20 & \\
\hline Echt & 31 & & & & 14 \\
\hline Meers & 20 & & & & \\
\hline
\end{tabular}




\begin{tabular}{|c|c|c|c|c|c|}
\hline Communities & $\begin{array}{l}\text { смв } \\
31 \text { Dec. } \\
1915\end{array}$ & $\begin{array}{l}\text { Gross } \\
\text { monthly } \\
\text { growth } \\
\text { ANMB } \\
1913\end{array}$ & $\begin{array}{l}\text { ANMB } \\
31 \text { Nov. } \\
1916\end{array}$ & $\begin{array}{l}\text { Miners } \\
1909\end{array}$ & $\begin{array}{l}\text { Work- } \\
\text { men's } \\
\text { fares } \\
1911\end{array}$ \\
\hline Elsloo & 11 & & & 62 & \\
\hline Beek & 7 & & & 49 & 170 \\
\hline Lutterade & 13 & & & & \\
\hline Obbicht & 17 & & & & \\
\hline Spaubeek & & & & 42 & 200 \\
\hline Geleen & & & & 107 & 370 \\
\hline Munstergeleen & & & & 31 & \\
\hline Limbricht & & & & 7 & \\
\hline \multicolumn{6}{|c|}{ Maastricht and surroundings ('Heuvelland') } \\
\hline Maastricht & 22 & 72 & 242 & & 350 \\
\hline Wijlre & 16 & & & 15 & 180 \\
\hline Mechelen & 9 & & & & \\
\hline Berg \& Terblijt & & & & 14 & \\
\hline Geulle & & & & 19 & \\
\hline Gulpen & & & & 20 & \\
\hline Houthem & & & & 20 & \\
\hline Heer & & & 27 & 8 & \\
\hline Klimmen & & & & 44 & \\
\hline Meerssen & & 19 & & 37 & $335^{\dagger}$ \\
\hline Schin op Geul & & & & 12 & \\
\hline Schimmert & & & & 7 & \\
\hline Vaals & & & & 37 & \\
\hline Valkenburg & & & & 17 & 170 \\
\hline Roermond & & & 40 & & 130 \\
\hline
\end{tabular}

*Part of Kerkrade municipality.

${ }^{* *}$ Part of Heerlen municipality.

${ }^{* * *}$ Incl. Susteren, Nieuwstadt.

${ }^{\dagger}$ Incl. Bunde.

Sources: смB 1915: Christelijke Mijnwerker, 25 March 1916: 'Onze districtsvergadering'. ANMB 1913:

De Mijnwerker, 25 January, 19 April, 17 May, 21 June, 25 October, 22 November, 13 December 1913; 14 February 1914: 'Ledenstatistiek'. ANMB 1916: De Mijnwerker, 27 January 1917: 'Ned.

Mijnwerkersbond'. Miners 1909: Centraal Bureau voor de Statistiek, Uitkomsten der Beroepstelling in het Koninkrijk der Nederlanden gehouden op den een en dertigsten december 1909. Eerste deel. Overzicht voor iedere gemeente van Nederland van de voornaamste beroepen, die in de gemeente worden uitgeoefend [...] [Bijdragen tot de Statistiek van Nederland, Nieuwe Volgreeks No. CLXVII] (The Hague 1912). Workmen's fares 1911: Christelijke Mijnwerker, 16 December 1916: 'Weekkaarten voor arbeiders' 


\title{
$7 \quad$ Justice for Janitors goes Dutch
}

\author{
Precarious labour and trade union response in the cleaning \\ industry (1988-2012): a transnational history*
}

\begin{abstract}
Precarious labour has been on the rise globally since the 1970 s and 1980 s. Changing labour relations in the cleaning industry are an example of these developments. From the 1970s onwards, outsourcing changed the position of industrial cleaners fundamentally: subcontracting companies were able to reduce labour costs by recruiting mainly women and immigrants with a weak position in the labour market. For trade unions, it was hard to find a way to counteract this tendency and to organize these workers until the Justice for Janitors (J4J) campaigns, set up by the us-based Service Employees International Union (SEIU) from the late 1980s, showed that an adequate trade union response was possible. From the mid-20oos, the SEIU launched a strategy to form international coalitions outside the United States. It met a favourable response in several countries. In the Netherlands, a campaign modelled on the J4J repertoire proved extraordinarily successful. In this chapter, transnational trade unionism in the cleaning industry based on the J4 J model will be analysed with a special focus on the Dutch case. How were local labour markets and trade union actions related to the transnational connections apparent in the rise of multi-national cleaning companies, the immigrant workforce, and the role of the sEIU in promoting international cooperation between unions?
\end{abstract}

Keywords: outsourcing, precarious work, precariat, cleaners, janitors, organizing, transnationalism, regulatory unionism, industrial relations, The Netherlands

* $\quad$ Reprinted from Ad Knotter, 'Justice for Janitors Goes Dutch. Precarious Labour and Trade Union Response in the Cleaning Industry (1988-2012): A Transnational History', International Review for Social History 62(1) (2017), 1-35. The title is borrowed from Connolly, et al., "Justice for Janitors"', https://www2.warwick.ac.uk/fac/soc/wbs/research/irru/publications/recentconf/ hc_buira_2011.pdf. A revised version of this paper has been published in Work, Employment

Knotter, Ad, Transformations of Trade Unionism: Comparative and Transnational Perspectives on Workers Organizing in Europe and the United States, Eighteenth to Twenty-First Centuries. Amsterdam, Amsterdam University Press, 2018

DOI: 10.5117/9789463724715_CHO7 
Making my way through the entrance hall, I cannot keep my eyes off the spotless, shiny marble floor, that seems to reflect an intention of presenting the kind of glamour and pace of economic dynamism that the management here takes such pride in. But the story isn't all that flashy. ${ }^{1}$

SEIU is going to change the world. We are changing the world, for workers anyway [...]. Look, we started in LA, we picked it up in London [...] Look at the Netherlands, it's amazing what we have been able to do there. They were getting their asses kicked and now they're running campaigns. ${ }^{2}$

To the surprise of many observers accustomed to industrial harmony in the Netherlands - epitomized in the so-called poldermodel - low-paid and, until then, mostly unorganized cleaners staged successful strikes in 2010, 2012, and 2014, with the full support of the Dutch trade union FNV Bondgenoten. As a result of these strikes, the cleaners achieved considerable improvements in collective agreements with the cleaning companies. Only insiders knew that these strikes had been carefully prepared and planned by FNV Bondgenoten in close cooperation with the us-based Service Employees International Union (SEIU), ${ }^{3}$ and modelled on the example of the SEIU campaign Justice for Janitors $(\mathrm{J} 4 \mathrm{~J})$ since the late $1980{ }^{4}{ }^{4}$ In this campaign, SEIU had developed a new approach to organizing by hiring a cadre of specialist organizers who

and Society 31 (2017), 319-335. All internet sources for this chapter were consulted between December 2015 and April 2016. My research was greatly helped by conversations with Mari Martens, Ron Meyer, and Eddy Stam, who were responsible for the FNV Bondgenoten cleaners' campaigns in the Netherlands, and with the Maastricht cleaner-activist Tim Edwards. FNV Bondgenoten documentalist Irma van den Bosch provided valuable material. I would also like to thank my honours students Erica Belcher, David Darler, Lisa Hermanns, and Raoul Müller for their engagement and lively discussions.

1 Pai, 'The Invisibles', 164.

2 Valery Alzaga, a Justice for Janitors organizer for the Service Employees International Union (SEIU), interviewed (2010) in McCallum, Global Unions, 48. For a 30-minute interview with Alzaga on organizing tactics and her involvement in Holland, see https://snuproject.wordpress.com/2014/02/21/ organizing-the-unorganizable-justice-for-janitors-an-interview-withvalery-alzaga/.

3 Dutch newspapers reported on the US connection, but it was not known to the public: Esther Bijlo, 'Nieuw. De Doe-het-zelf-actie', Trouw, 17 April 2010; Jurry Brand and Jarco de Swart, 'Vakbond terug naar winderige werkplek', De Telegraaf, 24 April 2010; Elsbeth Stoker, 'Organizer is de spin in het web van de stakingsactie', De Volkskrant, 27 May 2010.

4 'Janitor' is American English for 'cleaner'. Originally, a janitor was a concierge, for whom cleaning was only part of his job: Gold, 'In the Basement'. The research for this article was done in 1949/50. In light of the following, it is remarkable that, according to this author (p. 41), 'Men become janitors, and stay on as janitors, to enjoy economic security.' 
were not general union officers. ${ }^{5}$ The SEIU had been successful in the Justice for Janitors campaigns because of tactics based on the active involvement of newly recruited members. Following this approach, FNV Bondgenoten encouraged self-organization and the formation of leaders at workplace level. Through a combination of grass-roots organizing, direct action, and broad coalitions, the union was able to put pressure on subcontracting cleaning companies and their clients.

In spite of the evidently top-down start of the campaign by FNV Bondgenoten, the organizing model was meant to connect the union with its grass roots by developing focused recruitment campaigns in a bottom-up approach. The cleaners themselves had to be mobilized for active involvement in actions and negotiations. For Ron Meyer, responsible for organizing the campaign on behalf of FNV Bondgenoten, trade union renewal was at the heart of his endeavours:

For too long the union has viewed its members as consumers, and that hasn't encouraged them to get involved. In my view, the image of the union leader shepherding his flock is dead and gone. People have to be clued up on their situation, because they are the only ones who can get things done. Only they can stick up for their rights and go on the front foot. ${ }^{6}$

In my view, these developments have a broader meaning than just the successes of FNV Bondgenoten in mobilizing the cleaners in strikes and other actions to improve working conditions. What is at stake is the ability of low-paid, precarious workers to stand up for their collective rights in an increasingly individualized, flexible, and unfavourable labour market. ${ }^{7}$ The debate on precarious labour and its origins in the neoliberal restructuring of labour markets since the 198 os has been going on for some time. The cleaning industry is an example of these developments. Social scientists have been studying professional cleaning precisely because 'it is paradigmatic for the whole low-skilled service sector in many respects'. ${ }^{8}$ Cleaners used to be part of the labour force in public institutions, manufacturing, banking, transport, and other services, and were covered by collective agreements in these industries. From the 1980s, outsourcing changed the position of cleaners

5 Lerner, 'Let's Get Moving'. Lerner was the SEIU's architect of the Justice for Janitors campaign.

6 Cited in Heuts, “'No More Being Ground Down for Us”, 28-29. See also idem, Tegenmacht; Olders and Van der Velden, Respect!

7 Oudenampsen, 'Precariousness in the Cleaning Business'.

8 Mayer-Ahuja, 'Three Worlds of Cleaning', 116. 
fundamentally: increasingly, they were employed by specialized companies in a separate industry, which continued to grow in an extremely competitive market for cleaning services. In the labour-intensive cleaning industry, reducing labour costs was considered the only way to secure contracts. Subcontracting companies were able to do so by recruiting mainly women and immigrants with a weak position in the labour market. The cleaners' actions, both in the Netherlands and elsewhere in the world, showed that an adequate trade union response was possible to counteract this seemingly inevitable tendency towards precariatization of the labour force. ${ }^{9}$

During the Justice for Janitors campaigns in the United States, the SEIU discovered that, although operating in highly competitive local markets for place-bound cleaning services, subcontracting firms were often part of large multi-nationals. ${ }^{10}$ An example is International Service Systems (Iss Facility Services), one of the largest cleaning companies in the United States and, in fact, the world. It originates from, and is based in, Denmark, but operates on a global scale. ${ }^{11}$ In 2004, the SEIU concluded that 'many members worked for companies that were multi-national. To win members' contracts, we had to campaign at a multi-national level. ${ }^{12}$ At its 2004 Convention, the SEIU launched a strategy to form sustained international coalitions. Exploratory visits were made to several countries in order to select unions for partnership. The union invested significant resources in regional officers and organizers in Australia, Britain, the Netherlands, and other countries. Membership and leadership exchanges were organized to set up campaigns. ${ }^{13}$ One of the aims was to get multi-national employers and their clients to sign on to socially responsible contractor global agreements. Union Network International (UNI, now UNI Global Union), the global union federation for services, succeeded in signing such a contract with ISs as a framework within which national branches could negotiate with cleaners' unions. ${ }^{14}$ Cooperation with FNV Bondgenoten was thus part of a deliberate strategy by the SEIU to transnationalize trade unionism in the cleaning sector. Comparable campaigns were set up with partners in

9 Alzaga, 'Justice for Janitors Campaign'.

10 Lerner, 'Global Corporations, Global Unions', repr. in Goodwin and Jasper (eds), The Social Movements Reader.

11 In 2004, it operated in 43 countries, with more than 200,000 employees worldwide: Lerner, 'Global Unions', 29 (based on ISS Annual Report 2004). See also http://www.issworld.com/.

12 SEIU vice-president Tom Woodruff, cited by Tattersall, 'Labor-Community Coalitions', 161.

13 Ibid., 167; Aguiar and Ryan, 'The Geographies of the Justice for Janitors', 952.

14 Personal communication from Mari Martens, 5 February 2016, and Eddy Stam, 15 April 2016; Alzaga, 'Justice for Janitors Campaign'. See also http://www.ewcdb.eu/docs/9231. 
London ('Justice for Cleaners'), in Australia and New Zealand ('Clean Start'), and on a smaller scale, partly inspired by the Dutch example, in Germany ('Ich Putze Deutschland'). ${ }^{15}$

This chapter aims to analyse transnational trade unionism in the cleaning industry between the start of the Justice for Janitors campaign in Los Angeles in 1988 and the Dutch cleaners' strike in 2012 in the context of the debate on precariousness and neoliberal restructuring of labour markets since the 1980 . By developing new forms of organizing, the sEIU, followed by trade unions in the Netherlands, Britain, Australia, and elsewhere, found ways to combat the effects of the restructuring of cleaning services on local and national labour markets. How were these local labour markets and trade union actions related to the transnational connections apparent in the rise of multi-national cleaning companies, the immigrant workforce, and the role of the SEIU in promoting international cooperation between unions? Or, to put it in more fashionable terms, how was the 'local' connected to the 'global'? A comparison of campaigns in Los Angeles, London, Australia, and Canada, and a more detailed analysis of the Dutch case, will show that ultimately the transnationalism of cleaners' unionism had its limits: the example set by Justice for Janitors in the United States and the support of the sEIU helped in getting campaigns off the ground, but in the end unions had to act locally or nationally to force employers to accept the regulation of wages and working conditions.

After a general introduction to precariousness and the trade union response to labour market restructuring and its impact on the cleaning industry since the 1970s and 1980s, these issues will be researched, firstly by analysing developments in Los Angeles, where the Justice for Janitors campaigns in the 1990s had inspired not only filmmaker Ken Loach to produce the award-winning feature film Bread and Roses, but also 'a mountain of academic studies', ${ }^{16}$ which could be used in analysing the Los Angeles case. Then I will describe the export of the Justice for Janitors model to the rest of the United States, Britain, Australia/New Zealand, and Canada. Finally, I will focus on the cleaners' strikes in the Netherlands to see whether what we have found out about the cleaners' actions in Los Angeles and elsewhere can be helpful in understanding the Dutch case.

15 Fontana, 'A Comparative Analysis', 55-68, https://opus4.kobv.de/opus4-hwr/frontdoor/index/ index/docId/49; Bremme, Fürniß, and Meinecke (eds), Never Work Alone; Vandaele and Leschke, 'Following the "Organising Model"', https://www.etui.org/Publications2/Working-Papers/ Following-the-organising-model-of-British-unions.

16 McCallum, Global Unions, 49 . 


\section{Precarious labour and trade union response}

The concept of precariousness entails instability, lack of protection, insecurity, and economic vulnerability. Precarious work can be defined as uncertain, unpredictable, risky, and low-paid. As such, precarious employment is not new: it has been an integral part of the experience of wage labour, both historically and globally. To reduce uncertainty in the labour market, the trade union movement tried, from its origins in the nineteenth century, to conclude collective agreements to regulate employment relations, and demanded social security measures and protective labour laws from the state. During the phase of steady economic growth between the end of the Second World War and the mid-1970s, forms of labour market regulation and protection of regular jobs came to dominate the industrial system in Western or Westernized capitalist countries. Full-time, permanent, on-site waged employment became the 'standard employment relation', albeit predominantly for the male part of the workforce.

Since the last quarter of the twentieth century, however, the full-time permanent jobs that were the hallmark of economic growth after the Second World War have been in decline. Everywhere, there is a shift towards flexible labour, part-time jobs, fixed-term contracts, self-employment by nominally independent contractors, and temporary or agency work, producing an increasing precariousness of employment. ${ }^{17}$ The erosion of the standard employment relation since the economic crisis of the mid-197os was a consequence of increasingly competitive pressures on companies in globalizing markets to reorganize in more flexible ways. As a result, employment relations became more diverse. Former International Labour Organization official Guy Standing even detected a new, separate class of precarious workers, to which he applied the neologism 'precariat' (from 'precarious' and 'proletariat'). ${ }^{18}$ These developments have been underpinned by neoliberal approaches in socio-economic regulation and policy-making.

Historically, trade unions have been important in the drive towards labour market regulation and social protection. Conversely, the growth

17 Thornley, Jefferys, and Appay (eds), Globalization and Precarious Forms; Kalleberg, Good Jobs, Bad Jobs, 24-26. See also idem, 'Precarious Work, Insecure Workers'.

18 Standing, The Precariat. For a critique, see Wright, Understanding Class, ch. 9; see also idem, 'Is the Precariat a Class?' The neologism précariat to designate people in a precarious position as a specific social group or 'class' originated in France: Schreuer, 'Qu'est-ce-que le précariat?' See also Barbier, 'La précarité'. For a recent evaluation, see della Porta, et al. (eds), The New Social Division. 
Figure 7.1 Film poster of Bread \& Roses, the film about Justice for Janitors (J4J) in Los Angeles by Ken Loach, produced by Rebecca O'Brien, and written by Paul Laverty (2000)

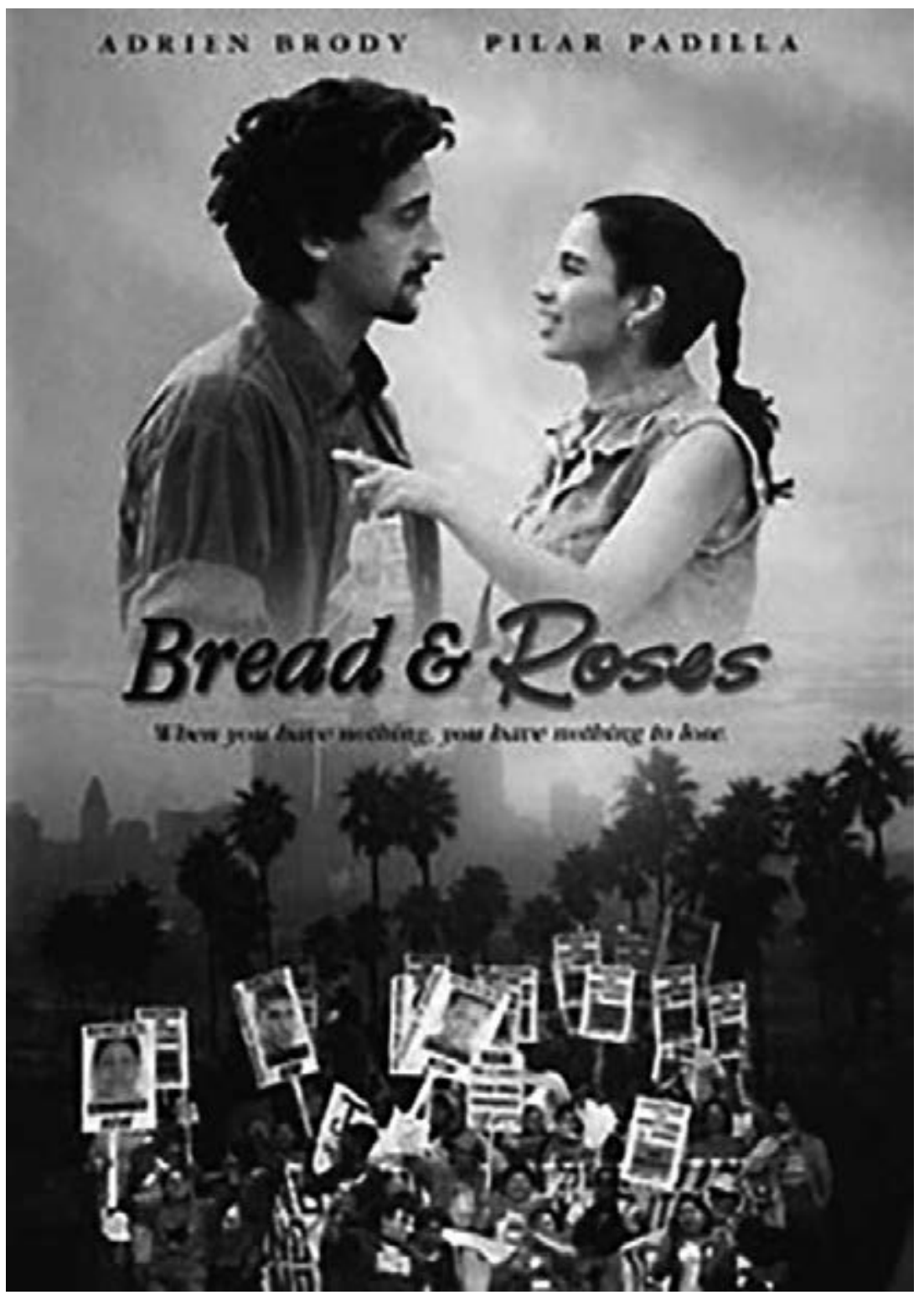

Used with permission of Sixteen Films 
of precarious labour in the last quarter of the twentieth century was closely related to the weakening of trade unions in that period, expressed in terms of both union membership and density. Insecurity in its various manifestations increased because the protective shield of trade unionism was removed. ${ }^{19}$ Some, however, tend to blame the unions themselves for this decline, because of their inability to organize and represent the 'precariat'. In this view, the trade union movement represents only core workers, whose numbers are declining and whose interests are fundamentally different from those of precarious workers. ${ }^{20}$ In some countries, particularly Italy, Spain, and France, precarity is used to mobilize people outside union organizing and beyond the workplace. When work is constantly changing, so the argument goes, it makes little sense to organize around it. ${ }^{21}$

Nevertheless, trade unions are becoming increasingly aware of the dangers of deregulation and flexibilization of labour markets, also for core workers. For Europe, this is becoming apparent from the reports of the EU-funded research projects 'Bargaining for Social Rights' (BARSORI), and its successor 'Bargaining for Social Rights at a Sectoral Level' (BARSORIS), coordinated by the Amsterdam Institute for Advanced Labour Studies (University of Amsterdam) $\cdot{ }^{22}$ European unions have begun serious efforts to extend trade unionism to the insecure workforce, to recruit 'outsiders' with precarious, low-paid jobs, with the aim of improving their employment conditions. ${ }^{23}$ Of special interest in the context of the cleaners' campaigns are attempts to recreate trade unions as social movements, with the purpose of mobilizing members and supporters against injustice at work. In a number of cases, organizing workers in precarious jobs in this way has worked quite well. ${ }^{24}$ The BARSORI and BARSORIS country reports on the UK, the Netherlands, and Germany all invoke the campaigns to mobilize cleaners as examples of attempts at organizing precarious workers.

19 Heery and Abbott, 'Trade Unions and the Insecure Workforce'. On the United States, see Kalleberg, GoodJobs, BadJobs, 31-34.

20 This seems to be Standing's position: Standing, A Precariat Charter.

21 Arnold and Bongiovi, 'Precarious, Informalizing, and Flexible Work', 299.

22 Reports on both projects for each country (Denmark, Germany, Italy, the Netherlands, Slovakia, Spain, United Kingdom) can be found on the project websites: BARSORI, http://archive. uva-aias.net/361, and BARSORIS, http://archive.uva-aias.net/426.

23 Keune, 'Trade Union Responses', 66; idem, 'Trade Unions, Precarious Work and Dualisation in Europe'.

24 Heery and Abbot, 'Trade Unions and the Insecure Workforce', 163-170. 


\section{Subcontracting, cleaning, and precariousness: a global development}

Studies on the development of the cleaning industry in a range of countries invariably show that since the 1970s/1980s outsourcing has resulted in an increasing number of jobs in subcontracting firms subject to competitive tendering. The process of tendering caused insecurity of employment as well as a potential reduction in wages and entitlements. For subcontracting firms, the key issue was to retain and increase the number and size of contracts. The costs of labour and the conditions under which it was employed were crucial elements in the bidding process. Periodic reviews of terms and conditions of contracting generated uncertainty about future work relationships and the spread of precarious employment.

The shift to contracting out cleaning to specialized companies in the last quarter of the twentieth century and its deleterious effects on working conditions have been documented for Israel, ${ }^{25}$ the United States, ${ }^{26}$ Britain, ${ }^{27}$ Canada, ${ }^{28}$ Australia and New Zealand, ${ }^{29}$ Germany, ${ }^{30}$ France, ${ }^{31}$ Belgium,,${ }^{32}$ and other countries. ${ }^{33}$ Everywhere, there has been an increase in outsourcing to a growing number of cleaning companies. The organization of employment in these companies is based on a quest for maximum flexibility. Subcontracting enhances the competition among companies and results in a race to the bottom in production costs. To find people prepared to work in these conditions, the cleaning sector has to draw its workforce from the most vulnerable segments of the labour force: female and immigrant workers are hugely overrepresented in every country. However, for these people, to find a job in the cleaning sector can also be a means to gain access to the labour

25 Bernstein, "The Subcontracting of Cleaning Work in Israel'.

26 Howley, 'Justice for Janitors'; Mines and Avina, 'Immigrants and Labor Standards'; Cranford, 'Gender and Citizenship'; idem, 'Economic Restructuring'.

27 Coyle, 'Going Private'; Rees and Fielder, 'The Services Economy'; Allen and Henry, 'Ulrich Beck's Risk Society at Work'; idem, 'Fragments of Industry and Employment'; Wills, 'Making Class Politics Possible'.

28 Aguiar, 'Restructuring and Employment Insecurities'.

29 Brosnan and Wilkinson, 'Low Pay and Industrial Relations'; Ryan and Herod, 'Restructuring the Architecture of State Regulation'; Campbell and Peeters,'Low Pay, Compressed Schedules'; Holley and Rainnie, 'Who Cleans Up?'

30 Mayer-Ahuja, 'Three Worlds of Cleaning'.

31 Munar Suard and Lebeer, 'Nature et contenus de la relation de sous-traitance'; Denis, 'Dans le nettoyage', 100-101; Connolly, 'Organizing and Mobilizing Precarious Workers'; Nizzoli, C'est du propre!

32 De Troyer, Lebeer, and Martinez, 'La précarité des ouvrières du nettoyage en Belgique'. 
market, and even a starting point of emancipation by collective action. That is the story of the predominantly Latino and Latina janitors in Los Angeles in the 1980 s and 1990s. Their keen desire for economic advancement made them ready to act collectively, once offered opportunities to do so.

\section{Lessons from LA}

Latino rank-and-file workers have made the Los Angeles area the major R\&D center for 21st-century trade unionism. ${ }^{34}$

Contemporary observers considered the Justice for Janitors campaign in Los Angeles 'the single most important organizing success of the us labour movement in the late twentieth century'. ${ }^{5}$ Led by union organizers sent by SEIU headquarters in Washington, DC, the campaign was set up in 1988, following earlier successful rallies of this kind in Denver (1986) and Washington, DC $(1987) \cdot{ }^{36}$ It relied on a variety of unorthodox tactics designed to put pressure on owners and managers of client companies, also by mobilizing bystanders and sympathizers from the broader community. In 1989, the union decided to focus on a large, newly built office complex in Los Angeles, called Century City, employing 400 janitors, of whom 250 were with the cleaning contractor ISs. In May 1990, a strike was called, and not long afterwards an agreement was signed with the largest cleaning companies ISS and ABM, later to be extended to smaller firms. A second round of negotiations took place in 1995. The result was a five-year agreement. With contract renewal in 2000 in sight, the SEIU local began to prepare its members for mass protests by 'internal organizing'. A strike in April was accompanied by dramatic street protests, daily rallies in public places, and efforts to get media attention and put pressure on major players in the industry. Again, the big cleaning companies proved willing to concede, and overruled the more intransigent smaller firms. The strike was settled at the end of its third week, in a widely celebrated victory for the union. The new three-year contract included a 25 per cent pay raise as well as greatly improved health benefits. In the 2003

Davis, Magical Urbanism, 170; see also Milkman, LA Story.

35 Erickson, et al., 'Justice for Janitors in Los Angeles', 544; idem, 'Justice for Janitors in Los Angeles and Beyond'; Bridges, 'The Sun Also Rises in the West'; Waldinger, et al., 'Helots No More'.

36 Lerner, Hurst, and Adler, 'Fighting and Winning in the Outsourced Economy', 249; Williams, 'Restructuring Labor's Identity'. For a digital history of Justice for Janitors in Washington, DC, see http://www.georgetownlaborhistory.org/. 
Figure 7.2 Downtown rally by Justice for Janitors in Los Angeles, 1990: 'Union demonstrators who marched around the downtown high rise buildings where they rallied for better contracts end with skit of character of a greedy contractor who pays poor wages for cleaning services.'

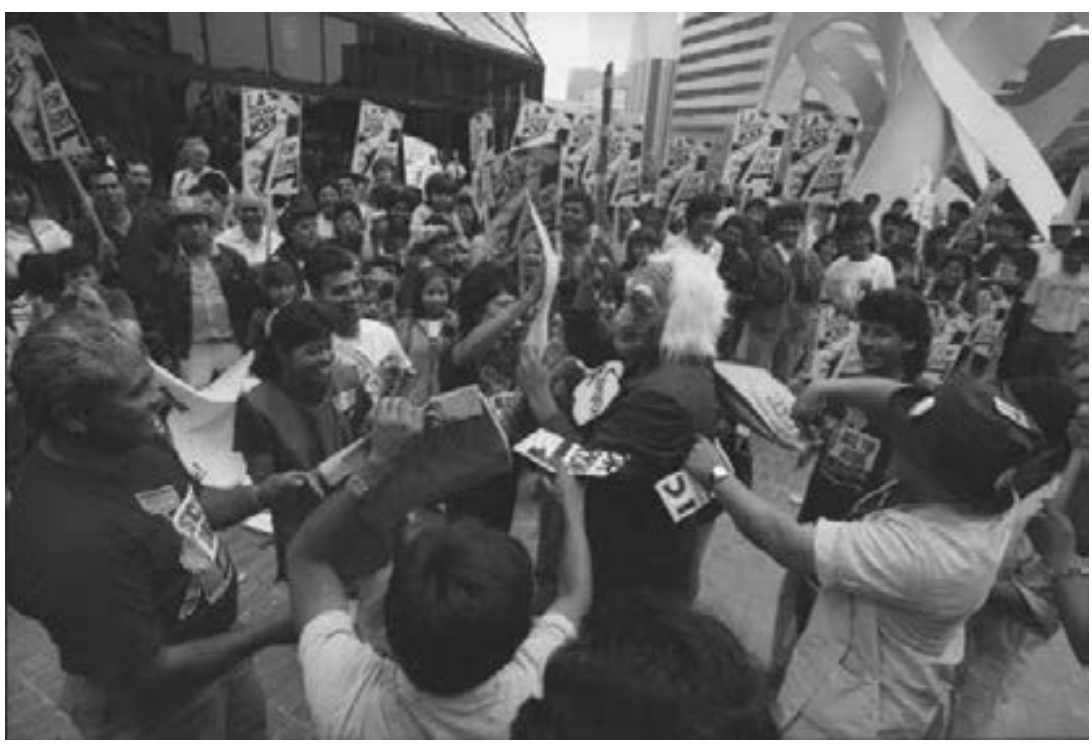

ucla Library Special Collectons: Los Angeles Times photo archive, coll. 1429. Photograph by Mike Sergieff. Used with permission

contract, the SEIU's janitors made still further gains, this time without a strike. Between 1988 and 1995, the SEIU organized more than 8,00o janitors in $\mathrm{LA} ;{ }^{37}$ the settlement in 2000 added another $5,000 .^{38}$

Justice for Janitors unionism was constructed as a broader politics of social justice for the community as a whole. By legal action, symbolic representation, and direct confrontation in street protests, the campaign was targeted at building owners, to press them to take responsibility for the welfare of janitors who were formally employed by the cleaning contractors. To bring their otherwise invisible presence into the open, groups of protesting cleaners and their allies occupied public spaces (streets, intersections, and pavements), picketed building entrances, and invaded properties of building owners. Public appearances were accompanied by speeches, flyers, street theatre, and other means of symbolic communication. Publicity stunts 318.

38 Milkman, LA Story, 160. 
staged to draw attention to the janitors' plight were highly effective in publicly embarrassing powerful players in the industry, while also making life difficult for building tenants. ${ }^{39}$ The cleaners' cause was presented as an issue of social justice for the underprivileged in general, in contrast to the privileges and the wealth of the owners and occupiers of the glittering high-rise offices where they did their job. In this way, they were able to garner sympathy and moral support from the wider community, religious leaders, and politicians. ${ }^{40}$

Mass mobilization combined with labour, religious, and political support pressed the building owners to call upon contractors to negotiate with the union and reach an agreement. While this kind of symbolic power may have been an effective avenue for the low-skilled cleaners with limited structural power in the labour market of their own, ${ }^{41}$ its widespread use in the Justice for Janitors campaign is not enough to explain the willingness of the cleaning companies to concede. In LA Story, her account of the city's trade union history, Ruth Milkman draws attention to the tradition of the American Federation of Labor (AFL), to which the SEIU belonged, of 'regulatory unionism': AFL unions focused their organizing efforts on decentralized, highly competitive industries, with the aim of stabilizing local or regional labour markets in these industries by 'taking wages out of the competition'. ${ }^{22}$ 'Regulatory unionism' meant that unions put pressure on employers to recognize that strong unions and uniformly negotiated wages could serve as a means of regulating labour costs across an industry, especially in disorganized industries otherwise unable to achieve market stability. Strong unions and collective agreements were used to equalize labour costs and to discipline or eradicate marginal competitors. ${ }^{43}$

The Justice for Janitors campaign managed to restore labour market regulation based on union power. To exercise union leverage on all key players in the local labour market so as to effectively take wages out of

39 Ibid., 157 .

40 Cranford, 'Gendered Resistance', 320-323. The campaign also rallied support from well-known UCLA academics, such as the geographers Mike Davis and Edward Soja, who encouraged their students to join and helped develop a new generation of union researchers: Alzaga, 'Justice for Janitors Campaign', 2.

41 Jihye Chun, Organizing at the Margins.

42 Milkman, LA Story, 74-75. Industrial organizing by the Congress of Industrial Organizations (CIO, later to be merged with the AFL into the American trade union federation AFL-CIO) focused primarily on highly concentrated, oligopolistic industries (such as the automobile industry), where wage competition was not at issue. The term 'regulatory unionism' was introduced by Gordon, New Deals.

43 Ibid., 87-97. 
competition had been the explicit goal of Stephen Lerner, its key architect. ${ }^{44}$ The SEIU strived for arrangements whereby the local union could control the terms and conditions that would prevail across the local labour market as a whole. ${ }^{45}$ To realize this, the union tried to win companies willing to negotiate over to its side: after a contractor reached an agreement with the union, the SEIU would not raise wages until a majority of its competitors had decided to follow, ensuring that no contractor was put at a competitive disadvantage. ${ }^{46}$ This strategy forestalled the problem of making a union contractor uncompetitive in a market shaped by labour costs. No contractor was disadvantaged by the extra costs of higher wages and benefits. ${ }^{47}$

This strategy could be successful because cleaning as an economic activity is place-bound and, despite being dominated by global corporations, largely immune from the effects of capital mobility. The large, global cleaning companies had to compete locally with small or medium-sized firms, which had easy access to the local market and could offer their services at lower costs (cleaning does not require large investments or specific skills). For this reason, the large companies had an interest in regulating the labour market by taking wages out of the competition. To put this into effect, however, they needed a strong union to enforce a contract that did just that. This explains the willingness of the larger firms to reach an agreement and force this upon the smaller ones in both the 1990 and the 2000 campaigns. Moreover, for building owners, the costs of the settlement were marginal, and for them it was easy to adapt the contracts with the clients once an industry-wide agreement had been reached.

All this had been deliberately aimed at in the Justice for Janitors campaign: the SEIU's strategists reasoned that, if agreement could be reached with the big players ABM and ISs, other smaller contractors would follow, and LA's major office centres could be brought under a union contract. To enforce the willingness of the major contractors in the 2000 strike, however, the SEIU had to transcend the locality of the labour market and put pressure on their business elsewhere in the United States by picketing buildings cleaned by these same companies in other cities. ${ }^{48}$ In what seemed to be a local affair, the union concluded that it could reach an agreement with the big cleaning companies more easily by turning to the grander scale of the national and, some years later, the global.

44 Milkman, LA Story, 152, 156; idem and Voss, 'New Unity for Labor?', 19.

45 Howley, 'Justice for Janitors', 67.

46 Lerner, 'Global Corporations, Global Unions', 338; Erickson, et al., 'Justice for Janitors in Los Angeles', 554 .

47 Luff, 'Justice for Janitors', 730.

48 Erickson, et al., 'Justice for Janitors in Los Angeles', 548, 554. 


\section{Export of the Justice for Janitors model}

Following the successes of the Los Angeles strikes, Justice for Janitors campaigns were launched in a range of cities around the United States. The SEIU tried to raise standards for janitors by confronting owners and their contractors on a national basis. Campaigns routed contractors across the country, winning sizeable wage increases and health-care benefits. 49 Its biggest victory was in Houston in 2006, in the heart of Republican and anti-union Texas, where the predominantly Latino immigrant janitors eventually secured a contract doubling their income and gaining health benefits after a month-long strike..$^{0}$ In ten different cities across Europe and Latin America, the SEIU organized support for the Houston strike with allied unions and social movement organizations..$^{1}$

By then, the SEIU had already decided to go global, and the international solidarity campaign for the Houston strikers was part of its global action model..$^{2}$ The SEIU sought to marshal a great number of allies in order to shape the terms of the global cleaning industry. After its 'Global Strength' commitment at its 2004 national convention, a 'global partnership unit' was founded by the union in November 2004, firstly to coordinate campaigns with a global scope, secondly to foster partnerships with unions in other countries to build global union power, and thirdly by providing experienced staff and support for organizing drives with partner organizations. ${ }^{53}$ Relationships were established through exploratory visits to other countries, including Australia, the United Kingdom, the Netherlands, and Germany, to discuss new forms of alliances and to find partners with a commitment to the organizing model. ${ }^{54}$ Many of the SEIU's global relationships (with the UK union Unite and FNV Bondgenoten, for example) began in the Union Network International (UNI), which was officially founded in 2000 following a merger of a number of international unions in the services industry, and in which the SEIU played a prominent role. 55

49 For an overview, see Luff, 'Justice for Janitors', to be supplemented by Lerner, et al., 'Fighting and Winning in the Outsourced Economy'; see also Rudy, “Justice for Janitors"', and Albright, 'Contending Rationality'.

$5^{o}$ Bracey, 'Interracial Political Coalitions', http://oaktrust.library.tamu.edu/bitstream/ handle/1969.1/ETD-TAMU-3247/BRACEY-THESIS.pdf?sequence=1.

51 Alzaga, 'Justice for Janitors Campaign'; Lerner, 'Global Corporations, Global Unions'.

$5^{2}$ 'Organise Local, Strike Global', http://turbulence.org.uk/turbulence-1/organise-local-strikeglobal/.

53 Tattersall, 'Labor-Community Coalitions', 162-163.

54 Ibid., 167; Aguiar and Ryan, 'The Geographies of the Justice for Janitors', 952.

55 McCallum, Global Unions, 70-71. 
The SEIU chose to connect with unions that had already started or participated in organizing cleaners. In 2005, SEIU organizers were seconded to the British Transport \& General Workers Union (TGWU) to set up a Justice for Cleaners campaign in London, where financial companies at Canary Wharf had already been targeted successfully..$^{56}$ The arrival of SEIU strategists in 2005 prompted the TGWU to dramatically step up its campaign. A multi-lingual team of organizers, many of them ex-cleaners from Canary Wharf, was formed to work on the campaign, which extended to the Houses of Parliament and the City of London. By 2009, around 3,000 cleaners had been recruited as members of the union (now called Unite), and agreements were signed with the major cleaning contractors, including Iss. As in the United States, immigrants were hugely overrepresented among cleaners in London, and a remarkable 35-40 per cent of participants in the London Justice for Cleaners campaign were Latin Americans. ${ }^{57}$

Like the one in Los Angeles, the London campaign was a clear example of 'regulatory unionism'. Drawing on the lessons of Justice for Janitors in the United States, the TGWU tried to regulate the market by targeting the largest contractors across areas in a 'zonal approach'. Pay rises for around 4,00o cleaners across Canary Wharf and the City of London were to be met by the clients, and the union strategy was designed to prevent any retendering from eroding the agreed terms and conditions. In the extremely competitive market for cleaning services, cleaning contractors recognized that they had a material interest in getting clients to pay more for good-quality cleaning, and that they were caught in a vicious cycle of competition that was not in their interest. As Jane Wills remarked in her analysis of the London campaigns, this situation provided fertile ground for the TGWU to develop relationships with parts of the cleaning industry and industry-wide bodies in support of organizing campaigns. In regulating wages and organizing the industry, they found common ground in increasing training and professionalism as well as in improving the pay and conditions of work..$^{8}$

Another SEIU partnership that succeeded was with the Australian Liquor Hospitality and Miscellaneous Union (LHMU) and the New Zealand Service and Food Workers Union (SFWU). Under the slogan 'Clean Start: A Fair Deal

56 Ibid., 62. On the London campaigns see also Holgate, 'Unionising the Low Paid in London', https://www.ilr.cornell.edu/sites/ilr.cornell.edu/files/Justice-for-Janitors-Case-Study.pdf; Wills, 'Making Class Politics Possible', 312-313; Scandella, 'Tel un phénix renaissant des poussières'.

57 Hearn and Bergos, 'Latin American Cleaners Fight for Survival', 67 and 70.

$5^{8}$ Wills, 'Making Class Politics Possible', 315-316. 
for Cleaners', in 2006 these unions started a campaign to organize cleaners. ${ }^{59}$ The SEIU sent organizers and research staff to Australia, some of whom had been involved in the Houston strike shortly before.$^{60}$ Like everywhere else, the Australian and New Zealand cleaners were precarious workers from a predominantly non-English speaking immigrant background; 6o per cent were women. Some 50 organizers set up committees in the ten largest cities in Australia and New Zealand to mobilize the cleaners.

The campaign won wage increases of one-third and improvements in job security ${ }^{61}$ Again, regulating the industry was a primary goal of the campaign. The LHMU presented itself as working in the interests of the cleaning contractors and building owners: it was 'aiming to achieve what the cleaning contractors have been unable to - a fair price. In the union's view, a fair price is one where building owners and managers engage cleaning firms on contracts that enable them to act as a responsible employer and enjoy some profit margin. ${ }^{62}$ One of the first to understand this logic was Iss, one of the biggest cleaning companies in Australia as well: "They identified very quickly that the crisis identified by the union was a crisis that undermined their ability to make money in the market. Tenders were continually undercut by contractors cutting labour costs. ${ }^{63}$

Also in 2006, the sEIU extended its Justice for Janitors campaign into Canada, at first in Toronto, later also in cities such as Ottawa and Vancouver, and at the University of Alberta (Edmonton). ${ }^{64}$ In Canada, the SEIU did not seek partnership with a cleaning union as it was the de facto cleaning union in the country (since the 1940s; it justifies the 'I' of 'International' in the acronym SEIU). In 2006, the SEIU Toronto local began a campaign to organize cleaners, and, as of August 2009, more than 2,000 of them had been organized. Cooperation with other unions representing cleaners led to citywide agreements with four of the five largest companies in the Toronto market. $^{65}$

59 Crosby, 'Clean Start'.

6 Idem, Power at Work, 5; McCallum, Global Unions, 58.

61 Ibid., 58-61; Cleaners and Community United for Justice (n.p., n.d.), http://sfwu.org.nz/files/ LO105_CS_Com_Broc_Final_R\%20(2).pdf.

62 Aguiar and Ryan, 'The Geographies of the Justice for Janitors', 955.

63 Crosby, 'Clean Start', 142.

64 For the Alberta case, see Foster and Barnetson, 'Justice for Janitors in Alberta'.

65 Aguiar and Ryan, 'The Geographies of the Justice for Janitors', 953-954. 


\section{Becoming visible}

Socially, the act of cleaning is invisible, despite the importance of the visibility of its results. Cleaning is often scheduled outside office hours so as not to coincide with normal activities. The spatial and temporal segregation of the workers, working conditions, and the unseen nature of the work tend to erase all traces of the presence of a cleaning workforce, unless, of course, the cleaning is not done or perceived as poorly done. ${ }^{66}$ The issue of 'visibility' became a recurrent theme in the cleaners' campaigns. Its resonance among the cleaners was an important element in the organizing drives everywhere. Interviewed about her motivation to become a shop steward in her workplace in Toronto, a Portuguese cleaner named Paula mentioned the invisibility of her work: 'You know, the big bosses I heard got a bonus. But the cleaners, nobody stop and say thank you to you [...]. So, it's like they not see you. You are invisible.' The interviewers conclude 'that the emotional cost of invisibility for workers, who feel unrecognized as cleaners, is partially mitigated for some through their visibility as active union members' ${ }^{67}$

Miami Justice for Janitors campaigner Feliciano Hernandez concluded in 2006: 'We are no longer invisible. Before, our voice was a whisper. Now when we say we will stand up for our rights, our voice is loud and strong enough to be heard. ${ }^{68}$ Workers unionizing in Justice for Cleaners in London 'felt invisible', like 'ghost workers'. ${ }^{69}$ For the Latin American cleaners involved in the University of London campaign in 2008, achieving 'visibility' was at least as important as 'bread and butter gains': 'Now we are not invisible anymore. Thanks to the campaign, people think differently about us. ${ }^{70}$ During the German strike in 2009, the slogan 'Die Unsichtbaren Sichtbar Machen' ('Making the Invisible Visible') was added by Berlin strikers to the original union's slogan 'Ich Putze Deutschland', and after a while it was taken up throughout the sector. ${ }^{11}$

From the start in 2006, the invisibility of the cleaners was a central issue in the Dutch campaigns too. The cry 'Nooit Meer Onzichtbaar' ('Never Again

66 Allen and Henry, 'Ulrich Beck's Risk Society at Work', 189; Pai, 'The Invisibles'; Scandella, 'Travail invisible'; Recio and Godino, 'Invisible Workers', http://www.walqing.eu/fileadmin/download/ external_website/publications/WALQING_socialpartnershipseries_2011.17_Cleaning_SP.pdf.

67 Soni-Sinha and Yates, “'Dirty Work"?', 738 and 745 .

68 Cited in Lerner, et al., 'Fighting and Winning in the Outsourced Economy', 255.

69 Wills, 'Making Class Politics Possible', 317.

70 Interview with Eduardo (2008), cited in Hearn and Bergos, 'Latin American Cleaners Fight for Survival', 73 .

71 German organizer Peter Riedel, cited by Fontana, 'A Comparative Analysis', 57-58. 
Invisible') dates from this early period, and was heard at every rally during the strikes in 2010 and 2012, next to the slogan 'Wat willen we? Respect! Wanneer willen we het? Nu!' ('What do we want? Respect! When do we want it? Now!'). ${ }^{72}$ The cleaners argued that low wages and dismal working conditions were closely related to their invisibility and to a lack of respect for their work. ${ }^{73}$ Judy Lock, a toilet cleaner at Schiphol Airport and one of the most prominent leaders in the Dutch 2010 campaign: 'It is very strange that people walking by just don't see you. That you are invisible. Only when we came into the open with public protests did people become aware of our presence. ${ }^{74}$ And after the 2010 strike cleaner Bert Kuiper remarked: 'What we achieved is respect as a human being, and appreciation for our work. [...] We are no longer invisible. 75

\section{Start of the Dutch campaign at Schiphol Airport}

Dutch cleaning presented all the characteristics of the industry described above.$^{7}$ The market was saturated with thousands of small firms, but dominated by a small number of large companies. In 2011, the largest was (unsurprisingly) Iss Cleaning Services. The five largest companies represented 49 per cent of the total workforce employed in the cleaning business (see Table 7.1). The industry was highly diversified: 62 per cent of firms $(6,345)$ comprised self-employed without personnel (most of them were window cleaners); 29 per cent $(3,010)$ were very small, with 2-10 employees; 8 per cent (835) employed 10-100 cleaners; and only 1 per cent (70) employed more than 100. As everywhere, women were overrepresented in the workforce at 68 per cent; 46 per cent of the workforce were of non-Dutch descent (both first- and second-generation migrants). The turnover of staff was very high:

72 To be heard in YouTube video clips made of most of these rallies. The slogan was clearly copying those used in the US Justice for Janitors campaigns: 'What do we want? Justice! When do we want it? Now!'

73 Marijnissen, 'Met één hand kun je niet klappen', 30-31, http://www.scriptiesonline.uba.uva. $\mathrm{nl} /$ document/112071.

74 Interviewed in Heuts, Tegenmacht, 25.

75 'Nooit meer onzichtbaar', De Poetser. Ledenblad voor schoonmakers in Nederland (October 2010), 7 .

76 The cleaners' campaigns are documented in photos made on almost every occasion by Rob Nelissen (published online, http://mediabank.fnv.nl/) and in YouTube video clips. I consulted these as a source to find out about events during the campaigns and their exact dates (see appendix). Ron Meyer allowed me to use his collection of newspaper articles about the campaigns. These are referred to in the notes. 
35,000-40,000 new cleaners had to be recruited each year. Many cleaners had part-time jobs, which were often combined to earn a living: 27 per cent had contracts of less than 11 hours a week; 30 per cent worked between 12 and 23 hours a week. 77

Table 7.1 The five largest cleaning companies in the Netherlands, 2011

\begin{tabular}{llrr}
\hline Company & Headquarters & Turnover & Workforce \\
\hline iss Cleaning Services & De Meern & $€ 313,200,000$ & 15,200 \\
csu Cleaning Services & Uden & $€ 268,000,000$ & 13,900 \\
Hago Nederland (Vebego) & Voerendaal & $€ 265,700,000$ & 10,135 \\
Gom schoonhouden (Facilicom) & Schiedam & $€ 212,800,000$ & 9,095 \\
Asito & Almelo & $€ 209,800,000$ & 9,566 \\
Total & & $€ 1,269,500,000$ & 57,896 \\
Cleaning industry as a whole & & $€ 3,560,000,000$ & 119,200 \\
\hline
\end{tabular}

Sources: 'Marktoverzicht schoonmaakbranche 2012', Service Management 3 (March 2013), available at http://www.mbcf.nl/wp-content/uploads/2013/02/Service-Management-markoverzicht-2012. pdf; uwv, De Schoonmaak.Sectorbeschrijving (2013)

The cleaning companies were engaged in fierce competition. They had to cut prices to win contracts. Grasping the opportunities of the saturated market, and not being held back by any regulation, clients were inclined to pay less and less. In 2012, a report on the cleaning sector by the Dutch bank ABN AMRO signalled a fragmentation of the market because of the growth in the number of small firms, and the diminishing loyalty of clients, who easily switched contractors: 'Cleaning companies have no market power. Existing contracts are regularly terminated in order to economize in terms of conditions and prices. Consequently, companies have to clean more square metres in substantially less time, and pressure on employees is rising. ${ }^{78}$ Often specialized mediators or brokers were used to find the most profitable contractor. Frequent changes of contractor caused uncertainty for cleaners, and often also deteriorating working conditions. For the union, the only way out of this vicious circle was to build countervailing power in the labour market by organizing and mobilizing cleaners to put pressure on both clients and contractors.

77 UWV, De Schoonmaak: Sectorbeschrijving (2013) 9, 18, http://www.uwv.nl/overuwv/Images/ Sectorbeschrijving_schoonmaak_20130716.pdf.

78 ABN AMRO, Brancherapport schoonmaakbedrijven 2012, https://www.abnamro.nl/nl/images/ Generiek/PDFs/o2o_Zakelijk/o2_Sectoren/Zakelijke_dienstverlening/zakelijkedienstverleningbranche-schoonmaakbedrijven.pdf. 
By the 199os, the forerunner of FNV Bondgenoten, the Industriebond FNV, had already concluded that existing collective agreements in the cleaning branch did not protect workers effectively. However, attempts to organize cleaners in a number of companies in 1992-1993 had met with disappointing results. ${ }^{79}$ In the early 2000s, FNV Bondgenoten officials Mari Martens and Eddy Stam, responsible for the cleaning sector, learned about the Justice for Janitors campaigns through the film Bread and Roses by Ken Loach about Justice for Janitors in Los Angeles, and through their contacts with the SEIU in Union Network International (now UNI Global Union), the global union federation for services. They managed to convince FNV Bondgenoten to cooperate with the SEIU. ${ }^{80} \mathrm{FNV}$ policy adviser Dirk Kloosterboer wrote a report on the innovative organizing strategies of the SEIU and its Justice for Janitors campaigns. ${ }^{8}$ Martens undertook a training course in organizing in the United States and was tasked with bringing the approach back to the Netherlands. He also participated in the Justice for Janitors campaign in Houston in 2006. ${ }^{82}$ On behalf of the SEIU, experienced activists, among them the Valery Alzaga cited at the start of this chapter, came to Amsterdam to coach Dutch union organizers. ${ }^{83}$ Four organizers were hired and trained to do the job in the Netherlands. Two of them were sent to London to participate in the Justice for Cleaners campaign there. ${ }^{84}$

In 2006, FNV Bondgenoten started an organizing campaign among cleaners in The Hague and at Schiphol Airport. ${ }^{85}$ Because of a lack of success in The Hague, in 2007 it was decided to discontinue the organizing efforts there and to concentrate organizing on Schiphol. ${ }^{86}$ This is reminiscent of the concentration on specific locations in Los Angeles (Century City) and London (Canary Wharf). Supported and coached by Valery Alzaga, organizers

79 Van Klaveren and Sprenger, 'Union Organising in the Netherlands', 71. See also Goedhard and Tijdens, Beroepsbinding en vakbondsoriëntatie in de schoonmaak, http://handle.net/11245/1.351546. 8o Personal communication by Eddy Stam, 15 April 2016.

81 Kloosterboer, De vakbeweging van de toekomst; a revised version was published in English in 2007: Innovative Trade Union Strategies, http://www.scribd.com/doc/44286208/ Innovative-Trade-Union-Strategies.

82 Personal communication by Mari Martens, 5 February 2016.

83 McCallum, Global Unions, 64; Connolly, et al., "Justice for Janitors" Goes Dutch' (unpublished paper), 8-9.

84 Ibid., 9. See also the television documentary 'I Fight For You', first broadcast on 18 September 2006, http://www.npo.nl/tegenlicht-i-fight-for-you/21-07-2010/WO_VPRO_043771.

85 De Poetser. Ledenblad voor schoonmakers in Nederland (July 2006).

86 Interview with Ron Meyer, lead organizer FNV Bondgenoten, 24 August 2012, in Fontana, 'A Comparative Analysis', appendix, 106; see also https://www.fnv.nl/over-fnv/organisatie/ geschiedenis-van-de-fnv/geschiedenis-fnv-2005-heden/. 
contacted Schiphol cleaners, making appointments at cafes or at home, ${ }^{87}$ and in that same year FNV Bondgenoten was able to bring 33 people together who wanted to become involved. They were from such diverse locations as Turkey, Morocco, Ghana, Bangladesh, the Antilles, Suriname, the Dominican Republic, Italy, and the Netherlands ${ }^{88}$ Six of them were women, including Judy Lock, mentioned above: 'An FNV organizer approached me while I was drinking coffee and discussing work with a colleague after work', she later recalled. ${ }^{89}$ She became president of the Cleaners' Committee at Schiphol and a prominent spokeswoman for the cleaners during the 2010 strike. On 17 November 2007, a preliminary meeting of 500 cleaners was held in the Holiday Inn Hotel at Schiphol to launch a campaign for higher wages ( $€$ 10 an hour) under the slogan 'Voor een Betere Toekomst' ('For a Better Future').${ }^{90}$ Demonstrations at Schiphol and at offices of clients elsewhere in the Netherlands, and other symbolic actions, such as visits to the private mansions of directors of cleaning companies (a 'millionaires' tour'), put pressure on negotiations with employers..$^{91}$ In January 2008 , a new nationwide contract was signed, which included a pay rise from $€ 8.90$ to $€ 10$ an hour..$^{2}$ Unlike, for instance, in the United States, collective agreements in the Netherlands are negotiated nationally, and then made legally binding for the branch as a whole.

A conference of 65 activists at the beach resort of Renesse on 21 and 22 April 2008 decided to start a new campaign at Schiphol with the slogan 'Schiphol Schoon Genoeg' ('Schiphol Clean Enough'), demanding travel allowances for Schiphol cleaners, better facilities at the airport, and a fixed contract after nine months of work. The campaign started in November 2008 with a week of picketing and a march around the airport. Some 250 activists

87 For an account of the activities of FNV Bondgenoten organizer Herrie Hoogenboom at Schiphol, see De Fabel van de illegaal 84 (May/June 2007), http://www.doorbraak.eu/ gebladerte/11329f84.htm. For the involvement of Valery Alzaga, see the interview with Ron Meyer in Fontana, 'A Comparative Analysis', 108; https://www.globalinfo.nl/Nieuws/steundeschoonmakers, 12 October 2007; and Rob Lubbersen, 'Schoonmakers winnen!', Grenzeloos, 19 February 2008, http://www.grenzeloos.org/content/schoonmakers-winnen.

88 Eddy Stam, 'Kadergroep Schiphol', De Poetser. Ledenblad voor schoonmakers in Nederland (October 2007).

89 Emma Boelhouwer, 'Staking heeft schoonmakers ogen geopend', Het Parool, 14 April 2010. 90 De Fabelvan de illegaal, 89/9o (Winter 2008), http://www.doorbraak.eu/gebladerte/11384f89. htm; Koen Haegens, 'Het nieuwe werken op Schiphol. Opstand der schoonmakers', De Groene Amsterdammer, 16 November 2007.

91 Marijnissen, 'Met één hand kun je niet klappen', 6-7, 28-32.

92 FNV Bondgenoten, Mensen Voorop. Jaarverslag 2008 (Amsterdam, 2009) 6; Nico Lemmens,'Deregulering in de schoonmaak. Over de nieuwe schoonmaak-cao', Facility Management Informatie (May 2008), 54-57. 
were recruited, and, after several demonstrations and a four-day strike involving 500 cleaners (half of the workforce) at Schiphol, in the first week of April 2009 they won travel allowances, a $€_{150}$ bonus for the Schiphol cleaners, and a 0.5 per cent wage increase for all cleaners nationwide. ${ }^{93}$ There were smaller pickets by cleaners elsewhere in the country as well, but concentrating the campaign on Schiphol made it clear how much could be achieved by a relatively small number of dedicated activists. Union organizer Ron Meyer recalled in 2012: 'From 2008/2009 we started at Schiphol and in 2009 we had a strike for a couple of days with some 200 cleaners. And that was a real start of learning and getting an idea about how to plan and how to talk to people and how to organize. ${ }^{94}$

\section{The 2010 and 2012 national strikes}

To evaluate the Schiphol campaign and to prepare the negotiations for a renewal of the national collective agreement in 2010, another two-day conference was held on 25 and 26 May 2009, again in Renesse, with 50 representatives from various parts of the country. The conference decided to rename itself the 'Cleaners' Parliament', and to demand additional travel allowances, no more unpaid sick leave in the event of illness, Dutch lessons for immigrants in working time, and a 3 per cent wage rise. ${ }^{95}$ For the cleaners at the conference, the most important issue was respect for the cleaner and for cleaning as a profession. This was lost, in their opinion, because clients and cleaning companies were competing only on price. Wages were under pressure, and cleaners were forced to work harder and harder at the expense of the quality of their work. ${ }^{96}$

At a meeting of this 'parliament', now enlarged to comprise 75 members, held on 12 December 2009 at Amsterdam's Town Hall, a White Paper on the cleaning industry in the Netherlands was presented to substantiate this

93 See http://www.facility.vakwereld.nl/Nieuws/1/2365: 'FNV Bondgenoten voor rechter gesleept'; 1/2394: 'Schoonmakers op Schiphol staken'; 1/2421: 'Schoonmakers Schiphol blijven in staking'; FNV Bondgenoten, Mensen Voorop. Jaarverslag 2008, 33; De Poetser. Ledenblad voor schoonmakers in Nederland (March 2009): 'Beeldverslag van de acties Schiphol'; 'Schiphol, de feiten'; ibid. (September 2009): 'Schoonmakers voeren actie voor een goede cao. Een fotoreportage'; Rob Rombouts, 'Schoonmakers aan de slag na akkoord', Het Parool, 8 April 2009.

94 Interview with Ron Meyer, in Fontana, 'A Comparative Analysis', appendix, 107; http://www. facility.vakwereld.nl/Nieuws/1/2394: 'Schoonmakers op Schiphol staken', mentions 50o strikers.

95 De Poetser. Ledenblad voor schoonmakers in Nederland (September 2009), 7-8.

96 Ibid. (May 2010), 7. For the cleaners demanding 'respect', see the interview with Ron Meyer in Fontana, 'A Comparative Analysis', appendix, 112. 
argument. ${ }^{97}$ The sector was in crisis, the report argued. While cleaning as an industry was growing fast, contracting out and the competition between cleaning companies was causing uncertainty, instability, and downward pressure on prices in a race to the bottom. Consequently, wages, working conditions, and cleaning standards were being undermined. It was in the interests of the sector as a whole - clients, cleaning companies, and cleaners - to put an end to this crisis by regulating standards of work and working conditions. Clients especially are vulnerable to being confronted with lowquality work, because 'the cleaning companies have degraded themselves to become clubs of cheap labour, and they are prepared to sink even lower. ${ }^{9}{ }^{8}$

In negotiations with the representatives of the cleaners' union, the cleaning companies showed no inclination whatsoever to concede to any of the demands formulated by the union. ${ }^{99}$ The 'Cleaners' Parliament' therefore decided to call a strike in 2010. After a month of short warning strikes, pickets, meetings, and demonstrations at different locations, the strike was officially called on 16 February. The total number of strikers was around $1,400,{ }^{100}$ surprisingly low compared with the 15,000 union members in the cleaning sector. However, because of the high participation of train cleaners (40o strikers), its consequences were notable at railway stations and in trains, and the relatively small number of strikers was compensated for by almost daily actions and protests, clearly copied from the us Justice for Janitors 'militant minority' repertoire (see Appendix 7.1). These actions were consciously designed to put pressure on clients of the cleaning companies by getting as much media attention and public support as possible - by showing colourful banners, handing over symbolic presents, sewing 'the largest duster in the world', banging drums, having all demonstrators wear orange FNV jackets, and the like. The campaign found a strong resonance with the Dutch population: signatures and testimonials were widely collected, and public figures and celebrities pledged their support. On 21 April, the international union UNI Global Union announced the start of a solidarity campaign of picketing at Dutch embassies, ${ }^{101}$ but this proved unnecessary as an agreement was reached on 22 April.

97 De Poetser. Ledenblad voor schoonmakers in Nederland (January 2010), 5-7.

98 Schoon genoeg. Op naar een betere toekomst voor de schoonmaaksector! (Amsterdam, 2009), 14.

99 Elsbeth Stoker, 'Gesprekken over cao schoonmaak vastgelopen', De Volkskrant, 9 December 2009.

100 Heuts, Tegenmacht, 12; elsewhere the number of strikers is estimated to have been even lower: Heuts, "'No More Being Ground Down for Us"' $(1,000)$; 'Schoonmakers hervatten werk na cao-akkoord', NRC Handelsblad, 22 February $2010(1,100)$.

101 Elsbeth Stoker, 'Internationale steun schoonmakers', De Volkskrant, 21 April 2010. 
Figure 7.3 Meeting of the 'Cleaners' Parliament' in the Amsterdam Town Hall, 12 December 2009

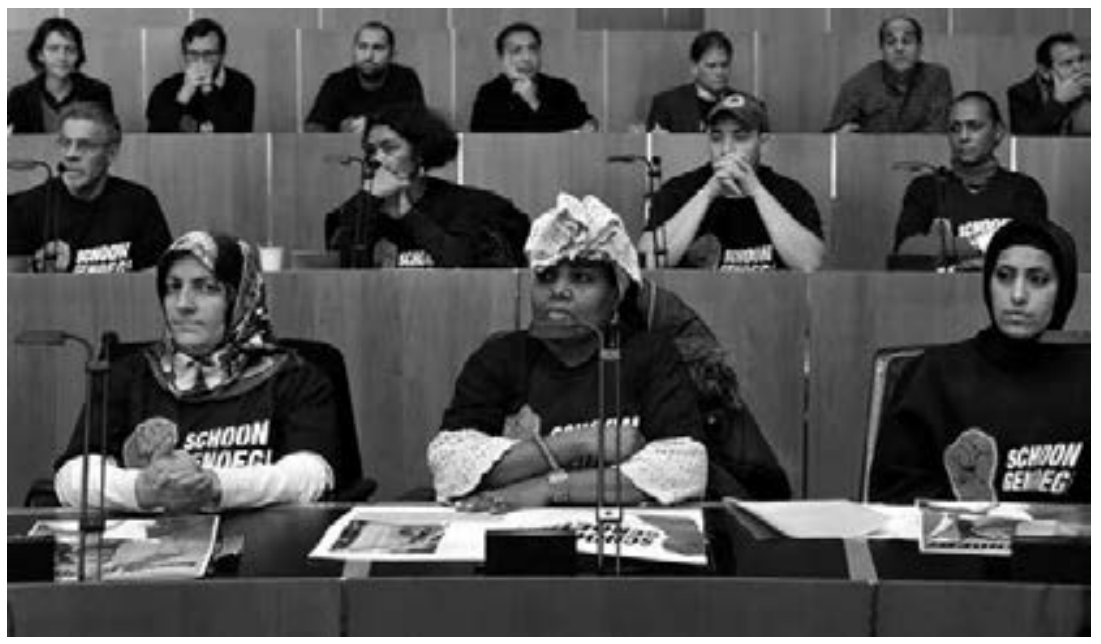

Photograph by Rob Nelisse. Used with permission

As was intended, the perseverance of the strikers put pressure on the clients of the cleaning companies, foremost Schiphol and the Ns (Nederlandse Spoorwegen) railway company. They demanded arbitration to put an end to the strike. In the press, representatives of the cleaning companies now endorsed the analysis of the union's White Paper that the sector was 'in crisis', admitting that the market had been ruined by competition and a race to the bottom. ${ }^{102}$ On 22 April an agreement was reached on a 3.5 per cent pay rise over the next two years, a bonus of 18 per cent for the strikers, and opportunities to learn Dutch in working time. Both clients and contractors agreed to cooperate in a covenant for good employment practices, or 'code for responsible market behaviour in the cleaning industry'. ${ }^{103}$

Employers' representatives now welcomed the new agreement because 'without a contract, cleaning companies would compete even more on lower

102 Jurry Brand and Jarco de Swart, 'Opdrachtgevers pakken rol op in schoonmaakconflict', $D e$ Telegraaf, 5 March 2010; Elsbeth Stoker, 'Schoonmakers pikken het niet langer', De Volkskrant, 5 March 2010; idem, 'Wie betaalt inburgering schoonmakers?', De Volkskrant, 18 March 2010; 'Topman Schiphol springt op de bres voor schoonmakers', Trouw, 9 April 2010.

103 'Schoonmakers hervatten werk na cao-akkoord'; 'Positie van schoonmakers verbetert', NRC Handelsblad, 22 April 2010. The code was signed on 21 June 2011: De Poetser. Ledenbladvoor schoonmakers in Nederland (October 2011), 5. See also http://www.codeverantwoordelijkmarktgedrag.nl/home/. 
prices and wages. That would be to the detriment not only of the cleaners, but also of the small and medium-sized cleaning companies. ${ }^{104}$ Representatives of the large cleaning companies csu and Hago admitted that the strike had opened their eyes to the detrimental effects of competition. ${ }^{105}$ The former human resources manager at NS, now chair of the committee to supervise the above 'code', even stated: 'in hindsight, some employers recognize that the strike revealed the stranglehold they were in'. As the Dutch law on free competition forbade the regulation of markets by minimum tariffs, a voluntary code on market behaviour was deemed necessary to prevent a downward spiral in tendering. ${ }^{106}$ Clearly, for these employers, the collective agreement and the 'code of conduct', enforced by the strike action of the cleaners, were instruments to regulate the market. It is a sign that 'regulatory unionism', as practised in Los Angeles, London, and Australia, was an important element in the cleaners' struggle in the Netherlands as well.

'Regulatory unionism' can be effective, however, only if a union is able to exert enough power in the labour market. On 24 and 25 October 2011, a newly elected 'Cleaners' Parliament' assembled at the trade union centre Burcht van Berlage, the former headquarters (built in 190o) of the iconic Dutch diamond workers' union in Amsterdam. Pictures of this meeting reveal the colourful and multi-cultural character of its membership and the prominent role of women among the activists. The 'parliament' chose a twelve-member strong 'cabinet' and the Amsterdam hospital cleaner Khadija Tahiri as its president. The 'parliament' discussed demands for the renewal of the collective agreement in 2012: a lower workload, a wage rise of $€ 0.50$ an hour, an annual bonus of $€_{300}$, and - a demand remaining from the previous round of negotiations - no waiting days for sick pay in the event of illness. The voluntary 'code of conduct' was deemed to be merely a fig leaf, because it was used only as an instrument to regulate the tendering of the cleaning companies, not to protect cleaners. Competition on prices was replaced by competition on working conditions and increasing workloads. ${ }^{107}$ This argument was supported in a new White Paper, discussed at another

104 Cited by Sander Heijne and Elsbeth Stoker, 'Cemal wil niet twee jaar wachten op die 3,5 procent', De Volkskrant, 23 April 2010.

105 Heuts, Tegenmacht, 16, 89; they repeated this opinion in the television programme Zembla, 'Schoonmaakwoede', 23 May 2010.

106 Heuts, Tegenmacht, 111-112.

107 Henk Cornelisse, 'FNV Bondgenoten als huwelijkskandidaat', Clean Totaal, 4 November 2011; Marike Stellinga, 'Schoonmaakparlement "geeft nooit toe"', NRC Handelsblad, 25 November 2011. An overview in 2013 showed that only nine out of nineteen big clients had signed the 'code': $F N V$ Schoonmaak, Gewoon schoon! De schoonmaaksector anno 2013 (Amsterdam, 2013). 
meeting of the 'Cleaners' Parliament' in Rotterdam on 15 December 2011. ${ }^{108}$ FNV Bondgenoten proposed to introduce stricter regulation of the market, in what it called a 'Gold Standard', but it could not convince the cleaning companies. ${ }^{109}$ Instead, they reproached the union for not complying with the 'code', which apparently for them was primarily an instrument to pacify industrial relations. ${ }^{110}$

Negotiations on the unions' demands were broken off by the cleaning employers on 8 December 2011. On 2 January 2012, the next strike was called. The tactics and repertoires were very much like those in 2010, but on a larger scale. There were now 3,00o strikers in total, and the strike targeted more locations. Throughout January and February there were ten large 'marches for respect' in different localities around the country, each with several thousand participants. Countless events, pickets, and meetings were held; public support was mobilized; some 6,00o emails offering support were received from all over the world. ${ }^{111}$

In April, a few individual cleaning companies and three of the hardest-hit clients, railway company Ns, Schiphol Airport, and the Rotterdam Erasmus Medical Centre, urged the employers to reach a compromise with the union. On 16 April, after a strike lasting 105 days, the cleaning companies finally realized that regulating the market would be possible only at a higher level of wages and with improved working conditions. Parties agreed on a pay rise of 4.85 per cent over two years, better training facilities, and more fixed contracts for agency workers. On payment during the first few days of illness, a compromisewas reached, with the parties agreeing to investigate this issue further. The cleaners had to wait for the next round of negotiations and a twelve-week strike in 2014 to finally achieve this goal; it was secured despite, again, the relatively low number of strikers $(1,400) .{ }^{112}$ In the meantime, they continued their meetings and discussions in the 'Cleaners' Parliament' and remained confident about the power of organizing.

It is not yet clear what the future of the Dutch cleaners' union will be, but to others in and outside the union they set an example of how to combat

108 FNV Bondgenoten/Vakbond van schoonmakers, Let's get real. Schoon genoeg van de schijnwereld in de schoonmaaksector (Amsterdam, 2011).

109 Ibid.; Henk Cornelisse, 'FNV Gouden Standaard. Alles goud wat er blinkt?', Clean Totaal, 9 December 2011.

110 Henk Cornelisse, 'FNV Bondgenoten. Schoonmaakstaking als reddingsboei?', Clean Totaal, 4 January 2012.

111 For an overview, see http://www.schoongenoeg.nu, and the leaflet in Schoon genoeg! Respect voor schoonmakers, 1 (May 2012).

112 For an overview, see Schoon genoeg! Respect voor schoonmakers, 6 (July 2014). 
Figure 7.4 March by some 400 cleaners during a sit-in at Utrecht Central Station, 16 March 2010

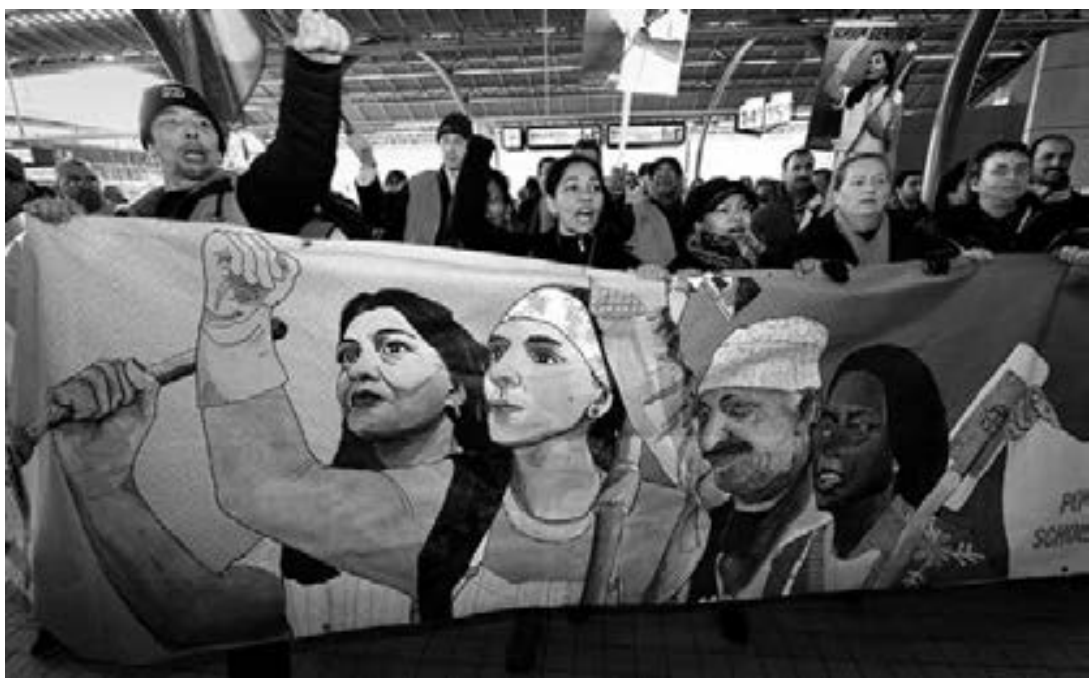

Photograph by Rob Nelisse. Used with permission

the detrimental effects of neoliberal restructuring and the precariatization of work. One of the more spectacular actions during the 2012 strike was the occupation of the vU University Amsterdam on 5 March by 1,000 cleaners. ${ }^{113}$ The occupation coincided with protests by students and staff against university reforms and cuts, and the university committee called on them to show solidarity with the cleaners. According to the then student leader and Ph.D. student Matthias van Rossum, it was a turning point in the university campaign:

\begin{abstract}
Although the kind of work differs a lot, the problems of university staff and cleaners are in fact very much alike: flexibilization, undermining of work standards and diminishing influence on labour relations, lack of appreciation, hardening of management styles. The occupation by the cleaners made a huge impression on the university staff. They became aware that if the cleaners can organize, they should be able to do so too. ${ }^{114}$
\end{abstract}

113 'Schoonmakers, VU-personeel en studenten. De kracht van gezamenlijke strijd', 3 April 2012, http://socialisme.nu/blog/nieuws/25406/schoonmakers-\%e2\%8o\%98het-besef-hoekrachtiggezamenlijke-strijd-kan-zijn\%e2\%80\%99/\#sthash.poHpueqD.dpuf.

114 Matthias van Rossum, 'Werken van onderop, maar ook van bovenaf de vakbond veranderen', Grenzeloos, 19 May 2015, https:/www.grenzeloos.org/content/werken-van-onderopmaar-ook- 


\section{Conclusion: regaining character}

In his well-known book The Corrosion of Character, on the psychological effects of the fragmentation and flexibilization of labour markets in modern capitalism, Richard Sennett refers to a janitor he interviewed for his earlier work The Hidden Injuries of Class (1972):

Enrico had spent twenty years by the time we first met cleaning toilets and mopping floors in a downtown office building. [...] His work [...] seldom varied from day to day. And along that time, achievement was cumulative: Enrico and [his wife] Flavia checked the increase of their savings day by day $[. .$.$] the time they lived was predictable [. .$.$] unions$ protected their jobs; though he was only forty when I first met him, Enrico knew precisely when he would retire and how much money he would have. ${ }^{115}$

Today, such a well-organized and future-oriented life plan for cleaners is difficult to imagine. ${ }^{116}$ Since Sennett wrote that book in 1972, employers have increasingly distanced themselves from workers through the use of subcontracting, labour market intermediaries and agencies, and selfemployed contractors. This restructuring caused a break with the post-war 'standard employment relation' for male workers like Enrico. The negative impact on wages and welfare provisions is particularly visible in the cleaning business. Cleaners all over the world increasingly work for companies that compete for often short-term contracts with clients. As they are no longer employed by the client firm, employers are able to shed responsibility for the maintenance of labour standards, social security, and other rights.

The outsourcing of cleaning allowed for the recruitment of people outside regulated labour markets. Everywhere, immigrants are overrepresented in the cleaning workforce, which in addition comprises many women with part-time, irregular jobs. Especially in large 'global cities', labour markets are polarized, with mobile workers in both the top and the bottom segments. ${ }^{117}$ Low-paid workers, in building maintenance for example, are indispensable if

van-bovenaf-de-vakbond-veranderen. Van Rossum is now a research fellow at the International Institute of Social History in Amsterdam.

115 Sennett, The Corrosion of Character, 15-16.

116 Pension rights of flex workers, such as cleaners, are often fragmented because of short-term and part-time contracts, and low wages: 'Flexwerkers moeten later een écht pensioen krijgen', NRC Handelsblad, 16 April 2016.

117 Sassen, The Global City. 
the city (and its top layers) are to work. Most of the workers at the lower end are immigrants. They, more than anyone else, experience the psychological effects of the flexibilization of labour markets, described by Sennett as 'the corrosion of character':

The system [...] radiates indifference [...] through reengineering of institutions in which people are treated as disposable. Such practices obviously and brutally diminish the sense of mattering as a person, of being necessary to others. [...] Under these conditions, character corrodes: the question 'Who needs me?' has no immediate answer. ${ }^{118}$

In such a fragmented and highly individualized labour market, social cohesion and common ground to organize collectively are hard to find. The prospect of unionizing by precarious, immigrant workers is not immediately self-evident; efforts to do so have often led to disappointing results. Unions considered workers such as cleaners hard to organize, also because they work out of sight, alone, or in small groups, so that organizing at the workplace did not really seem feasible.

This changed when unions such as the SEIU in the United States and FNV Bondgenoten in the Netherlands put financial and personal resources into organizing campaigns and sent in specially trained organizers. By offering opportunities for cleaners to become active themselves, by identifying and training rank-and-file leaders, and by inventing a whole range of new repertoires of direct action, they were able to turn the social and psychological disadvantages of isolation, invisibility, and precariousness into a moral advantage. The cleaners' campaigns principally aimed to make the invisible and largely immigrant workforce highly visible in the public sphere by undertaking strikes, demonstrations, and 'shaming rituals' in or near the glittering skyscrapers in the financial districts, transport hubs, and other crucial sites of the wealthy, such as the mansions of manager-millionaires. Smaller and larger manifestations, demonstrations, occupations, picket lines, festive parties, and gatherings, with colourful banners and vests, gestures, songs, and shouted slogans, all had the effect of empowering and enthusing the participants collectively. ${ }^{119}$ Framed as a morally compelling cry for social justice, respect, and recognition, the cleaners' campaigns

118 Sennett, The Corrosion of Character, 146-147.

119 For a comprehensive analysis of the empowering effects of the action repertoires, see Paauwe, 'Tegenkracht', http://dare.uva.nl/cgi/arno/show.cgi?fid=459794. 
won the sympathies of the public as well as of key figures in the political and media arenas.

Some labour movement activists and writers in the United States have criticized the SEIU's Justice for Janitors campaigns as too top-down, rather than being initiated and sustained from below by the rank and file. In some instances, these critics say, the SEIU has practised old-style union authoritarianism, thereby failing to really involve and empower workers. ${ }^{120}$ However, confidence in a 'rank-and-file strategy' without institutional backing by established unions is hard to gain in a situation of fragmentation and isolation of precarious workers, such as cleaners. Once offered opportunities to organize and fight back by the top-down efforts of union organizers, a core of conscious cleaners, especially women, were able to regain their 'sense of mattering as a person' and their dignity as workers, to develop leadership, and to put energy into campaigning for their rights collectively. This energy would not have been mobilized without organizing top-down by the established unions, while top-down organizing would have been useless without mobilizing this energy from below.

While based on inventive new repertoires of public action to overcome the degradation, isolation, and invisibility of the mostly immigrant and female workforce in outsourced cleaning, the strategies of the cleaners' unions in the United States, London, Australia/New Zealand, and the Netherlands were all geared towards what can be defined as the core business of trade unionism: regulating labour markets by agreeing with employers and clients to 'take wages out of competition'. As Ruth Milkman emphasized in her study on the Los Angeles case, there is a long history of this type of regulatory unionism, both in the United States and in Europe. ${ }^{121}$ From this perspective, the organizing campaigns invented by Justice for Janitors were innovative in form, ${ }^{122}$ but quite traditional in content. The regulatory unionism as practised in the campaigns presupposed a spatial labour market that could be territorially defined and regulated. In the United States and Great Britain, where contracts had to be negotiated locally firm by firm, the campaigns had a 'zonal' approach and were aimed at unionizing cleaning

120 The most pertinent of these critics, not so much of the Justice for Janitors campaign itself as of the SEIU's internal organization, is Moody, US Labor in Trouble and Transition. See also McCallum, Global Unions, 67-69.

121 Nineteenth- and early twentieth-century examples can be found in Chapter 4 of this book. 122 I do not engage here in the debate as to whether the Justice for Janitors repertoire was an original 'invention' or a 'revival' of older union tactics. As stressed by Charles Tilly, most contemporary forms of contention adapt, permute, and innovate repertoires inherited from the past. 
firms locally and zone by zone. In the Netherlands, this was tried with some success at Schiphol Airport, where, in 2008, separate benefits were obtained for the cleaners working there, but, as a consequence of the Dutch system of industrial relations, the Dutch campaigns could gain strength only by organizing nationwide to enforce national collective agreements.

From this regulatory perspective, the endeavours of the SEIU to focus transnational campaigns on multi-national cleaning companies such as Iss and to negotiate transnational or 'global' contracts were somewhat paradoxical, as union power to enforce labour market regulation still had to be developed locally or, as in the Dutch case, nationally. The maxim of the SEIU's Stephen Lerner that 'the building owners are global, the investment capital is global, the contractors are global, and the workers are global' may be true, ${ }^{123}$ but not enough to warrant a globally organized labour market. For me, it remains completely unclear how, as Lerner asserts, 'through global agreements episodic campaigning may move toward a much-needed institutionalized power capable of challenging global capitalism systematically'.24 The migrant labour force may be as transnational as the multi-national cleaning companies, the labour markets on which both parties operate are still institutionalized locally or nationally. The transnationalism of the SEIU and its international partners in UNI Global Union concerns officials and organizers, not the cleaners themselves. It can connect the local and the global only by supporting efforts to build union capacity at a local or national level, while simultaneously organizing global support for cleaners campaigning for their rights. In spite of the general framework provided by the Socially Responsible Contractor Global Agreement signed by UNI Global Union and Iss, the global appeal of Justice for Janitors was, and still is, based on international solidarity, not on transnational labour market regulation.

A symbol of this kind of international solidarity was presented by UNI Global Union when it awarded the Dutch 'Schoon Genoeg!' campaign of 2010 the prize for the world's best trade union campaign in the previous five years. Cleaners' representatives Judy Lock and Christine Monk, together with FNV Bondgenoten official Mari Martens, went to Tokyo to receive the honour. For Christine Monk, the international prize 'meant a great deal of support not only for us cleaners, but also for our colleagues in, for instance, security, catering, home care, and nursing. Its message is: you can win if you want to!'125

123 Lerner, 'Global Unions', 29.

124 Cited in Moberg, 'Translating Solidarity', A12.

125 Cited in 'Hollandse schoonmakers zijn wel wereldkampioen', De Telegraaf, 9 November 2010. 


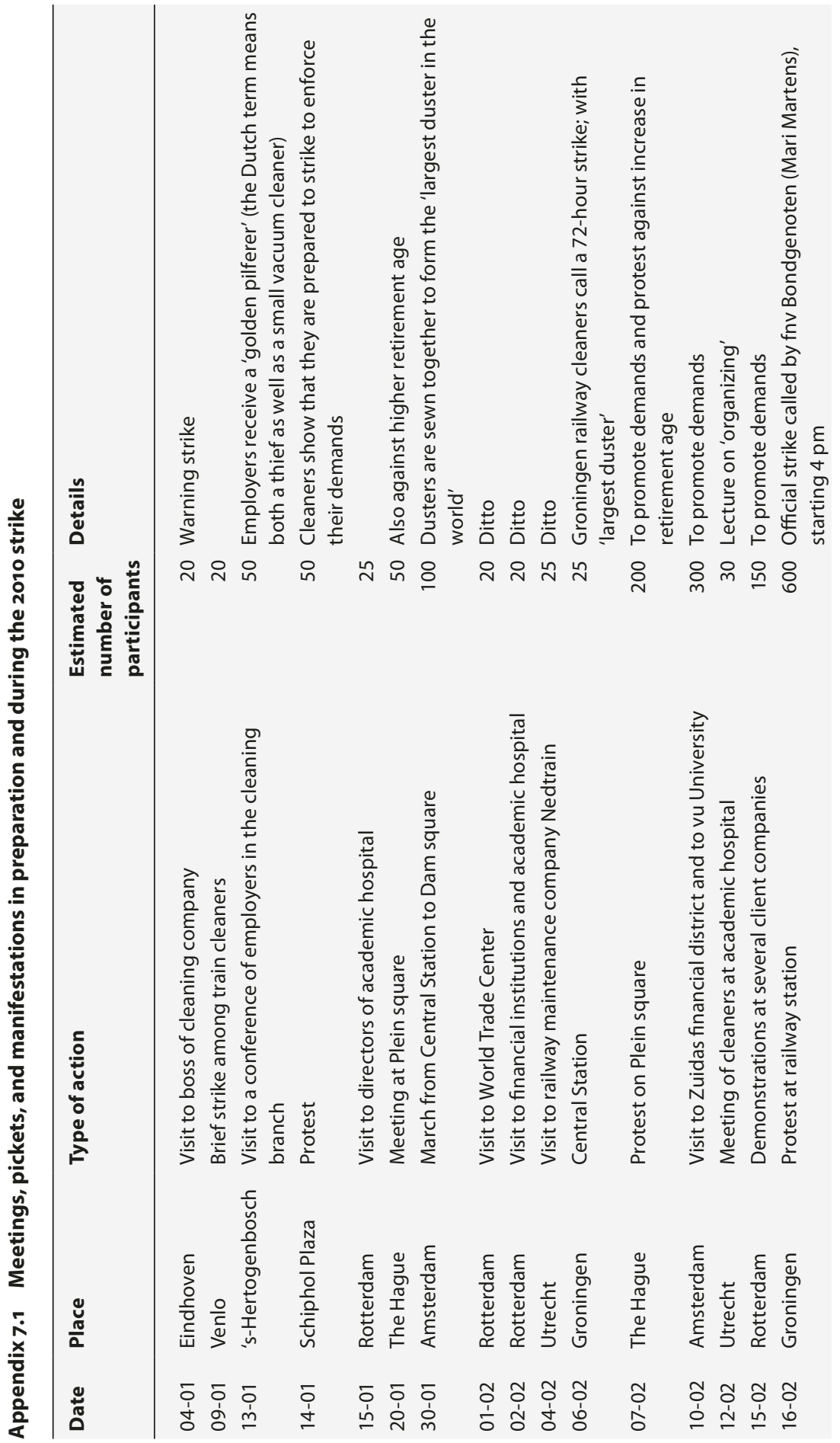




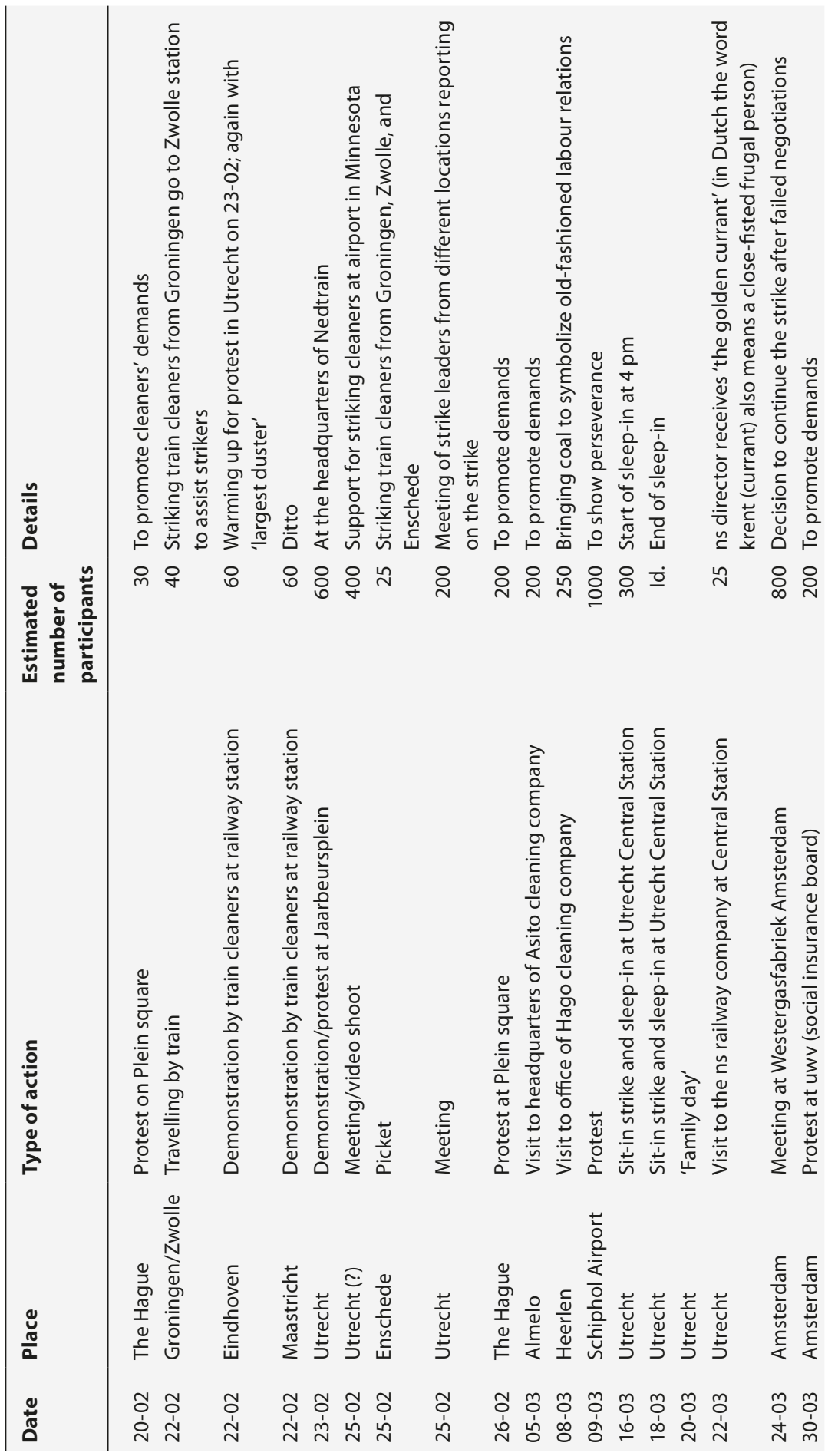




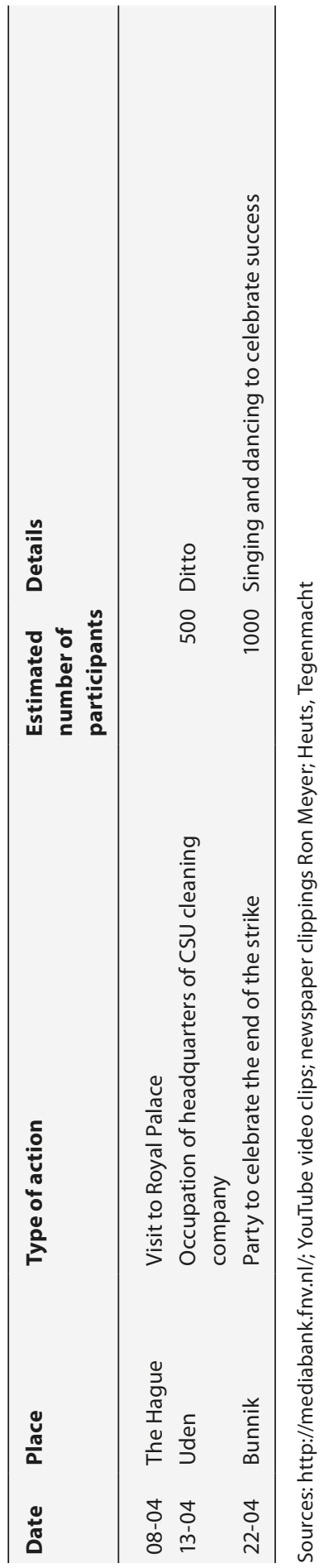




\title{
Conclusion: Past and future transformations
}

\begin{abstract}
In the conclusion the central arguments of the case studies are brought together. The detailed analyses of specific industries and unions in this book provide deeper insight into how varieties of unionism emerged and transformed under the impact of changing labour regimes. Its transnational perspective privileged the analysis of nineteenth- and early twentieth-century developments, as in the twentieth century labour organizations reoriented towards the nation-state at the cost of transnational connections. Two developments stand out: firstly, the involvement of trade unions in social policies by what was later to become the welfare state, and, secondly, the rise of mass industrial unionism able to force concessions from the employers and the state. After the Second World War this resulted in the so-called Fordist class compromise, which to a great extent determined the structure and behaviour of trade unions in Europe and the United States until roughly the 1970s. The long-term perspective taken in this book enables us to recognize twentieth-century mass industrial unionism, organized on a national basis, as a separate episode in trade union history, at least in its classical North Atlantic heartlands. How future transformations of trade unionism will look is hard to predict, but it is to be expected that, because of the internationalization of capital and the globalization of production and labour, the trade union movement will become more global and adopt a transnational agenda again.
\end{abstract}

Keywords: varieties of trade unionism, mass industrial unionism, industrial relations, Fordism, wage rates, crisis of trade unionism, trade union renewal

Knotter, Ad, Transformations of Trade Unionism: Comparative and Transnational Perspectives on Workers Organizing in Europe and the United States, Eighteenth to Twenty-First Centuries. Amsterdam, Amsterdam University Press, 2018 DOI: 10.5117/9789463724715_CONCL 
In all cases studied in this volume, some form of 'continuous association' (to use the Webbs' crucial phrase) emerged to defend or expand workers' rights which had tended to be undermined by employers' strategies to create or exploit unfavourable labour markets. In the eighteenth century, cloth shearers in the Verviers and Aachen borderlands formed associations and organized industrial action to end the arbitrariness in setting wages and conditions of labour by employers who had deliberately moved industries to the unregulated countryside to be able to act as they pleased in the labour market. Cigar-makers connected internationally in the early $1870 \mathrm{~s}$ to prevent the importation of strike breakers by employers from abroad and to counter the downward levelling effects of transnational labour markets. Amsterdam carpenters started to concentrate on wage issues from the late 188 os after their labour market had been deregulated by speculative builders and after there had been an influx of immigrants in the building trades. Craft workers in Belgian and Us window-glass manufacturing organized in the 188 os against attempts by employers to break their monopoly of skill by allowing more apprentices and importing immigrants from abroad. In the 189os, the Amsterdam diamond workers' union opposed their wages being squeezed because of the unfettered competition between small employers. Until the beginning of the twentieth century, all over Europe trade unions organized labour intermediation themselves to control supply and prevent workers from being employed below standard wage rates. And, last but not least, the case of late twentieth- and early twenty-first-century 'Justice for Janitors' shows that trade union action was the only means to counteract the fierce wage competition between employers in the outsourced cleaning industry.

Workers formed 'continuous associations' in these cases, because developments in the labour market and employers strategies made collective action necessary to regulate market conditions in their favour. With John Stuart Mill (as quoted in the Introduction) we may conclude that workers' associations were 'the indispensable means of enabling the sellers of labour to take due care of their own interests under a system of competition'. However, forming 'continuous associations' does not necessarily imply a 'continuous evolution' of varieties of trade unionism from one form to another. From my case studies I conclude that the evolution of trade unionism was discontinuous, and that in different situations new forms of unionism emerged. Either there was no evolution of one variety to another at all, or there was discontinuity in content under the guise of an apparently continuous form. In some cases, trade unionism had to be invented anew (in new industries), while in others it was transformed by new generations or categories of workers in the same 
industry (as in the Amsterdam building trades and in Belgian window-glass making). This is consistent with Mill's opinion (shared by many others, including Marx and the Webbs) of a 'necessary instrumentability' of unions in a market for wage labour: even if there is no transfer of knowledge or tradition how to organize, it is to be expected that workers will try to find ways to regulate that market in one way or another, and will form 'continuous associations' to do so.

There is no need to restate here that the notion of different models of trade unionism has been a key insight in labour history. New challenges in the structure of production and labour markets could be solved only through new forms of labour organization (as for example the shift from craft to industrial unionism or the emergence of the 'New Unionism' in Britain from 1889), and new repertoires of industrial action (such as sit-down strikes or factory occupations in the period of mass industrial unionism). The detailed analyses on the level of specific industries and unions in this book have provided deeper and more concrete insights into how different varieties of unionism emerged and transformed under the impact of changing labour regimes. One example is the case of 'manufactural unionism', a term I invented myself to differentiate this specific variety of pre-industrial organizing before the factory from 'artisanal associationalism', also emerging before the factory, but in completely different circumstances and industries. 'Artisanal' solutions, i.e. producers' cooperatives, were not only propagated by artisans in the early Amsterdam labour movement, but also adopted by craft unions in American window-glass making to avoid deskilling and levelling with less-skilled workers in mechanized factories. The transformation from artisanal associations to trade unions as wage-bargaining agents 'pure and simple', as analysed in the case of Amsterdam, was of a different kind, however, than the evolution from exclusionary craft unionism to general industrial unionism in window-glass and diamond factories.

These were mainly nineteenth-century developments. In the twentieth century an interconnected transformative complex developed consisting of the involvement of trade unions in social policies and insurances organized by the state (predating or becoming part of the welfare state), the nationalization of labour movements (partly as a consequence of this development), and the rise of mass industrial unionism as a force able to extract concessions from the employers and the state (for instance in the Us New Deal in the 1930s). The result was the so-called Fordist class compromise after the Second World War, which combined partial recognition of welfare and wage claims by the labour movement with economic growth. Although I did not include comparative studies on mass industrial unions in this 
period, the incorporation of European trade unions into state-led institutions of labour intermediation in the early twentieth century as described in Chapter 5 can be considered a first sign of the closer alliance of trade unions and the state. The post-First World War development of the Dutch Christian Miners' Union was presented as an example of the nationalization of labour unions in general.

The analysis of specific varieties of trade unionism in the nineteenth century, often attempting to organize internationally to better control transnational labour markets of artisans and craft workers, enables us to recognize twentieth-century mass industrial unionism, organized on a national basis, as a new episode in trade union history. From this perspective, the apogee of trade unionism in the 196os/1970s, referred to in the Introduction, should be rather considered the high tide of this specific form of unionism. The idea that trade unionism has been in decline for some decades now, since the formidable upsurge of class conflict in this period, is shared by many observers, both inside and outside the labour movement. A host of studies, often based on national comparisons, conclude that there is a crisis of trade unionism, especially in its original heartlands in Europe and the United States (and also in former British settler colonies such as Australia). ${ }^{1}$ The crisis has been analysed as a part of the crisis of the post-war 'Fordist class compromise' in general. The increased global mobility of capital, relocation and deregulation of manufacturing industries, de-industrialization, and the restructuring of the labour force as a consequence of rapid technological change undermined union power and the potential for union growth precisely in those economic sectors where once powerful mass industrial unionism had found its strength. In spite of national varieties of the 'roads to post-Fordism, ${ }^{2}$ this trend was observable in all countries in Europe and North America. In hindsight, and bearing past transformations in mind, mass industrial unionism and its concomitant national orientation can now be analysed as a specific twentieth-century variety in the history of trade unionism, at least in its classical North Atlantic heartlands.

However, a general decline of mass industrial unionism has been questioned by Beverly Silver in her much-cited analysis of the global development of the 'forces of labour' in the twentieth century. Taking global shifts in

1 For instance Gumbrell-McCormick and Hyman, Trade Unions in Western Europe; specifically on the British case: Fernie and Metcalf (eds), Trade Unions. The theme of decline is also addressed in volumes on the future of unionism: Regini (ed.), The Future of Labour Movements; Phelan (ed.) The Future of Organised Labour.

2 Koch, Roads to Post-Fordism. 
the automobile industry as an example, she showed that mass industrial unionism and action followed the movement of capital from the United States in the 1930s to Europe in the 196os, and to Brazil, South Africa, and South Korea in the $1980{ }^{3}{ }^{3}$ Her account shows firstly how enlightening a transnational sectoral approach (like the one chosen in this volume) can be in contrast to national comparisons, and secondly that concepts such as 'Fordism' and 'post-Fordism' are profoundly Eurocentric (including North America) and do not apply to economic developments in the 'global South' (including China), where manufacturing industry has expanded in parallel to its demise in the advanced capitalist countries in the 'global North'. It remains to be seen, however, to what extent mass industrial unionism will develop in recently industrialized countries in Asia and Latin America.

Nevertheless, we may safely conclude that in Europe and the United States mass industrial unionism as the driving force of unionism in general has become a phenomenon of the past. How future transformations of trade unionism will look, and if there will be a 'next upsurge' as Dan Clawson claimed some years ago for the United States, ${ }^{4}$ is hard to predict. Trade union 'renewal' or 'revitalization' is a major topic of trade union research, ${ }^{5}$ but there is no conclusive argument as to what direction this might take. There can be no doubt, however, that success in organizing will determine future wages and conditions. There is no fundamental difference between today's casualized and precarious workers in the global North and in the global South. Many of them face conditions similar to those of workers in nineteenth-century Europe and the United States. ${ }^{6}$ The difference lies in the historical experience of organization and consciousness: whether people can see themselves as part of a collective with the power of changing working conditions and - for that matter - society.

Some of the transformational dimensions of future organizing can perhaps be found in the transnational Justice for Janitors campaigns, as described in Chapter 7 of this book, for various reasons. First of all, the campaigns were fought in the service sector. The growth of this sector in so-called post-industrial societies led to an enormous expansion of a low-paid and insecure workforce in branches such as retail, catering, care, transport,

3 Silver, Forces of Labor.

4 Clawson, The Next Upsurge.

5 For an overview on unions in the European Union: Bernaciak, Gumbell-McCormick and Hyman, European Trade Unionism; in a global perspective: Phelan (ed), Trade Union Revitalisation, and Schmalz and Dörre (eds), Comeback der Gewerkschaften?

6 For a comprehensive overview of the history of and debate around precarious work, see Betti, 'Historicizing Precarious Work'. 
delivery services, and the like. Justice for Janitors showed that it was possible to 'organize the unorganized' in these kinds of service industries. Secondly, a key strategy in the Justice for Janitors campaigns was to expand membership involvement and to stimulate organizing from below, in contrast to the often top-down bureaucratic structures characteristic of mass industrial unions. Thirdly, Justice for Janitors managed to activate female workers as union activists, an important prospect for trade unionism in the low-paid service sector where women are employed in ever greater numbers. Fourthly, immigrant workers were at the forefront of the campaigns everywhere, as a kind of internationalism within national borders. Considering the growth of the immigrant workforce in all capitalist countries as a result of the internationalization of labour markets in today's global economy, this is a very important prospect. Several authors in the United States have hailed the increasing involvement of immigrants in the us trade union movement as an important sign of renewal. 7

Last but not least, the attempts to transnationalize Justice for Janitors by the SEIU, however limited by the strength of national and local labour market institutions, signal a reorientation in the trade union movement as a whole. Transnational trade unionism is becoming increasingly important, and it has to be, because of the internationalization of capital, the growing importance of multi-national companies, the global interconnectedness of production sites and commodity chains, increasing international labour mobility, and global wage competition. New possibilities for international network-building, cooperation, and mobilization have emerged. These developments have involved unions in very different economic spheres and sectors. ${ }^{8}$ It is too early to speak of a new era of transnational unionism, but there are signs that new transformations of trade unionism are under way to adapt to new conditions of work and employment in today's globalized economy. 


\section{Bibliography}

Ackers, Peter, and Adrian Wilkinson (eds), Understanding Work and Employment: Industrial Relations in Transition. Oxford, 2003.

Adell-Gombert, N., Des hommes de devoir. Les compagnons du Tour de France (XVIIIe-XXe siècle) [Ethnologie de France 30]. Paris, 2008.

Aguiar, Luis L.M., 'Restructuring and Employment Insecurities: The Case of Building Cleaners', Canadian Journal of Urban Research 9(1) (2000), 64-93.

Aguiar, Luis L.M., and Andrew Herod (eds), The Dirty Work of Neoliberalism: Cleaners in the Global Economy. Oxford, 2006 [also in Antipode: A Radical Journal of Geography 38(3) (2006), 425-666].

Aguiar, Louis L.M., and Shaun Ryan, 'The Geographies of the Justice for Janitors', Geoforum 4o(6) (2009), 949-958.

Albright, Jason, 'Contending Rationality, Leadership, and Collective Struggle: The 2006 Justice for Janitors Campaign at the University of Miami', Labor Studies Journal 33(1) (2008), 63-80.

Alderman, Geoffrey, Modern British Jewry. Oxford, 1998.

Allen, Edward, et al., The North-East Engineers'Strikes of 1871: The Nine Hours' League. Newcastle upon Tyne, 1971.

Allen, John, and Nick Henry, 'Fragments of Industry and Employment: Contract Service Work and the Shift towards Precarious Employment', in Crompton, Gallie, and Purcell (eds), Changing Forms of Employment, 65-82.

Allen, John, and Nick Henry, 'Ulrich Beck's Risk Society at Work: Labour and Employment in the Contract Service Industries', Transactions of the Institute of British Geographers 22(2) (1997), 180-196.

Althammer, Beate, Herrschaft, Fürsorge. Protest. Eliten und Unterschichten in den Textilegewerbestädten Aachen und Barcelona 1830-1870. Bonn, 2002.

Alzaga, Valery, 'Justice for Janitors Campaign: Open-sourcing Labour Conflicts against Global Neoliberalism', OpenDemocracy, 7 February 2011 (https://www.opendemocracy.net/valery-alzaga/ justice-for-janitors-campaign-open-sourcing-labour-conflicts-against-global-neo-libera).

Amelina, Anna, et al. (eds), Beyond Methodological Nationalism: Research Methodologies for Cross-Border Studies. New York and Abingdon, 2012.

Ansell, C., Schism and Solidarity in Social Movements: The Politics of Labor in the French Third Republic. Cambridge, 2001.

Archer, Julian P.W., The First International in France 1864-1872: Its Origins, Theories, and Impact. Lanham, MD, etc., 1997.

Arnesen, Eric (ed.), Encyclopedia of US Labor and Working-Class History.3 vols. New York and London, 2007.

Arnold, Dennis, and Joseph R. Bongiovi, 'Precarious, Informalizing, and Flexible Work: Transforming Concepts and Understandings', American Behavioral Scientist 57(3) (2013), 289-308.

Arup, Christopher, et al. (eds), Labour Law and Labour Market Regulation: Essays on the Construction, Constitution and Regulation of Labour Markets and Work Relationships. Sydney, 2006.

Asaert, Gustaaf, 1585. De val van Antwerpen en de uittocht van Vlamingen en Brabanders. Tielt, 2004. Ashworth, John H., The Helper and American Trade Unions. Baltimore, 1915.

Aspromourgos, Tony, and John Lodewijks (eds), History and Political Economy: Essays in Honour of P.D. Groenewegen. London and New York, 2004. 
Baccaro, Lucio, and Chris Howell, 'A Common Neoliberal Trajectory: The Transformation of Industrial Relations in Advanced Capitalism', Politics and Society 39 (2011), 521-563.

Barbier, Jean-Claude, 'La précarité, une catégorie française à l'épreuve de la comparaison internationale', Revue française de sociologie 46 (2005), 351-371.

Barker, T.C., The Glassmakers. Pilkington: The Rise of an International Company $1826-1976$. London, 1977.

Barkhausen, Ernst, Die Tuchindustrie in Montjoie. Ihr Aufstieg und Niedergang. Aachen, 1925.

Becker, F., and J. Frieswijk, Bedrijven in eigen beheer. Kolonies en produktieve associaties in Nederland tussen 1901 en 1958. Nijmegen, 1976.

Beer, J.J.A. (Hans) de, 'Beroepskeuze, levensstandaard en lichamelijke ontwikkeling. De kleine sigarenmaker in Utrecht, ca. 1850', Tijdschrift voor Sociale Geschiedenis 19 (1993), 216-235.

Beiträge und Material zur Geschichte der Aachener Patrizier-Familien. Von Freiherrn Hermann Ariovist von Fürth. Dritter Band. Aachen, 1890.

Bekkum, R. van, Tussen Vraag en Aanbod. Op zoeknaar de identiteit van de arbeidsvoorzieningsorganisatie. The Hague, 1996.

Bengtsson, Erik, and Magnus Ryner, 'The (International) Political Economy of Falling Wage Shares: Situating Working-Class Agency', New Political Economy 20 (2015), 406-430.

Benöhr, H.-P. (ed.), Arbeitsvermittlung und Arbeitslosenversorgung in der neueren deutschen Rechtsgeschichte. Tübingen, 1991.

Bensimon, Fabrice, 'British Workers in France, 1815-1848', Past and Present 213 (2011), 147-189.

Bensimon, Fabrice, Quentin Deluermoz, and Jeanne Moisand (eds), Arise Ye Wretched of the Earth': The First International in a Global Perspective [Studies in Global Social History 29]. Leiden and Boston, 2018.

Berger, Françoise, et al. (eds), Industries, territoires et cultures en Europe du Nord-Ouest XIX-XXe siècles. Mélanges en l'honneur de Jean-François Eck. Roubaix, 2016.

Berger, Peter L. (ed.), The Human Shape of Work: Studies in the Sociology of Occupations. New York, 1964.

Berkvens, Louis, et al. (eds), Limburg, Een geschiedenis. Maastricht, 2015.

Bernaciak, Magdalena, Rebecca Gumbrell-McCormick, and Richard Hyman, European Trade Unionism: From Crisis to Renewal? Brussels, 2014.

Bernhardt, Annette, et al. (eds), The Gloves-offEconomy: Workplace Standards at the Bottom of America's Labor Market. Champaign, IL, 2008.

Bernstein, Deborah, 'The Subcontracting of Cleaning Work in Israel: A Case in the Casualisation of Labour', Sociological Review 34(2) (1986), 396-422.

Bernstein, Samuel, The First International in America. New York, 1965.

Béroud, S., and P. Bouffartigue (eds), Quand le travail se précarise, quelles résistances collectives? Paris, 2009.

Betti, Eloisa, 'Historicizing Precarious Work: Forty Years of Research in the Social Sciences and Humanities', International Review of Social History, 63(2) (2018), 273-319.

Bevaart, W., and S. Veen, De rechten man op de rechte plaats. De ontwikkeling van de openbare arbeidsbemiddeling in Amsterdam (1886-1940). Amsterdam, 1986.

Beveridge, W.H., Unemployment: A Problem of Industry, London, $1912^{3}$.

Biagini, Eugenio F., 'British Trade Unions and Popular Political Economy, 1860-1880', Historical Journal 30 (1987), 811-840.

Biografisch Woordenboek van het Socialisme en de Arbeidersbeweging in Nederland. 9 vols. Amsterdam, 1988-2003.

Blockmans, W.P., and L.A. van der Valk (eds), Van particuliere naar openbare zorg, en terug? Sociale politiek in Nederland sinds 1880. Amsterdam, 1992. 
Bloemgarten, Salvador, Henri Polak. Sociaal Democraat 1868-1943. The Hague, 1993.

Blok, Aad, et al. (eds), Generations in Labour History: Papers presented to the Sixth British-Dutch Conference on Labour History, Oxford 1988. Amsterdam, 1989.

Board of Trade, Report on Agencies and Methods for Dealing with the Unemployed (by H. Llewellyn Smith). London, 1893.

Böckler, Anita, et al. (eds), Regulation of Migration: International Experiences. Amsterdam, 1998.

Boersma, Jan, and Wil Remmers, 'De koöperatie: blauwdruk van een nieuwe samenleving of het paard van Troje? Een onderzoek naar de houding van Nederlandse socialisten ten opzichte van de koöperatie in de periode 1870-189o' (unpublished MA thesis, Utrecht University 1987).

Boll, Friedhelm, Arbeitskämpfe und Gewerkschaften in Deutschland, Engeland und Frankreich. Ihre Entwicklung vom 19. zum 20. Jahrhundert. Bonn, 1992.

Booth, Charles (ed.), Life and Labour of the People of London, vol. IV: The Trades of East London; vol. VII: Population Classified by Trades (continued); vol. VIII: Blocks of Buildings, Schools and Immigration. London, etc., 1892-1896.

Bos, Dennis, Waarachtige volksvrienden. De vroege socialistische beweging in Amsterdam 1848-1894. Amsterdam, 2001.

Boston, Sarah, Women Workers and the Trade Unions. London, 2015.

Bourdieu, Pierre, Firing Back: Against the Tyranny of the Market, Vol. 2. London and New York, 2003.

Bracey, Glenn Edward, 'Interracial Political Coalitions: An Analysis of Justice for Janitors Campaigns in Houston, TX' (MSc. thesis, Texas A\&M University, 2008).

Bremme, Peter, Ulrike Fürniß, and Ulrich Meinecke (eds), Never Work Alone: Organizing - ein Zukunftsmodell für Gewerkschaften. Hamburg, 2007.

Brentano, Lujo, On the History and Development of Gilds and the Origin of Trade-Unions. London, 1870.

Breuilly, John, 'Artisan Economy, Ideology and Politics: The Artisan Contribution to the MidNineteenth-Century European Labour Movement', in idem, Labour and Liberalism, 76-114.

Breuilly, John, Labour and Liberalism in Nineteenth-Century Europe: Essays in Comparative History. Manchester, 1994.

Bridges, Amy, 'The Sun Also Rises in the West', in Judd and Simpson (eds), The City, Revisited, 79-103.

Briggs, Asa, and John Saville (eds), Essays in Labour History: In Memory of G.D.H. Cole, 25 September 1889-14 January 1959. London, 1960.

Broadberry, Stephen, and Kevin O'Rourke (eds), The Cambridge Economic History of Modern Europe, Vol. 2: 1870 to the Present. Cambridge, 2010.

Bronfenbrenner, Kate (ed.), Global Unions: Challenging Transnational Capital through Cross-Border Campaigns. Ithaca, NY, and London, 2007.

Bronfenbrenner, Kate, et al. (eds), Organizing to Win:New Research on Union Strategies. Ithaca, NY, 1998.

Brosnan, Peter, and Frank Wilkinson, 'Low Pay and Industrial Relations: The Case of Contract Cleaning', New Zealand Journal of Industrial Relations 14(1) (1989), 83-89.

Bruhns, Julius, 'Es klingt im Sturm ein altes Lied!' Aus der Jugendzeit der Sozialdemokratie. Berlin, 1921.

Bruyne, R. De, and J. De Clerck, 'Le contrôle des chômeurs dans les caisses de chômage en Belgique', Rapport No. 10, in Compte rendu de la Conférence Internationale du Chômage. Tome deuxième III (1re partie).

Bücher, Karl, Die Entstehung der Volkswirtschaft. Vorträge und Aufsätze. Tübingen, $1926^{17}$.

Bücher, Karl, 'Die Gewerbliche Betriebssysteme in ihrer geschichtliche Entwicklung', in Die Entstehung der Volkswirtschaft, 161-196. 
Budde, Gunilla, et al. (eds), Transnationale Geschichte. Themen, Tendenzen und Theorien. Göttingen, 2006.

Burgdorf, Dagmar, Blauer Dunst und rote Fahnen. Ökonomische, soziale, politische und ideologische Entwicklung der Bremer Zigarrenarbeiterschaft im 19. Jahrhundert. Bremen, 1984.

Bürger, Heinrich, Die Hamburger Gewerkschaften und deren Kämpfe von 1865 bis 1890 . Hamburg, 1899 .

Buschak, Willy (ed.), Der Botschafter. Organ der deutschen Cigarrenarbeiter, 1867-1871. Ein Reprint der Gewerkschaft Nahrung-Genuss-Gaststätten. Hamburg, 1990.

Buschak, Willy, 'Einleitung: Friedrich Wilhelm Fritsche', in idem (ed.), Der Botschafter, ix-xv.

Buschak, Willy, Von Menschen, die wie Menschen leben wollen. Die Geschichte der Gewerkschaft Nahrung-Genuss-Gaststätte und ihrer Vorläufer. Cologne, 1985.

Buschman, M., “Eén doel, één wil”, of hoe de bakkersgezellen in de negentiende eeuw in verzet kwamen en een vakorganisatie oprichtten ter vestiging van het socialisme en hoe dat uitliep op centralisatie van de bond' (unpublished MA thesis University of Amsterdam, 1978).

Bustamente, Jorge A., Clark W. Reynolds, and Raúl A. Hinojosa Ojeda (eds), US-Mexico Relations: Labor Market Interdependence. Stanford, CA, 1992.

Bymholt, B., Geschiedenis der arbeidersbeweging in Nederland. Herdrukvan de editie van 1894 met een nieuw register en een biografische schets. Amsterdam, 1976.

Camp, R. op den, 'Heldt, Bernardus Hermanus', in Biografisch Woordenboekvan het Socialisme 6, 87-91. Campbell, Alan, Nina Fishman, and John McIlroy (eds), The High Tide of British Trade Unionism: Trade Unions and Industrial Politics 1964-79. London, 2007.

Campbell, Iain, and Manu Peeters, 'Low Pay, Compressed Schedules and High Work Intensity: A Study of Contract Cleaners in Australia', Australian Journal of Labour Economics 11(1) (2008), 27-46.

Casanovas, Joan, Bread, or Bullets! Urban Labor and Spanish Colonialism in Cuba, 1850-1898. Pittsburgh, 1998.

Chernilo, Daniel, 'Methodological Nationalism and its Critique', in Delanty and Kumar (eds), The Sage Handbook of Nations and Nationalism, 129-139.

Cillekens, Caspar, 'Aardewerk en arbeidsmarkt. Maastricht tussen de twee wereldoorlogen', Studies over de sociaaleconomische geschiedenis van Limburg/Jaarboek van het Sociaal Historisch Centrum voor Limburg $5^{2}$ (2007), 115-135.

Clawson, Dan, Bureaucracy and the Labor Process: The Transformation of US Industry, 1860-1920. New York, 1980.

Clawson, Dan, The Next Upsurge: Labor and the New Social Movements. Ithaca, NY, 2003.

CNRS (Centre national de la recherche scientifique), La Première Internationale. L'institution, l'implantation, le rayonnement. Paris, 1968.

Cobble, Dorothy Sue (ed.), The Sex of Work: Women Transforming American Labor. Ithaca, NY, and London, 2007.

Collins, Henry, 'The English Branches of the First International', in Briggs and Saville (eds), Essays in Labour History, 242-275.

Collins, Henry, 'The International and the British Labour Movement: Origin of the International in England', in CNRS, La Première Internationale, 23-40.

Collins, Henry, and Chimen Abramsky, Karl Marx and the British Labour Movement: Years of the First International. London, etc., 1965.

Compte rendu de la Conférence Internationale du Chômage, Paris 18-21 Septembre 1910, Tome deuxième III Rapports présentés à la Conférence par les sections nationales du Comité d'organisation. Paris, 1911. 
Connolly, Heather, 'Organizing and Mobilizing Precarious Workers in France: The Case of Cleaners in the Railways', in Thornley, et al., Globalization and Precarious Forms of Production and Employment, 182-198.

Connolly, Heather, et al., “Justice for Janitors” Goes Dutch: The Limits and Possibilities of Unions' Adoption of Organizing in a Context of Regulated Social Partnership', Work, Employment and Society 31 (2017), 319-335.

Connolly, Heather, et al., “Justice for Janitors” Goes Dutch: The Possibilities and Limitations of an Organising Approach in the Netherlands for a Sustained Union Renewal' (unpublished paper given at the British Universities Industrial Relations Association Conference, 7-9 July 2011, University of Greenwich, London).

Conrad, C., Die Organisation des Arbeitsnachweises in Deutschland. Leipzig, 1904.

Cooper, Patricia A., Once a Cigar Maker: Men, Women, and Work Culture in American Cigar Factories, 1900-1919. Urbana, IL, etc., 1987.

Cooper, Patricia, 'The "Traveling Fraternity”: Union Cigar Makers and Geographic Mobility, 1900-1919', Journal of Social History 17 (1983), 127-138.

Cordillot, Michel, Aux origines du socialisme moderne. La Première Internationale, la Commune de Paris, l'Exil. Paris, 2010.

Cordillot, Michel, 'La section française de l'Internationale et les grèves de 1867', in idem, Aux origines du socialisme moderne, 33-55.

Cordillot, Michel, La social en Amérique. Dictionnaire biographique du mouvement social francophone aux États-Unis, 1848-1922. Paris, 2002.

Cottereau, A., 'Droit et bon droit. Un droit des ouvriers instauré, puis évincé par le droit du travail (France, XIXe siècle)', Annales. Histoire, Sciences Sociales 57 (2002), 1521-1557.

Coyle, Angela, 'Going Private: The Implications of Privatization for Women's Work', Feminist Review 21 (1985), 5-23.

Cranford, Cynthia, 'Economic Restructuring, Immigration and the New Labor Movement: Latina/o Janitors in Los Angeles', Working Paper No. 9, Center for Comparative Immigration Studies, University of California. San Diego, 2000.

Cranford, Cynthia, 'Gender and Citizenship in the Restructuring of Janitorial Work in Los Angeles', Gender Issues 16(4) (1998), 25-51.

Cranford, Cynthia, ‘Gendered Resistance: Organizing Justice for Janitors in Los Angeles', in Stanford and Vosko (eds), Challenging the Market, 309-329.

Cranford, Cynthia, 'Labor, Gender and the Politics of Citizenship: Organizing Justice for Janitors in Los Angeles' (Ph.D. thesis, University of Southern California, 2001).

Crompton, Rosemary, Duncan Gallie, and Kate Purcell (eds), Changing Forms of Employment: Organisations, Skills and Gender. London, 1996.

Crosby, Michael, 'Clean Star: Fighting for a Fair Deal for Cleaners', in Gall (ed.), The Future of Union Organising, 131-149.

Crosby, Michael H., Power at Work: Rebuilding the Australian Union Movement. Annandale, NJ, 2005 .

Crouch, Colin, and Allessandro Pizzorno (eds), The Resurgence of Class Conflict in Western Europe since 1968. 2 vols. London, 1978.

Dahmen, Josef, Das Aachener Tuchgewerbe bis zum Ende des 19. Jahrhunderts. Ein Beitrag zur Wirtschaftsgeschichte der Stadt Aachen. Berlin, 1930.

Daniel, Evan Matthew, 'Rolling for the Revolution: A Transnational History of Cuban Cigar Makers in Havana, Florida and New York City' (Ph.D. dissertation, http://gradworks.umi. com/34/44/3444203.html), New York, 2010. 
Davids, Karel, and Bert De Munck (eds), Innovation and Creativity in Late Medieval and Early Modern European Cities. London, 2014.

Davis, Mike, Magical Urbanism: Latinos Reinvent the US City, London and New York, 2001.

Davis, Pearce, The Development of the American Glass Industry. Cambridge, MA, 1949.

Dearle, N.B., Problems of Unemployment in the London Building Trades. London, 1908.

Dechesne, Laurent, L'avènement du regime syndical à Verviers. Paris, 1908.

Dechesne, Laurent, Industrie drapière de la Vesdre avant 18oo. Paris and Liège, 1926.

Deconinck, Youssef, 'Diamantmigratie naar Antwerpen voor, tijdens en na de Kaapse Tijd. De Antwerpse diamantsector en zijn Amsterdamse migranten (1865-188o)' (unpublished MA thesis, Antwerp University, 2012).

Dekker, Rudolf, 'Arbeidsconflicten in de Leidse textielindustrie', in Diederiks, Noordam, and Tjalsma (eds), Armoede en sociale spanning, 69-86.

Dekker, Rudolf, “'Getrouwe broederschap”. Organisatie en acties van arbeiders in pre-industrieel Holland', Bijdragen en Mededelingen betreffende de Geschiedenis der Nederlanden 103 (1988), 1-19.

Dekker, Rudolf, 'Labour Conflicts and Working-Class Culture in Early Modern Holland', International Review of Social History 35(3) (1990), 377-420.

Delaet, Jean-Louis, 'La méchanisation de la verrerie à Vitres à Charleroi dans la première moitié du XXe siècle', in Kurgan-Van Hentenryk and Stengers (eds), L'innovation technologique, 113-152.

Delanty, Gerard, and Krishan Kumar (eds), The Sage Handbook of Nations and Nationalism. London, 2006.

della Porta, Donatella, et al. (eds), The New Social Division: Making and Unmaking Precariousness. Basingstoke, 2015.

Denis, Jean-Michel, 'Dans le nettoyage, c'est le chantier qui part en grève', in Béroud and Bouffartigue (eds), Quand le travail se précarise, 99-116.

Deslé, E., Arbeidsbemiddeling en/ofwerklozencontrole. Het voorbeeld van de Gentse arbeidsbeurs (1891-1914). Brussels, 1991.

Desmedt, Oscar, De Engelse natie te Antwerpen in de 16e eeuw (1496-1582). Antwerp, 1954.

Devreese, Daisy Eveline, 'Ambachten, arbeidsmarkt en arbeidersbeweging. Vorming van de moderne arbeidersbeweging te Brussel, 1842-1867', in De Vries, et al. (eds), De Kracht der Zwakken, 109-137.

Devreese, Daisy E., 'L'Association Internationale des Travailleurs. Bilan de l'historiographie, perspectives de recherche', Cahiers d'histoire de l'Institut de recherches marxistes 37 (1989), 9-31.

Devreese, Daisy E., 'An Inquiry into the Causes and Nature of Organization: Some Observations on the International Working Men's Association, 1864-1872/1876', in Van Holthoon and Van der Linden (eds), Internationalism in the Labour Movement, I, 284-303.

Devreese, Daisy E., “Ein seltener Mann”. Johann Philipp Becker und die Internationale ArbeiterAssoziation', in Hahn (ed.), Johann Philipp Becker, 113-128.

Dhondt, Jan, 'Rapport de synthèse', in CNRS, La Première Internationale, 463-484.

Diederiks, H.A., D.J. Noordam, and H.D. Tjalsma (eds), Armoede en sociale spanning. Sociaalhistorische studies over Leiden in de achttiende eeuw [Hollandse Studiën 17]. Hilversum, 1985.

Dieteren, Remigius, Mens en mijn. Een halve eeuw strijd, groei en bloei van de Nederlandse Katholieke Mijnwerkersbond. Heerlen, 1953.

Documents relatifs aux militants belges de l'Association Internationale des Travailleurs. Correspondance 1865-1872. Textes réunis, établis et annotés par Daisy Eveline Devreese. Louvain, etc., 1986.

Donoghue, Mark, 'Marx on the Wages Fund Doctrine: A Comment', Revue d'économie politique 105 (1995), 345-352. 
Donoghue, Mark, 'Mill's Affirmation of the Classical Wage Fund Doctrine', Scottish Journal of Political Economy 44 (1997), 82-99.

Donoghue, Mark, 'William Thomas Thornton and John Stuart Mill: A Victorian Friendship', in Aspromourgos and Lodewijks (eds), History and Political Economy, 76-96.

Douglas, Mary, Purity and Danger: An Analysis of Concepts of Pollution and Taboo. London, 1966.

Dreyfus, M., et al., 'Les bases multiples du syndicalisme au XIXe siècle en Allemagne, France et Grande-Bretagne', in Robert, Boll, and Prost (eds), L'invention des syndicalismes, 269-284.

Dubofsky, Melvyn, and Warren Van Tine (eds), Labor Leaders in America. Urbana and Chicago, 1987.

Duckworth, G.H., and Harold Hardy, 'Brewers and Tobacco Workers', in Booth (ed.), Life and Labour of the People of London, vol. VII, 115-142.

Ebeling, Dietrich, 'Entstehungs- und Existenzbedingungen regionaler Arbeitsmärkte im Übergang von der Protoindustrie zur frühen Fabrikindustrie. Das Beispiel der Feintuchregion Aachen', in Häberlein and Jeggle (eds), Vorindustrielles Gewerbe, 109-144.

Ebeling, Dietrich, and Wolfgang Mager (eds), Protoindustrie in der Region. Europäische Gewerbelandschaften vom 16. bis zum 19. Jahrhundert. Bielefeld, 1997.

Ebeling, Dietrich, and Martin Schmidt, 'Zünftige Handwerkswirtschaft und protoindustrieller Arbeitsmarkt. Die Aachener Tuchregion (1750-1815)', in idem and Mager (eds), Protoindustrie in der Region, 321-346.

Edling, N., 'Regulating Unemployment the Continental Way: The Transfer of Municipal Labour Exchanges to Scandinavia 1890-1914', European Review of History/Revue européenne d'Histoire 15 (2008), 23-40.

Eeckhout, P. Van den (ed.), Supervision and Authority in Industry: Western European Experiences, 1830-1939 [International Studies in Social History 15]. Oxford and NewYork, 2009.

Ehmer, J., Soziale Traditionenin Zeiten des Wandels. Arbeiter und Handwerker im 19. Jahrhundert [Studien zur Historischen Sozialwissenschaft 2o]. Frankfurt am Main and New York, 1994.

Ehmer, J., 'Tramping Artisans in Nineteenth-Century Vienna', in Siddle (ed.), Migration, Mobility and Modernity, 164-185.

Eichhorst, Werner, and Paul Marx (eds), Non-Standard Employment in Post-Industrial Labour Markets: An Occupational Perspective. Cheltenham, 2015.

Eisenberg, Christiane, Deutsche und englische Gewerkschaften. Entstehung und Entwicklung bis 1878 im Vergleich. Göttingen, 1986.

Eisenberg, Christiane, Frühe Arbeiterbewegung und Genossenschaften. Theorie und Praxis der Produktivgenossenschaften in der deutschen Sozialdemokratie und den Gewerkschaften der 186oer/1870er Jahre. Bonn, 1985 .

Ekelund, R.B., 'A Short-run Classical Model of Capital and Wages: Mill's Recantation of the Wages Fund', Oxford Economic Papers 28 (1976), 66-85.

Elbaum, Bernard, and Frank Wilkinson, 'Industrial Relations and Uneven Development: A Comparative Study of the American and British Steel Industries', Cambridge Journal of Economics 3 (1979), 275-303.

Engelberg, Ernst, and R. Dlubek, 'Le mouvement ouvrier allemand et la Première Internationale', in CNRS, La Première Internationale, 168-191.

Engelhardt, Ulrich, 'Nur vereinigt sind wir stark'. Die Anfänge der deutschen Gewerkschaftsbewegung $1862 / 63$ bis $1869 / 70$. Stuttgart, 1977.

Engelhardt, Ulrich, 'Zur Entwicklung der Streikbewegungen in der ersten Industrialisierungsphase und zur Funktion von Streiks bei der Konstituierung der Gewerkschaftsbewegung in Deutschland', Internationale Wissenschaftliche Korrespondenz zur Geschichte der deutsche Arbeiterbewegung 15 (1979), 547-569. 
Engels, Albert, Die Zollgrenze in der Eifel. Eine wirtschaftsgeschichtliche Untersuchung für die Zeit von 1740 bis 1834 [Schriften zur rheinisch-westfälischen Wirtschaftsgeschichte Neue Folge 2]. Cologne, 1959 .

Englander, Ernest J., 'The Inside Contract System of Production and Organization: A Neglected Aspect of the History of the Firm', Labor History 28 (1987), 429-446.

Enquête gehouden door de Staatscommissie benoemd krachtens de wet van 19 januari 1890 (Staatsblad no. 1), afd. III, Amsterdam. N.p., n.d.

Erikson, Christopher L., et al., 'Justice for Janitors in Los Angeles: Lessons from Three Rounds of Negotiations', British Journal of Industrial Relations 40(3) (2002), 543-567.

Erikson, Christopher L., et al., 'Justice for Janitors in Los Angeles and Beyond: A New Form of Unionism in the Twenty-First Century?', in Wunnava (ed.), The Changing Role of Unions, 22-58.

Esping-Andersen, G., The Three Worlds of Welfare Capitalism. Princeton, NJ, 1990.

Evert, G., 'Die Arbeitsvermittlung in Preußen während des Jahres 1894', Ztschr. Des Kgl. Preußischen Stat. Bureaus 36 (1896).

Fairbrother, Peter, Marc-Antonin Hennebert, and Christian Lévesque (eds), Transnational Trade Unionism: Building Labour Power. New York and Abingdon, 2013.

Fairon, M.E., 'Les industries du Pays de Verviers', Bulletin de la Société verviétoise d'archéologie et d'histoire 43 (1956), 15-42.

Fairon, M.E., 'La question ouvrière au XVIIIe siècle dans la vallée de la Vesdre', in Chronique de la Société verviétoise d'Archéologie et d'Histoire 1905 à 1911 (Verviers, n.d.), 43-58.

Farnham, David, 'Beatrice and Sidney Webb and the Intellectual Origins of British Industrial Relations', Employee Relations 30 (2008), 534-552.

Farr, James R., Artisans in Europe 1300-1914. Cambridge, 2000.

Faust, A., 'Arbeitsmarktpolitik in Deutschland. Die Entstehung der öffentlichen Arbeitsvermittlung 1890-1927', in Pierenkemper and Tilly (eds), Historische Arbeitsmarktforschung, 253-273.

Faust, A., Arbeitsmarktpolitik im deutschen Kaiserreich Arbeitsvermittlung, Arbeitsbeschaffung und Arbeitslosenunterstützung 189o-1918 [VSWG Beihefte 79]. Stuttgart, 1986.

Faust, A., 'Arbeitsvermittlung und Arbeitslosenversorgung in Deutschland von der Mitte des 19. Jahrhunderts bis zum Ende des Kaiserreichs', in Benöhr (ed.), Arbeitsvermittlung und Arbeitslosenversorgung, 105-135.

Fernie, Sue, and David Metcalf (eds), Trade Unions: Resurgence or Demise? London and New York, 2005 .

Fichter, Michael, and Jamie McCallum, 'Implementing Global Framework Agreements: The Limits of Social Partnership', Global Networks: A Journal of Transnational Affairs 15 (2015), suppl., $65-85$.

Fink, Leon (ed.), Workers across the Americas: The Transnational Turn in Labor History. Oxford, 2011.

Fones-Wolf, Ken, 'From Craft to Industrial Unionism in the Window-Glass Industry: Clarksburg, West Virginia, 1900-1937', Labor History 37 (1995), 28-49.

Fones-Wolf, Ken, Glass Towns: Industry, Labor, and Political Economy in Appalachia, 189o-193os. Urbana, IL, 2007.

Fones-Wolf, Ken, 'Immigrants, Labor and Capital in a Transnational Context: Belgian Glass Workers in America, 1880-1925', Journal of American Ethnic History 21 (2002), 59-80.

Fones-Wolf, Ken, 'Transatlantic Craft Migrations and Transnational Spaces: Belgian Window Glass Workers in America, 1880-1920', Labor History 45 (2004), 299-321.

Fontana, Natale, 'A Comparative Analysis on Trade Union Approaches to Precarious Work in the Cleaning Sector Using the Examples of the US, Germany and the Netherlands' (MA thesis, Berlin School of Economics and Law, 2012). 
Foster, Jason, and Bob Barnetson, 'Justice for Janitors in Alberta: The Impact of Temporary Foreign Workers on an Organizing Campaign', Journal of Workplace Rights 16(1) (2011-2012), 3-29.

Fox, Alan, 'Collective Bargaining, Flanders, and the Webbs', British Journal of Industrial Relations 13 (1975), 151-174.

Fox, Stephen N., 'Tobacco Workers', in Booth (ed.), Life and Labour of the People of London, vol. IV, 370-388.

Frade, Carlos, and Isabelle Darmon, 'New Modes of Business Organization and Precarious Employment: Towards the Recommodification of Labour?', Journal of European Social Policy 15 (2005), 107-121.

Freeman, Richard, and James Medoff, What Do Unions Do? New York, 1984.

Frege, Carola, and John Kelly (eds), Varieties of Unionism: Comparative Strategies for Union Renewal. Oxford, 2004.

Fremdling, Rainer, ‘The Puddler: A Craftsman's Skill and the Spread of a New Technology in Belgium, France and Germany', Journal of European Economic History 20 (1991), 529-567.

French, John D., 'Another World History Is Possible: Reflections on the Translocal, Transnational, and Global', in Fink (ed.), Workers across the Americas, 3-11.

Frisch, Walther, Die Organisationsbestrebungen der Arbeiter in der deutschen Tabak-industrie. Leipzig, 1905 .

Fuster, E., 'L'assurance contre le chômage et le contrôle', Rapport No. 23, in Compte rendu de la Conférence Internationale du Chômage. Tome deuxième III (1re partie).

Gahan, Peter, 'Trade Unions as Regulators: Theoretical and Empirical Perspectives', in Arup, et al. (eds), Labour Law and Labour Market Regulation, 261-281.

Gales, Ben, Delven en slepen. Steenkolenmijnbouw in Limburg: techniek, winning en markt gedurende de achttiende en negentiende eeuw. Hilversum, 2004.

Gales, Ben, 'Goed betaald? Mijnwerkerslonen en arbeidsmarkt in het Nederlands-Duits-Belgische grensgebied in de achttiende en negentiende eeuw', Studies over de sociaal-economische geschiedenis van Limburg/Jaarboek van het Sociaal Historisch Centrum voor Limburg 53 (2008), 57-87.

Gall, Gregor (ed.), The Future of Union Organising: Building for Tomorrow. Basingstoke, 2009.

Gallisot, René, 'La patrie des prolétaires', Le Mouvement Social 147 (1989), 11-25.

Garcia Galló, Gaspar Jorge, El tabaquero cubana. Psicologiá de las profesiones. Havana, 1936.

Gayot, Gérard, Les draps de Sedan 1646-1870. Paris, 1998.

Gayot, Gérard, 'La longue insolence des tondeurs de draps dans la manufacture de Sedan au XVIème siècle', Revue du Nord 63(248) (1981), 105-134.

Gayot, Gérard, 'Les “ouvriers les plus nécessaires" sur le marché du travail des manufactures de draps au XVII-XVIIIe siècle', in idem and Minard (eds), Les ouvriers qualifiés de l'industrie, 209-237.

Gayot, Gérard, and Philippe Minard (eds), Les ouvriers qualifiés de l'industrie (XVIe-XXe siècles). Formations, emploi, migrations [Revue du Nord, Hors-série Histoire no. 15]. Villeneuve-d'Ascq, 2001.

Gelderblom, Oscar, Zuid-Nederlandse kooplieden en de opkomst van de Amsterdamse stapelmarkt (1578-163o). Hilversum, 2000.

Gennep, A. Van, Manuel de folklore français contemporain I. Paris, 1949.

Gerth, Hans H., 'The Retreat from Ideology as a Prerequisite for American Trade-Unions', in CNRS, La Première Internationale, 403-413.

Geschichte von Vaals. Beiträge aus den Aufzeichnungen A. Vaessen. Vaals, 1925.

Gewin, B., Arbeidsbeurzen. Utrecht, 1898. 
Giele, Jacques J., De Eerste Internationale in Nederland. Een onderzoek naar het ontstaan van de Nederlandse arbeidersbeweging van 1868 tot 1876 . Nijmegen, 1973.

Giele, J.J. (ed.), Een kwaad leven. Heruitgave van de Enquête betreffende werking en uitbreiding der wetvan 19 september 1874 (Staatsblad no. 130) en naar de toestand van fabrieken en werkplaatsen. Nijmegen, 1981.

Giele, J.J., 'Het ontstaan van de typografen-vakorganisatie in Nederland (1837-1869)', Mededelingenblad. Orgaan van de Nederlandse Vereniging tot beoefening van de Sociale Geschiedenis 42 (1972), 2-55.

Giele, Jacques, 'Socialisme en vakbeweging. De opkomst van socialistische vakorganisaties in Nederland (1878-1890). Deel 1', Jaarboekvoor de geschiedenis van socialisme en arbeidersbeweging in Nederland (1978), 27-82.

Giele, Jacques, 'Willem Ansing en de oprichting van de Sociaal-Demokratische Vereeniging in 1878', Jaarboek voor de Geschiedenis van Socialisme en Arbeidersbeweging in Nederland 1 (1976), 180-212.

Gitelman, H.M., 'Adolph Strasser and the Origins of Pure and Simple Unionism', Labor History 6 (1965), 71-83.

Goedhard, Noor, and Kea Tijdens, Beroepsbinding en vakbondsoriëntatie in de schoonmaak. Een onderzoek in opdracht van de Industriebond FNV naar de vakbondsoriëntatie van werknemers in de schoonmaaksector. Amsterdam, 1993.

Goethem, Geert van, The Amsterdam International: The World of the International Federation of Trade Unions (IFTU), 1913-1945. Aldershot, 1988.

Gold, Raymond L., 'In the Basement: The Apartment Building Janitor', in Berger (ed.), The Human Shape of Work, 1-49.

Gompers, Samuel, Seventy Years of Life and Labor, 2 vols. New York, 1925.

Goodwin, Jeff, and James M. Jasper (eds), The Social Movements Reader: Cases and Concepts. Chichester, 2009.

Gordon, Colin, New Deals: Business, Labor, and Politics in America, 1920-1935. Cambridge, 1994.

Gospel, Howard, 'The Development of Management Organization in Industrial Relations: A Historical Perspective', in Thurley and Wood (eds), Industrial Relations and Management Strategy, 91-110.

Gourevitch, Alex, From Slavery to the Cooperative Commonwealth: Labor and Republican Liberty in the Nineteenth Century. Cambridge, 2015.

Grießinger, Andreas, Das symbolische Kapital der Ehre. Streikbewegungen und kollektives Bewußtsein deutscher Handwerksgesellen im 18. Jahrhundert. Frankfurt am Main, 1981.

Griffiths, C., J. Nott, and W. Whyte (eds), Classes, Cultures and Politics: Essays for Ross McKibbin. Oxford, 2011.

Gruner, Erich, 'Arbeitsvermittlung und Arbeitslosenversorgung. Das Beispiel der Schweiz', in Benöhr (ed.), Arbeitsvermittlung und Arbeitslosenversorgung, 237-256.

Gumbrell-McCormick, Rebecca, and Richard Hyman, Trade Unions in Western Europe: Hard Times, Hard Choices. Oxford, 2013.

Häberlein, Mark, and Christof Jeggle (eds), Vorindustrielles Gewerbe. Handwerkliche Produktion und Arbeitsbeziehungen im Mittelalter und früher Neuzeit. Konstanz, 2004.

Haesenne-Peremans, Nicole, La pauvreté dans la région liégeoise à l'aube de la révolution industrielle. Un siècle de tension sociale (1730-1830). Paris, 1981.

Hahn, Hans-Werner (ed.),Johann Philipp Becker. Radikaldemokrat-Revolutionsgeneral-Pionier der Arbeiterbewegung. Stuttgart, 1999.

Hall, Peter, and David Soskice, Varieties of Capitalism: The Institutional Foundations of Comparative Advantage. Oxford, 2001. 
Hamelin, D., 'Dossier: Aux sources de l'histoire syndicale française, retour sur les Bourses du travail', Cahiers d'Histoire. Revue d'histoire critique 116-117 (2011), 11-162.

Hammond, J.L., and Barbara Hammond, The Skilled Labourer 1760-1832. London, 1919.

Hanagan, Michael P., 'An Agenda for Transnational Labor History', International Review of Social History 49(3) (2004), 455-474.

Harison, C., 'The Rise and Decline of a Revolutionary Space: Paris' Place de Grève and the Stonemasons of Creuse, 1750-1900', Journal of Social History 34 (2000), 403-436.

Harreld, Donald J., High Germans in the Low Countries: German Merchants and Commerce in Golden Age Antwerp. Leiden and Boston, 2004.

Harris, J., Unemployment and Politics: A Study in English Social Policy 1886-1914. Oxford, 1972.

Harrison, Royden, and Jonathan Zeitlin (eds), Divisions of Labour: Skilled Workers and Technological Change in Nineteenth-Century England. Brighton, 1985.

Hart, P.D. 't, 'Brieven van J.Th. Potharst aan de “Maatschappij rot Nut van 't Algemeen” in 1874', Tijdschrift voor Sociale Geschiedenis 7 (1981), 72-86.

Hattam, Victoria C., Labor Visions and State Power: The Origins of Business Unionism in the United States. Princeton, NJ, 1994.

Hatzfeld, Nicolas, Michel Pigenet, and Xavier Vigna (eds), Travail, travailleurs et ouvriers d'Europe au XXe siècle. Dijon, 2016.

Hearn, Julie, and Monica Bergos, 'Latin American Cleaners Fight for Survival: Lessons for Migrant Activism', Race and Class 53(1) (2011), 65-82.

Heerma van Voss, Lex, Patrick Pasture, and Jan De Maeyer (eds), Between Cross and Class: Comparative Histories of Christian Labour in Europe 1840-2000. Bern, etc., 2005.

Heery, Edmond, and Brian Abbott, 'Trade Unions and the Insecure Workforce', in idem and Salmon (eds), The Insecure Workforce, 155-180.

Heery, Edmond, and John Salmon (eds), The Insecure Workforce. London, 2000.

Heldt, B.H., Algemeen Nederlandsch Werklieden-Verbond 1871-1896. Leeuwarden, 1896.

Henkel, Martin, 'Taglohn, Tradition und Revolution. Ein Tarifvertrag aus dem Jahre 179o', Internationale wissenschaftliche Korrespondenz zur Geschichte der deutschen Arbeiterbewegung 19(1) (1989), 42-66.

Henkel, Martin, and Rolf Taubert, Maschinenstürmer. Ein Kapitel aus der Sozialgeschichte des technischen Fortschritts. Frankfurt, 1979.

Hennock, E.P., 'Lessons from England: Lujo Brentano on British Trade Unionism', German History 11 (1993), 141-16o.

Hermanns, Leo, 'Die Tuchscherer. Eupens erste solidarische Arbeiterschaft', Geschichtliches Eupen 16 (1982), 150-171.

Heuts, Pien, “'No More Being Ground Down for Us”: Dutch Cleaners Up in Arms', HesaMag 2 (2010), 27-31.

Heuts, Pien, Tegenmacht. Utrecht, 2011.

Hiepel, Claudia, Arbeiterkatholizismus an der Ruhr. August Brust und der Gewerkverein christlicher Bergarbeiter. Stuttgart, 1999.

Hirschman, Albert, Exit, Voice, and Loyalty: Responses to Decline in Firms, Organizations, and States. Cambridge, MA, 1970.

Hobsbawm, Eric J., 'Artisan or Labour Aristocrat', Economic History Review, 2nd ser. 37 (1984), 355-372.

Hobsbawm, Eric, 'The Labour Aristocracy in Nineteenth-Century Britain', in Labouring Men, 272-315.

Hobsbawm, Eric J., Labouring Men: Studies in the History of Labour. London, $1979^{6}$.

Hobsbawm, Eric, 'The Machine Breakers', Past and Present 1 (1952), 57-70. 
Hobsbawm, Eric J., 'The New Unionism Reconsidered', in Mommsen and Husung (eds), The Development of Trade Unionism, 14-31.

Hobsbawm, E.J., 'Trade Union Historiography', Bulletin of the Society for the Study of Labour History 8 (1964), 31-36.

Hobsbawm, Eric J., 'The Tramping Artisan', in Labouring Men, 34-63.

Hobsbawm, Eric J., Uncommon People: Resistance, Rebellion and Jazz. London, 1998.

Hobsbawm, Eric J., and Joan W. Scott, 'Political Shoemakers', in Hobsbawm, Uncommon People, 18-43 [orig. Past and Present 89 (1980)].

Hoekman, Piet, and Jannes Houkes, Het Nationaal Arbeids-Secretariaat 1893-1940. De geschiedenis van de eerste vakcentrale in Nederland. Amsterdam, 2015.

Hoerder, Dirk, and Jörg Nagler (eds), People in Transit: German Migrations in Comparative Perspective, 1820-1930. Cambridge, 1995 .

Hoeven, W. van der, De Nederlandsche Sigarenmakers- en Tabakbewerkersbond, opgericht op 26 december 1887. Zijn geschiedenis, werken en streven. Amsterdam, 1937.

Hofmeester, Karin, Jewish Workers and the Labour Movement: A Comparative Study of Amsterdam, London, and Paris. Aldershot, 2004.

Hofmeester, Karin, and Marcel van der Linden (eds), Handbook Global History of Work. Oldenbourg, 2018.

Holgate, Jane, 'Unionising the Low Paid in London. The Justice for Cleaners Campaign: A Case Study' (unpublished paper, February 2009).

Holley, Sasha, and Al Rainnie, 'Who Cleans Up? The Declining Earnings Position of Cleaners in Australia', Economic and Labour Relations Review 23(1) (2012), 143-160.

Holthoon, Frits van, and Marcel van der Linden (eds), Internationalism in the Labour Movement 1830-1940, 2 vols. Leiden, 1988.

Hoogenboom, Marcel, 'Transnational Unemployment Insurance: The Inclusion and Exclusion of Foreign Workers in Labour Unions' Unemployment Insurance Funds in the Netherlands (c.1900-1940)', International Review of Social History ${ }_{5} 8(2)$ (2013), 247-284.

Horn, Jeff, The Path Not Taken: French Industrialization in the Age of Revolution 1750-1830. Cambridge, MA, and London, 2006.

Horssen, P. van, and D. Rietveld, 'De SDB. Organisatie en ledenaanhang' (unpublished MA thesis, Utrecht University, 1974).

Horssen, Paul van, and Dick Rietveld, 'De Sociaal Democratische Bond. Een onderzoek naar het ontstaan van haar afdelingen en haar sociale structuur', Tijdschrift voor Sociale Geschiedenis $1(1975), 5^{-71}$.

Horssen, P. van, and D. Rietveld, 'Socialisten in Amsterdam 1878-1898. Een sociaal profiel van de SDB- en SDAP-aanhang', Tijdschrift voor Sociale Geschiedenis 16 (1990), 387-406.

Hovens, Frank, 'De komst van lakenfabrikant Johann Arnold Clermont naar Vaals', Historische en Heemkundige Studies in en rond het Geuldal 8 (1998), 221-258.

Howley, John, 'Justice for Janitors: The Challenge of Organizing in Contract Services', Labor Research Review 1(15) (1990), 61-71.

Hudig, Dirk, De vakbeweging in Nederland 1866-1878. Amsterdam, 1904.

Huss, G., 'La question du chômage en Suède', Rapport No. 43, in Compte rendu de la Conférence Internationale du Chômage. Tome deuxième III (1re partie).

Hutt, W.H., The Theory of Collective Bargaining. London, 1975; orig. 1930.

Hyman, Richard, Understanding European Trade Unionism: Between Market, Class and Society. London, 2001. 
Imle, F., 'Die Ergebnisse der Gewerkschaftlichen Arbeitslosenunterstützung', Sozialistische Monatshefte 6 (1902), 800-809.

Institut für Marxismus-Leninismus beim ZK der SED, Die Internationale in Deutschland (1864-1872). Dokumente und Materialien. Berlin, 1964.

Institute of Marxism-Leninism of the CC, CPSU, Documents of the First International: The Hague Congress of the First International September 2-7, 1872. Minutes and Documents. Moscow, 1976. Institute of Marxism-Leninism of the CC, CPSU, Documents of the First International: The Hague Congress of the First International September 2-7, 1872. Reports and Letters. Moscow, 1978.

Isacker, Karel Van, De Internationale te Antwerpen 1867-1877. Antwerp, 1964.

Jackson, Ben, 'Hayek, Hutt and the Trade Unions', in Leeson (ed.), Hayek: A Collaborative Biography, 208-228.

Jackson, Ben, 'An Ideology of Class: Neo-Liberalism and the Trade Unions, c. 1930-79', in Griffiths, Nott, and Whyte (eds), Classes, Cultures and Politics, 263-281.

Jackson, Ben, 'Neoliberalism, Labour and Trade Unionism', in Springer, Birch, and MacLeavy (eds), The Handbook of Neoliberalism, 262-270.

Jacobs, Jac., Het gouden boek der KAB in Limburg. Vijftig jaren arbeidersbeweging in Limburg. Heerlen, 1951.

Jacquemyns, G., Enquête sur les conditions de vie de familles ouvrières du bassin de Charleroi en 1933. Liège, 1934.

Jaffe, James A., Striking a Bargain: Work and Industrial Relations in England 1815-1865. Manchester, 2000.

Janssens, Valéry, Het geldwezen der Oostenrijkse Nederlanden. Brussels, 1957.

Jarrige, François, Au temps des 'tueuses de bras'. Les bris de machines à l'aube de l'ère industrielle. Rennes, 2009.

Jarrige, François, 'Les tondeurs européens à l'épreuve des méchaniques. Approche comparée des négociations sociotechniques dans l'industrie lainière (1750-1850)', in Maitte, Minard, and De Oliveira (eds), La gloire de l'industrie, 279-297.

Jihye Chun, Jennifer, Organizing at the Margins: The Symbolic Politics of Labor in South Korea and the United States. Ithaca, NY, and London, 2009.

Jong, Frits de, Om de plaats van de arbeid. Een geschiedkundig overzicht van het ontstaan en de ontwikkeling van het Nederlands Verbond van Vakverenigingen. Amsterdam, 1956.

Joyce, Patrick (ed.), The Historical Meanings of Work. Cambridge, 1987.

Judd, Dennis R., and Dick Simpson (eds), The City, Revisited: Urban Theory from Chicago, Los Angeles, and New York. Minneapolis, 2011.

Kaiserliches Statistisches Amt, Die Versicherung gegen die Folgen der Arbeitslosigkeit im Ausland und im Deutschen Reich. Berlin, 1906.

Kalleberg, Arne L., Good Jobs, Bad Jobs: The Rise of Polarized and Precarious Employment Systems in the United States, 1970 s to 200os, New York, 2011.

Kalleberg, Arne L., 'Precarious Work, Insecure Workers: Employment Relations in Transition', American Sociological Review 74(1) (2009), 1-22.

Kaplan, S.L., 'La lutte pour le contrôle du marché du travail à Paris au XVIIIe siècle', Revue d'histoire moderne et contemporaine 36 (1989), 361-412.

Kaplan, Steven L., and Cynthia J. Koepp (eds), Work in France: Representations, Meaning, Organization, and Practice. Ithaca, NY, and London, 1986.

Kaptein, Herman, De Hollandse textielnijverheid 1350-16oo. Conjunctuur \& continuïteit. Hilversum, 1998. 
Karl Marx Friedrich Engels Gesamtausgabe I. Berlin, 1978.

Katz, Henryk, The Emancipation of Labor: A History of the First International. New York, 1992.

Kaufman, Bruce, 'The Early Institutionalists on Industrial Democracy and Union Democracy', Journal of Labor Research 21 (2000), 189-209.

Kaufman, Bruce E., 'History of the British Industrial Relations Field Reconsidered: Getting from the Webbs to the New Employment Relations Paradigm', British Journal of Industrial Relations $5^{2}$ (2014), 1-31.

Kermann, Joachim, Die Manufakturen im Rheinland 1750-1833. Bonn, 1972.

Keune, Maarten, 'Trade Union Responses to Precarious Work in Seven European Countries', International Journal of Labour Research 5(1) (2013), 59-78.

Keune, Maarten, 'Trade Unions, Precarious Work and Dualisation in Europe', in Eichhorst and Marx (eds), Non-Standard Employment, 378-400.

King, D., Actively Seeking Work? The Politics of Unemployment and Welfare Policy in the United States and Great Britain. Chicago and London, 1995.

King, D., and B. Rothstein, 'Government Legitimacy and the Labour Market: A Comparative Analysis of Employment Agencies', Public Administration 72 (1994), 291-308.

King, D., and B. Rothstein, 'Institutional Choices and Labour Market Policy: A British-Swedish Comparison', Comparative Political Studies 26 (1993), 291-308.

Kirk, Neville, Donald M. MacRaild, and Melanie Nolan, 'Introduction: Transnational Ideas, Activities, and Organizations in Labour History', Labour History Review 74 (2009), 221-232.

Kirk, Neville, Donald M. MacRaild, and Melanie Nolan, 'Transnational Labour in the Age of Globalization', Labour History Review 75 (2010), 8-19.

Kisch, Herbert, 'Das Erbe des Mittelalters, ein Hemmnis wirtschaftlicher Entwicklung: das Tuchgewerbe im Aachener Raum vor 179o', in idem, Die hausindustriellen Textilgewerbe am Niederrhein, 258-316.

Kisch, Herbert, Die hausindustriellen Textilgewerbe am Niederrhein vor der industriellen Revolution. Von der ursprünglichen zur kapitalistischen Akkumulation. Göttingen, 1981.

Kitschelt, Herbert, et al. (eds), Continuity and Change in Contemporary Capitalism. Cambridge, 1999.

Klank, Kristin, 'Secondary Labour Force or Permanent Staff? Foreign Workers in the Aachen Coal Mines', Tijdschrift voor Sociale en Economische Geschiedenis 5 (2008), 126-154.

Klaveren, Maarten van, and Wim Sprenger, 'Union Organising in the Netherlands. A Combination of Organising and Servicing Strategies', in Gall, The Future of Union Organising, 62-78.

Kleßmann, Eckart, Geschichte der Stadt Hamburg. Hamburg, 1981.

Kloosterboer, Dirk, De vakbeweging van de toekomst. Lessen uit het buitenland. Amsterdam, 2005.

Klüss, Franz, Die älteste deutsche Gewerkschaft. Die Organisation der Tabak-und Zigarrenarbeiter bis zum Erlasse des Sozialistengesetzes. Karlsruhe, 1905.

Knotter, Ad, 'De Amerikaanse en Belgische vensterglasindustrie en de Nederlandse diamantindustrie (ca. 1880-1940). Vakbonden, arbeidsorganisatie en marktverhoudingen', Brood \& Rozen. Tijdschrift voor de Geschiedenis van Sociale Bewegingen 31 (2012), 5-37.

Knotter, Ad, 'De Amsterdamse bouwnijverheid in de 19e eeuw tot ca. 1870. Loonstarheid en trekarbeid op een dubbele arbeidsmarkt', Tijdschrift voor Sociale Geschiedenis 10 (1984), 123-154.

Knotter, Ad, 'Het Boschstraatkwartier in Maastricht in de eerste decennia van de twintigste eeuw. Een socialistisch (vrouwen)bolwerk', Stadsgeschiedenis 11 (2016), 24-48.

Knotter, Ad, 'Changing Border Regimes, Mining, and Cross-Border Labor in the Dutch-BelgianGerman Borderlands, 1900-1973', Journal of Borderlands Studies 29 (2014), 375-384.

Knotter, Ad, 'Du contrôle des services de placements au contrôle des chômeurs. L'intégration des syndicats dans les agences publiques pour l'emploi en Europe occidentale au début du XXe siècle', in Hatzfeld, Pigenet, and Vigna (eds), Travail, travailleurs et ouvriers d'Europe, 297-308. 
Knotter, Ad, Economische transformatie en stedelijke arbeidsmarkt. Amsterdam in de tweede helft van de negentiende eeuw. Zwolle and Amsterdam, 1991.

Knotter, Ad, 'From Placement Control to Control of the Unemployed: Trade Unions and Labour Market Intermediation in Western Europe in the Nineteenth and Early Twentieth Centuries', in Wadauer, Buchner, and Mejstrik (eds), The History of Labour Intermediation, 117-150.

Knotter, Ad, 'Grenzen aan de loonpolitiek. De langzaam-aan-actie van de Nederlandse Katholieke Mijnwerkers Bond (1957) tussen nationale integratie, grensligging en katholiek regionalisme', Studies over de sociaaleconomische geschiedenis van Limburg/Jaarboek van het Sociaal Historisch Centrum voor Limburg 53 (2008), 117-157.

Knotter, Ad, 'Justice for Janitors Goes Dutch. Precarious Labour and Trade Union Response in the Cleaning Industry (1988-2012): A Transnational History', International Review for Social History 62(1) (2017), 1-35.

Knotter, Ad, 'Labour Migrants and Cross-Border Commuters: Comparative Perspectives on Mining Labour Markets in the Belgian-Dutch-German Borderland in the Twentieth Century', in Westermann (ed.), Montanregion als Sozialregion, 125-150.

Knotter, Ad, 'Land der vielen Grenzen. Territorialität und Textilindustrie zwischen Maas und Rhein im 18. und Anfang des 19. Jahrhunderts', Rhein-Maas. Studien zur Geschichte, Sprache und Kultur 4 (2013), 112-140.

Knotter, Ad, 'Land van heel veel grenzen. Territorialiteit en textielindustrie tussen Maas en Rijn in de achttiende en het begin van de negentiende eeuw', in Berkvens, et al. (eds), Limburg. Een geschiedenis, II, 325-347.

Knotter, Ad (ed.), Mijnwerkers in Limburg. Een sociale geschiedenis. Nijmegen, 2012.

Knotter, Ad, 'Les ouvriers du cigare à l'échelle transnationale. Marchés du travail transfrontaliers, grèves et solidarités à l'époque de la Première Internationale (1864-1873)', Cahiers Jaurès 2015-2016 (2015) [1914: L'Internationale et les internationalismes face à la guerre II], 35-52.

Knotter, Ad, 'Pays sans frontière? Territorialité, industrie textile et marché du travail entre Aix-la-Chapelle, Liège et Maastricht au dix-huitième siècle', in Berger, et al. (eds), Industries, territoires et cultures en Europe, 189-198.

Knotter, Ad, 'Trade Unions and Workplace Organization. Regulating Labour Markets in the Belgian and American Flat Glass Industry and in the Amsterdam Diamond Industry (c. 1880-1940)', Labor History 57 (2016), 415-438.

Knotter, Ad, 'Transnational Cigar-Makers: Cross-Border Labour Markets, Strikes, and Solidarity at the Time of the First International (1864-1873)', International Review of Social History 59(3) (2014), 409-422.

Knotter, Ad, "Van "defensieve standsreflex" tot "verkoopkartel van arbeidskracht". Twee fasen in de ontwikkeling van de Amsterdamse arbeidersvakbeweging (ca. 1870-ca. 1895)', Tijdschrift voor Sociale Geschiedenis 19 (1993), 68-93.

Knotter, Ad, B. Altena, and D. Damsma (eds), Labour, Social Policy, and the Welfare State: Papers Presented to the Ninth British-Dutch Conference on Labour History, Bergen 1994. Amsterdam, 1997 .

Knotter, Ad, and Jan Luiten van Zanden, 'Immigratie en arbeidsmarkt in Amsterdam in de 17e eeuw', Tijdschrift voor Sociale Geschiedenis 13 (1987), 403-431.

Knudsen, Knud, 'The Strike History of the First International', in Van Holthoon and Van der Linden (eds), Internationalism in the Labour Movement, 304-322.

Koch, Max, 'Employment Standards in Transition: From Fordism to Finance-Driven Capitalism', in idem and Fitz (eds), Non-Standard Employment in Europe, 29-45.

Koch, Max, Roads to Post-Fordism: Labour Markets and Social Stuctures in Europe. Abingdon, 2006. 
Koch, Max, and Martin Fitz (eds), Non-Standard Employment in Europe. Paradigms, Prevalence and Policy Response. Basingstoke, 2013.

Koch-Baumgarten, Sigrid, Gewerkschaftsinternationalismus und die Herausforderung der Globalisierung. Das Beispiel der Internationalen Transportarbeiterföderation (ITF). Frankfurt am Main, 1995.

Kocka, Jürgen, 'Craft Traditions and the Labour Movement in Nineteenth-Century Germany', in Thane, Crossick, and Floud (eds), The Power of the Past, 95-117.

Kocka, Jürgen (ed.), Work in a Modern Society. The German Historical Experience in Comparative Perspective. New York and Oxford, 2010.

Koppenjan, Jan, 'Interconfessionalisme en verzuiling in Limburg 1900-1920' (unpublished MA thesis, Erasmus University, Rotterdam, 1984).

Korres, Achim, 'Historische interacties in de Euregio Maas-Rijn. Migratiestromen in een grensgebied', Studies over de sociaal-economische geschiedenis van Limburg/Jaarboekvan het Sociaal Historisch Centrum voor Limburg 47 (2002), 7-26.

Kreukels, Loek, Mijnarbeid. Volgzaamheid en strijdbaarheid. Geschiedenis van de arbeidsverhoudingen in de Nederlandse steenkolenmijnen, 1900-1940. Assen and Maastricht, 1986.

Kuijpers, Erika, Migrantenstad. Immigratie en sociale verhoudingen in 17e-eeuws Amsterdam. Hilversum, 2005.

Kurgan-Van Hentenryk, G., and J. Stengers (eds), L'innovation technologique. Facteur de changement (XIXe-XXe siècles). Brussels, 1986.

Laar, Albert Van, Geschiedenis van de Arbeidersbeweging te Antwerpen en omliggende. Antwerp, 1926.

Laar, Albert Van, 'Uit de eerste vakbeweging van Antwerpen', De Socialistische Gids 13 (1928), 737-747.

Lahme, Hans-Norbert, 'Der Deutsche Social-Demokratische Arbeiterverein in Kopenhagen und die dänische Arbeiterbewegung', International Review of Social History 21(2) (1976), 240-255.

Lahme, Hans-Norbert, 'Zur Vorgeschichte der dänischen IAA-Sektion', International Review of Social History 19(1) (1974), 54-72.

Lambert, Rob, and Andrew Herod (eds), Neoliberal Capitalism and Precarious Work: Ethnographies of Accomodation and Resistance. Cheltenham, 2016.

Langeweg, Serge, Mijnbouw en arbeidsmarkt in Nederlands-Limburg. Herkomst, werving, mobiliteit en binding van mijnwerkers tussen 1900 en 1965. Hilversum, 2011.

Laslett, John H. M., 'Samuel Gompers and the Rise of American Business Unionism', in Dubofsky and Van Tine (eds), Labor Leaders in America, 62-88.

Laufenberg, Heinrich, Geschichte der Arbeiterbewegung in Hamburg, Altona und Umgegend, 2 vols. Hamburg, 1911-1931.

Lebrun, Pierre, L'industrie de la laine à Verviers pendant le XVIIIe et le début du XIXe siècle. Liège, 1948.

Leeson, R. (ed.), Hayek: A Collaborative Biography, Part V. Manchester, 2014.

Leeson, R., Travelling Brothers: The Six Centuries'Road from Craft Fellowship to Trade Unionism. London, 1980.

Lefèbvre, Philippe, L'invention de la Grande Entreprise. Travail, hiérarchie, marché. France, fin XVIIIe-début XXe siècle. Paris, 2003.

Lefèbvre, Virgile, La verrerie à Vitres et les verriers de Belgique depuis le XVe siècle. Paris and Brussels, 1938.

Leikin, Steve, The Practical Utopians: American Workers and the Cooperative Movement in the Gilded Age. Detroit, 2005. 
Lejeune, Jean, Pays sans frontière. Aix-la Chapelle, Liège, Maastricht: étude sur leur évolution historique. Brussels, 1958.

Lenger, Friedrich, 'Beyond Exceptionalism: Notes on the Artisanal Phase of the Labour Movement in France, England, Germany and the United States', International Review of Social History 36(1) (1991), 1-23.

Lenger, Friedrich, 'Die handwerkliche Phase der Arbeiterbewegung in England, Frankreich, Deutschland und den USA. Plädoyer für einen Vergleich', Geschichte und Gesellschaft 13 (1987), 232-243.

Lerner, Stephen, 'Global Corporations, Global Unions', Contexts 6(3) (2007), 16-22 [repr. in Goodwin and Jasper (eds), The Social Movements Reader, 364-371].

Lerner, Stephen, 'Global Unions: A Solution to Labor's Worldwide Decline', New Labor Forum 16(1) (2007), 22-37.

Lerner, Stephen, 'Let's Get Moving: Labor's Survival Depends on Organizing Industry-Wide for Justice and Power', Labor Research Review 1(18) (1991), 1-15.

Lerner, Stephen, Jill Hurst, and Glenn Adler, 'Fighting and Winning in the Outsourced Economy: Justice for Janitors at the University of Miami', in Bernhardt, et al. (eds), The Gloves-off Economy, 243-267.

Liedtke, Rainer, Jewish Welfare in Hamburg and Manchester c. 1850-1914. Oxford, 1998.

Linden, Marcel van der, 'The National Integration of the European Working Classes (1871-1914): Exploring the Causal Configuration', International Review of Social History 33(3) (1988), 285-311 [repr. in idem, Transnational Labour History, 23-47].

Linden, Marcel van der, 'Pourquoi le déclin de la Première Internationale était-il inéluctable?', Cahiers d'histoire de l'Institut de recherches marxistes 37 (1989), 125-133.

Linden, Marcel van der, 'The Rise and Fall of the First International: An Interpretation', in Van Holthoon and Van der Linden (eds), Internationalism in the Labour Movement, 323-335.

Linden, Marcel van der, Transnational Labour History: Explorations. Aldershot, 2003.

Linden, Marcel van der, 'Transnationale Arbeitergeschichte', in Budde, et al. (eds), Transnationale Geschichte, 265-274.

Linden, Marcel van der, Workers of the World: Essays toward a Global Labour History. Leiden, etc., 2008.

Lis, C., and H. Soly, “An Irresistible Phalanx”: Journeymen Associations in Western Europe, 1300-1800', in idem and J. Lucassen (eds), 'Before the Unions: Wage Earners and Collective Action in Europe, 1300-1850', International Review of Social History 39 (1994) Suppl. 2, 11-52.

Littler, Craig, The Development of the Labour Process in Capitalist Societies: A Comparative Study of the Transformation of Work Organization in Britain, Japan and the USA. London, 1982.

Llewellyn Smith, H., 'Influx of Population', in Booth (ed.), Life and Labour of the People of London, vol. VIII, 501-561.

Logue, John, Toward a Theory of Trade Union Internationalism. Gothenburg, 1980.

Lucassen, Leo, 'The Great War and the Origins of Migration Control in Western Europe and the United States (1880-1920)', in Böckler, et al. (eds), Regulation of Migration, 45-72.

Lucassen, Leo, and Boudien de Vries, 'The Rise and Fall of a West European Textile-Worker Migration System: Leiden, 1586-1700', in Gayot and Minard (eds), Les ouvriers qualifiés de l'industrie, 23-42.

Luciani, J., 'Logiques du placement ouvrier au XIXe siècle et construction du marché du travail', Sociétés Contemporaines 3 (1990), 5-18.

Luff, Jennifer, 'Justice for Janitors', in Arnesen (ed.), Encyclopedia of US Labor and Working-Class History, I, 729-731. 
Lyddon, Dave, 'From Unemployment Benefit to Redundancy Pay. Trade Unions, the State, and Unemployment in the British Car Industry, 1911-1965', in Knotter, Altena, and Damsma (eds), Labour, Social Policy, and the Welfare State, 99-110.

Lyddon, David, 'History and Industrial Relations', in Ackers and Wilkinson (eds), Understanding Work and Employment, 89-118.

Lyddon, Dave, 'Industrial-Relations Theory and Labor History', International Labor and Working Class History 46 (1994), 122-141.

Maatta, Stephanie L., 'El Lector's Canon: Social Dynamics of Reading from Havana to Tampa' (http://conference.ifla.org/past/ifla77/81-maatta-en.pdf).

Machtan, Lothar, Streiks und Aussperrungen im Deutschen Kaiserreich. Eine sozialgeschichtliche Dokumentation für die Jahre 1871 bis 1875 . Berlin, 1984.

Maier, Charles, 'Consigning the Twentieth Century to History: Alternative Narratives for the Modern Era', American Historical Review 105 (2000), 807-831.

Maier, Charles, 'Transformations of Territoriality 1600-2000', in Budde, et al. (eds), Transnationale Geschichte, 23-55.

Maitte, Corine, Philippe Minard, and Matthieu de Oliveira (eds), La gloire de l'industrie XVIIe-XIXe siècle. Faire de l'histoire avec Gérard Gayot. Rennes, 2012.

Mangold, Josef, 'Aufstieg und Niedergang der Tuchindustrie in Monschau im 18. und 19. Jahrhundert', in Stiftung Scheibler-Museum, Das Rote Haus, 97-115.

Mansfield, M., 'Flying to the Moon: Reconsidering the British Labour Exchange System in the Early Twentieth Century', Labour History Review 66 (2001), 24-40.

Mansfield, M., 'Labour Exchanges and the Labour Reserve in Turn of the Century Social Reform', Journal of Social Policy 21 (1992), 455.

Mansfield, M., R. Salais, and N. Whiteside, Aux sources du chômage 1880-1914. Une comparaison interdisciplinaire entre la France et la Grande-Bretagne. Paris, 1994.

Marijnissen, Lilian, 'Met één hand kun je niet klappen. Over organising binnen de vakbeweging' (MA thesis, University of Amsterdam, 2008).

Marinus, Bauke, and Bob Reinalda, 'Wertwijn, Jan Willem', in Biografisch woordenboekvan het socialisme, $\mathrm{V}, 301-304$.

Marx, Karl, Value, Price and Profit. New York, 1969; first published in German, 1898.

Mayer-Ahuja, Nicole, 'Three Worlds of Cleaning: Women's Experiences of Precarious Labor in the Public Sector, Cleaning Companies and Private Households of West Germany, 1973-1998', Journal of Women's History 16(2) (2004), 116-141.

Mayhew, Henry, London Labour and the London Poor: Cyclopaedia of the condition and earnings of those that will work, those that cannot work, and those that will not work, 4 vols. London, 1861; orig. 1849/50.

McCallum, Jamie K., Global Unions, Local Power: The New Spirit of Transnational Labor Organizing. Ithaca, NY, and London, 2013.

McClelland, Keith, and Alistair Reid, 'Wood, Iron and Steel: Technology, Labour and Trade Union Organisation in the Shipbuilding Industry, 1840-1914', in Harrison and Zeitlin (eds), Divisions of Labour, 151-184.

McIlroy, John, and Richard Crouch, 'The Turn to Transnational Labor History and the Study of Global Trade Unionism', Labor History 54 (2013), 491-511.

Meester, Jan De, 'To Kill Two Birds with One Stone: Keeping Immigrants in by Granting Free Burghership in Early Modern Antwerp', in Davids and De Munck (eds), Innovation and Creativity, 95-113. 
Mélanges d'histoire offerts à Henri Pirenne par ses anciens élèves et ses amis à l'occasion de sa quarantième année d'enseignement à l'université de Gand 1886-1926, 2 vols. Brussels, 1926.

Memorials of London and London Life in the 13th, 14th and 15th Centuries. London, 1868.

Methorst, M.H.W., 'La lutte contre le chômage aux Pays-Bas', Rapport No. 41, in Compte rendu de la Conférence Internationale du Chômage. Tome deuxième III (1re partie).

Michel, Joël, 'La Chevalerie du Travail (1890-19o6). Force ou Faiblesse du Mouvement Ouvrier Belge', Revue Belge d'Histoire Contemporaine 9 (1978), 117-164.

Milkman, Ruth, LA Story: Immigrant Workers and the Future of the US Labor Movement. New York, 2006.

Milkman, Ruth, 'Two Worlds of Unionism: Women and the New Labor Movement', in Cobble (ed.), The Sex of Work, 63-80.

Milkman, Ruth, and Ed Ott (eds), New Labor in New York: Precarious Workers and the Future of the Labor Movement. Ithaca, NY, 2014.

Milkman, Ruth, and Kim Voss, 'New Unity for Labor?', Labor: Studies in Working Class History of the Americas 2(1) (2005), 15-25.

Milkman, Ruth, and Kim Voss (eds), Rebuilding Labor: Organizing and Organizers in the New Union Movement. Ithaca, NY, and London, 2004.

Mill, John Stuart, Principles of Political Economy with Some Applications to Social Philosophy. London, new edition, 1909.

Mill, John Stuart, 'Thornton on Labour and its Claims', Fortnightly Review 5 (May 1869), 505-518.

Mines, Richard, and Jeffrey Avina, 'Immigrants and Labor Standards: The Case of California Janitors', in Bustamente, Reynolds, and Hinojosa Ojeda (eds), US-Mexico Relations, 429-448.

Minke, Alfred, 'Arbeiterunruhen und Arbeitersolidarität in Eupen zur französischen Zeit', Geschichtliches Eupen 20 (1986), 103-132.

Minke, Alfred, 'Die politische Verhältnisse zwischen Maas und Rhein von 1780 bis 1820', in Schmidt, et al., Eine Gesellschaft von Migranten, 26-40.

Mirowski, Philip, and Dieter Plehwe (eds), The Road from Mont Pèlerin: The Making of the Neoliberal Thought Collective. Cambridge, MA, and London, 2009.

Moberg, David, 'Translating Solidarity: As SEIU Organizes on a Global Scale, It Must Adapt its Approach to Accommodate Cultural Differences', American Prospect 21(10) (2010), A12.

Möller, Hans-Kai, 'Zigarrenheimarbeiter in Altona-Ottensen 1865-1914. Zu den Auswirkungen der Arbeits-, Wohn- und Lebensverhältnisse auf ihre politische Orientierung', in Paetau and Rüdel (eds), Arbeiter und Arbeiterbewegung, 51-96.

Mommsen, Wolfgang J., and Hans-Gerhard Husung (eds), The Development of Trade Unionism in Great Britain and Germany, 1880-1914. London, 1985.

Montgomery, David, Beyond Equality: Labor and the Radical Republicans 1862-1872. New York, 1981.

Montgomery, David, The Fall of the House of Labor: The Workplace, the State, and American Labor Activism, 1865-1925. Cambridge, 1987.

Moody, Kim, US Labor in Trouble and Transition: The Failure of Reform from Above, the Promise of Revival from Below. New York, 2007.

Mooij, Joke, 'Guldens versus franken en thalers: de geldcirculatie in Limburg tussen 1839-1914', Studies over de sociaal-economische geschiedenis van Limburg/Jaarboek van het Sociaal Historisch Centrum voor Limburg 49 (2004), 7-29.

Moss, Bernard H., The Origins of the French Labor Movement: The Socialism of the Skilled Workers, 1830-1914. Berkeley, CA, 1976.

Moss, Bernhard H., 'Parisian Producers' Associations (1830-51): The Socialism of Skilled Workers', in Price (ed.), Revolution and Reaction, 73-86. 
Moss, Bernard H., 'Producers' Associations and the Origins of French Socialism: Ideology from below', Journal of Modern History 48 (1976), 69-89.

Most, O., 'Die Handhabung der Kontrolle in den Arbeitslosenversicherungseinrichtungen Deutschlands', Rapport No. 4, in Compte rendu de la Conférence Internationale du Chômage. Tome deuxième III (rre partie).

Müller-Jentsch, Walther, Soziologie der Industriellen Beziehungen. Eine Einführung. Frankfurt am Main, 1986.

Munar Suard, Lorenzo, and Guy Lebeer, 'Nature et contenus de la relation de sous-traitance dans le secteur du nettoyage', Travail Emploi Formation 6 (2006), 6-31.

Musso, S., La regole e l'elusione. Il governo del mercato del lavoro nell'industrializzazione italiana (1880-2003). Turin, 2004.

Nas, Dik, Koerier van een nieuwe tijd. Hendrik Gerhard en de ontwikkeling van de internationale arbeidersbeweging. Amsterdam and The Hague, 2001.

Nelson, Daniel, Managers and Workers. Origins of the New Factory System in the United States 1880-1920. Madison, WI, 1975 .

Nettlau, Max, 'Ein verschollener Nachklang der Internationale. The International Labour Union', Archiv für die Geschichte des Sozialismus und der Arbeiterbewegung 9 (1921), 134-145.

Neu, P., 'Die Gesindemärkte der Südeifel', Rheinische Vierteljahrsblätter 32 (1968), 498-522.

Nizzoli, Cristina, C'est du propre! Syndicalisme et travailleurs du 'bas de l'échelle' (Marseille et Bologne). Paris, 2016.

Noiriel, Gérard, Les ouvriers dans la société française, XIXe-XXe siècle. Paris, 1986.

Noiriel, Gérard, La tyrannie du national. Le droit d'asyle en Europe 1793-1993. Paris, 1991.

Notices historiques sur le pays de Liège réceuillies par G. N[autet], troisième et dernière série. Verviers, 1859 .

Olders, Diederik and Sjaak van der Velden, Respect! De staking van de schoonmakers in 2010. Rotterdam, 2011.

Olson, Mancur, The Rise and Decline of Nations: Economic Growth, Stagflation, and Social Rigidities. New Haven, CT, 1982.

Onderzoek naar de geschiedenis en werkzaamheden der Vakverenigingen [Bijdragen tot de Statistiek van Nederland IV]. The Hague, 1896.

'Organise Local, Strike Global: Valery Alzaga Talks to Rodrigo Nunes about the Service Employees International Union's (SEIU) Global Organising Approach', Turbulence: Ideas for a Movement 1 (2007).

Ormestad, M., 'Le contrôle des chomeurs en Norvège d'après la Loi du 12 Juin 1906', Rapport No. 40, in Compte rendu de la Conférence Internationale du Chômage. Tome deuxième III (1re partie).

Ormrod, David, The Rise of Commercial Empires: England and the Netherlands in the Age of Mercantilism, 1650-1770. Cambridge, 2003.

Oudenampsen, Merijn, 'Precariousness in the Cleaning Business: Cleaners as the Vanguard of a New Trade Union Revival', Open! Platform for Art, Culture and the Public Domain (2009) (https://www.onlineopen.org/precariousness-in-the-cleaning-business).

Paauwe, Dylan, 'Tegenkracht. Een onderzoek naar de kwalitatieve aspecten van het organisingmodel in de schoonmakersstaking van 2012' (BA thesis, University of Amsterdam, 2012).

Paetau, Rainer, and Holger Rüdel (eds), Arbeiter und Arbeiterbewegung in Schleswig-Holstein im 19. und 20. Jahrhundert. Neumünster, 1987. 
Pai, Hsiao-Hung, 'The Invisibles: Migrant Cleaners at Canary Wharf', Feminist Review 78 (2004), 164-174.

Parfitt, Steven, 'Brotherhood from a Distance: Americanization and the Internationalism of the Knights of Labor', International Review of Social History 58(3) (2013), 463-491.

Parfitt, Steven, 'The First-and-a-half International: The Knights of Labor and the History of International Labour Organization in the Nineteenth Century', Labour History Review 80 (2015), 135-167.

Pasture, Patrick, 'Anti-internationalisme en anti-socialisme in de christelijke arbeidersbeweging. Vlaanderen in internationaal perspectief', Brood \& Rozen. Tijdschrift voor de Geschiedenis van Sociale Bewegingen 2 (1997), 25-39.

Pasture, Patrick, Histoire du syndicalisme chrétien international. La difficile recherche d'une troisième voie. Paris, 1999.

Pasture, Patrick, 'Introduction: Between Cross and Class. Christian Labour in Europe 1840-2000', in Heerma van Voss, Pasture, and De Maeyer (eds), Between Cross and Class, 9-48.

Pasture, Patrick, and Johan Verberckmoes (eds), Working-Class Internationalism and the Appeal of National Identity: Historical Debates and Current Perspectives on Western Europe. Oxford and New York, 1998.

Peet, Jan, and Willibrord Rutten, Oranje Nassau Mijnen. Een pionier in de Nederlandse steenkolenmijnbouw 1893-1974. Zwolle, 2010.

Pelling, Henry, 'The Knights of Labor in Britain, 1880-1901', Economic History Review, new series 9 (1956), 313-331.

Perrier, Hubert, 'De l'Internationale à "syndicalisme pur et simple”. L'influence de l'AIT sur le mouvement ouvrier aux Etats-Unis', Cahiers d'histoire de l'Institut de recherches marxistes 37 (1989), 107-123.

Perrier, Hubert, 'Idées et movement socialistes aux États-Unis 1864-1890, Tome I, La Première Internationale' (thèse de Doctorat d'État). Paris, 1984.

Perry, Jos, Roomsche kininie tegen roode koorts. Arbeidersbeweging en katholieke kerk in Maastricht 1880-1920. Amsterdam, 1983.

Phelan, Craig (ed.), The Future of Organised Labour: Global Perspectives. Oxford, etc., 2006.

Phelan, Craig (ed.), Trade Union Revitalisation: Trends and Prospects in 34 Countries. Oxford, etc., 2007.

Phelan, Craig (ed.), Trade Unionism since 1945: Towards a World History. Oxford, etc., 2009.

Pierenkemper, T., and R. Tilly (eds), Historische Arbeitsmarktforschung. Entstehung, Entwicklung und Probleme der Vermarktung von Arbeitskraft [Kritische Studien zur Geschichtswissenschaft 49]. Göttingen, 1982 .

Pigenet, Michel, Patrick Pasture, and Jean-Louis Robert (eds), L'apogée des syndicalismes en Europe occidentale 1960-1985. Paris, 2005.

Le placement d'utilité publique. La question du placement en Belgique par M. Louis Varlez. N.d. n.p.

Polanyi, Karl, The Great Transformation: The Political and Economic Origin of Our Time. Boston, 1944 .

Pollard, Sidney, The Genesis of Modern Management: A Study of the Industrial Revolution in Great Britain. London, 1965 .

Pollins, Harold, Economic History of the Jews in England. East Brunswick, NJ, 1982.

Posthumus. N.W. (ed.), Bescheiden betreffende de provinciale organisatie der Hollandsche lakenbereiders (de zgn. Droogscheerderssynode). Amsterdam, 1917.

Posthumus, N.W., 'De industrieele concurrentie tusschen Noord- en Zuid-Nederlandsche nijverheidscentra in de XVIIe en XVIIIe eeuw', in Mélanges d'histoire offerts à Henri Pirenne, Tome premier, 369-378. 
Price, Roger (ed.), Revolution and Reaction: 1848 and the Second French Republic. London, 1975.

Prothero, I.J., Artisans and Politics in Early Nineteenth-Century London:John Gast and his Times. Folkestone, 1979.

Prothero, Iorwerth, Radical Artisans in England and France, 1830-1870. Cambridge, 1997.

Protokoll der Verhandlungen des 2. Kongresses der Freien Gewerkschaften 1896, Berlin vom 4.-8. mai 1896 . Hamburg, 1896.

Rancière, Jacques, 'The Myth of the Artisan: Critical Reflections on a Category of Social History', International Labor and Working-Class History 24 (1983), 1-16 [repr. in Kaplan and Koepp (eds), Work in France, 317-334].

Randall, Adrian, Before the Luddites: Custom, Community and Machinery in the English Woollen Industry, 1776-1809. Cambridge, 1991.

Randall, Adrian, 'The Shearmen and the Wiltshire Outrages of 1802: Trade Unionism and Industrial Violence', Social History 7 (1982), 283-304.

Rapport aangaande de Werkstaking der Timmerlieden gedurende het jaar 1894. Amsterdam, 1895. Recio, Albert, and Alejandro Godino, 'Invisible Workers: Quality of Employment in the Cleaning Sector in Spain', https://www.researchgate.net/publication/278390169_Invisible_Workers_Quality_of_employment_in_the_cleaning_sector_in_Spain.

Rees, Gareth, and Sarah Fielder, 'The Services Economy, Subcontracting and the New Employment Relations: Contract Catering and Cleaning', Work, Employment and Society 6(3) (1992), 347-368.

Regini, Marino (ed.), The Future of Labour Movements. London, 1992.

Reid, Donald, The Miners of Decazeville: A Genealogy of Deindustrialization. Cambridge, MA, 1985.

Reith, Reinhold, 'Arbeitsmarkt und Gesellenstreik vom 15. bis ins 19. Jahrhundert', in Westermann and Westermann (eds), Streik im Revier, 177-219.

Reith, Reinhold, Lohn und Leistung. Lohnforme im Gewerbe 1450-19oo. Stuttgart, 1999.

Reith, Reinhold, Andreas Grießinger and Petra Eggers, Streikbewegungen deutscher Handwerksgesellen im 18. Jahrhundert. Materialen zur Sozial- und Wirtschaftsgeschichte des städtischen Handwerks 1700-1806. Göttingen, 1992.

Ridder, Widukind De, 'Loonsystemen, arbeidsorganisatie en arbeidsverhoudingen in de Belgische glas- en textielnijverheid, 1886-1914' (unpublished doctoral thesis, Brussels University, 2010).

Riley, H.T. (ed.), 'Memorials: 1350', in Memorials of London, 247-265.

Risch, B., 'Gewerkschaftseigene Arbeitslosenversicherung vor 1914', Weltwirtschaftliches Archiv 117 (1981), 518.

Robert, Jean-Louis, Friedhelm Boll, and Antoine Prost (eds), L'invention des syndicalismes. Le syndicalisme en Europe occidentale à la fin du XIXe siècle. Paris, 1997.

Robertson, Paul L., 'Demarcation Disputes in British Shipbuilding before 1914', International Review of Social History 20(2) (1975), 220-235.

Rößler, Horst, “'Amerika, du hast es besser”. Zigarrenarbeiter aus dem Vierstädtegebiet wandern über den Atlantik, 1868-1886', Demokratische Geschichte.Jahrbuch zur Arbeiterbewegung und Demokratie in Schleswig-Holstein 4 (1989), 87-119.

Rößler, Horst, 'Traveling Workers and the German Labor Movement', in Hoerder and Nagler (eds), People in Transit, 127-145.

Rudé, George, The Crowd in History: A Study of Popular Disturbances in France and England 1730-1848. London, 1964.

Rudischhauser, Sabine, Geregelte Verhältnisse. Eine Geschichte des Tarifvertragsrechts in Deutschland und Frankreich (1890-1918/19). Cologne, etc., 2017. 
Rudischhauser, S., and B. Zimmermann, “Öffentliche Arbeitsvermittlung” (1890-1914). Kategorien der Invention der öffentlichen Hand - Reflexionen zu einem Vergleich', Comparativ - Zeitschrift für Globalgeschichte und vergleichende Gesellschaftsforschung 5 (1995), 93-120.

Rudy, Preston, “Justice for Janitors", Not "Compensation for Custodians": The Political Context and Organizing in San Jose and Sacramento', in Milkman and Voss (eds), Rebuilding Labor, 133-149.

Rule, John (ed.), British Trade Unionism 1750-1850: The Formative Years. London and New York, 1988. Rule, John, 'The Formative Years of British Trade Unionism: An Overview', in idem (ed.), British Trade Unionism, 1-28.

Rule, John, 'The Property of Skill in the Period of Manufacture', in Joyce (ed.), The Historical Meanings of Work, 99-118.

Rule, John, 'Review Essay: Proto-Unionism?', Historical Studies in Industrial Relations 2 (1996), 139-152.

Rüter, A.J.C., De spoorwegstakingen van 1903. Een spiegel der arbeidersbeweging in Nederland. Leiden, 1935 .

Rutten, Willibrord, 'Het thuisfront van de mijnwerker', in Knotter (ed.), Mijnwerkers in Limburg, 388-424.

Ryan, Shaun, and Andrew Herod, 'Restructuring the Architecture of State Regulation in the Australian and Aotearoa/New Zealand Cleaning Industries and the Growth of Precarious Employment', Antipode: A Radical Journal of Geography 38(3) (2006), 486-507.

Sassen, Saskia, The Global City: New York, London, Tokyo. Princeton, NJ, 1991.

Scandella, Fabienne, 'Tel un phénix renaissant des poussières. Renouveau syndical dans le secteur du nettoyage: analyse de la campagne londonienne "Justice for cleaners", in Béroud and Bouffartigue (eds), Quand le travail se précarise, 117-131.

Scandella, Fabiene, 'Travail invisible dans un secteur de relégation. La double condition des nettoyeurs de bureaux', Les Mondes du Travail 7 (2009), 75-86.

Scheffer, H.J., 'Rot, Adriaan', Biografisch Woordenboek van het Socialisme 3, 177-178.

Schmalz, Stefan, and Klaus Dörre (eds), Comeback der Gewerkschaften? Machtsressourcen, innovative Praktiken, internationale Perspektiven. Frankfurt and New York, 2013.

Schmidt, Martin, 'Burtscheid um 1800. Migrationserfahrung und Integration in einem Manufakturort', in idem, et al., Eine Gesellschaft von Migranten, 67-89.

Schmidt, Martin, et al., Eine Gesellschaft von Migranten. Kleinräumige Wanderung und Integration von Textilarbeitern im belgisch-niederländisch-deutschen Grenzraum zu Beginn des 19. Jahrhunderts. Bielefeld, 2008.

Schmuhl, H.-W., Arbeitsmarktpolitik und Arbeitsverwaltung in Deutschland 1871-2002 [Beiträge zur Arbeitsmarkt- und Berufsforschung 270]. Nuremberg, 2003.

Schneider, Dorothy, Trade Unions and Community: The German Working Class in New York City, 1870-19oo. Urbana, IL, 1994.

Schneider, Michael, Die Christlichen Gewerkschaften 1894-1933. Bonn, 1982.

Schnock, H., 'Über gewerbliche Verhältnisse in Burtscheid', Aus Aachens Vorzeit. Mitteilungen des Vereins für Kunde der Aachener Vorzeit 18 (1905), 34-55.

Scholliers, E., 'Vrije en onvrije arbeiders voornamelijk te Antwerpen in de 16e eeuw', Bijdragen voor de Geschiedenis der Nederlanden 11 (1956), 309-321.

Schönhoven, Klaus, and Bernd Braun (eds), Generationen in der Arbeiterbewegung. München, 2005. Schöttler, P., Die Entstehung der 'Bourses du Travail'. Sozialpolitik und französischer Syndikalismus am Ende des 19. Jahrhunderts [Campus Forschung 255]. Frankfurt am Main and New York, 1982. 
Schrage, P. and E. Nijhof, 'Een lange sisser en een late knal? De ontwikkeling van de Nederlandse werkloosheidsverzekering in Westeuropees perspectief: een terreinverkenning', in Blockmans and Van der Valk (eds), Van particuliere naar openbare zorg, en terug?, 31-52.

Schreuer, François, 'Qu'est-ce-que le précariat?', Politique. Revue de débats 46 (2006) [Thème 'Le précariat, entre contrainte et liberté'].

Schröder, R., 'Arbeitslosenfürsorge und Arbeitsvermittlung im Zeitalter der Aufklärung', in Benöhr (ed.), Arbeitsvermittlung und Arbeitslosenversorgung, 7-76.

Schröder, Wilhelm Heinz, Arbeitergeschichte und Arbeiterbewegung. Industriearbeit und Organisationsverhalten im 19. und frühen 20. Jahrhundert. Frankfurt am Main, etc., 1978.

Schröder, Wilhelm Heinz, 'Arbeit und Organisationsverhalten der Zigarrenarbeiter in Deutschland im 19. und frühen 20. Jahrhundert. Ein Beitrag zur Erklärung der Führungsrolleder Zigarrenarbeiter in der frühen politischen Arbeiterbewegung', Historical Research, Supplement, 23 (2011), 195-251.

Schrover, Marlou, Erik Nijhof and Peter Kruisinga, 'Marx, markt, macht. Van Tijns analyseschema ter verklaring van het success of falen van vakbonden', in De Vries, et al. (eds), De Kracht der Zwakken, 193-246.

Schulte Beerbühl, M., Vom Gesellenverein zur Gewerkschaft. Entwicklung, Struktur und Politik der Londoner Gesellenorganisation 1550-1825 [Göttinger Beiträge zur Wirtschafts-und Sozialgeschichte 16]. Göttingen, 1991.

Scott, Joan Wallach, The Glassworkers of Carmaux: French Craftsmen and Political Action in a Nineteenth-Century City. Cambridge, MA, 1974.

Sekirnjak, K., Damals und heute. Kurzgefaßte Darstellung des Entwicklungsganges des Vereins für alle in der Hut-und Filzwaren-Industrie beschäftigten Arbeiter und Arbeiterinnen Niederösterreich: aus Anlass des dreissigjährigen Gründungsfestes. Vienna, 1904.

Sennett, Richard, The Corrosion of Character: The Personal Consequences of Work in the New Capitalism. New York and London, 1998.

Siddle, D. (ed.), Migration, Mobility and Modernity. Liverpool, 2000.

Silver, Beverly, Forces of Labor: Workers' Movements and Globalization since 1870. Cambridge, 2003.

Simon, Hartmut, Die Internationale Transportarbeiter-Föderation. Möglichkeiten und Grenzen internationaler Gewerkschaftsarbeit vor dem Ersten Weltkrieg. Essen, 1993.

Skrabec, Quentin, Michael Owens and the Glass Industry. Gretna, FL, 2007.

Slooten, Piet van, and Anna Wits, “Mijn beroep is timmerman". Het timmervak en de organisatie(s) van timmerlieden, ca.1865-ca.1893' (unpublished MA thesis, VU University, Amsterdam, 1981).

Sluyterman, Keetie E., Ondernemen in sigaren. Analyse van bedrijfsbeleid in vijf sigarenfabrieken in de perioden 1856-1865 en 1925-1934. Tilburg, 1983.

Sman, Marie Christine van der, 'Baye, Hermanus Franciscus', in Biografisch Woordenboek van het Socialisme 6, 23-26.

Smelser, Neil, and Richard Swedberg (eds), The Handbook of Economic Sociology. Princeton, NJ, 2005 .

Smethurst, John B., and Peter Carter (eds), Historical Directory of Trade Unions. Volume 6. Farnham, 2009.

Soerensen, T., 'La question du chômage au Danemark', Rapport No. 12, in Compte rendu de la Conférence Internationale du Chômage. Tome deuxième III (1re partie).

Soni-Sinha, Urvashi and Charlotte A.B. Yates, "Dirty Work”? Gender, Race and the Union in Industrial Cleaning', Gender, Work and Organization 20(6) (2013), 737-751.

Sørensen, Jan Ingemann, 'De Danske socialister og Første Internationale (1865-april 1871)', Arbejderhistorie 14(1) (2008), 37-55. 
Soskice, David, 'Divergent Production Regimes: Coordinated and Uncoordinated Market Economies in the 1980 s and 1990s', in Kitschelt, et al. (eds), Continuity and Change in Contemporary Capitalism, 101-134.

Southall, H.R., 'The Tramping Artisan Revisits: Labour Mobility and Economic Distress in Early Victorian England', Economic History Review 44 (1991), 272-296.

Sprenger, Jeroen J.C., 'Verdorst, Pieter Marinus', in Biografisch Woordenboek van het Socialisme 4, 204-211.

Springer, Simon, Kean Birch, and Julie MacLeavy (eds), The Handbook of Neoliberalism. Abingdon and New York, 2016.

Standing, Guy, The Precariat: The New Dangerous Class. London, 2011.

Standing, Guy, A Precariat Charter: From Denizens to Citizens. London, 2014.

Standing, Guy, Work after Globalization: Building Occupational Citizenship. Cheltenham, 2009.

Stanford, J., and L. Vosko (eds), Challenging the Market: The Struggle to Regulate Work and Income. Montreal, 2004.

Statistisches Departement im k. k. Handelsministerium (ed.), Die Arbeitsvermittlung in Österreich. Verfasst und herausgegeben vom statistischen Departement im k.k. Handelsministerium. Vienna, 1898.

Stedman Jones, Gareth, Karl Marx: Greatness and Illusion. London, 2016.

Steidl, A., et al. (eds), Übergänge und Schnittmengen. Arbeit, Migration, Bevölkerung und Wissenschaftsgeschichte in Diskussion. Vienna, Cologne, and Weimar, 2008.

Stein, Axel, ,Die Schriften Fanny Imles (1878/1965) zu den industriellen Beziehungen des beginnenden 20. Jahrhunderts', Zeitschrift für Arbeitsrecht 43 (2012), 99-140.

Steiner, Yves, 'The Neoliberals Confront the Trade Unions', in Mirowski and Plehwe (eds), The Road from Mont Pèlerin, 181-203.

Steinmetz, G., Regulating the Social: The Welfare State and Local Politics in Imperial Germany. Princeton, NJ, 1993 .

Stiftung Scheibler-Museum Rotes Haus Monschau, Das Rote Haus in Monschau. Cologne, 1994.

Stone, Katherine, 'The Origins of Job Structures in the Steel Industry', Review of Radical Political Economy 6 (1974), 115-170.

Streeck, Wolfgang, 'The Sociology of Labor Markets and Trade Unions', in Smelser and Swedberg (eds), The Handbook of Economic Sociology, 254-283.

Strikwerda, Carl, 'World War I in the History of Globalization', Historical Reflections/Réflections Historiques 43 (2017), 112-132.

Stubbs, Jean, 'El Habano: The Global Luxury Smoke' [Commodities of Empire Working Paper No. 20]. London, 2012.

Stubbs, Jean, Tobacco on the Periphery: A Case Study in Cuban Labour History, 1860-1958. Cambridge, 1985 .

Swenson, Peter A., Capitalists against Markets. The Making of Labor Markets and Welfare States in the United States and Sweden. Oxford, 2002.

Swierenga, Robert P., The Forerunners: Dutch Jewry in the North American Diaspora. Detroit, 1994. Syré, Christiane, 'Ein Wirtschaftsraum bleibt erhalten! Migration in der Textilregion AachenVerviers im späten 18. und frühen 19. Jahrhundert', in Schmidt, et al., Eine Gesellschaft von Migranten, 90-118.

Tattersall, Amanda, 'Labor-Community Coalitions, Global Union Alliances, and the Potential of SEIU's Global Partnerships', in Bronfenbrenner (ed.), Global Unions, 155-173.

Thane, Pat, Geoffrey Crossick, and Roderick Floud (eds), The Power of the Past: Essays for Eric Hobsbawm. Cambridge, 1984. 
Thijs, Alfons K.L., Van 'werkwinkel' tot 'fabriek'. De textielnijverheid te Antwerpen (Einde 15 de-begin 19de eeuw). Antwerp, 1987.

Thompson, E.P., The Making of the English Working Class. Harmondsworth, repr. 1968.

Thompson, E.P., and E. Yeo (eds), The Unknown Mayhew: Selections from the Morning Chronicle, 1849-50. Harmondsworth, 1973.

Thompson, James, 'The Reception of Lujo Brentano's Thought in Britain, 1870-1910'. Working paper, Bristol University, 2007 (http://research-information.bristol.ac.uk/files/3005621/ Brentano\%2oin\%2oBritain.pdf).

Thornley, Carole, Steve Jefferys, and Beatrice Appay (eds), Globalization and Precarious Forms of Production and Employment: Challenges for Workers and Unions. Cheltenham, 2010.

Thornton, William Thomas, On Labour, its Wrongful Claims and Rightful Dues, its Actual Present and Possible Future. London, 1869.

Thümmler, Heinzpeter, Sozialistengesetz $\S 28$. Ausweisungen und Ausgewiesene 1878-189o. Berlin, 1979.

Thurley, Keith, and Stephen Wood (eds), Industrial Relations and Management Strategy. Cambridge, 1983 .

Tijn, Theo van, 'De Algemeene Nederlandsche Diamantbewerkersbond (ANDB). Een succes en zijn verklaring', Bijdragen en Mededelingen betreffende de Geschiedenis der Nederlanden 88 (1973), 403-418.

Tijn, Theo van, 'De Amsterdamse diamanthandel en -nijverheid, 1845-1940', Holland: RegionaalHistorisch Tijdschrift 21 (1989), 248-262.

Tijn, Theo van, 'A Contribution to the Scientific Study of the History of Trade Unions', International Review of Social History 21(2) (1976), 212-239.

Tijn, Th. van, 'Geschiedenis van de Amsterdamse diamanthandel en -nijverheid, 1845-1897', Tijdschrift voor Geschiedenis 87 (1974), 16-70 and 160-210.

Tijn, Theo van, Twintig jaren Amsterdam. De maatschappelijke ontwikkeling van de hoofdstad, van de jaren ' 50 der vorige eeuw tot 1876 . Amsterdam, 1965.

Tijn, Theo van, 'Voorlopige notities over het ontstaan van het moderne klassebewustzijn in Nederland', Mededelingenblad. Orgaan van de Nederlandse Vereniging tot beoefening van de Sociale Geschiedenis 45 (1974), 33-48.

Tillman, R., and M. Cummings (eds), The Transformation of US Unions: Voices, Visions, and Strategies from the Grassroots. Boulder, CO, 1999.

Tinajero, Araceli, El Lector: A History of the Cigar Factory Reader. Austin, TX, 2010.

Todt, Elisabeth, Die gewerkschaftliche Betätigung in Deutschland von 1850 bis 1859 . Berlin, 1950.

Todt, Elisabeth, and Hans Radandt, Zur Frühgeschichte der deutschen Gewerkschaftsbewegung 1800-1849. Berlin, 1950.

Topalov, C., Naissance du chômeur 1880-1910. Paris, 1994.

Tosstorff, Reiner, The Red International of Labour Unions (RILU) 1920-1937. Leiden and Boston, 2016.

Troyer, Marianne De, Guy Lebeer, and Esteban Martinez, 'La précarité des ouvrières du nettoyage en Belgique. Des réponses collectives à la dérégulation', Travail, genre et sociétés 29(1) (2013), 87-104.

Truant, Cynthia M., 'Independent and Insolent: Journeymen and their "Rites" in the Old Regime Workplace', in Kaplan and Koepp (eds), Work in France, 131-175.

Uhen, Leo, Gruppenbewußtsein und informelle Gruppenbildung bei deutschen Arbeitern im Jahrhundert der Industrialisierung. Berlin, 1964.

Ulman, Lloyd, The Rise of the National Trade Union: The Development and Significance of Its Structure, Governing Institutions, and Economic Policies. Cambridge, MA, 1966. 
Vandaele, Kurt, and Janine Leschke, 'Following the "Organising Model" of British Unions? Organising Non-standard Workers in Germany and the Netherlands', European Trade Union Institute (ETUI), Working Paper 2010.02 (ETUI, 2010).

Vandervelde, Émile, Enquête sur les associations professionnelles d'artisans et ouvriers en Belgique, 2 vols, Brussels, 1891 .

Vanfraechem, Stephan, Een sfeer om haring te braden. Arbeidsverhoudingen in de haven van Antwerpen. Gent, 2005.

Vanthemsche, G., 'De oorsprong van de werkloosheidsverzekering in België. Vakbondskassen en gemeentelijke fondsen (1890-1914)', Tijdschrift voor Sociale Geschiedenis 11 (1985), 130-164.

Varoufakis, Yanis, Adults in the Room: My Battle with Europe's Deep Establishment. London, 2017.

Velde, C.A. van der, De ANDB. Een Overzicht van zijn Ontstaan, zijne Ontwikkeling en zijne Beteekenis. Amsterdam, 1925.

Vint, John, Capital and Wages: A Lakatosian History of the Wage Fund Doctrine. Aldershot, 1994.

Vliegen, W.H., De dageraad der volksbevrijding. Schetsen en taferelen uit de socialistische beweging in Nederland II. Amsterdam, 1905.

Vries, Boudien de, et al. (eds), De Kracht der Zwakken. Studies over arbeid en arbeidersbeweging in het verleden. Opstellen aangeboden aan Theo van Tijn bij zijn afscheid als hoogleraar Economische en Sociale Geschiedenis aan de Rijksuniversiteit Utrecht. Amsterdam, 1992.

Wadauer, S., 'Vazierende Gesellen und wandernde Arbeitslose (Österreich, ca. 1880-1938)', in Steidl, et al. (eds), Übergänge und Schnittmengen, 101-132.

Wadauer, Sigrid, Thomas Buchner, and Alexander Mejstrik (eds), The History of Labour Intermediation: Institutions and Finding Employment in the Nineteenth and Early Twentieth Centuries [International Studies in Social History Volume 26]. Oxford and New York, 2015.

Wal, F. van der, De oudste vakbond van ons land 1866.1916. Ontstaan en vijftigjarige werkzaamheid van den Algemeenen Nederl. Typografenbond. Nijmegen, 1915 .

Waldinger, Roger, et al., 'Helots No More: A Case Study of the Justice for Janitors Campaign in Los Angeles', in Bronfenbrenner, et al. (eds), Organizing to Win, 102-119.

Webb, Sidney, and Beatrice Webb, The History of Trade Unionism, 166o-1920. London, 1894/1920. Webb, Sidney, and Beatrice Webb, Industrial Democracy. London, 1897.

Welskopp, Thomas, Arbeit und Macht im Hüttenwerk. Arbeits- und Industrielle Beziehungen in der Deutschen und Amerikanischen Eisen- und Stahlindustrie von den $1860 e r$ bis zu den $1930 e r$ Jahren. Bonn, 1994.

Welskopp, Thomas, Das Banner der Brüderlichkeit. Die deutsche Sozialdemokratie vom Vormärz bis zum Sozialistengesetz. Bonn 2000.

Welskopp, Thomas, 'Le Syndicalisme dans la sidérurgie et les aciéries en Grande-Bretagne, Allemagne et États-Unis, de 1850 à 1910', in Robert, Boll, and Prost (eds), L'invention des Sydicalismes, 41-72.

Welskopp, Thomas, 'The Vision(s) of Work in the Nineteenth-Century German Labour Movement', in Kocka (ed.), Work in a Modern Society, 55-71.

Werner, Michael, and Bénédicte Zimmermann, 'Beyond Comparison: Histoire Croisée and the Challenge of Reflexivity', History and Theory 45 (2006), 30-50.

Werner, Michael, and Bénédicte Zimmermann, 'Histoire croisée. Penser l'histoire croisée entre empirie et réflexivité', Annales: Économies, Sociétés, Civilisations 58 (2003), 7-36.

Westermann, Angelika (ed.), with the help of Josef Paul, Montanregion als Sozialregion Zur gesellschaftlichen Dimension von 'Region' in der Montanwirtschaft. Husum, 2012.

Westermann, Angelika, and Ekkehard Westermann (eds), Streik im Revier. Unruhe, Protest und Ausstand vom 18. Bis 20. Jahrhundert. St. Katharinen, 2007. 
Whiteside, N., 'Définir le chômage. Traditions syndicales et politiques nationale en GrandeBretagne avant la Première Guerre mondiale', in Mansfield, Salais, and Whiteside, Aux sources du chômage, 381-411.

Whiteside, N., 'La protection du métier: l'organisation industrielle et les services des syndicats dans l'Angleterre de la fin du XIXe siècle', Cahiers d'Histoire de l'Institut de Recherches Marxistes 51 (1993), 29-51.

Whiteside, N., 'Unemployment Revisited in Comparative Perspective: Labour Market Policy in Strasbourg and Liverpool, 1890-1914', International Review of Social History 52 (1) (2007), 35-56.

Wielsma, Piet, and Heiner Becker, 'Hout, Isaac Salomon van der', in Biografisch woordenboek van het socialisme, II, 68-70.

Williams, Jane, 'Restructuring Labor's Identity: The Justice for Janitors Campaign in Washington D.C.', in Tillman and Cummings (eds), The Transformation of US Unions, 203-217.

Wills, Jane, 'Making Class Politics Possible: Organizing Contract Cleaners in London', International Journal of Urban and Regional Research 32(2) (2008), 305-323.

Wimmer, Andreas, and Nina Glick Schiller, 'Methodological Nationalism and Beyond: Nation-State Building, Migration and the Social Sciences', Global Networks 2 (2002), 301-334.

Wöltgens, Th., Mislukte doorbraak. Geschiedenis van de socialistische mijnwerkersbond 1909-1965 (unpublished MA thesis, Utrecht University, 1966).

Wouters, Hubert (ed.), Documenten betreffende de geschiedenis der arbeidersbeweging ten tijde van de Ie Internationale (1866-1880), Deel I. Louvain, 1970.

Wright, Carol D., 'Historical Sketch of the Knights of Labor', Quarterly Journal of Economics 1 (1887), 137-168.

Wright, Erik Olin, 'Is the Precariat a Class?', Global Labour Journal 7 (2) (2016), 123-135.

Wright, Erik Olin, Understanding Class. London, 2015.

Wunnava, Phanindra V. (ed.), The Changing Role of Unions: New Forms of Representation. New York, 2004.

Yearley, Clifton K., Britons in American Labor: A History of the Influence of the United Kingdom Immigrants on American Labor, 1820-1914. Baltimore, 1957.

Zimmermann, B., La constitution du chômage en Allemagne. Entre professions et territoires. Paris, 2001.

Zwahr, Hartmut, Zur Konstituierung des Proletariats als Klasse. Strukturuntersuchung über das Leipziger Proletariat während der industriellen Revolution. Munich, 1981; orig. 1978. 


\section{Index}

Aachen 21, 33, 35-38, 40-42, 44-45, 48-50, 53, 58, $60-61,65,67,197-202,215,228,272$

ABN AMRO, bank 255

Aix-la-Chapelle 36

Algemeen Mijnwerkers Fonds (AMF) 229-230, 233

Algemeen Nederlands Werklieden Verbond

(ANWV) 109-113, 115-117, 123-125, 127, 130-131

Algemeene Bond van Christelijke Mijnwerkers in Nederland (CMB) 199

Algemeene Nederlandsche Diamantbewerkers Bond (ANDB) 31, 107-108, 117, 160, 165

Algemeene Nederlandsche Mijnwerkersbond (ANMB) 199-200, 206-207, 209, 211, 213, 215, 219-223, 226-231, 233

Algemeene Nederlandsche Timmerlieden Bond (ANTB) 117, 120-121

Algemeene Nederlandsche Typographen Bond (ANTB) 108

Algemeene Nederlandse Mijnwerkersbond 'Recht en Plicht' 213, 217

Allgemeine Deutsche Schneiderverein 73

Allgemeiner Deutscher Cigarrenarbeiter-Verein 88

Alliance Cabinet Makers' Association 181

Altona 80, 90, 92

Amalgamated Association of Card and Blowing Room Operatives 183

Amalgamated Association of Cooperative Cotton Spinners 183

Amalgamated Society of Carpenters and Joiners 181

Amalgamated Society of Engineers 181,185

America see United States (USA)

America, Latin 250, 275

America, North 26, 82, 274-275

American Federation of Labor (AFL) 82, 99, 105,248

American Institutional School 17

Amstels Eendracht 108, 111, 115

Amsterdam 21-22, 27, 31, 43-48, 8o, 84-86, 88, 92, 95-98, 101, 106-108, 110, 114-118, 120-126, 128-129, 132, 138, 155-156, 158-159, 162-163, 169, 192, 207, 256, 261, 273

Amsterdam Institute for Advanced Labour Studies 244

Amsterdamsche Diamantslijperij 156

Ankoné, Joh. 213

Ansing, Willem 112

Antilles, the 257

Antwerp 21, 27-28, 43, 45-46, 80, 91, 93-94, 96, $138,159,162,165$

Assoziation der Tabakarbeiter 88

Australia 240-241, 245, 250, 252, 261, 266, 274

Austria $25,167,171-172,178$

Austrian Netherlands 36
Baden 85

Bangladesh 257

Banque de Bruxelles 153

Bavaria 176

Baye, H.F. 113

Bebel, August 80,113

Becker, Johann Philipp 80, 83

Beers, De 161

Belgium 72-73, 75-76, 83, 89-97, 99-100, 142-144, $147-148,153,155,162,164-167,171,178,186$, 190-191, 217, 245

Bensimon, Fabrice 32

Berlin 72, 80, 85, 89, 92

Bertrand, Karl 82

Beveridge, William 167, 179, 183, 186-187, 189-190, 193, 195

Birmingham 182

Bitburg 174

Bleyerheide 205

Boilermakers' Society 135

Bois-le-Duc 97

Bolte, Fred 82

Booth, Charles 86

Borcette 36

Bourdieu, Pierre 24

Bourse du Travail 167, 177

Brabant 49

Brazil 275

Bremen $78,85,87-88$

Brentano, Lujo 16

Breslau 61, 85

Briljantslijpersknechts-Vereeniging 'Streven naar Verbetering' 159

Briljantsnijdsters- en -snijders-Vereeniging 159

Britain 21, 23, 27, 40-42, 48, 65, 69, 72-74, 76, 8 , 89, 91, 95-96, 99-100, 102, 104-105, 107, 109, $133,137,142-144,167,171-172,174,177-178,184$, $187,189,193,240-241,245,266,273$

Broederband, De 114

Bruges 96

Bruhns, Julius $77-78$

Brunssum 200, 217

Brussels 36, 57, 73, 91-94, 96

Brussels Free University 31

Burnett, John 95

Burtscheid 36, 38, 40, 49, 58, 6o-61

Burtscheider Gericht 61, 68

Camere del lavoro 178

Canada 241, 245, 252

Caussin, Danton 147

Centrale Bond van Roomsch-Katholieke Mijnwerkersverenigingen 203, 222

Charleroi 27, 138, 142-143, 147, 151-152, 155, 164 Chèvremont 205 
Christelijke Mijnwerkersbond (CMB) 199-200, 202-205, 209, 211, 213, 215, 221, 223, 227-23

Christian Miners' Union 28-29, 199, 214, 224, $228,231,274$

Christliche Gewerkschaft 28

Churchill, Winston 180

Cigar Makers' International Union (CMIU) 82

Cigar Makers' Society 84

Cigar-Makers' Mutual Association 75, 86

Cigarmakers' Union No. 9089

Cincinnati 83

Clarksburg 138, 143-144, 147

Clawson, Dan 275

Clermont, Johann Arnold Von 50, 62

Coenen, Philippe 93-94

Cohn, James 75, 91-92, 94-97

Collins, Henry 74

Cologne 45, 49, 73

Concordia inter Nos 108, 112, 115, 118-119, 121, 123,125

Confraternité entre les tondeurs $52,57,59$

Congress of Industrial Organizations (CIO) 23

Conseil d'État du Roi 56

Conseil du Commerce 66

Contact-Commissie voor het Mijnbedrijf 222

Cooper, Patricia 82

Cooperative Window Glass Company 143

Copenhagen $73,83,178,192$

Cottereau, Alain 169

Courcelles 147

CSU 261

Cuba $78,84-85$

Dampremy 147, $15^{1}$

Danzig 61

De Beers Company $15^{8}$

Dekker, Rudolf $44,5^{2}$

Delwarte, Albert 143, 164

Denmark 73, 82, 178, 192-193, 240

Denny, William 136

Detroit 83

Devreese, Daisy 71

Dhondt, Jan 70-71

Diamantslijpers-Vereeniging 156

Dison 36-37

Dolan, Thomas M. 83

Domaniale Mijn 200-201, 214

Dominican Republic, the 257

Door Eendracht t'Zaamgebracht 109

Door Eendracht Verbetering 114-115, 118-121, 124-125

Door vriendschap bloeijende 88,92

Dordrecht 92

Dove, Mr. 169

Dresden 80

Dundee 182

Dunkirk 144

Düren 49,60
East Indies 85

Eccarius, Johann Georg 73

Edinburgh 72

Edmonton 252

Een Doel, een Wil 109, 111

Eensgezindheid baart vreugde 92

Eifel 174

Elsloo 210

Emma, State mine 200, 217, 219

Engelhardt, Ulrich 89

Engels, Friedrich 93, 113

England see Britain

England, West 42

Enigheden 83

Ensival 38, 53

Erlangen 190

Eschweiler Bergverein 200, 215

Eupen 36-38, 40-42, 49, 57-58, 62, 65-66

Europe 11-13, 42, 82, 84-85, 95-96, 98-100, 132, $136,142-143,168,171-174,178,186-187,193$,

199, 232, 244, 250, 266, 271-272, 274-275

Europe, Eastern 141

Europe, North-western 33, 35, 40-41, 51, 63

Europe, Western 26, 32, 35, 167, 170

European Central Bank 24

European Union 24

Eygelshoven 200

Faust, Anselm 176, 178

Fédération Nationale des Travailleurs du Verre 155

Federation of Flat Glass Workers 147

Feine Gewandschaft 54, 59, 67

Fell, Mr. 169

First International 14, 27-28, 32, 40, 66, 69-71, $80,83-84,99-101,108,110,143$

Flanders 49

FNV Bondgenoten 238-240, 250, 256-257, 262, 265,267

Fones-Wolf, Ken 32, 147

Fontaine, Marion 32

France $40,70,72-75,83,102-104,144,167$, $171-173,178,184,190-191,193,244-245$

France, Northern 21, 38

Franchimont 36

Francomont 53-54

Frankfurt (Main) 87

Freiburg 190

Friesland 117, 122, 125

Fritzsche, Friedrich Wilhelm (Fritzer) 81, 83, 88-89, 95-96

Gayot, Gérard 38, 40, 42-43, 56

Geleen 200, 210

General Tobacco Workers' Union 95

Geneva 80

Gennep, Arnold Van 173

Gerhard, Hendrik 109-110 
Germany 25, 27, 35, 40, 45, 58-59, 72-73, 75, 78, $80,83,87-91,93,97,100,102,104-105,107,144$, $167,171-172,174,178,180,187-190,193,195-196$, 199, 201-203, 205-207, 209, 216-217, 219-220, 222-228, 232-233, 241, 244-245, $25^{\circ}$

Gewerkverein christlicher Bergarbeiter Deutschlands 198-199, 213, 232

Ghana 257

Ghent 92, 96, 186, 189-191

Gilles, Edmond 151, 153

Gilly 147

Gompers, Samuel 78, 80, 84, 99, 105

Gott, Benjamin 65

Gouda 48

Great Britain see Britain

Gregoire, Amil 147

Grießinger, Andreas 63

Gruner, Erich 180

Guillaume, James 75

Haarlem 48

Haesaert, Leopold (Hasaers, Leon) 91, 96

HAGO 261

Hague, The $92,97,113,115,256$

Hamburg 27-28, 45, 72, 76, 78, 8o, 83-85, 87-9o, 92,98

Harris, José 187

Harsch, Peter 228

Haufe, Albert F. 73

Heerlen 200-202, 207, 211, 213, 217, 220-221, 223, 227,233

Heidelberg 87

Heldt, B.H. 109, 115

Hendrik, State mine 200

Hernandez, Feliciano 253

's-Hertogenbosch 85

Herzogenrath 210

Hincke, Julius 87

Hobsbawm, Eric 17, 65, 76, 104-105, 107, 134

Hodimont 36, 38, 53-54, 57, 67

Hoensbroek 200, 217, 219

Holland see Netherlands, the

Holland, North- 122, 125

Honingmann, Friedrich 200

Hoorn 48

Houston 27, 250, 256

Hout, Salomon van der 96-97

Hudig, Dirk 111

Hutt, W.H. 14

Imgenbroich 60

Imle, Fanny 19, 188

Indiana 144

Industriebond FNV 256

International Cigar-makers' Union 96-97

International Federation of Christian Trade Unions 29

International Federation of Ship, Dock, and River Workers (IFSDRW) 28
International Federation of Trade Unions 29 International Labour Organization (ILO) 24, 29,242

International Labour Union (ILU) 97

International Monetary Fund 24

International Service Systems (ISS) 240, 246, 249, 251-252, 254, 267

International Transport Federation (ITF) 28

International Working Men's Association

69-71, 80, 97, 100, 108, 143

Internationale Arbeidersvereeniging 108

Internationale Sigarenmakers- en Tabakbewerkersbond 96

Internationale Verstellers-Vereeniging 159

Intersyndicale du Bassin de Charleroi 155

Iron Shipbuilders' Society 181

Ironworkers' Union 135

Italy $83,178,244,257$

Italy, Northern 176

Jemappes 147

Jülich 36,54

Jumet 147

Kalleberg, Arne 24

Kampen 85

Kaplan, Steven 170

Kerkrade 27, 200-202, 205, 207, 209, 211, 213-214, $217,220,222,230$

Kloosterboer, Dirk 256

Knights of Labor $28,100,105,138,143,145,164$

Kohlscheid 27, 201, 226

Kristiana 73

Kuiper, Bert 254

Lafontaine, Jean-Joseph $5^{8}$

Lasalle, Ferdinand 14

Laurel, Ferdinand 82

Lebrun, Pierre 50

Leclerc, Jean $5^{8}$

Leeds 42,65

Lefèbvre, Virgile 154

Leiden 21, 27, 31, 38, 40, 43-45, 48-49, 65, 92, 97

Leipzig $60,80,85,87-89,93,98$

Lejeune, Jean 36-37

Lenger, Friedrich 101-102, 110, 132, 144

Lerner, Stephen 249, 267

Leßner, Friedrich 73

Liebknecht, Wilhelm 80, 93

Liège $35-38,40,49-50,52,57-58,92,96,217,222$

Limburg 36-38, 49, 57, 197, 199, 202-203, 205-207, 209, 214-215, 221, 223, 227, 230, 232

Limburg, South 198, 209-210

Linden, Marcel van der 27-29, 33, 70-71

Liquor Hospitality and Miscellaneous Union (LHMU) 251-252

Lis, Rina 35, 43-44

Liverpool $83,92,182$

Loach, Ken 241, 243, 256 
Local Assembly 300 (LA 300) 138, 141-143, $145^{-146,149,164}$

Lock, Judy 254, 257, 267

Lodelinsart 147

Logue, John 27-29

London $15,27,43,70,72-74,76,80,84-88,90$, 92, 94-100, 152, 158, 195, 238, 241, 251, 253, 256, 261, 266

Lorrant, Arthur 147

Los Angeles (LA) 27, 241, 246, 251, 256, 261

Luciani, Jean 193

Ludwig, Wilhelm 61-62

Lutterade 217

Lyddon, Dave 18

Maastricht 33, 36, 61, 210-211, 220-223, 233

Maastricht Faculty of Arts and Social Sciences 33

Malfregeot, Louis 147

Malfregeot, Phil 147

Mannheim 87

Mannington 144

Mansfield, Malcolm 188, 195

Mariemont 147

Marion 144

Martens, Mari 256, 267-268

Marx, Karl 14, 16, 41, 64, 73-74, 89, 273

Matthews 144

Maurits, State mine 200

Mayhew, Henry 85-86, 98

Metz 76, 93

Meyer, Ron 239, 258

Miami 253

Milkman, Ruth 248, 266

Mill, John Stuart 11, 15-16, 272

Monschau 36, 38, 40, 42, 49, 54, 58-59, 61, 67

Montjoie 36

Morocco 257

Moss, Bernard 102-103, 144

Mulhouse 190

Mutuelle des maîtres-verriers 153

Nationaal Arbeids Secretariaat (NAS) 117, 122 National Society of Amalgamated Brass Workers 182

National Window Glass Workers' Union $145^{-147}, 151$

Nederlandsch Verbond van Vakvereenigingen (NVV) 122, 160, 199-200

Nederlandsch Werklieden-Verbond 108

Nederlandsche Diamantbewerkers-Vereeniging 159-16o

Nederlandsche Roomsch-Katholieke Mijnwerkers Bond 231

Nederlandsche Sigarenmakers Bond 92

Nederlandse Timmerliedenbond 115

Netherlands, the $25,27,31,33,40,42,44,46,48$, $58,76,83,87,90-93,99-101,106-108,110,122$, $167,171,174,178$, 190-191, 197-198, 200-202,
206-207, 209, 216, 223-227, 232, 237-238, 240-241, 244, 250, 256-258, 261, 265-267

Neuman, F. 95-96

New York 27, 79-80, 82-84, 97

New Zealand 241, 245, 252, 266

Newcastle 94-95

Nieuwe Algemeene Meubelmakers Bond 115

Nieuwenhuis, Ferdinand Domela 114

Nog Tijdig Ontwaakt 115

Nordstern, mine 202

Norway 93, 174, 178, 192

Nouvelle Union Verrière $148,151-153,155,164-165$

NS (Nederlandse Spoorwegen) 260-262

Nuth 210

Oberhausen 209

Onderling Hulpfonds Boekdrukkunst 127

Ontwikkeling door Eendracht 115

Oranje Nassau Mijnen 200, 219, 222

Oslo 73,177

Ottensen 80

Parfitt, Steven 100

Paris 23, 73-75, 158, 169-171, 177-178, 191, 193

Parti Ouvrier Belge 155

Pasture, Patrick 232

Pennsylvania 140, 144

Pittsburgh 27, 138, 143, 149

Poels, mgr. Henri 222-223, 231, 233

Point Marion 144

Polak, Henri 122, 160

Polanyi, Karl 24

Ponton, Léonard de 58

Potharst, J.Th. 112

Profintern 29

Prothero, Iowerth 101, 103

Proudhon, Pierre Joseph 75

Prussia 176

Rancière, Jacques 101

Randall, Adrian 65

Recht voor Allen 109

Red International 29

Regout, family 221

Renard, Victor 19

Renesse $257-258$

Rhodes, Cecil 158

Ridder, Widukind De 31

Rossum, Matthias van 263

Rot, Adriaan 128

Rotterdam 28, 48, 92, 96, 117, 262

Rotterdam Erasmus Medical Centre 262

Ruhr area 201-202, 207, 216

Rule, John 41, 43, 64

Saxony 40, 80, 196

Scandinavia 83,193

Scheibler, Johann Heinrich 59

Schinnen 210 
Schiphol Airport 254, 256, 262, 267

Schleswig-Holstein 175

Scholliers, Etienne 46

Schröder, P.H.A. 110, 115

Scott, Joan 76

Second International 32

Sedan 21, 27, 38, 40, 43-44, 48-49, 52, 54, 56-57, $65^{-66}$

Sennett, Richard 264-265

Service and Food Workers Union (SFWU) 251

Service Employees International Union (SEIU) 237-241, 246-252, 256, 265-267, 276

Silver, Beverly 274

Sittard 210, 217, 223

Smit, Herman 109

Sociaal Democratische Bond (SDB) 110

Sociaal Democratische Typografen Bond 115, 127

Sociaal Democratische Vereeniging (SDV) 110, 113

Social Democratic League 110, 113-115, 118-127, 130-132

Société Anonyme des charbonnages Néerlandais Willem et Sophia 200

Société d'études jourésiennes 32

Société des Charbonnages Réunis Laura et Vereeniging S.A. 200

Société Générale 153

Soly, Hugo 35, 43

Somerset 42

Sorge, Friedrich A. 75

South Africa 156, 158, 275

South Charleston 144

South Korea 275

Sozialdemokratische Arbeiterpartei 80

Spaubeek 210

Spekholzerheide 200

Spitalfields 84,86

St. Helens 142

Staatsmijnen 200, 205, 213, 216

Stam, Eddy 256

Standing, Guy 24, 242

Steam Engine Makers' Society 182

Steel Smelters Union 135

Stein 210

Stockholm 73

Stolberg 60

Strasbourg 76, 93, 189-19o

Strasser, Adolph 82

Stuttgart 190

Sunderland 142

Suriname 257

Sweden $25,83-84,178,192$

Swenson, Peter 19

Switzerland $72-73,83$

Syndicat des Magasiniers Verriers 151, 155

Syndicat des Verreries Mécaniques 155

Tahiri, Khadija 261

Terwinselen 200
Texas $25^{\circ}$

Thiry, Simon $5^{8}$

Thornton, W.T. 15-16

Tijn, Theo van $31-32,161,164$

Toronto $25^{2-253}$

Transport \& General Workers Union (TGWU) 251

Turkey 257

Twente 117

Typographical Association 181-182

UNI Global Union 29, 240, 256, 259, 267

Union des Verreries Mécaniques Belges 153

Union Network International (UNI) 240, 250, 256

Union of Platers' Helpers 135

Uniontown 144

United States (USA) 11-13, 23-24, 27, 33, 73, $78,84-85,87,90,99-100,102,105,132-133$, $136-138,142-144,148-154,162,164-166,237$, 240-241, 245, 249-251, 256-257, 265-266, 271, 274-276

Universal Federation of Window Glass Workers of the World 142-143

University of Alberta 252

University of Amsterdam 244

University of London 253

Utrecht University 31

Utrecht $85,92,97-98$

Vaals $49-50,62,67$

Vandervelde, Emile 148, 154

Varlez, Louis $186-187$

Varoufakis, Yanis 24

Verband der Bergarbeiter Deutschlands 199

Vereeniging tot Nut der Nederlanders 97

Verreries de la Paix 148

Verviers 21, 27, 33, 36, 38, 40-42, 44, 48-50, 52, $54,56-58,61-62,65,94,272$

Vienna University 32

Voor Allen, Door Allen 115

Vooruitgang door Broederschap 109-110

Vooruitgang zij ons Doel 108, 112

Voorzorg en Genoegen 126-127

VU (Free University Amsterdam) 263

Wadauer, Sigrid 32, 173

Wallonia 215

Washington DC 246

Webb, Beatrice and Sidney (Webbs, the) 13-14, $17-21,31,44,135-136,185,272-273$

Welskopp, Thomas 23, 101, 104

Wendel, De 200

Wertwijn, Jan Willem 92-93, 96

Wery, Fernand 147

Wery, Jules 147

West Riding of Yorkshire Power Loom Weavers' Association 183

West Virginia 27, 138, 143-145 
Weston, John 14

Wilhelmina, State mine 200, 213, 219

Wiltshire 21, 42

Window Glass Manufacturers Association 142, 165

Window Glass Workers of America 138, 164-165

Wisconsin 17
Yorkshire $21,41-42$

Zaandam 207

Zimmermann, Bénédicte 194-195

Zwahr, Hartmut 80, 98 